\title{
anales
}

\section{de la universidad}

de alicante.

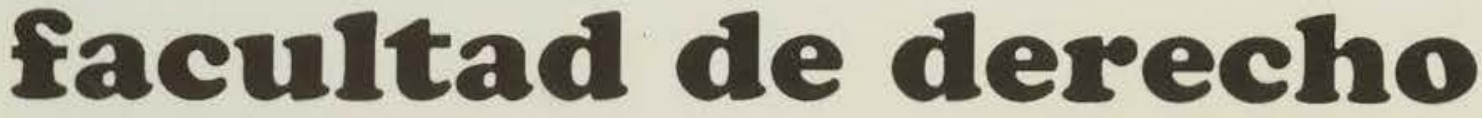

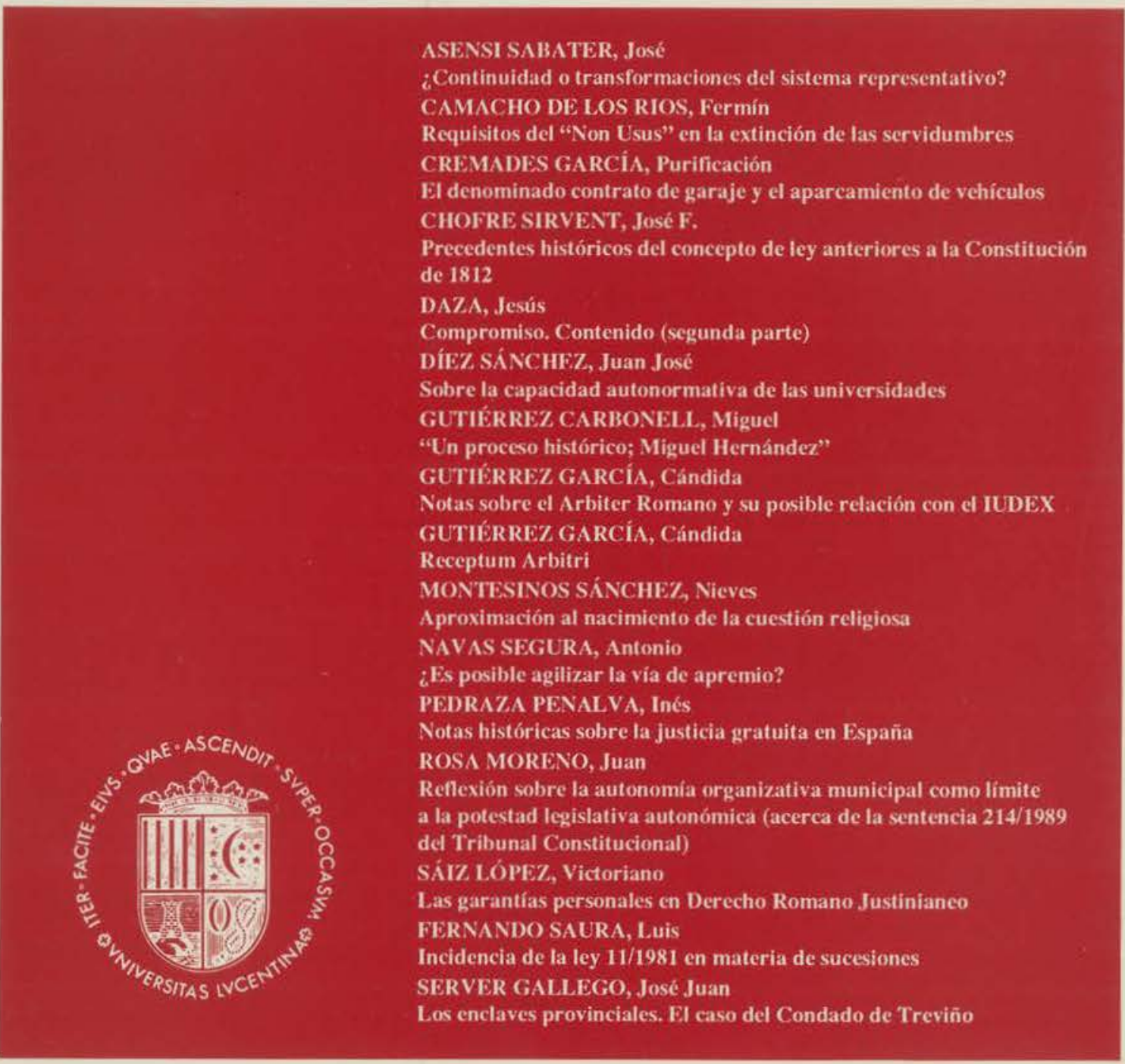

\section{n‥ $6 \quad 1991$}





\section{anales \\ de la universidad \\ de alicante}

facultad de derecho 


\title{
ANALES DE LA \\ FACULTAD DE DERECHO
}

\author{
№. 6 \\ AÑO 1991 \\ CONSEJO DE REDACCION
}

Director D. JOAQUIN MARTINEZ VALLS

Subdirectores D. LUIS FERNANDO SAURA MARTINEZ

D. FERMIN CAMACHO DE LOS RIOS

Vocales

D. MANUEL ALCARAZ RAMOS

D². CANDIDA GUTIERREZ GARCIA

D. CARLOS JIMENEZ PIERNAS

D. JUAN ANTONIO MORENO MARTINEZ

D. MARIA TERESA SOLER REIG

Dํ. CARMEN VIQUEIRA

Secretario

D. JOSE CHOFRE SIRVENT 


\section{anales \\ de la universidad \\ de alicante}

facultad de derecho

ALICANTE 1991 
ASENSI SABATER, José

¿Continuidad o transformaciones del sistema representativo?

CAMACHO DE LOS RIOS, Fermín

Requisitos del "Non Usus" en la extinción de las servidumbres

CREMADES GARCÍA, Purificación

El denominado contrato de garaje y el aparcamiento de vehículos

CHOFRE SIRVENT, José F.

Precedentes históricos del concepto de ley anteriores a la

Constitución de 1812 .

DAZA, Jesús

Compromiso. Contenido (segunda parte)

DÍEZ SÁNCHEZ, Juan José

Sobre la capacidad autonormativa de las universidades

GUTIÉRREZ CARBONELL, Miguel

"Un proceso histórico; Miguel Hernández"

GUTIÉRREZ GARCÍA, Cándida

Notas sobre el Arbiter Romano y su posible relación con el IUDEX

GUTIÉRREZ GARCÍA, Cándida

Receptum Arbitri.

MONTESINOS SÁNCHEZ, Nieves

Aproximación al nacimiento de la cuestión religiosa

NAVAS SEGURA, Antonio

¿Es posible agilizar la vía de apremio?

PEDRAZA PENALVA, Inés

Notas históricas sobre la justicia gratuita en España

ROSA MORENO, Juan

Reflexión sobre la autonomía organizativa municipal como límite

a la potestad legislativa autonómica (acerca de la sentencia 214/1989

del Tribunal Constitucional).

SÁIZ LÓPEZ, Victoriano

Las garantías personales en Derecho Romano Justinianeo

FERNANDO SAURA, Luis

Incidencia de la ley 11/1981 en materia de sucesiones.

SERVER GALLEGO, José Juan

Los enclaves provinciales. El caso del Condado de Treviño 


\section{RESUMENES DE TESIS DOCTORALES}

ALIAGA AGULLÓ, Eva

El Banco de España: Aspectos jurídicos-financieros

IGLESIAS SEQUEIROS, José Luis

Estudios jurídico-sociales sobre los indios Guaymi

MATEO MATEO, Félix

Las crisis bancarias. Los problemas jurídicos que producen y las soluciones del ordenamiento jurídico

MONTESINOS I SÁNCHEZ, Nieves

La confesionalidad, pieza clave en la historia constitucional española $\mathrm{y}$ en el régimen franquista

NAVARRO FAURE, Amparo

"Aspectos jurídicos-financieros del déficit público".

SORIANO SORIANO, José Ramón

Análisis de las agravantes específicas del hurto y del robo con fuerza en las cosas. 


\title{
¿CONTINUIDAD O TRANSFORMACIONES DEL SISTEMA REPRESENTATIVO?
}

\author{
JOSE ASENSI SABATER
}

Universidad de Alicante

Los grandes cambios que están experimentando las organizaciones políticas contemporáneas, transformándose paso a paso en sistemas más amplios de dominación, sitúa en un primer plano la necesidad de una reconsideración de los mecanismos tradicionales de mediación y el papel de los órganos llamados a ejercer la función de legitimación. Es esta una problemática presente hoy en la teoría política y en el Derecho Constitucional, aunque de un modo muy distinto que en el pasado.

Desde la percepción de que asistimos a una "crisis" de los modelos políticos basados en la estructura del Estado y en las fórmulas de Welfare, a la desaparición de barreras ideológicas y en la progresiva interrelación a escala mundial de los espacios económicos, culturales y comunicacionales, la notable paradoja que se produce es que los viajeros esquemas de representación política (representantes, Parlamento, elecciones) se presentan como instituciones que atraviesan una situación de crisis y, al mismo tiempo, contradictoriamente, como uno de los instrumentos más firmes e incontestados en el proceso de recomposición de los sistemas de dominación.

Si por un lado estos esquemas muestran con relativa claridad síntomas de obsolescencia, en forma de desprestigio y desautorización participativa, por otro, la justificación de los sistemas políticos de base representativa no parece representar un problema serio en el contexto de las democracias consolidadas de Occidente, donde los fundamentos jurídicos y los principios representativos, como afirma Hennis, nunca han sido tan poco discutibles como ahora (1).

Al prestigio que ha acompañado tradicionalmente a unos sistema de representación que, en líneas generales, han resistido los más diversos cuestionamientos, algunos de los cuales han sido cuestionamientos frontales, se añade ahora el hecho ejemplar de que esos mismos instrumentos constituyen tal vez el soporte principal sobre el que se trata de basar la reconstrucción de los sistemas políticos de los hasta hace poco llamados Estados de Democracia Popular.

La crítica de las instituciones representativas, en el marco del Estado y en el área cultural europea o europizada, no es, sin embargo, un fenómeno novedoso, sino que puede considerarse consustancial a la evolución de todo el Estado moderno, aunque esa crítica es más aguda en los momentos de crisis; y es justamente en las coyunturas de crisis, cuando los viejos esquemas se ven sustituídos por otros nuevos, si bien de modo aún impreciso, y cuando, por así decirlo, se extiende el sentimiento de inseguridad ante las consecuencias del cambio que toda crisis comporta, es también entonces cuando se producen las respuestas teóricas más contrapuestas. 
Tradicionalmente, las propuestas de reforma de las instituciones representativas, heredadas de la época del liberalismo político, se sitúan, simplificadamente, entre estas dos referencias: la que parte de los propios fundamentos históricos de la representación política, que no es otra que la clásica formulación liberal, postulando se regeneración, y aquélla otra que, en nombre de un nuevo realismo, se plantea una superación definitiva de lo que en estos esquemas pudieran existir todavía de mitificación de la realidad política.

Se podría decir, no obstante, que a pesar de las constantes críticas y revisiones a que ha estado sometido el modelo liberal de representación, como ha recordado Virga, no ha habido en los últimos cincuenta años un verdadero debate que explícitamente haya abordado los cambios que se han ido introduciendo en el modelo representativo heredado de esa tradición liberal-burguesa, pese a que podían identificarse bastantes características que diferenciaban muy claramente los aspectos formales del sistema político y el sistema de representación política de las sociedades capitalistas de los años inmediatamente anteriores y posteriores a la Primera Guerra Mundial con respecto a los existentes en las sociedades anteriores (2).

Estas diferencias, en lo esencial, se referían a aspectos tales como la virtual universalización del sufragio universal, la presencia de partidos de masas organizados, el desarrollo de los organizaciones permanentes de representación de intereses específicos con un nuevo papel institucional, o a las nuevas formas que comenzaba a adoptar la producción legislativa que, a su vez, reflejaba un cambio gradual desde una concepción universalista de las leyes asociada a la edad del liberalismo clásico, hacia una mayor especificidad en el contenido de las leyes y una paulatina delegación del poder en organismos administrativos (3).

Ahora bien, uno de los aspectos significativos que singularizan la crisis actual de los esquemas representativos que presenta el Estado de Bienestar, es el hecho de que se encuentran inexorablemente presionados por las nuevas complejidades sociales, por sectores y grupos sociales, minorías, y grupos que no encuentran en dichos esquemas cauces apropiados o posibilidades de expresión; tal vez podría explicarse esta situación diciendo que la complejidad y fragmentación que presentan los diferentes movimientos sociales es hasta cierto punto incompatible con el proceso hacia la unidad y homogeneidad que de suyo implica el sistema representativo.

Se trata, pues, de una crisis, pero de una crisis que parece afectar a determinados supuestos estructurales en el funcionamiento de los sistemas representativos y que, afecta, si bien no a la totalidad de sus funciones, sí desde luego, y de modo significativo, a algunas de ellas.

No parece, por de pronto, que estemos ante una situación similar a la crisis que padeció el sistema representativo de raiz liberal en los años veinte y treinta: se trataba entonces, como es sabido, de sustituir los clásicos mecanismos liberales de representación individualista y la expresión de éstos en las instituciones parlamentarias, por otros de naturaleza organicista; independientemente de otros fatores históricos e ideológicos, no fue ajena a las críticas radicales procedentes del campo conservador, como demuestran los escritos de Schmitt y la realidad política de la época, la bús- 
queda de un sistema de representación que asegurara la viabilidad de una sociedad sometida a un intenso proceso de industrialización y amenazada por una grave pérdida de identidad (4).

Por el contrario las críticas al sistema representativo que se formulan hoy -en la medida en que, como decíamos, y salvo propuestas residuales, no comprometen las líneas maestras del sistema liberal-democrático, pues sólo este sistema se presenta como garante del soporte legitimador de los sistemas de dominación actuales -tienen un tono distinto a las críticas radicales que se produjeron en Europa en los años treinta: no se presentan, en primer término, como alternativas institucionales; no pretenden una modificación profunda de las reglas principales que regulan el instituto representativo; son críticas, por último, que envuelven el problema de la representación en un discurso más general, fuertemente teñido de componentes neoideológicos, es decir, se conectan directamente con una formas de discurso que, desde pretensiones invitablemente hegemónicas, se presentan como discursos sobre la "sociedad".

Ello no quiere decir en modo alguno que no puedan surgir, o no puedan estar surgiendo, alternativas representativas en las que, de nuevo, se exarcebe la idea identidad nacional, la armonía de la concepción corporativa del mundo o, incluso, el componente de la adscripción religiosa frente al sistema tradicional de representación individual y de organizaciones partidarias; bastará señalar por el momento que estas referencias no parecen estar incluídas entre los principales elementos legitimadores que alimentan los nuevos procesos de dominación; es más, como decíamos, tras el fracaso de los sistemas políticos de inspiración marxista, resplandece aún en mayor medida la solidez de los fundamentos liberal-democráticos de los sistemas representativos, al servir no sólo como instrumento -con toda la carga de evidencia práctica que ello supone- para la recomposición de las organizaciones politicas de estos países, sino como uno de los principales estándares que se exhiben como necesarios para dar credibilidad a la configuración de un pretendido $-\mathrm{y}$, una vez más, "nuevo", orden mundial.

Es por ello que vamos a referirnos a algunos aspectos del debate que se está produciendo en torno a la "crisis" de los sistemas representativos, es decir, a la inadecuación, que no "quiebra", de los instrumentos tradicionales de representación ante lo que denominábamos el proceso creciente de complejidad y fragmentación social de las sociedades actuales, comenzando por señalar someramente los polos más extremos en que se sitúan las alternativas de reforma, pues su delimitación, aún a riesgo de resultar simplificadora y reduccionista, permite contemplar mejor el núcleo de la problemática.

\section{ENTRE EL ARCAISMO Y EL FUTURISMO.}

Tanto hoy, pues, como en el pasado, las respuestas que provienen del campo de la teoría política, ante las deficiencias que presentan las instituciones representativas (pues no hay que olvidar que la idea de que el Estado sufre una constante "crisis de representación", es una idea antigua y ha venido ocupando un lugar central en la reflexión teórica) (5) suelen encontrarse ante una encrucijada con dos polos de fuga opuestos. 
De una parte, se presentan las propuestas arcaizantes, esto es, aquellas que tratan de volver la mirada al pasado, buscando en él no solo una fuente de inspiración sino, sobre todo, el modo de obtener una base segura desde la abordar las complejidades del presente; de otra, la tentación que podríamos considerar como futurista, por emplear también aquí el término acuñado en otro orden de cosas por Toynbee, cuya lógica conduce ante todo a propiciar un cambio radical del estado de cosas existente con una finalidad explícitamente revolucionaria (6).

\section{a) La orientación arcaizante.}

La orientación arcaizante significa, en cierto modo, una vuelta atrás, como una tentativa para volver a uno de aquellos estados más felices que, en los tiempos revueltos, se deploran más agudamente -y quizás se idealizan más ahistóricamentecuando más se alejan. ("iOh, cuanto deseo volver atrás/ y recorrer otra vez la antigua senda!/ para poder alcanzar una vez más aquella llanura/donde dejé primero mi gloriosa comitiva.../algunos hombres aman marchar hacia adelante/pero yo me movería andando hacia atrás"., dirá el poeta inglés Henri Vaughan).

Para algunos, la reforma del Parlamento y del papel de los representantes se ha de orientar hacia el objetivo de la recuperación de estas instituciones en su forma más pura; una forma perdida tal vez en algún punto de su recorrido histórico dificil de precisar, pero donde -se afirma- podría reconocerse su entidad en cuanto que instituciónes que llegaron a expresar una voluntad política dirigida al bien común y servida por una clase de representantes adornados de un hondo sentido de la responsabilidad y seguros en su independencia de cualquier tipo de presiòn.

Sabemos hoy, sin embargo, con relativa claridad, que detrás de esta idea regeneracionista no se esconde en el mejor de los casos sino una ilusión. No sería necesario insistir en que, desde los tiempos de Dicey, no ha cesado el debate sobre la existencia o no de una era específicamente liberal. Los artículos profundamente revisionistas de Brenner (6), entre otros, sobre el laissez faire y el intervencionismo estatal, han supuesto un refuerzo considerable para la tesis, contrastada una y otra vez, de que no ha exitido nunca una edad de oro del "laissez faire", sino más bien una determinada construcción doctrinal que ha disfrutado de considerable influencia.

Sin embargo, como se desprende claramente de las perspectivas neoliberales actuales, la reconstrucción del modelo político que se propone, no pasa por la vigorización del Parlamento o de las instituciones representativas sobre la base de un desarrollo de sus contenidos democráticos, sino, por el contrario, por un sistema basado en la autorresponsabilidad individual y regulado por normas simples que aseguren la libertad de mercado.

b) La tentación futurista.

Por el contrario, la perspectiva futurista, más arriesgada en su formulación, suele contemplar, en general, la disolución forzosa de cuerpos, corporaciones, clases y partidos. Se parte aquí de una crítica radical de las instituciones existentes para pasar a imaginarse un orden nuevo y, en ocasiones, autotrascendente.

Si en otras épocas representó una actitud futurista la postulación de la igualdad 
material entre los hombres, el rechazo a la sociedad burguesa y su expresión parlamentaria y su sustitución por instrumentos participativos basados en la identidad espitirual entre gobernantes y gobernados, o bien lo fue asímismo la propuesta de liquidación de las clases y sus partidos organizados en beneficio de un sistema orgánico-naturalista donde presuntamente se armonizaban los intereses al unirse en el organismo social, hoy, al haberse agotado en cierto modo el ciclo que estas ideologías abrieron, la respuesta futurista viene dada ante todo por una extrapolación de las posibilidades que ofrece la revolución tecnológica en el campo de las organizaciones políticas.

La imagen más extrema de esta orientación es, tal vez, la de la superación de las viejas instituciones parlamentarias y partidiarias, por un espacio continuo de decisiones señalizadas a través de los ordenadores personales (7).

\section{PLURALIDAD SOCIAL Y HOMOGENEIDAD REPRESENTATIVA.}

En medio de estas dos extremas posiciones se encuntra un amplio panorama de propuestas de reforma del sistema representativo que, en lo esencial, se ubican en el respecto a las reglas básicas del sistema democrático-liberal.

La apertura de los sistemas políticos a espacios más amplios, con la debilitación de los vinculos estatales y la pérdida de significado de la soberanía nacional, es una de las consecuencias, y no la principal, de la internacionalización del modo de producción capitalista un una nueva fase de desarrollo y transformación de las sociedades (8). Es este el terreno, a nuestro parecer, donde debiera situarse un debate fructífero sobre los problemas actuales que conllevan los mecanismos de representación y de legitimación políticas.

Por ello parece obligado partir del supuesto de que una buena parte de los grandes problemas que afectan a la organizaciones políticas es este fin de siglo, en la medida en que suponen obstáculos para la realización de los objetivos democráticos, no tienen su solución, si es que existe una solución que dé forma definitiva a las exigencias de participación y control de los ciudadanos en las decisiones que les acectan, en la escala del Estado, del mismo modo que el problema reside ahora, en lo esencial, en cómo establecer garantías para que las decisiones que hayan de adoptarse, y que de hecho se vienen adoptando ya, en esa otra escala supraestatal, estén sometidas a mecanismos de responsabilidad pública y existan cauces adecados de información, participación y control.

Se han alterado, pues, sustancialmente los supuestos sobre los que se sustentaba anteriormente el esquema representativo y, en consecuencia, los fundamentos de su propia legitimación. Pero esta traslación de la problemática representativa hacia formas de dominación más generales, sin embargo, no va acompañada de mecanismos eficaces de control democrático del proceso mismo; quedan en pie los problemas derivados de la adecuación del proceso político-democrático a los sistemas de representación imperantes todavía hoy en el constitucionalismo occidental.

Del mismo modo que muchas de las estructuras políticas, nacidas de la transformación democrática del antiguo esquema liberal, han persistido hasta este fin de 
siglo, y se encuentran ahora sometidas a un intenso proceso de adaptación, así ocurre con los esquemas representativos; el mundo que aflora tras la crisis de los sistemas políticos del Este de Europa, las presiones sociales que delatan, cada vez con mayor intensidad, que las bases sociales de los antiguos estados-naciones sólo pueden considerarse homogéneas madiante un mecanismo de perversión simbólica de la realidad, la fragmentación interna de las sociedades desarrolladas y las distintas posiciones que en ellas ocupan los individuos, todo ello, pone de manifiesto las dificultades de los sistemas representativos para conseguir expresar, por vía legitimación, no solo la pluralidad de la sociedad y la coexistencia en ella de los valores más diversos, (9) sino la propia capacidad de integración en el sistema político, al que aspiró, muy sustancialmente, el mecanismo representativo ideado desde las revoluciones liberales.

De un lado pues, nos encontramos con una extremada fragmentación y pluralidad de lo social que se diversifica y recompone en espacios políticos muy diversos (10); de otro, un sistema que legitima la organización política estatal, a través de mecanismos representativos pensados para funcionar -o, incluso, para contribuir a formar- en sociedades homogéneas, tanto en lo referido a los intereses prioritarios que el propio sistema representativo estaba llamado a expresar, como en lo referido a su funcionalidad acorde con un mundo valorativo relativamente exclusivo.

\section{REPRESENTACION Y LEGITIMACION}

Si este planteamiento, mínimamente esbozado aquí, permitiera una aproximación al centro del problema, sería necesario sin embargo, y antes de proceder al exámen de los elementos de transformación y continuidad de la institución a la luz de la modificación de los contextos de los que opera, centrar la atención en un punto donde los mecanismos representativos se implican en la problemática más general que presentan las organizaciones políticas contemporáneas, esto es, la problemática de la legitimación.

Se ha aludido, con el propósito de explicar la crisis de representación en la que presuntamente nos encontramos, a que ésta no es sino un aspecto de una problemática más global encuadrada en torno a la llamada crisis del Estado Social y más específicamente a la crisis de legitimación vinculada a aquél (11).

En su formulación más genral, se alude a que el proceso de crisis de legitimación se plantea inevitablemente cuando aumenta la desproporción entre las demandas que se plantean al sistema, cada vez mayores en número y heterogeneidad, y la capacidad limitada que tiene el sistema público para satisfacerlas. La lógica consecuencia, entre otras, de esta contradicción es el deterioro de la institución representativa que es, entre las instituciones del Estado, la que aporta mayor dosis de legitimación al sistema.

Asistiríamos, pues, a una crisis de legitimación del Parlamento y a un cuestionamiento desde todos las ángulos del papel de los representantes políticos (12). Ahora bien, no se trata, desde esta perspectiva, de anunciar una nueva versión de la crisis de la institución parlamentaria, como consecuencia de su pérdida de influen- 
cia relativa respecto a otros poderes del Estado y otras instancias públicas o semipúblicas. Se trata, como ha indicado Labriola (13), por el contrario, y como nuevo dato característico de la crisis del Welfare State, de un debilitamiento general de las instituciones de la democracia representativa, que afecta de un modo similar y solidario al Parlamento, al Gobierno y a la Administración y que, más allá, afecta también al funcionamiento tradicional del sistema de Partidos Políticos.

No estaríamos, pues, ante el supuesto de tratar de recuperar para el Parlamento un poder que le ha sido arrebatado por el Gobierno, pues este poder o autoridad ya no está depositado en aquél sino que ha ido a parar a otros ámbitos subinstitucionales, sino ante el problema de cómo restituir la legitimidad al conjunto de las instituciones públicas.

Sin embargo, esta visión que transfiere la problemática del Parlamento y la representación a la existencia de una crisis profunda de legitimación del sistema del capitalismo avanzado o desarrollado, aunque contiene un fondo de verdad, parece en ciertos aspectos superada, o la menos, en trance de haber entrado en una nueva fase: ampliamente difundida en la década de los años setenta principalmente por $\mathrm{C}$. Offe, J. Habermas y O'connor, partía de la afirmación de que las contradicciones internas del Estado Social terminarían por explotar a darían lugar a nuevas formas de relación entre el Estado y la Sociedad.

Pero los procesos político-sociales de la década de los años ochenta se han separado notablemente de las previsiones en este punto y hasta la propia terminología de crisis de legitimación ha dejado de ser utilizada por estos autores (14). No se ha producido, como demuestran todas las evidencias, al menos con caracteres de rotundidad, una crisis de legitimación definitiva, aunque han cambiado las bases sociopolíticas y estruturales de las sociedades avanzadas y ello de tal modo que, paradógicamente, la penuria y del desempleo producidos por la crisis económica no han erosionado, sino al contrario, han fortalecido en muchos aspectos el reformismo neocapitalista y la democracia parlamentaria.

Por ello, si la problemática de la legitimación ha de subsistir, y a nosotros así nos lo parece, será también aquí como referencia a procesos de dominación más generales. A partir de la internacionalización de los problemas políticos y la evidente inevitabilidad de la transición hacia formas de mediación más complejas, hemos entrado en una nueva época de grandes espacios inperiales para los que, hasta ahora, como ha señalado Hennis, no se ha conseguido desarrollar en la Historia una forma legitimable de dominación (15).

Las consecuencias de todo ello en el orden representativo, que como tales pueden apreciarse en los mecanismos jurídicos y en la institucionalización de las reglas constitucionales, son relativamente conocidas. En síntesis, puede decirse que el problema principal es el siguiente: Por un lado se constata la persitencia institucional de las reglas representativas, consagradas constitucionalmente, que en lo esencial, corresponden a reglas derivadas del modelo liberal-burgués de representación; por otro, se constata la existencia de nuevos espacios político-representativos como consecuencia de las necesidades de los procesos de dominación contemporáneos que 
afectan ahora tanto a las funciónes subjetivas de los representantes políticos como a las funciónes objetivas del sistema representativo en sí mismo considerado.

\section{REPRESENTACION Y UNIDAD POLITICA.}

Hay en la tradición filosófica occidental la tendencia a explicar la política con conceptos que provocan una concepción unitaria de la sociedad. Tal vez esa una tendencia dificilmente evitable. Después de todo el viejo discurso de Hobbes se introduce una y otra vez, y más si cabe cuando se trata de teorizar sobre los procesos de dominación.

El problema se plantea cuando esas conceptualizaciones ya no reflejan las características esenciales de los procesos políticos vigentes o no tienen en cuenta los estados de diversificación que se introducen en las sociedades complejas de nuestros días.

Si el desarrollo de los sistemas representativos de raiz francesa ha ido unido al proceso de desarrollo de esa forma de Estado, desde la idea de unidad de la Nación expresada por o en el Parlamento, es de todo punto natural que, en su origen, el establecimiento de instrumentos de representación política, lejos de suponer un modo de llevar al centro del sistema la voz de los intereses concretos o parciales de un grupo o estamento, esté presidio inexorablemente por la lógica del conjunto, de la totalidad.

En el mundo estamental, al asegurar el Soberano la unidad política misma, los diversos intereses y rangos concretos tienen acceso al centro del sistema, si bien no con carácter decisivo. Son, por otro lado, intereses claramente identificados porque estaban definidos, como ha señalado Pizzorno, por la propia estructura social (16); a medida que los estamentos fueron perdiendo su poder en favor de la monarquía absoluta, los criterios sufrieron un cambio sustancial: con la sustitución del soberano real por el Soberano Nacional, las partes o los grupos representados ahora en el parlamento, no podían, por propia lógica, querer otra cosa que el interés de la Nación.

No sólo se partirá de una voluntad única que reside en aquélla, sino que el criterio estamental de identificación de intereses fue sustituida por el criterio geográfico. Tal es, en esencia, el supuesto político y la consecuencia doctrinal que se plantea con la revoluciónes liberales.

Lo característico del pensamiento liberal-burgués fue considerar que la sociedad era capaz de convertir los egoísmos privados en intereses comunes, y esos intereses comunes no eran sino expresión de los propios "intereses nacionales" (17).

A la idea de Nación como sujeto de la Soberanía, en lugar de la vieja noción de la Soberanía del monarca, corresponde ahora una determinada concepción jurídica, en virtud de la cual, y en su clásica formulación, no son los ciudadanos los directamente representados en el sistema político sino la Nación misma que, si bien no puede decidir por sí sola, puede sin embargo actuar por medio de representantes (18). El poder, como se ha dicho expresivamente, cambió de aspecto, no de naturaleza, en 1789 (19). 
Ciertamente que el principio representativo, entendido ahora ya no como "representación ante el poder", a la vieja manera del Parlamento Inglés, sino como exigencia de que el poder político mismo fuera "representativo" originó, como se sabe, un conjunto de extraordinarias consecuencias: alimentó una nueva cultura política, generó una serie de nuevos mecanismos constitucionales, inspiró una nueva forma de entender las relaciones entre Poder y la Sociedad mediante el establecimiento de instituciones de control, contribuyó a deslegitimar en cierta medida la abstracta razón de Estado, y permitió introducir en el Estado, progresivamente, a nuevos grupos sociales que fueron conquistando madurez política y fuerza organizatoria (20). Pero nunca como ahora el principio de representación había dotado al Estado del fundamento ideológico y de los mecanismos legales que permitieran desarrollar todas sus potencialidades.

Sin embargo, desde la ruptura de los supuestos representativos heredados de las revoluciones burguesas, cuyo modelo más conspicuo viene dado por la Contitución francesa de 1791, que se produjo en el transcurso del siglo XIX como consecuencia del movimiento de democratización, con la aparición de la delimitación de clases y los partidos políticos de masas, el fundamento de la unidad (unidad social en torno al tercer estado, unidad espiritual expresada en el ideal de la Nación, unidad política en el Estado) sobre la que descansaba el esquema representativo burgués quedó roto definitivamente.

Como ha escrito De Vega (21), la imagen de la sociedad como un todo homogéneo donde existen intereses comunes se sustituye por una versión hobbesiana de confrontación y de lucha entre intereses irreconciliables:

"... cuando la idea de pueblo y de Nación como unidad se rompe, y cuando surgen intereses sociales antagónicos, no hay ninguna razón para privar a ningún grupo del derecho de sufragio en nombre de una unidad o de un interés común que no existe...".

La fragmentación de la unidad política, sobre la base de una homogeneización ideal de la sociedad, y bajo el predominio de valores burgueses, no sólo se ve potenciada por la aparición de los partidos de clase y la escisión que éstos expresan de una sociedad dividida social e ideológicamente, sino que, más adelante, se ve confirmada por el desarrollo de sociedades que, ex novo, como la americana, se fundan en valores no homogéneos sino fuertemente pluralizados por todo un conjunto de factores (religiosos, lingüísticos, étnicos, territoriales, de diversidad de intereses) que inauguran un modelo representativo bastante diferente del desarrollado a partir de las clásicas definiciones difundidas a partir de los postulados representativos del Estado -Nación que vieron la luz en la época de la Gran Revolución.

La fragmentación de la unidad de sociedad, como un todo homogéneo que, como tal, puede ser representada es, desde entonces, un proceso que no se ha interrumpido, sino que se ha extendido e intensificado. Los supuestos desde los que se puede hablar del Estado Social, como modelo político más o menos difundido a partir de la segunda guerra mundial, partía también de una diversificación y pluralidad de los diferentes intereses sociales, sobre la base de un compromiso, pero que alte- 
raba sustancialmente los mecanismos tradicionales de representación y mediación en beneficio de prácticas corporativas comunmente admitidas y circuitos de representación política paralelos o complementarios a los consagrados en las normas constitucionales (22).

Formalmente, sin embargo, la vocación de unidad que el sistema del representación comporta obliga, constantemente, a recomponer el sentido de esta función objetiva y ello tanto más cuanto la propia fragmentación de los espacios sociales y la pluralidad de identificaciones hacen más frágil y compleja la toma de decisiones. En este punto, diversificación social y de intereses, gobernabilidad y decisión autoritaria del Estado y sistema de representación se implican.

Tan decisiva resulta da idea de hacer residir en una matriz única o unitaria el fundamento representativo del Estado moderno que los intentos por reconstruirla no han cesado hasta nuestros días. Ya desde Hobbes, es la unidad del mandatario, no la unidad de los representantes "lo que hace a la persona una". Este fundamento, firmemente anclado en la noción de "unidad de lo representado", se presentará a lo largo de la evolución de la doctrina política bajo diferentes versiones: "la razón general del todo", proclamada por Burke, la idea del pueblo "como un todo unificado por un interés", expuesta por Bentham y los utilitaristas, la versión francesa de la Soberanía Nacional, elaborada por Sieyés, donde la Nación se presenta como "un todo unido", o bien, más adelante, en las formulaciones de Schmitt, Leibholz o Triepel (el pueblo no puede ser representado en su unidad natural, aunque sí en su unidad política), Bluntschi o Klüber, para quienes el moderno sistema representativo se engendra en al unidad del pueblo considerdo en su conjunto, en una línea que llega hasta Heller, para quien el concepto de representación es fundamental en la constitución jurídica del Estado porque es el instrumento que permite la reducción de la pluralidad social y la conversión de ésta en la unidad de acción y decisión.

En definitiva, el pensamiento del sistema representativo en la democracia es, ni más ni menos, como recuerda Leibholz, el de asegurar de este modo la soberanía del pueblo, como unidad, sobre el pueblo como multiplicidad, como muchedumbre o multitud.

En contraste con estos esfuerzos, que se derivan de la propia lógica que preside el supuesto representativo, la Historia Política de la Europa Occidental desde el último tercio del Siglo pasado hasta la época posterior a la Segunda Guerra Mundial muestra con una gran claridad cómo los conflictos de clase se han expresado muchas veces al margen de los sistemas de representación, mientras que en otras ocasiones se han canalizado por medio de éstos, pero, en todo caso, muestran la descomposición de esta ideología esencialista basada en el supuesto de la existencia de un ideal común en una sociedad de clases, intereses y grupos diferenciados. La evidencia de la naturaleza escindida y contradictoria de la sociedad sobre la que opera el modelo de representación liberal, va a afectar de modo inexoreble a su construcción jurídica: porque sólo desde el supuesto de la unidad de lo representado es posible un determinado tratamiento jurídico, cuando aquél desaparece, el mecanismo representativo se revela, según ya afirmara Kelsen, como una ficción. 
El intento de reconstruir un espacio unitario desde el que fundamentar una teoría de la representación vuelve a reproducirse a partir de los años cincuenta: No se trata sólo de la tendencia "arcaizante" que puede representar, por ejemplo, Hayeck y que da pie, en nombre de la libertad individual, al planteamiento neoconservador dominante en los últimos años, sino también se trata ahora de formular la reunificación de "lo social", no ya mediante la apelación a conceptos esencialistas, como la nación o el pueblo, sino mediante el recurso de partir de la idea de una sociedad conflictiva y pluralista, con intereses diversificados y contradictorios, pero en una suerte de equilibrio y estabilidad basados en el "acuerdo" entre los diferentes intereses sociales.

\section{UNIDAD, LEGITIMACION, RESPONSABILIDAD.}

Estas dos funciones del sistema representativo -la referencia a la unidad y el soporte legitimador que otorga al sistema político- se completan con una tercera función, más oculta, referida al principio de responsabilidad de los representantes, esto es, al hecho de que éstos y las instancias en que se integran hayan de algún modo que responder de su cualidad de tales.

El modo de hacer posible esta responsabilidad en la actuación de los representantes, las articulaciones, en suma, entre las dos instancias de la relación representativa -representados y representantes- ha seguido modelos muy variados; desde un modo de responsabilidad abstracta, como en el discurso de Sièyes, donde los representantes lo son de la Nación, hasta un modo de responsabilidad concreta, como en el supuesto de que los representantes responden de modo directo ante quienes los han elegido, como en el discurso rousseauniano; desde un modelo representativo que tiende a asegurar la autoridad de la decisión política, hasta un modelo que postula la legitimidad previa de la más amplia representación para validar la decisión misma; modelos, en fin que, en sus extremos, pueden suponer desde la disolución del caracter ficticio de la representación respecto a lo representado mediante una total transparencia de los medios, hasta la opacidad total entre los representantes y los representados mediante una ficción estrictamente literal del vínculo que los une.

Ambos extremos no son situaciones imposibles y de hecho se han dado en la praxis de las instituciones representativas. Sin embargo, lo que la evolución de las instituciones representativas revela, a partir de la transformación democrática de los supuestos liberales tradicionales, es precisamente la introducción de mecanismos relacionales, es decir, mecanismos que hacen relativamente operativas las relaciones entre representantes y representados y permiten hablar de un elemento de responsabilidad en la actuación de aquéllos y de mecanismos de control en la esfera de las posibilidades de éstos.

Instituciones tales como las elecciones periódicas y las legislaturas de corta duración, la extensión del sufragio universal, la organización del pluralismo en torno de los partidos políticos, las instituciones complementarias de la democracia directa, los mecanismos interelectorales de control, el papel de los medios de comunicación y la fortaleza de la opinión pública, se han imbricado con las reglas clási- 
cas de la representación política componiendo un complejo desigual, pero introduciendo una estructura relacional que justifica en cierto modo el hablar de un modelo de democracia representativa.

En lo sustancial es este el modelo que ha quedado en pie, una vez invalidados tanto lo sistemas autoritarios que se refieren a un sujeto abstracto de la representación, como los que reivindican un maximun de legitimidad sólo alcanzable mediante la desaparición de toda representación en beneficio de la democracia directa. $\mathrm{Si}$ algo deja claro la evolución de las instituciones democráticas a lo largo de más de siglo y medio es, precisamente, de un lado, el desvelamiento progresivo de los sujetos colectivos y esencialistas, la ruptura de las referencias abstractas y, de otro, la inviabilidad del gobierno directo no solo por su imposibilidad técnica en el orden organizativo, sino por haber quebrado el supuesto de homogeneidad de intereses y el telos ideológico en que se sustenta una concepción del mundo que reclama este principio de organización del poder.

De este modo, los supuestos relacionales de la democracia representativa, aún no habiendo desarrollado todas sus potencialidades, no se refieren a un modelo que suponga un punto intermedio $-\mathrm{y}$ por tanto no dotado de entidad propia- entre los "modelos de decisión" y "los modelos de identidad", sino, a nuestro modo de ver, como el resultado no lineal, sino contradictorio, de prácticas articulatorias entre intereses diversos, pero que, en conjunto, han premitido avanzar en la expresión democrática de esos mismos intereses.

\section{Continuidad y transformación de los supuestos representativos.}

La crisis de la representación política afecta, entonces, a estos tres elementos funcionales que forman la estructura de las instituciones representativas. La crisis de representación es, efectivamente, una crisis de legitimación, en la medida en que la institución no logra obtener el reconocimiento de que la instancia representativa es portadora de intereses concretos y determinados, los cuales puedan corresponderse a las exigencia y en el contexto de una sociedad cada vez más fragmentada; al tiempo, es también una crisis de gobernabilidad, porque por mediación de la representación política no se consigue obtener el consenso suficiente para fundamentar el respecto a la decisión política, puesto que, además, una buena parte de las decisiones políticas de importancia se escapan a las posibilidades de decisión que puedan tener lugar en el orden monocéntrico del Estado.

Es por último, también, una crisis de la estructura de relaciones, mediadas por las instituciones de origen democrático, entre representantes y representados, en el orden de las responsabilidades y los controles respectivos: en este sentido, el cuestionamiento del papel de los partidos políticos, el apartamiento de la participación electoral, el uso pervertido de la apelación al "pueblo", la aparición de movimientos y actitudes al margen de los circuitos democráticos, muestran con toda evidencia el "desbordamiento de lo social" en relación con los cuadros relacionales y organizados de la sociedad.

Las trasformaciones del modelo representativo proceden de una profunda modificación de la realidad social y política de nuestros días. La tentación de resolver 
estas contraposiciones mediante la construcción de modelos fuertemente ideologizados, con pretensiones hegemónicas, para encubrir la carencia de legitimidad y favorecer un orden de decisiones determinado, se hace entonces evidente. La tentación de volver, por el contrario, hacia planteamientos esencialistas, proponiendo nuevas identificaciones colectivas estan bién evidente.representativos ha de paser por una potenciación de sus posibilidades democráticas. La ambigüedad que ha caracterizado a este modelo -que está por otro lado presente a lo largo de su construcción histórica- permite, como ha recordado Agnolli, su utilización como instrumento de progreso y ello aún en mayor medida si se incrementan sus posibilidades relacionales. Por otro lado, el resquebrajamiento de estas instituciones arrastraría inevitablemente los supuestos legitimadores que contiene y el compromiso social de fondo en el que se implica.

Esta dirección marca un programa de renovación de la democracia, una resituación del papel de los partidos políticos, mecanismos más efectivos de ixgencia de responsabilidad y la extensión de los supuestos representativos a otras esferas de la vida social y económica, dando sentido, al fin, al profundo carácter material que la noción de representación potencialmente encierra.

\section{NOTAS}

1.- Wilhelm Hennis, "Legitimät-zu einer kategorie der bürgerlichen Gessellschaft", Duisburg, 1975.

2.- Virga, "Il partito nell'ordinamento giuridico", Milán, 1948. Como es motorio, la problemática de las transformaciones de la democracia ha dado lugar a una amplísima literatura jurídica (Ambrosini, Hula, Adler, Morstein, Marx, Radbruch, Strale, Kaufman) que, desde diferentes perspectivas, han hablado de la existencia de una verdadera mutanción constitucional.

3.- Lowi, Th., "The end of liberalism", N. Y. Norton, 1969. -De Cabo, C. "La crisis del Estado Social", Barcelona, 1986. Para de Cabo, ya durante la etapa del Estado Social se había registrado la crisis de las normas generales y abstractas: "la Ley cuyo sentido en el Estado de Derecho era el de ser garantía de los procesos sociales pasó a ser reguladora específica de los mismos. Dejó de servir como factor de integración social. Si en el Estado Liberal-escribe De Cabo- la ley era el correlato de unas representaciones que se hacían en base a lo que era común a los ciudadanos (salvaguardando lo que les diferenciaba: es decir, la propiedad) y de ahí su generalidad, en el Estado Social la norma se hace instrumento del Estado para la intervención en situaciones específicas". De ahí que se eluda la utilización de la ley a través del mecanismo de la legislación delegada en el ejecutivo, la potenciación de la potestad reglametaria y se produzca el desplazamiento progresivo de competencias a organismos supranacionales. En este último caso, la internacionalización jurídica sigue a la internacionalización del capital.

4.- Amato, G. "forma di estato e forma di governo", en Manuale di Diritto Pubblico, a cura de G. Amato e A. Barbera, Bologna, 1984.

5.- Toynbee, Estudio de la Historia, II, 135 y ss., Barcelona 1984.

6.- Brenner, "Journal of Economic History", 8, 1948. -Un apunte sobre la contrucción del mito de la edad de oro del liberalismo, sumamente interesante, puede encontrarse en Maier, Charles S." Los vínculos ficticio...de la riqueza y de la ley" :sobre la teoría y la práctica de la representación de los intereses, en "La organización de los grupos de interés en Europa Occidental", M. 1988. Para Maier, la agudización de los conflictos de clase desde principios del siglo $\mathrm{XX}$, hizo que los liberales apoyaran y casi siempre idealizaran los partidos de notables de 
mediados del siglo XIX en contraste con la zafiedad y la demagogia que tribuían al "imperialismo populista", tan diferente del juego caballeresco de la política anterior. Estas lamentaciones elegíacas habían -de hecho- empezado mucho antes, hacia 1860 y a finales de siglo se habían transformado en un fuerte sentimiento de desorientación y de pérdida de misión. Vide, Sheeham, S. "german Liberalism in the nineteen Century, 1978. -Withe, Dans S. "National liberalism in the context of european polities", in the splintered Party, 1976.

7.- Pagano, R. "telematica e democrazia diretta", en I.A., 3.

8.- De Cabo, C. "La crisis del estado Social", ob. cit, especialmente el Capítulo dedicado al Estado Social y la periferia capitalista. -Vide Sonntag, M.R. "Hacia una teoría poítica del capitalismo periférico", Madrid 1977,. -J.A. Silva Michelena, "política y bloques de poder; crisis en el sistema mundial", 1984. -J. Petras, "Los estados periféricos: continuidad y cambio en la división del trabajo a escala mundial", en capitalismo, socialismo y crisis mundial", ob. cit.

9.- Laclau, "populist rupture and discourse", Screen Education", 1980.

10.- Offe, C. "Partidos políticos y nuevos movimientos sociales", Madrid 1988.

11.- Eulau, H. "Changing views of representation", en Eulau-Wahlke, 1978. Para Eulau, la incapacidad para dar respuesta teóricas a una realidad que, a pesar de ello, sigue funcionando, es lo que define las características de la crisis de representación política como una crisis "de la idea de representación política". (citado por Rodríguez Ibáñez), "de la crisis de legitimación al corporatismo", en R.C.E.C., 16, 1990.

12.- Loewenberg, G. "modern Parliaments: change or declin?", 1971.

13.- Labriola, S. "La crisis del Parlamento desde la óptica italiana", en Parlamento y Democracia.

14.- Por ahora, la crítica haberniana "insiste promordialmente en defender el mundo de la vida frente al mundo del sistema burocratizado, supuestamente imparcial y activado por los influjos únicos del poder y del dinero. Offe, por su parte, ha atemperado notablemente su radicalismo anticapitalista en su reciente obra "partidos políticos y nuevos movimientos sociales", donde se aboga por una alianza entre la socialdemocracia asistencial y los nuevos movimientos. También las posiciones mantenidas anteriormente por O'connor han sufrido una profunda revisión. O'connor señala que es necesario desprenderse de toda carga de las categorías marxistas tradicionales, legadas a través de las obras de Baran, Sweezy y G. Frank, que siguen dando primacía a los sujetos colectivos sobre los individuos concretos; según O'connor para entender las contradicciones del presente hay que entender y resolver antes las contradicciones de uno mismo. A partir de aquí estructura un discurso que, al decir de algunos críticos, se desliza peligrosamente hacia el subjetivismo personalista, en el que en modo alguno es un pensador original. Vide, Habermas, J. "Teoría de la acción comunicativa", v. II, M 1987, y "escritos políticos", Barcelona, 1988. -Offe, C. ob. cit., O'connor, "The meaning of crisis" Oxford, 1987. -Para un análisis crítico, Pico J. "Teorías sobre el Welfare State", Sistema, 1986.- Rodríguez Ibáñez, "legitimación y conflicto en las sociedades industriales avanzadas", 1987.

15.- Hennis, ob. cit.

16.- Pizzorno, A. "Il sistema pluralista di reppresentanza", 1985.

17.- García Pelayo, M. "Derecho Constitucional Comparado", Madrid, 1987.

18.- Vide Carré de Malberg, "Contribution...".

19.- Chatêlet, F. Pisier-Kouchner, "Las ideologías Políticas del siglo XX", Madrid 1986.

20.- Amato, G. "ob. cit.".

21.- De Vega, "El significado de la Representación Política", en R.E.P.

22.- García Pelayo, M. "transformaciones del Estado Contemporáneo", Madrid, 1986. 


\section{REQUISITOS DEL "NON USUS" EN LA EXTINCION DE LAS SERVIDUMBRES}

FERMIN CAMACHO DE LOS RIOS

Prof. Titular de Derecho Romano

El Derecho Romano, tan acorde en sus principios, hace que las servidumbres se extingan mediante actos jurídicos contrarios a aquellos que generaron su constitución (1), su "bestellung" (2).

Como sabemos, en el ius civile con frecuencia el tanscurso del tiempo puede hacer que alguien adquiera un derecho, pero no que lo pierda. En general el paso del tiempo, la prescripción, no es causa habitual de extinción. Inicialmente las acciones procedentes del ámbito civil no están sujetas a prescripción (3), ni los derechos -aún más los reales- suelen extinguirse por el mero hecho de no ejercitarlos.

En realidad los derechos reales sobre cosa ajena no se pueden perder porque no sean ejercitados, sino indirectamente como consecuencia de que otro, mediante prescripción, adquiera la propiedad de la misma cosa sin gravámenes. Sólo en este sentido la prescripción implica extinción, desde el día en que se ha cumplido, tanto del derecho como de la acción que lo defiende.

En verdad, el no uso (4) de los derechos reales y la prescripción son instituciones bien diferentes (5). El non usus, por vía de la más antigua interpretación de la usucapión, fue admitido como un modo útil para extinguir las servidumbres (6). Cuando la servidumbre no se ejercitaba durante el tiempo indicado para hacer válida la usucapión, el propietario del fundo, una vez que lo había poseido libre de cargas durante dicho plazo temporal, adquiere a través de la usucapión el mismo fundo, pero ahora como libre, extinguiendo la servidumbre.

De aquí que se hable en las servidumbres urbanas de usucapio libertatis, para indicar que el no uso genera el hecho adquisitivo de la libertad de la carga (7).

La servidumbre sólo se pierde como consecuencia de una adquisición; cuando mediante usus se haya adquirido de facto una situación incompatible con un derecho ya existente, que sucumbe frente a la adquisición.

La causa de la extinción no es intrínsecamente el non usus, sino el usus paralelo de la cosa. De nuevo los derechos no se pierden por su falta de uso, sino porque otros los hayan adquirido poseyéndolos.

La prescripción, fruto evidente del derecho pretorio, hace que determinadas acciones puedan ejercitarse sólo en un breve período de tiempo, en general un año para las honorarias, como sabemos, un plazo no dispuesto para el no uso (8).

Fue Teodosio II, en el 424, quien indicó de forma estable el plazo de treinta años para la prescripción de todas las acciones. CT 4, 14, 1 (9):

Sicut in re speciali est, ita ad universitatem ac personales actiones ultra triginta annorum spatium minime protendantur. Sed si qua res 
vel ius aliquod postuletur vel persona qualicumque actione vel persecutione pulsetur, nihilo minus erit agenti triginta annorum praescriptio metuenda: eodem etiam in eius valente persona, qui pignus vel hypothecam non a suo debitore, sed ad alio possidente nititur vindicare.

Justiniano sin embargo, superando la disposición de las XII Tablas que nos indicaba usus auctoritas fundi biennium ceteram rerum annus esto, en C.I. 3, 34,13 (10) sancionó que las servidumbres se extinguen por non usus en el plazo de diez años entre presentes o veinte entre ausentes. Distinción no contemplada en nuestro actual Código Civil (11). Evidentemente la diferencia en la determinación del plazo temporal no es gratuita, y ns pone una vez más de manifiesto la separación entre non usus y prescriptio" (12).

Lo cierto es que en ningún párrafo de la Compilación justinianea se hace la más mínima similitud entre el no uso y la prescripción, ni siquiera de forma implícita. El no uso se configura como un régimen autónomo, sobre el que no influye la teoría general de la prescripción. Se trata de un modo particular de extinción, aún cuando sea asimilable, por los efectos que consuma, a la prescripción extintiva, de forma que las disposiciones relativas a ésta sólo serán aplicables al régimen jurídico del non usus en cuanto sean conformes a la naturaleza propia de los derechos reales a los que afecte.

Con todo, la realidad es que el derecho se perdía por el hecho de que no se usara por un bienio en el Derecho clásico, y por diez años entre presentes o veinte entre ausentes en el Derecho justinianeo, y así nos lo atestiguan las fuentes: Paulo en sus Sentencias III, 6,30 .

Justiniano modificó tal norma estableciendo que el usufructo, sea sobre cosas muebles como inmuebles, se extinguía por non usus en diez años, en dos de sus Qinquaginta Decisiones (C. 3, 33, 16 y C. 3, 34, 13). En otras palabras, Justiniano aplicó a la servidumbre la ordinaria usucapión, que era el fruto de la fusión de la antigua usucapio y de la longi temporis praescriptio (13).

Para que el no uso tenga esa capacidad extintiva es necesario un determinado no uso, cualificado con la concurrencia de determinados requisitos:

I. Debe comprobarse un efectivo no uso, es decir, una falta de ejercicio, por parte del titular del derecho o a quien este haya enajenado o cedido su ejercicio: el adquirente del uso, el donatario, el gestor de negocios, como nos indica D. $7,1,12$, 2 y D. $7,1,12,3$.

2. Usufructuarius vil ipse frui ea re, velalii fruendam concedere, vel locare, vel vendere postest; nam et qui locat, utitur, et qui vendit, donet, puto eum uti, atque ideo retineri usumfructum; et hoc Cassius et Pegasus responderunt, et Pomponius libro quinto ex Sabino porbat. Non solum autem si ego locavero, retineo usumfructum, sed en si alius negotium meum gerens locaverit usumfructum, Iulianus libro trigesimo quinto scripsit, retinere me usumfructum. Quid tamen, si non locavero, sed absente et ignorante me negotium meum gerens utatur quis et ignorante me negotium meum gerens utatur quis et fruatur? Nihilo minus retinero usumfructum. Quod et Pomponius libro quinto probat per hoc, quod negotiorum gestorum actionen acquisivi. 
3. De illo Pomponius dubitat, si fugitivus, in quo meus ususfructus est, stipuletur aliquid ex re mea, vel per traditionem accipiat, an per hoc ipsum, quasi utar, retineam usumfructum? Magisque admittit, retinere; nam saepe, etiamsi praesentibus servis non utamur, tamen usumfructum retinemus, utputa aegrotante servo, vel infante, cuius operae nullae sunt, vel defectae senectutis homine; nam et si agrum aremus, licet tam sterilis sit, ut nullus fructus nascatur, retinemus usumfructum. Iulianus tamen libro trigesimo quinto Digestorum scribit, etiamsi non stipuletur quid servus fugitivus, retineri tamen usumfructum; nam qua retione, inquit, retinetur a proprietario possessio, etiamsi in fuga servus sit, pari ratione etiam ususfructus retinetur.

Las personas a quienes fue cedido el ejercicio no importa que no usen el derecho si la cesión fue onerosa, algo imposible sin embargo cuando fue realizada a título gratuito, como en la donación o el precario.

Si la cesión del derecho fue onerosa, el titular original goza del precio que para él representa el uso; si por el contrario se realizó una cesión a título gratuito, como sería una donación, se necesita el ejercicio del donatario, ya que sin él faltará todo medio para sostener la existencia del uso. Gayo y Muciano son claros en estos matices (D. 7, 1, 38; D. 7, 1, 39; D. 7, 1, 40).

38. Non utitur usufructuarius, si nec ipse utatur, nec nomine eius alius, puta qui emit, vel qui conduxit, vel cui donatus est, vel qui negotium eius gerit. Plane illud interest, quod, si vendidero usumfructum, etiamsi emtor non utatur, videor usumfructum retinere.

39. Quia, qui pretio fruitur, non minus habere intelligitur, quam qui principali re utitur fruitur.

40. Quod si donavero, non alias retineo, nisi ille utatur.

Como confirma también el hecho que si el ejercicio del derecho fue alquilado y el propietario gravado vendía el fundo, el titular de la servidumbre la pierde cuando el adquirente la ejercita a nomine propio, a preguntas de Pomponio responde Ulpiano en D. 7, 4, 29 y 1 :

29. Pomponius quaerit, si fundum a me proprietarius conduxerit, aumque fundum vendiderit Seio non deducto usufructu, an usumfructum per emtorem retineam? Et ait, licet proprieterius mihi pensionem solverit, tamen usumfructum amitti, quia non meo nomine, sed suo fruitus est emtor. Teneri plane mihi ex locato proprietarium, quanti mea interfuit, di factum non esse; quamquam si a me conductum usumfructum quis alii locaverit, retinetur ususfructus; sed si proprietarius eum locasset suo nomine, dicendum amitti, non enim meo nomine fruitur colonus.

1. Non solum usumfructum amitti capitis minutione constat, sed et actionem de usufructu; et parvi refert, utrum iure sis constitutus usufructus, an vero tuitionePraetoris. Proinde traditus quoque usufructus, item in fundo vectigali vel superficie non iure constitutus capitis minutione amittitur. 
A mayor abundamiento, y a tenor de D. 8,6,19, 1, la ignorancia del titular no paralizaba la extinción por non usus, D. $41,3,4,27$ :

27. Si viam habeam per tuum fundum, et tu me ab ea vi expuleris, por longun tempus non utendo amittam vim, quia nec possideri intelligitur ius incorporale, nec de via quis, id est mero iure, detruditur,

A sensu contrario, para la conservación de la servidumbre no resulta necesario que ésta sea ejercitada por el titular, simplemente basta que alguien a él ligado la ejecute, ya sea el poseedor o el simple o el simple arrendatario del ejercicio, como nos recuerdan D. $8,6,5 ;$ D. $8,6,6$; D. $8,6,20$.

5. Servitus et per socium, et fructuarium, et bonae fidei possessorem nobis retinetur;

6. Nam satis est fundi nomine itum esse.

1. Si ego via, quae nobis per vicini fundum debebatur, usus fuero, tu autem constituto tempore cessaveris, an ius tuum amiseris? et e contrario, si vicinus, cui via per nostrum fundum debebatur, per meam partem ierit, egerit, tuam partem ingressus non fuerit, au partem tuam liberaverit? Celsus respondit, si divisus est fundus inter socios regionibus, quod ad survitutem attinet, quae ei fundo debebatur, perinde est, atque si ab initio duobus fundis debita sit; et sibi quisque dominorum usurpat servitutem, sibi non utendo deperdit, nec amplius in ea re causae eorum fundorum miscentur, nec fit ulla iniuria ei, cuius fundus servit, imo si quo melior, quoniam alter dominorum utendo sibi, non toti fundo, proficit.

20. Usu retinetur servitus, quum ipse, cui debetur, utitur, quive in possessione eius est, aut mercenarius, aut hospes, aut medicus, quive ad visitandum dominium venit, vel colonus, aut fructuarius.

II. El no uso debe ser completo. Si el titular de la servidumbre utiliza sólo en parte el derecho, la pérdida que se origina no es de carácter global (14) (D. 7, 1, 5 y D. 7, 4, 25 y 27), a no ser que se afirmara, en el acto de constitución de la srvidumbre, la intención del titular de gozar del objeto por entero y de forma total. D. 7, 4, 20:

20. Is, qui usumfructum habet, si tantum utatur, quia existimet se usum tantum habere, an usumfructum retineat? Et siquidem sciens se usumfructum habere, tantun uti velit, nihilo minus et frui videtur, si vero ignoret, puto eum amittere fructum; non enim ex eo, quod habet, utitur, sed ex eo, quod putavit se habere.

Son numerosos los ejemplos que nos ofrecen las fuentes para denotar el carácter extintivo del non usus parcial; en D. $8,3,18$ pr., cuando una servidumbre afecta a más de un fundo, si no se ejercita en uno de ellos, durante un plazo similar al dispuesto para la prescripción, la servidumbre se mantiene activa y latente en todos los demás fundos; al igual que si sólo se ejercitan algunas de las facultades atribuidas a la servidumbre es suficiente para no invalidar las restantes (D. 8,6,2).

En esta línea también se orienta la redacción de nuestro Código Civil en su art. 548 , el supuesto de una titularidad comunitaria en una servidumbre, "si el predio 
dominante perteneciere a varios en común, el uso de la servidumbre hecho por uno impide la prescripción respecto de los demás".

Caso distinto es que la causa del non usus sea porque la servidumbre es ejercitada en modo distinto al establecido en su constitución; esta es causa suficiente para su extinción. Son clásicos los ejemplos que nos ofrecen el D. 8, 6, 10 y D. 8, 6, 18 (15).

10. Si commune, fundum ego et pupillus haberemus, licet uterque non uteretur, tamen propter pupillum et ego viam retineo.

$S i$ is, qui nocturnam aquam habet, interdiu per constitutum ad amissionem tempus usus fuerit, amisit nocturnam servitutem, qua usus non est. Idem est in eo, qui certis horis aquaeductum habens aliis usus fuerit, nec ulla parte eaurm horarum.

18. Si quis alia aqua usus fuerit, quam de qua in servitute imponenda actum est, servitus amittitur.

Mucius Scaevola no deja dudas, para el jurista es clara la distinción entre la prescripción de la servidumbre (titularidad del derecho) y de la forma (modo diverso de ejercitarla), en el primer supuesto existe un no uso del derecho y en el segundo una irregularidad en la forma de uso.

En nuestro derecho actual "la forma respecto de la servidumbre vale tanto como manera de ejercitarla". Para el Código es clara la distinción entre la prescripción de la servidumbre (titularidad del derecho) y de la forma (modo de ejercitarla), en el primer supuesto existe un no uso del derecho y en segundo una irregularidad cualitativa en la forma de uso.

III. El no uso debe ser imputable y voluntario. Debe ser una renuncia autónoma. Será Ulpiano en D. 27, 9, 3, 5 y D. 7, 1, 12, 3 quien nos precise este matiz.

3. De illo Pomponius dubitat, si fugitivus, in quo meus ususfructus est, stipuletur aliquid es re mea, vel per traditionem accipiat, an per hoc ipsum, quasi utar, retineam usumfructum? Magisque admittit, retinere; nam saepe, etiamsi praesentibus servis non utamur, tamen usumfructum retinemus, utputa aegrotante servo, vel infante, cuius operae nullae sunt, vel defectae senectutis homine; nam et si agrum aremus, licet tam sterilis sit, ut nullus fructus nascatur, retinemus usumfructum. Iulianus tamen libro trigesimo quinto Digestorum scribit, etiamsi tamen usumfructum; nam qua ratione, inquit, retinetur a proprietario possessio, etiamsi in fuga servus sit, pari ratione etiam ususfructus retinetur.

5. Nec ususfructus alienari postest, etsi solus fuit ususfructus pupiIli. An ergo hic nec non utendo amittatur, si tutor causam praebuerit huius rei? Et manifestum est, restaurari debere. Sed si proprietatem habeat pupillus, non potest usumfructum vel usum alienare, quamvis Oratio nihil de usufructu loquatur. Simili modo dici potest, nec servitutem imponi posse fundo pupilli vel adolescentis, nec servitutem remitti; quod et in fundo dotali placuit.

En el primer texto se indica que no se pierde la servidumbre si no se puede usar 
de facto del siervo que era objeto del usufructo, a causa de su huida, enfermedad o simplemente por viejo o infante. Mientras que el segundo, en atención a la oración de Settimio Severo del 195 que limitaba la facultad de vender los bienes del pupilo por el tutor, se indica que de forma análoga el pupilo no pierde la titularidad de la servidumbre que su tutor no ejercita en su nombre (16).

Dos ejemplos contundentes de la ineludeble voluntariedad e imputabilidad del no uso en la extinción del derecho.

IV. Debe transcurrir por entero dentro del plazo de tiempo establecido por la Ley. Dos años en el Derecho Clásico a tenor de lo indicado en la Ley de las XII Tablas, y diez o veinte años en Derecho Justinianeo según C. I. 3, 34, 13.

Dos son los problemas que nos plantea este plazo temporal de extinción, el primero se presenta en cuanto a la interrupción del plazo establecido (17). En realidad sólo cabe la interrupción que nace de las peculiaridades intrínsecas del ejercicio de la servidumbre, la denominada interrupción natural (18). Paulo en D. 7, 4, 28 nos autoriza esta excepción:

28. Si usufructus alternis annis legetur, non posse non utendo eum amitti, quia plura sunt legata.

El jurista nos recuerda el supuesto del "usufructus alterius annis constituto" que en razón a la especial peculiaridad de su ejercicio, el derecho no se extingue por non usus, ya que cada año se constituye un usufructo especial.

El otro problema es conocer con exactitud el inicio del plazo extintivo. Para conocer desde qué día se comienza a computar el tiempo del non usus, debemos acudir al fundamento mismo del hecho extintivo, esto es, la paralela posesión que el propietario gravado realiza sobre el objeto de la servidumbre como libre de cargas. Desde que se ha comenzado a poseer el fundo como libre.

Evidentemente se debe considerar el carácter contínuo o discontínuo de la propia servidumbre, en las servidumbres denominadas contínuas el período se inicia desde el último acto de ejercicio, mientras que para las discontínuas desde el día en que el titular pudo ejercitarla y no lo hizo. No se computan los períodos de tiempo en los que la servidumbre no se podía ejercitar. D. $8,6,7$ :

7. Si sic constituta sit aqua, ut vel aestate ducatur tantum, vel uno mense, quaeritur, quemadmodum non utendo amittatur, quia non est continuum tempus, quo, quum uti non potest, non sit usus. Itaque et si alternis fannis vel mensibus quis aquam habeat, duplicato constituto tempore amittitur; idem et de itinere custoditur; si vero alternis diebus, aut die toto, aut tantum nocte, statuto legibus tempore amittitur, quia una servitus est. Nam et si alternis horis, vel una hora quotidie servitutem habeat, Servius scribit, perdere eum non utendo servitutem, quia id, quod habet, quotidianum sit.

Otra cuestión será cuando la naturaleza de la servidumbre es de las llamadas negativas, por una indiscutible analogía, el inicio del cómputo se realizará desde el día en el que se ha verificado un hecho que impida su ejercicio, esto es, desde que el dueño del predio serviente realiza algún acto contrario al contenido mismo de la servidumbre. 
Una muestra más de la evidente influencia del Derecho Romano en nuestro Código Civil viene reflejada en el art. 546 párrafo segundo (19) "Este término principiará a contarse desde el día en que hubiere dejado de usarse la servidumbre respecto a las discontínuas y desde el día en que haya tenido lugar un acto obstativo a la servidumbre respecto a las contínuas" (20).

Sólo una vez que concurren estos cuatro requisitos el non usus, superando la clásica estabilidad que genera el paso del tiempo, se convierte en un modo, aunque indirecto, plenamente eficaz para la extinción de los derechos de servidumbre.

\section{NOTAS}

(1).- Como génesis jurídica en preferible hablar de constitución que de adquisición. Aunque si observamos a la servidumbre como un bien común del tráfico económico, por esa intrínseca adhesión al fundo al que pertenece, puede utilizarse el término adquisición de la servidumbre al hablar de su transmisión.

(2).- El término "bestellung" tiene un significado paralelo a "establissent" y recoge con exactitud el matiz constitutivo.

(3).- La utilización del término y del concepto de prescripción, como forma útil de extinción, crea una ambigüedad en el leguaje aún vigente en nuestros días. Nuestro Código Civil con frecuencia utiliza expresiones distintas para significar un mismo instituto. Por extinción se concluye el usufructo en el art. 513. 7; mientras en el art. 546. $2^{\circ}$ se habla de "no uso". Ver Albaladejo, Instituciones de Derecho Civil, parte general, 1960, pág. 482; Castán Tobeñas, Derecho Civil Común y Foral, parte general I, vol 2, págs. 854-856; y fundamental la monografía "De la prescripción extintiva", de Alas, de Buen y Ramos, Madrid 1918, pág. 87 ss.

(4).- La utilización terminológica de "no uso" es la literal traducción del concepto que se encuentra en las distintas fuentes romanas; en ellas siempre encontramos, al no existir ni el término ni el concepto de prescripción, los términos "non uti" y "non usus" como hecho general extintivo.

(5).- Como nos indica Grosso "Sulla servitú di non concurrenza e sul non uso delle servitú" en "R. Dir. Común" 1949, 2 y Branca "Non uso e prescrizione" en Scritti in onore Ferrini, Milán 1941,1 , págs. 169 y ss.

(6).- Son numerosos los pasajes de las fuentes que nos recuerdan esta particular fuente de extinción:

D. $8,3,18$

D. $8,5,9$

D. $8,6,2-4-6-7$

D. $39,3,17 \mathrm{pr}$.

D. $43,20,1,23$

D. $43,20,1,5,1$

C.I. $3,34,10$

(7).- Através de la distinción que nos ofrece Gayo, recogida en D. 8, 2, 6, en las servidumbres urbanas el mero no uso de la servidumbre no es considerado, a fines de extinción, suficiente si no se encuentra en concurrencia de la usucapio libertatis.

En realidad el non usus y la usucapio libertatis no son institutos muy distintos, sino dos aspectos de un mismo hecho; en el no uso se considera la falta de ejercicio de la servidumbre por parte del titular, y en la usucapio libertatis se centraba la cuestión desde la perspectiva del gravado por la servidumbre. El non usus sería el presupuesto y la usucapio libertatis la consecuencia jurídica. 
(8).- Este límite de tiempo que se indica en la Ley decemviral es también propio de la época clásica como nos atestigua Paulo Sent. X, 17, 1-2.

(9).-Interesante por la correlación entre C.T. 4, 14, 1 y C.I. 7, 39, 3.

3. Sicut in rem speciales, ita de universitate ac personales actiones ultra triginta annorum spatium minime protendantur. Sed si qua res vel ius aliquod postuletur, vel persona qualicunque actione vel persecutione pulsetur, mihilominus erit agenti triginta annorum praescriptio metuenda; eodem etiam in eius valente persona, qui pignus vel hypothecan non a suo debitore, sed ab alio per longum tempus possidente nititur vindicare.

(10).- C. I. 3, 34, 13:

Sicut usumfructum, qui non utendo per biennium in soli rebus, per annale autem tempus in mobilibus vel se moventibus diminuebatur, non passi sumus huiusmodi sustinere compendiosum interitum, sed et ei decenni vel viginti annorum dedimus spatium, ita et in ceteris servitutes non utendo amittantur non biennio, quia tantummodo soli rebus annexae sunt, sed decennio contra praesentes vel viginti annorum spatio contra adsentes, ut sit in omnibus huiusmodi rebus causa similis, differentiis explosis.

(11).- Nuestro C.c. en su art. 537 no observa la distinción dentro de la usucapión entre presentes y ausentes, seguramente por influencia del 546 (influenciado por el 1073 C.c. italiano) -que abunda en lo ya indicado por el 537-, intentando evitar que a "sensu contrario" el no uso por 10 ó 20 años hiciera generar una servidumbre. Algo, sin embargo, perfectamente factible a través del instituto de la quasi possessio iuris, en este sentido Fermín Camacho de Los Rios, "Supestos de quasi possessio iuris", Granada Serie Maior, págs. 215 y ss.

(12).- Incluso dentro de la pandectística se mantiene la distinción entre non usus y prescripción, como comprobamos en Windscheid Pandette 1, 2 págs. 309 y ss., así como 426 ss. que nos informan de dos institutos diversos "Verjailhrung" y "Auspruch".

(13).- Grosso, "Sull le genesi storica della estinzione delle servitú per non uso" en Faro it. 1937,4 , págs. 266 y ss.

(14).- Sólo una excepción a esta imposibilidad de extinción por non usus parcial, la indicada por Paulo en D. 8, 4, 6:

Iter sepluchro debitum non utendo nunquam amittitus.

(15).- Biondi Biondo "La servitú prediali nel diritto romano", Milán 1969, pág. 322.

(16).- También se opina en contra, apoyandose en D. 43, 16, 10 donde Gayo indicaba que solamente expulsado por los propietarios, el usufructuario tiene derecho a proceder por el daño. Análogamente indica Biondi que se consuma la perdida aún cuando el non usus nazca de impedimento violento del propietario del fundo sirviente, a tenor de su particular interpretación de D. 41, $3,4,26$.

(17).- Amelotti, "La prescrizione delle azioni in dir. rom", Milán 1958, 211 y ss.

(18).- En atención al C.I. 7, 40, 2, debemos considerar que en el Derecho justinianeo se considera válida la interrupción civil, generada mediante acción o denuncia judicial relativa a la propia servidumbre.

(19).- Este inicio del período extintivo también se encuentra recogido con una patente influencia romanística en la Ley 406 de la Compilación Navarra, donde también se habla de acto obstativo, pero con referencia a las servidumbres negativas, así como la Compilación Catalana en su art. 344.

(20).- Auque nuestro Código recoge los supuestos de servidumbres contínuas y discontínuas nada dice de las servidumbres negativas. 


\title{
EL DENOMINADO CONTRATO DE GARAJE Y EL APARCAMIENTO DE VEHICULOS
}

\author{
PURIFICACION CREMADES GARCIA
}

Colaboradora Honorífica Area Derecho Civil

\begin{abstract}
Al amparo del principio de libertad de contratación que inspira nuestro Derecho de obligaciones han surgido en la práctica contratos cuyas cláusulas obligacionales no resultan claras, es especial si se trata de contratos verbales, y que sin embargo se dan en el quehacer diario. Efectivamente, sólo cuando surge alguna duda referente a las obligaciones de una de las partes es cuando se plantea la verdadera naturaleza jurídica de dichos contratos. La doctrina tradicionalmente los ha venido denominando atípicos o mixtos, según que considerase que no tenían su reflejo en ninguna de las formas contractuales que aparecen tipificadas en el Código Civil, o bien si resultaban de la combinación de dos o más de estas figuras.
\end{abstract}

Riera Aisa (1) cita como figuras de contratos innominados -o atípicos que es el tecnicismo que va prevaleciendo para poder incluir así no sólo a los contratos que no tienen un nomen iuris sino además a los faltos de individualidad y reglamentación legal-, y que según él tienen cierto aspecto de generalidad y frecuencia, aparte de los que puedan nacer al calor de la voluntad y libre determinación de las partes, los siguientes: "los de hospedaje, pensión, exposición, deportivos, de asistencia o espectáculos públicos, garaje, educación, cinematográficos, de representación de obras teatrales, de publicidad, de circo o riesgo, de claque, de transporte en coche cama, de croceira o cruceros marítimos o terrestres o forfait, etc".

La doctrina científica registra entre alguno de dichos contratos, atípicos o mixtos, al denominado de garaje, entendiendo como tal a áquel por el que el propietario del automóvil concierta dejar su vehículo mediante remuneración en los locales que a este efecto le cede el garajista. La discusión surge en torno a si este contrato constituye un arrendamiento de cosas, un verdadero depósito, o bien un contrato atípico. Así lo delimita la Sentencia de la AP Madrid de 3 de Octubre de 1987: "El contrato de garaje es una convención atípica, surgida en el presente siglo como consecuencia de las necesidades de la vida moderna, que participa de los caracteres del contrato de arrendamiento de bienes inmuebles, del de servicios y del de depósito, pues el individual es únicamente un contrato de arrendamiento de cosa inmueble".

El sustrato último del problema que aquí se plantea radica en la misma naturaleza y régimen de los contratos mixtos, en el análisis de la norma jurídica que debe regularlos. Cabe señalar como teorias principales y contrapuestas en esta materia la tradicional o de la absorción que estima que se debe descubrir en los contratos mixtos la prestación o elemento principal que domine la totalidad del negocio y le imprima su carácter, y la de la combinación (iniciada por Hoeniger), según la cual deben combinarse las diversas prestaciones correspondientes a los diferentes contratos típicos que integran ese determinado contrato mixto. Sin embargo estudios 
recientes ponen de manifiesto que una y otra teoría son insuficientes para resolver los complejos casos que puede ofrecer la realidad. A juicio de Fubini (2) sólo la intención de las partes que ha constituído el contrato complejo puede dar un criterio positivo para resolver las dificultades y dudas que puedan surgir. Y será el examen de la convención originada el que decidirá de la posibilidad o no de afirmar si el fín perseguido por las partes puede ser alcanzado con un contrato nominado al cual se agreguen otras prestaciones impropiamente llamadas accesorías.

Roca Juan (3) mantiene que hay absorción cuando se pueda averiguar cual de las prestaciones constituyentes de su contenido es principal y cual accesorio, y combinación en cuanto se debe procurar la conciliación de la otras prestaciones con la que es absorbente y la aplicación de los principios generales en materia de obligaciones y procedimiento analógico y consideraciones de equidad como únicos medios de llenar lagunas legales que en cualquier caso, han de producirse si no hay una especial normativa consuetudinaría previamente reconocida.

Siguiendo a Enneccerus (4) podemos afirmar que "la solución compete siempre en última instancia al arbitrio judicial, atendiendo a las circunstancias del caso concreto, especialmente inspirandose en el fín económico y en los legítimos intereses de las partes".

Es por ello que no podemos encuadrar de forma taxativa al contrato de garaje dentro, o bien del contrato de arrendamiento, o bien dentro del contrato de depósito, y la única posibilidad que nos queda es determinar unas pautas previamente para saber si debe prevalecer uno u otro contrato, sin perjuicio de que la Autoridad Judicial considere que, atendiendo fundamentalmente al caso concreto, las consecuencias derivadas de unas determinadas notas en la relación jurídica pueden conrresponder bien a up tipo de contrato o a otro, o bien que el contrato de garaje participe de ambas figuras a la vez.

Según Roca Juan (5) se dice que puede calificarse de arrendamiento de cosas si el vehículo queda en un box, o aparcamiento cerrado, aun dentro de un local colectivo, y de depósito si el vehículo se queda abierto en un lugar colectivo sin reserva de plaza. Se aduce frente a la calificación como depósito, que el contrato que permite el uso continuado (retirar el vehículo y volverlo a dejar) es incompatible con el depósito, a no ser que se constituyan nuevos depósitos cada vez que el coche se deja, tal y como se dijo en la Sentencia de 10 de Junio de 1929. En contra se califica el contrato entre el dueño del vehículo y el propietario del garaje como depósito, partiendo de que el vehículo es cosa mueble que se instaló en el garaje para su custodia y por estimar notorio que el servicio principal de tales establecimientos es la guarda o custodia de vehículos de motor. Poniendo la principal atención en la posible responsabilidad del garajista por los deterioros que pueda sufrir el vehículo y que pueden ser evitados, Roca Juan considera que se ha llegado a una tercera tesis, la del contrato mixto, midiendose la responsabilidad por la genérica del artículo 1.094; contrato que origina una situación que para el garajista se compone de tres obligaciones: recibir el automóvil en el garaje, restituirlo y conservarlo (entrañando esta última la prohibición de utilizarlo), y sin que ello implique obligación de entre- 
tenimiento, salvo pacto especial. Por otra parte el local no es sustituible por otro distinto a áquel donde el vehículo se deja.

En este sentido "Son obligaciones del garajista las de poner un lugar suficiente, determinado o indeterminado, según las peculiares condiciones convenidas, a la disposición del usuario para la ubicación de su vehículo, la vigilancia del mismo y la obligación de devolverlo a su propietario en el mismo estado en que fue entregado, y el incumplimiento de daños y perjuicios en la forma que determinan los arts. $1.101,1.106 \mathrm{Cc}$; sus derechos se limitan a la recepción de la merced convenida y las generales derivadas de las normas de convivencia." (AP Madrid S. 3 Octubre 1987). De dicha Sentencia podemos deducir que los deberes de guarda y custodia o de vigilancia estan incluídos dentro de la diligencia que con carácter general se recoge en el artículo $1.094 \mathrm{Cc}$.

Sin embargo por lo general, tanto ia doctrina, y especialmente la jurisprudencia, han tendido más hacía la consideración del contrato de garaje como un contrato de arrendamiento, eximiendo de esta forma al garajista de la responsabilidad que puede derivarse por la guarda y custodia del vehículo. "No es inherente a los contratos de garaje la necesaria asunción por el dueño de una específica obligación de guarda y custodia; en efecto, es perfectamente imaginable, e incluso es frecuente en la realidad, un contrato de este tipo, en el que el dueño no se obliga más que a entregar la posesión de una parcela del local, con la correspondiente llave, a cambio de un precio cierto y durante un plazo determinado, de tal suerte que la figura contractual que en tal caso surge no es otra que la de un arrendamiento de cosa (art. $1543 \mathrm{Cc}$ ), con las obligaciones que para el arrendador determina el art. $1554 \mathrm{Cc}$., entre las que no figura las de custodia y sí la conservación del local en las condiciones adecuadas y mantener al arrendatario en la posesión pacífica de la cosa arrendada". (AP Bilbao S. 5 Marzo de 1987).

Sentencias más antiguas, como por ejemplo de 10 de Junio de 1929 llegaba incluso más lejos al afirmar que a pesar de tener el garajista el deber de guarda y custodia del automóvil en términos generales, por tratarse de un establecimiento público donde también se encierran otros coches y tienen facultad de entrar libremente sus encargados, esta obligación de vigilancia no desnaturaliza el arrendamiento para convertirlo en depósito de coches, pues a favor de la primera calificación lleva la finalidad del acto, la subsistenciádel contrato despues de sacar el coche para el servicio ordinario del dueño por tiempo indeterminado, y la parvedad y uniformidad de la retribución, tan desproporcionada con los riesgos y obligaciones de que habría de responder el dueño del local si fuese depositario, puesto que el precio es igual para los vehículos de todas las clases y tamaños.

Sin embargo las Sentencias más recientes afirman de forma taxativa la inexistencia de la obligación de guarda y custodia por parte del dueño del garaje. "Ni la buena fe, ni el uso o costumbre, ni la Ley imponen de modo necesario o señalan como de ordinario establecimiento que dentro del contenido obligacional de un contrato de garaje se asuma por el dueño del mismo una específica obligación de guarda y custodia, de tal suerte que ni la aplicación del artículo $1.258 \mathrm{Cc}$ conduce a afirmar como inherente al contrato aquella obligación, ni la aplicación del art. $1.287 \mathrm{Cc}$ 
lleva a afirmar por vía de interpretación, que en caso de ambigüedad tal obligación deba entenderse comprendida en el contenido contractual". (AP Bilbao S. 5 de Marzo de 1987).

"Será sólo la común voluntad de las partes al tiempo de contratar o, en su caso, la lógica deducción que los actos de una debían producir en la otra, la que determine la existencia de una obligación de guarda y custodia por el dueño del garaje y la extensión de ésta; siendo así que ninguno de los datos aportados a la litis muestra que efectivamente fuera voluntad común de los contratantes, como incluída en la oferta y como determinante de la aceptación, la asunción por el dueño del garaje de una obligación de guarda y custodia que se extendiera también a las horas distintas de aquéllas en que estaba prevista la existencia de un guarda, la presencia de éste a unas horas determinadas y la entrega a los usuarios de una llave que les permitiera la entrada y salida fuera de tales horas, en un estado de hecho que, en una deducción lógica, no debía pensar a quien decidiera contratar el uso de una parcela que el garaje se hallaría vigilado y custodiado todo el día, y sí sólo en aquellas horas". (AP Bilbao S. 5 Marzo 1987).

Un dato importante que hasta ahora parecen dar por supuesto las Sentencias mencionadas que eximen al garajista de la obligación de guarda y custodia es que la llave del local se entrega al propietario del vehículo, de esta manera dicho propietario podrá entrar y salir a su entera satisfacción, dificultando a su vez una posible misión por parte del garajista de guarda y custodia, debído a la afluencia de gente que puede poseer una llave y acudir a retirar o dejar su vehículo, entendiendo por tanto que nos encontramos ante un derecho de uso y goce de una cosa, de una parcela de terreno por el que se paga una cantidad ajustada precisamente a ese derecho de goce y disfrute, y que resulta insuficiente si además queremos con ello que se nos contrapreste con la guarda y custodia de nuestro vehículo.

En este sentido la Sentencia de 10 de Mayo de 1989 de la AP Madrid Sección 90: "Se trata de un contrato atípico. Entre las obligaciones del titular del aparcamiento no se halla la de responder de la sustracción, dado lo exiguo del precio satisfecho y el hecho de entregarle a los distintos propietarios de los vehículos una llave del local sin que nadie garantizase la vigilancia y cuidado, existiendo además un cartel que eximiera a la empresa por robo".

Sin embargo, en los últimos años ha surgido una nueva modalidad en el aparcamiento de vehículos, que consiste en dejar el mismo en un lugar cerrado o vallado, sin reserva previa de plaza, y que se paga en virtud de las horas que efectivamente el coche ha permanecido en el mencionado lugar, son los conocidos con el anglicismo de parkings, y se diferencian del antiguo contrato de garaje antes estudiado, entre otros rasgos porque el propietario del vehículo no se queda con la llave del local, sino que éste permanecerá abierto las veinticuatro horas o bien tendrá un horario determinado, pudiendo retirar su vehículo el dueño del coche previo pago de una cantidad que dependerá del número de horas que el vehículo haya permanecido estacionado en el local. Así a la diferencia antes enunciada podemos añadir una segunda y es que no se paga en virtud del espacio ocupado sino del tiempo. Otro 
dato importante a tener en cuenta es que generalmente el vehículo se estaciona cerrado dentro del local.

Así estas tres notas, a saber, no entrega de la llave del local al propietario del vehículo, pago de una contraprestación en función del tiempo que el coche permanece en el local, y no entrega al dueño del local de la llave del vehículo, parece acercarnos más a un verdadero contrato de depósito que a un contrato de arrendamiento, hay intención por parte del propietario del vehículo de entregar éste para su guarda, custodia y posterior devolución. Según el artículo 1,769, cuando la cosa depositada se entrega cerrada y sellada, debe restituirla el depositario de la misma forma y responde de los daños y perjuicios si se cortara el sello o cerradura por su culpa. No cabe duda de que el vehículo se entrega cerrado, y de que de la perpetración de un robo con rompimiento de un cristal del vehículo, puede derivarse una culpa imputable al depositario o garajista si se demuestra que había ausencia total de medios o personas que garantizasen la custodia del vehículo estacionado, existiendo así una presunción iuris tantum contra el depositario en el sentido de tener que demostrar que efectivamente existian los mencionados medios. Dicho precepto esta en íntima conexión con el artículo 1,767 que establece que el depositario no puede servirse de la cosa depositada sin permiso expreso del depositante, o en caso contrario responderá de los daños y perjuicios, obviamente si no se puede utilizar el vehículo objeto del depósito, es por ello que las llaves del mismo no se dejan al garajista.

En cuanto a la falta de entrega de las llaves del local por parte del garajista al propietario del vehículo, resulta el signo más evidente de que no estamos ante un contrato de arrendamiento, ya que no se produce una trasmisión de la posesión del local (o parcela asignada para el estacionamiento), pues según el artículo 1.467 y aunque se trate de una disposición aplicable a los bienes muebles, es costumbre hacerlo en el arrendamiento de inmuebles por cuanto la entrega de llaves posibilita franquear la puerta del local.

En lo referente a la relación que existe entre tiempo o duración, viene a corroborar la existencia de un contrato de depósito, ya que independientemente del tamaño del turismo y por lo tanto del espacio que ocupe, se fija una cantidad que depende del tiempo de permanencia.

Así por lo tanto, si alguna duda podía reportarnos la calificación del garaje entendido en sentido tradicional, es decir, la entrega y permanencia de un vehículo en un local destinado a tal efecto y donde se encuentran otros vehículos de diferentes propietarios, que generalmente poseen una llave del local, quedando en ocasiones su propio vehículo abierto dentro del mismo; sin embargo del devenir de los tiempos ha creado una nueva figura o modalidad, donde el propietario generalmente deja unas horas estacionado su vehículo en el local del garajista, éste permanecerá cerrado y como nota fundamental, el local estará abierto al público, con lo que el propietario del coche no necesitará llave para acceder a recogerlo. Antes, y debido fundamentalmente a la tenencia de la llave del local por parte de cada propietario, hacía que dicha figura se acercase más a un arrendamiento de cosas que a un depósito, y así lo ha considerado la jurisprudencia, eximiendo por lo tanto al garajista de 
la guarda y custodia, y utilizando para ello como hemos visto, diferentes argumentos. Ahora bien, con la nueva figura creada, no cabe duda que nos encontramos en principio ante un contrato de depósito, y que como tal, la obligación fundamental del garajista es la guarda y custodia. Cabe entonces preguntarnos el límite de esta obligación. Analizaremos para ello cuatro temas fundamentales:

En primer lugar el hecho de que la constancia de la entrega suele consignarse en un ticket, al igual que se hace en los guardarropas de los teatros o restaurantes o en las consignas de estaciones o aeropuertos, en estos supuestos en los tickes suele plasmarse un número que ni siquiera existe en algunos tickes de garaje. Así éstos se convierten en la única prueba de la existencia del depósito, prueba que no contiene firma alguna, ni descripción del objeto depositado, ni lugar exacto en que se realiza el estacionamiento, y hasta incluso en ocasions la fecha y hora de entrada del vehículo. El ticket se convierte así en una especie de título al portador, fundada en una presunción de que el poseedor del ticket es aquél que estacionó el coche, pero que en realidad puede o no ser la persona que lo realizó, éste podrá retirar el vehículo a la entrega del resguardo, sin responsabilidad alguna en este sentido por parte del garajista que no tendrá que exigir justificación de la tenencia de dicho resguardo, por lo que no responderá en caso de pérdida del vehículo si logra demostrar que el coche lo entregó previa presentación a su vez del resguardo. Este tampoco contiene la identidad o modelo del vehículo, ni el estado en que se encuentra o el valor de los objetos que pueda contener, con lo que la carga de la prueba en caso de deterioro o robo de los objetos depositados en el interior correrá a cargo del propietario del vehículo (artículo 1.214 C.c.). Ahora bien, la prueba se limitará al estado previo en que se encontraba el vehículo antes de la entrada en el garaje, si resulta evidente que éste se produjo en el interior, por existir señales fidedignas que lo demuestren, por ejemplo restos de cristales en el suelo localizados al lado de donde tiene el vehículo el daño y de los que se deduce que el coche aparcado en ese mismo lado pudo haber colisionado con el primero, entonces la carga de la prueba se invierta y deberá ser el garajista quien demuestre que actuó con la debida diligencia en la guarda y custodia del vehículo. Estaremos en presencia de una situación similar para el caso de robo con fractura de una de las ventanillas del coche por ejemplo; resulta también evidente que los restos de dicha fractura en el suelo y el desorden en el interior del vehículo pueden demostrar por si solos que el robo se produjo en el interior del local, en este caso el garajista tambien responderá de los daños producidos en ausencia de diligencia para la guarda y custodia, sin embargo no podrá responder del valor de los objetos robados ya que previamente no ha habido una identificación de los mismos por parte del propietario del vehículo. Una sentencia reciente de 2 de Abril de 1991 del Juzgado de Primera Instancia $\mathrm{n}^{\mathrm{0}} 31$ de los de Barcelona considera que "la obligación de custodia que prevee el artículo 1769 del Código Civil presume en el párrafo segundo la culpa del depositario y negligencia de la custodia cuando no se devuelve la cosa depositada, y así se desprende de lo actuado, la prueba en contrario no ha sido ni siquiera intentada, la obligación de responder ha de ser una consecuencia necesaria.", por lo que condena a la Empresa garajista a reintregrar no sólo los daños por la rotura de los cristales del vehículo, de lo que en el presente 
caso se hizo cargo de forma voluntaria la mencionada empresa, reconociendo así parte de su responsabilidad como se dice en dicha Sentencia, sino incluso condenando a la misma a pagar al propietario del vehículo el importe del radio-casette que le fue sustraído, ante la ausencia de pruebas que eximiesen a la Empresa de la responsabilidad por su calidad de depositaria. Desconocemos en el presente caso la prueba practicada por el demandante, si bien suponemos que existió por lo menos una mínima actividad probatoria en relación con un modelo determinado de radio-casette, y así calcular su valor concreto, supliendo así la identificación previa a la que aludíamos antes.

Otro problema que se puede plantear es el caso de que se produzca un hurto del vehículo, encontrándose el propietario en la posesión de un resguardo que nada dice de las características del coche que allí depositó, es decir, que al intentar sacar su vehículo del garaje contra entrega del resguardo que le fue facilitado al estacionarlo, el mismo no se encuentra en el local donde lo estacionó. ¿Existiría una presunción de que efectivamente el propietario dejó el vehículo que manifiesta?, pienso que realmente se trata de un problema de difícil solución ya que como hemos dicho en el en el ticket no se plasma el modelo o las características del coche que se estaciona, por lo que resutaría totalmente injusto presumir que la manifestación del usuario del vehículo es la válida, así sería éste último quien tendría que probar que efectivamente el ticket corresponde a la entrada de un determinado vehículo, lo que por otro lado no resulta nada sencillo.

En segundo lugar no debemos olvidar un aspecto de este tipo de contratos que afecta de manera fundamental a su efectividad jurídica. Se trata de contratos verbales, dificilmente podemos considerarlos escritos, ya que a pesar de que en ocasiones las condiciones se plasman en el ticket, éste no podemos valorarlo ni siquiera como un esbozo de contrato, el ticket como tal no deja de ser un mero resguardo acreditativo de un hecho. Otras veces las condiciones se encuentran escritas en grandes rótulos en lugar visible para los usuarios de los vehículos. En cualquier caso las mismas estan impuestas por el garajista y aceptadas tácitamente por el propietario del vehículo, lo que nos aproxima a la existencia de un contrato de adhesión. Resulta evidente que en la confección o redacción de las condiciones contractuales no interviene el propietario del vehículo, fundamentalmente por una razón lógica, la celeridad del tráfico, permitiendo así al garajista formalizar muntitud de contratos en un sólo día. Sin embargo la formalización de este tipo de contratos no llega ni siquiera a poder considerarse como un contrato de adhesión, ya que la vaguedad de sus condiciones resulta aun mayor (6).

Diez Picazo y Gullón (7) consideran dentro de lo que la doctrina alemana llama "Prestaciones de tráfico en masa" la utilización de un aparcamiento de vehículos; éstas se encuadran como una categoría de las "relaciones contractuales de hecho" (4) dicho concepto no es sino un intento de explicar unas relaciones jurídicas similares a las contractuales pero donde falta la necesaria declaración de voluntad; así entre lo que ellos denominan "prestaciones de tráfico en masa" pensemos como ejemplos más evidentes en la utilización por parte de los ciudadanos de un servicio público, con la consecuencia necesaria de tener que pagar una tasa o la propia utili- 
zación de máquinas automáticas. Estamos en presencia de unas relaciones jurídicas en todo iguales -siguiendo a los mencionados autores- a lo que ocurre cuando una persona estaciona su vehículo en un parking, es decir realiza un determinado comportamiento del que nace una obligación, en este caso pagar un precio. Larenz ha hablado en estos casos de una conducta social típica como fuente de obligaciones distinta del negocio jurídico. Diez Picazo y Gullón consideran que querer reducir estas hipótesis a figuras contractuales no pasa de ser una ficción, y que no hay por consiguiente en ellas verdadera relación contractual, pero sí relaciones obligatorias derivadas de una conducta social.

Sin embargo, adimitir dicha postura no soluciona el problema ya que habría entonces que buscar cual es el régimen de dichas prestaciones para llenar esta laguna legal. La única solución posible sería acudir a los principios generales en materia de obligaciones y principios de equidad, y en último término a un procedimineto analógico, lo que nos conduciría inexcusablemente a una figura o figuras cotractuales típicas.

En tercer lugar, la mayoría de los tickes o fustificantes, además de excluir la responsabilidad de la empresa de parking por robo, hurto o daños causados por terceros, incluso en ocasiones llega a afirmar que no se trata de un contrato de depósito el estacionamiento del vehículo, ni de los objetos de su interior. Como ya hemos dicho anteriormente, los objetos que se encuentran en el interior del vehículo no pueden constituirse en depósito ya que en primer lugar éste no es la causa del contrato y en segundo lugar porque falta una identificación previa de los mismos y sus características. Sin embargo en lo referente a la negación de la calificación de este contrato como de depósito, hay que llevar entorno a este extremo un criterio interpretativo siguiendo los principios generales de las obligaciones y los contratos en nuestro Código Civil, debiendo ser los propios Jueces quienes deban ostentar facultades interpretativas y basándose siempre en principios de equidad, teniendo así un poder excepcional, similar al que podría tener en un contrato de adhesión, que les autorice a no aplicar las cláusulas del contrato más que en consideración a la situación particular de las partes, e incluso un poder de revisión que les autorizaría a modificar el contrato en la parte que apareciera como injusta. Podríamos acudir al artículo 1288 y en este caso tendría que sufrir las consecuencias la Empresa de Parking que es la que ha dado lugar a la imprecisión o vaguedad; sin embargo en mi opinión se podría llegar más lejos ya que para interpretar los términos de un contrato según nuestro Código Civil, siguiendo una dirección espiritualista, hay que estar a la intención de los contratantes, con independencia de los términos utilizados; si consideramos que se trata de un contrato en el que existe una parte en la relación cuya voluntad no se exterioriza, habrá que llevar a cabo un proceso lógico para dilucidar cual fue esa voluntad en el momento en que su comportamiento inicial se produjo. Por tanto es fundamental analizar la intención del propietario del vehículo, y ésta sin lugar a dudas es tendente hacia un tratamiento especial hacia su vehículo, una guarda que de no recibirla le sería indiferente estacionarlo en el parking o en la vía pública (8).

En cuarto lugar las responsabilidad del garajista podemos ponerla en relación 
con la del fondista o mesonero. El Código Civil considera también depósito el de los efectos introducidos por los viajeros en las fondas o mesones, sin embargo es requisito imprescindible que previamente el viajero ponga en conocimiento del fondista los objetos depositados (artículo 1783), consideración esta última ya comentada al hablar de los objetos depositados en el interior del vehículo, y es que difícilmente se puede responder de algo que previamente no ha sido identificado, de ahí que como también hemos dicho sería conveniente idear alguna fórmula con la que identificar la marca, matrícula y características generales del vehículo que se estaciona, salvando así un elemento de prueba difícil de superar para ambas partes. En el artículo 1784 se delimita la responsabilidad de los fondistas que no es solamente extensiva a los actos dañosos de los dependientes como lo sería por simple aplicación al Derecho Común, sino también a los actos de los extraños, pero no los que provengan de robo a mano armada o sean ocasionados por otro suceso de fuerza mayor. El precepto parece asimilar la fuerza mayor al robo a mano armada, para excluir este último de forma expresa, sin embargo extiende la responsabilidad no sólo a los daños causados por los dependientes, sino también a los acusados por "extraños"; así por lo tanto a pesar de las diferencias en cuanto a las circunstancias en las que nace el contrato, es decir, que el depósito de los efectos en el contrato de hospedaje se constituiría como accesorio, sin embargo podríamos encontrar un punto de conexión, y es que la responsabilidad se extiende a actos de extraños, lo que por otro lado se entiende con dificultad si excluímos el robo, en especial si se logra probar que había una ausencia total de medios que asegurasen la guarda de los objetos (medidas de seguridad).

Así las necesidades de los tiempos actuales en las ciudades, en especial el aumento del tráfico rodado y la propia inseguridad ciudadana, han hecho que se produzca el surgimiento, paralelo a lo que ya podríamos denominar tradicionales contratos de garaje, otros de aparcamiento de vehículos, cuyas notas relevantes se acercan más a un contrato de depósito que a un arrendamiento, pero que sin embargo necesita de un proceso interpretativo atendiendo fundamentalmente a la ambigüedad casuística que los diferentes supuestos de hecho pueden llegar a producir.

Efectivamente, debido a la ausencia de regulación legal, el Juez necesita en la resolución del caso concreto de un proceso interpretativo atendiendo fundamentalmente a las circunstancias en las que nació la relación, es decir sin la prevía exteriorización de la voluntad por el propietario del vehículo, pero sin que ello impida que por medio de un procedimiento analógico, y previa deducción lógica llegar a la voluntad que subyace en el momento de la entrada en el parking.

Ahora bien aunque sus notas se acerquen más a un contrato de depósito y probablemente dicha interpretación siempre resulte más beneficiosa para el usuario o propietario del vehículo, no podemos ser radicales en dicha afirmación ya que como se ha dicho antes es fundamental el proceso interpretativo del Juez a la vista de la situación concreta y pruebas, y además y aunque sólo sea ésta una situación imaginable como ficción, como problema de laboratorio, pensemos en la posibilidad que tendría el garajista o propietario de empresa de parking, si considerando formalizado un contrato de depósito sin más, retiene en prenda el vehículo hasta el pago com- 
pleto de la cantidad, siempre irrisoria en relación con el valor no sólo del vehículo, sino del perjuicio que puede causar dicha inmovilidad a su usuario, apoyándose en el tan claro precepto del artículo 1780 de nuestro Código Civil.

Por todo ello no se puede sino concluir diciendo que la regulación legal de la figura como tal resolvería situaciones y desequilibrios actualmente inevitables y es que, la Ley debe ir a la par con la realidad en constante evolución.

\section{NOTAS:} 489.

(1).- Nota en CASTAN: Derecho Civil Común y Foral. Tomo III. Madrid 1983, pág.

(2).- FUBINI: Contribución al estudio de los contratos complejos en Revista de Derecho Privado, 1931, págs. 1 y ss.

(3).- ROCA JUAN: El contrato de exposición, Murcia, Publicación del Seminario de Derecho Privado, 1984, pág. 28.

(4).- ENNECCERUS: Tratado, T. II, vol. $2^{o}$, pág. 7 de la $3^{a}$ edición española.

(5).- ROCA JUAN: Comentarios al Código Civil y Compilaciones forales dirigidas por Manuel Albaladejo. Tomo XII, vol. I, pág. 199, Madrid 1986.

(6).- En efecto los contratos de adhesión se caracterizan en palabras de Messino, por la imposición de determinadas claúsulas o del completo esquema del contrato por parte del contrayente económicamente más fuerte, en sentido ventajoso para él y en detrimento del otro contrayente, el cual siendo económicamente más débil, no tiene libertad de escoger, sino entre aceptar aquellas claúsulas o aquel esquema, o renunciar a la celebración del contrato $(*)$ (Nota 2 en la obra de Castán: Derecho Civil Español Común y Foral. Tomo III. Madrid 1983. Pág. 472). Sin embargo en el tipo de contratos que nos ocupa, ni las condiciones se plasman minuciosamente, y aun más, ni siquiera en el ticket, ni en cualquier otro documento se plasma la firma del propietario del vehículo en prueba de conformidad.

(7).- Cf. DIEZ PICAZO Y GULLON: Sistema de Derecho Civil. Tecnos Madrid 1983. Pág. 37-38.

(8).- Tendríamos por tanto que seguir un criterio similar al utilizado por la Ley General par la Defensa de los Consumidores y Usuarios 26/1984, de 19 de Julio que establece en su artículo décimo, punto segundo que "A los efectos de esta Ley, se entiende por claúsulas, condiciones o estipulaciones de caracter general, el conjunto de las redactadas previa y unilateralmente por una Empresa o grupo de Empresas para aplicarlas a todos los contratos que aquéllas o éste celebren, y cuya aplicación no puede evitar el consumidor o usuario, siempre que quiera obtener el bien o servicio de que se trate."; según la referida Ley dichas cláusulas, condiciones o estipulaciones deben cumplir la buena fe y justo equilibrio de las contraprestaciones, lo que entre otras cosas, excluye: Las limitaciones absolutas de responsabilidad frente al consumidor o usuario. (art. décimo, apartado primero, subapartado c-6o). Así según el articulado de esta ley, serían nulas las condiciones que limitasen dicha responsabilidad (apartado cuarto). 


\title{
PRECEDENTES HISTORICOS DEL CONCEPTO DE LEY ANTERIORES A LA CONSTITUCION DE 1812
}

\author{
JOSÉ F. CHOFRE SIRVENT
}

Profesor de Derecho Constitucional.

Tanto en España como en el resto de Europa occidental, y como consecuencia de la propagación de las nuevas ideas, se va a experimentar una transformación radical en la configuración del sistema jurídico que había estado vigente en el siglo XVIII (1). En este siglo se manifiesta la existencia de una crisis jurídica con la que el Estado tropieza en su fase de expansión. La tendencia del poder estatal a universalizar y uniformar la ley choca frontalmente con el principio de diversidad jurídica propia del Antiguo Régimen (2).

El nacimiento del sistema constitucional en España va a dar lugar al comienzo de un largo proceso que se prologará hasta 1837 y que producirá finalmente -no durante la vigencia de la Constitución de 1812- una ruptura total con respecto al Antiguo Régimen, a pesar del empeño mostrado por la mayoría de los diputados que participaron en la Comisión constitucional, de conjugar "tradición y modernismo". La pretensión manifestada de armonizar ambos términos, y no excluir la "tradición" (3), como hubiera sido propio de una situación estructuralmente divergente a la del antiguo Régimen, no ocultaba sino un deseo de invocar la tradición como fuente de legitimidad con el objetivo de realizar las reformas que la nueva situación constitucional demandaba (4).

La Constitución de 1812 supuso, pues, en nuestra Historia una "radical innovación" con respecto al pasado más inmediato. Las antiguas Cortes no mantienen ningún vínculo de conexión con las Cortes de Cádiz. Afirma Carlos de Cabo, que no existe continuidad entre las Asambleas feudales y el Parlamento moderno surgido de las revoluciones burguesas, como consecuencia de los diferentes supuestos básicos sobre los que se asientan unas y otro. Este autor fundamenta la ruptura en el distinto modo de producción al que responden, configurándose, en un caso, en base a supuestos típicamente feudales, como la organización estamental y el contrato feudal, mientras que el otro se basa en supuestos teóricos típicamente burgueses, como el concepto abstracto de la nación, de soberanía y de representación nacional (5). Aunque la hipótesis que maneja el profesor citado tiene un carácter general es aplicable al caso español pues aunque el modo de producción capitalista no estaba implantado definitivamente, por una coyuntura específica que tiene que ver con el dislocamiento histórico que produce la Guerra de la Independencia, la burgesía fue como en el supuesto más general contemplado- la protagonista en el constitucionalismo de Cádiz. 
Es la primera vez, por tanto, que se consolidan las Cortes como un órgano auténticamente parlamentario con plena capacidad para elaborar y aprobar diversos tipos de normas jurídicas.

En este contexto, el concepto de ley no va a resultar ajeno a los cambios tan significativos que se fueron operando en los albores del constitucionalismo (6). Para conocer en sus justos términos la configuración de la ley en la Constitución de 1812 es imprescindible señalar que, bajo las diferencias estructurales existentes entre los dos regímenes, subyacían ciertas semejanzas en la conformación de ambos sistemas normativos.

Sin desconocer en absoluto la distancia que separan a ambos sistemas normativos, existen ciertos rasgos que, surgidos en el Antiguo Régimen (7) permanecen en los inicios del constitucionalismo en España, aunque sujetos a ciertas correcciones derivadas de la nueva situación (8). En este mismo sentido se manifiesta Gallego Anabitarte cuando, invocando el Discurso Preliminar a la Constitución de 1812, afirma que existe "una concepción de ley y actos del Estado de carácter institucional que tenía tradición secular" (9). Por tanto, parece que puede afirmarse, que algunas de las características básicas de la ley ya se manifestaban en el Antiguo Régimen, aunque en el constitucionalismo fueran corregidas en alguna medida.

En todo caso, con el constitucionalismo se instaura un nuevo sistema de categorías normativas ("decretos de Cortes con carácter de ley", "decretos de competencia exclusiva de las Cortes", "decretos de Cortes a propuesta de S.M." "decretos de Cortes dando consentimiento a S.M." y las "órdenes de las Cortes", etc.) alejado del existente hasta ese momento (pragmáticas, cédulas, provisiones, etc.), aunque, sin embargo, los hábitos y ciertos rasgos fundamentales tradicionales han permanecido en el nuevo modelo de producción normativa, al menos, durante el primer tercio del siglo XIX, En consecuencia, la ruptura entre el sistema normativo del Antiguo Régimen y el instaurado con la Constitución de 1812 no es tan radical como aparentemente pudiera pensarse.

1) Rasgos del sistema normativo del Antiguo Régimen que han pasado a la Constitución del 1812.

En el Antiguo Régimen, las Cortes no eran verdaderamente Asambleas legislativas, ya que no podían hacer leyes; su labor se limitaba a pedir o proponer leyes, correspondiendo al Rey la facultad de dar o negar las mismas (10). Como ya afirmó en 1707 Felipe V, "uno de los principales atributos de la soberanía es la imposición y derogación de leyes" (11), y como la soberanía residía en el Rey, correspondería a éste el ejercicio de tan importantes funciones, marginado a las Cortes en el desempeño de las mismas. Cortes que, durante el siglo XVIII, se constituyeron en muy escasas ocasiones (cuatro bajo Felipe V, una con Carlos III y otra bajo carlos IV), y cuando se reunían no eran más que asambleas formales, carentes de todo poder legislativo, ya que este reside en el Rey quien lo ejerce, en la mayoría de los casos, a través del Consejo Real. Por el contrario, en el marco de Constitución de 1812 le corresponde a las "Cortes con el Rey" la postestad de hacer las leyes. El reconocimiento de estos caracteres globalmente tan divergentes no impide sin embargo 
observar como algunos rasgos del sistema normativo, pertenecientes al Antiguo Régimen, han pasado a la Constitución de 1812 y a la práctica legislativa de la época en la que estuvo en vigor ésta Constitución.

\section{A) La ley se "vehicula" por medio de otras categorías normativas.}

Así, en primer lugar, en los siglos XVI y XVII existen normas sustantivas, como las "células" y las "provisiones", entre otras, que se convirtieron en vehículos de publicación de la ley en el siglo XVIII. Si las "células" son las normas más abundantes del Antiguo Régimen, entre los siglos XVII y XVIII se aprecia un aumento de las "pragmáticas", que igualmente se constituyen en vehículo de publicación de la ley. Al final de la parte dispositiva de las "pragmáticas" se decía: "Todo lo cual quiero que se observe y guarde como ley y pragmática sanción hecha y promulgada en Cortes" (12). Esta claúsula contenida el final de la parte dispositiva de las pragmáticas planteaba un problema fundamental: y es el relativo a la novedad y al significado que ha de atribuirse a la ley, única ocasión en que se utiliza con carácter general en el Antiguo Régimen. Como se acaba de indicar, las categorías normativas del Antiguo Régimen fueron, entre otras, las "pragmáticas", "decretos", "cédulas", pero en ningún caso la ley podía considerarse como un tipo normativo concreto. Más bien la ley respondía a una práctica seguida en torno a la manera de estructurar de forma coherente una serie de disposiciones de épocas anteriores que se recogían expresamente en las Recopilaciones con su propia denominación. Ejemplos que vienen a corroborar lo que decimos los encontramos en la forma que el término "ley" aparece en la Nueva y en la Novísima Recopilación. En estos textos, las disposiciones normativas aparecen divididas en libros y en títulos y dentro de éstos en leyes (13). Por tanto, aunque en el Antiguo Régimen sea utilizada la expresión "ley" ésta no ha de interpretarse como una categoría normativa con sustantividad propia. La ley, en el Antiguo Régimen, no existía como tal. En las escasas ocasiones en que se utiliza este vocablo está vacío de contenido (14). Si en el Antiguo Régimen la ley se manifiesta a través de otras categorías normativas (piénsese en las "pragmáticas" cuando se dice en la parte dispositiva "que se observe y guarde como ley"), en el período en el que está vigente la Constitución de 1812 también podríamos afirmar que las leyes no existen como tales, sino que se vehiculan por medio de "decretos de Cortes". Por tanto, en el Antiguo Régimen y en los primeros años del régimen constitucional, la ley, "expresión de la voluntad de la nación", como categoría normativa básica de todo el constitucionalismo futuro, no revestirá su propio nombre, sino que estará a cubierto de otra categoría normativa: el "decreto de Cortes".

La inercia del Antiguo Régimen parece dejarse sentir, en alguna medida, en un sistema normativo tan lejano en sus fundamentos de aquél, como es el derivado de la Constitución de 1812. El cambio de un régimen a otro, en lo referente al sistema normativo, no se produjo de manera radical e instantánea, como si el pasado más inmediato dejarse repentinamente de existir, sino que la mutación se llevó a cabo a través de un proceso más o menos continuo en el tiempo. Lo que permite y explica que ciertos elementos del Antiguo Régimen, como algunos aspectos del sistema 
normativo, pugnen por continuar en el orden constitucional hasta que definitivamente desaparezcan (15).

B) Diversidad de categorías normativas y necesidad de acudir a los elementos que las integran para poder identificarlas.

Durante el Antiguo Régimen (siglo XVIII) existe una gran variedad de tipos de textos normativos como, "pragmáticas", "provisiones", "cédulas", "instrucciones", "circulares", "reglamentos", "decretos", "ordenes" y "autos acordados", como se acaba de decir. Pues bien, para poder ser identificados cada uno de ellos es preciso tener en cuenta los elementos que los componen, ya que éstos no siempre son los mismos, constituyéndose por ello en su carácter diferenciador (16).

Los elementos que caracterizan a cada tipo normativo varían de uno a otro, y son los siguientes: el protocolo (relación de títulos y Estados sobre los que el monarca ejerce su soberanía), la dirección (relación de los destinatarios de la norma a los que se encarga cumplan y hagan cumplir o dispuesto en la misma), la parte dispositiva (en ocasiones se integra de dos partes, el preámbulo y la resolución), la sanción (se refleja por la firma del Rey, y constituye un elemento esencial para diferenciar una categorías normativas de otras), el refrendo (igual que la sanción es otro de los requisitos que permiten diferenciar distintas normas entre sî) y, por último, se señalan dos elementos formales: el registro y la certificación, que tampoco concumen necesariamente en todas las categorías normativas (17). Así, según cuáles sean los elementos que coincidan en cada caso nos encontraremos ante una u otra categoría normativa. En este sentido se consideraba que la norma más completa y solemne desde el punto de vista formal era la "pragmática".

Pues bien, en la Constitución de 1812 también existen diversidad de tipos normativos emanados de las Cortes ("Decretos de Cortes con carácter de ley", "Decretos de competencia exclusiva de las Cortes", "Decretos a propuesta de S.M.", "Decretos de Cortes dando su consentimiento al Rey" y las "Ordenes de las Cortes"), que para poder determinarlos es necesario averiguar cuáles son los elementos que los integran, es decir, la fórmula de encabezamiento, la fórmula de cierre, indagar si existe una orden de promulgación, si son objeto de sanción por parte de S.M., etc. (En los apartados correspondientes tendemos ocasión de analizar profundamente toda ésta problemática relativa a la diversidad de categorías normativas originadas en el seno de las primeras Cortes constitucionales). Indagación necesaria, porque si nos confiamos en lo que simplemente se determine en el enunciado del decreto de que se trate sin duda incurriríamos en ciertos errores derivados de la inexactitud con que se emplean ciertos términos. Así, por ejemplo, existen "decretos de Cortes" en cuyo enunciado se dice que son sancionados por el Rey y, sin embargo, no se ha producido el cumplimiento de tal requisito. Por ello se precisa determinar los elementos que componen una concreta norma con el objeto de calificarla como corresponda.

Pero además de la importancia que tienen para identificar una determinada categoría el examinar los elementos que la componen, es preciso señalar la común característica entre el Antiguo Régimen y la Constitución de 1812 en lo relativo a la 
variedad de tipos normativos provinientes, bien del Consejo Real, bien de las Cortes, según se trate. Constituye una imagen distorsionada de la realidad considerar que las Cortes primeras del constitucionalismo producen únicamente leyes, como sería propio de un sistema jurídico inspirado en dichos principios innovadores. Pero la realidad demuestra que los mecanismos de producción normativa, tan arraigados en el Antiguo Régimen, parecen resistirse a su desaparición. Es verdad que ahora las Cortes intervienen en el pleno ejercicio del poder legislativo, pero, sin embargo, y como ya sucedía en el Antiguo Régimen con el Consejo Real, la pluralidad de disposiciones es nota común que vincula ambos sistemas normativos que tan dispares y distantes se encuentran desde el punto de vista estructural.

C) Categorías normativas que, además de contener textos normativos, en otras ocasiones puede abarcar otros actos.

También en el Antiguo Régimen es importante señalar que algunos tipos de texto normativo como la "cédula", el "decreto" o la "provisión" podían ser utilizados no sólo como tales normas, sino también para publicar otra clase de actuaciones del Estado, como, por ejemplo, nombramientos, donaciones, privilegios, órdenes de pago, etc. (18). Asimismo, durante la Constitución de 1812, los "decretos de Cortes", además de contener textos normativos, también se refieren a actos concretos, como concesiones de gracias, concesiones de carta de naturaleza, nombramientos, etc.

A modo de conclusión conviene señalar que, si bien puede parecer superficial detenerse en la comparación de algunos elementos de sistemas normativos tan radicalmente dispares, en realidad no es así, porque de esta manera pretendemos demostrar que el sistema jurídico inspirado en los principios ideológicos del Estado liberal no logró imponerse en toda su extensión y con carácter inmediato sobre una realidad profundamente arraigada en el Antiguo Régimen. La tensión aguda entre los intentos para instaurar el régimen constitucional y las réplicas por restaurar el Antiguo Régimen fue una constante durante la vigencia de la Constitución de 1812.

De tal manera, que las categorías normativas -que es el aspecto que directamente nos afecta, aunque estas afirmaciones pudieran extenderse a otros ámbitos- del Antiguo Régimen, si bien no pasaron al sistema constitucional, sí que lo hizo, por ejemplo, el mecanismo de utilizar una norma como "vehículo" de aprobación de otra. En todo caso, y es un hecho suficientemente conocido, que durante gran parte del siglo XIX permanecieron en vigor sectores jurídicos pertenecientes al Antiguo Régimen, como las Partidas o la Novísima Recopilación, con otros inspirados en la ideología liberal.

Así, pues, la transición del preconstitucionalismo al constitucionalismo no fue tan radical como formalmente pudiera parecer. La dispersión normativa, característica propia del Antiguo Régimen, aún continúa en el constitucionalismo. Los rasgos definidos nos conducen a una fase de transición entre un Estado estamental, que se encuentra agonizando, y un Estado constitucional que pugna fuertemente, y no con pocas dificultades, por consolidar su situación. En definitiva, pues, el Estado que emerge en los comienzos del siglo XIX pudiera definirse como de un "Estado jurí- 
dico-político de la transición" en correspondencia con la formación social española en transición al capitalismo.

Puestas ya de manifiesto algunas de las características semejantes entre los sistemas normativos del Antiguo Régimen y el establecido a raíz de la Constitución de 1812 sería conveniente detenerse, siquiera brevemente, en el examen del "Discurso Preliminar", porque, como indicaba Sánchez Agesta, este "es notoriamente superior a la Constitución en que se inspiró" (19). Difícilmente abarcaríamos, pues, el completo sentido del concepto de ley, si ignoramos las líneas fundamentales que iluminaron la gestación de la Constitución de 1812. Pero antes de abordar la configuración de la ley en el "Discurso Preliminar" es preciso referirse al primero de los Reglamentos habidos para el gobierno interior de las Cortes, de 24 de noviembre de 1810.

2) La configuración de la ley en el "Reglamento para el gobierno interior de las Cortes", 24 de Noviembre de 1810.

Es precisamente en este primer Reglamento de las Cortes (aprobado justo dos meses después de la declaración de la legítima constitución de las Cortes, en virtud del Decreto de 24 de Septiembre de 1810, y que no llegó a comunicarse oficialmente al Consejo de Regencia ni se incluyó en la Colección de Decretos de Cortes), en el que se desvelaron las primeras y rudimentarias manifestaciones de la peculiar concepción de ley que iba a estar vigente todo el siglo XIX y parte del XX en España. Todo ello en el entendimiento de que el concepto de ley "no nace" ni se configura repentina y deliberadamente en éste Reglamento, sino que "se va haciendo" a lo largo de nuestra tradición histórica secular, como tendremos ocasión de explicar más adelante.

Si fijamos el 24 de Septiembre de 1810 como el día en que se colocó "La piedra angular de la Constitución que dos años más tarde había de jurarse" (20) observaremos que es en el Decreto de Cortes de la citada fecha (en el que se declaró la legítima constitución de las mismas y de su soberanía), cuando por primera vez, en el constitucionalismo español, se señala con términos expresos la existencia de dos clases de normas que pueden elaborar y aprobar las Cortes: las "leyes" y los "decretos de Cortes". En los mismos orígenes del constitucionalismo se descarta, pues, la posibilidad de que las Cortes elaboren y aprueben exclusivamente leyes, como en principio le correspondería, permitiéndose así que la expresión de la voluntad de la Nación se concretase en éstas dos categorías normativas (aunque existen, a su vez, varias clases de "decretos de Cortes"). Así, en el precitado Decreto I, se dice: "El Consejo de Regencia, para usar de la habilitación declarada anteriormente, reconocerá la soberanía nacional de las Cortes, y jurará obediencia a las leyes y decretos de que de ellas emanaren;". El mismo sentido sigue el Decreto II, de 25 de Septiembre de 1810, que afirma en el encabezamiento del mismo, "que el ejecutivo debe publicar las leyes y decretos que emanen de las Cortes", y más adelante, incidiendo en las mismas ideas, se declara que "Las Cortes generales y extraordinarias ordenan que publicación de los decretos y leyes que de ellas emanaren se haga por el poder ejecutivo en la forma siguiente:". Y, por último, en el Decreto IV, de 27 de Septiembre de 1810 , relativo a la "declaración de las facultades y responsabilidades 
del poder ejecutivo, y del modo con que éste debe comunicarse con las Cortes, a consecuencia de las dudas que el Consejo de Regencia expuso a las mismas", manifestó éste que "no dudo un solo instante en prestar el juramento de obediencia a las leyes y decretos que emanaren de las Cortes".

De este modo, pues, lo que recoge con posterioridad el Reglamento de las Cortes no es sino el poso que ha ido dejando la historia al distinguir entre "hacer las leyes" y "otros actos" (21), revistiendo estos forma distinta. Porque, en efecto, uno de los temas importantes y vertebrales que quedan expuestos en el articulado del referido Reglamento es la constatación efectiva de que las Cortes, además de la función que propiamente le corresponde como es la de "hacer leyes", también le compete la de aprobar "decretos de Cortes" e, incluso, "órdenes" (distinción de enorme trascendencia, con importantes implicaciones políticas, como más adelante explicamos) (22), como se establece en el artículo 6, del Capítulo III, "De los Secretarios", que hace referencia a "las resoluciones y decretos de las Cortes".

Pero el núcleo central sobre el cual ha de girar nuestra investigación, que es definir el concepto de ley, encuentra una apoyatura fundamental en el artículo 1, del Capítulo VIII, "De los Decretos", del "Reglamento para el Gobierno interior de las Cortes", de 24 de Noviembre de 1810, que reza así: "Las resoluciones o acuerdos que las Cortes eleven a la clase de decretos o leyes, se remitirán al Consejo de Regencia para su publicación y ejecución", (23). En primer término observamos que, explícitamente, se distinguen los "decretos de Cortes" y la "ley". Por tanto, las Cortes están legitimadas para manifestarse por medio de ambas categorías normativas (hay que recordar, como ya se dijo, que también las Cortes pueden dictar "Ordenes"). La ley, como expresión genuina y propia de las Cortes, no lo puede todo y existe conciencia de su acotamiento del ámbito material normativo. Pero la pregunta que ahora se nos plantea no es otra que la de precisar en qué supuestos podrá utilizarse una u otra norma, teniendo presente que en este momento histórico no existe Constitución que pueda aclarar los términos de tan importante y decisiva cuestión.

El referido artículo atribuye a la decisión exclusiva de las Cortes si una determinada resolución ha de "elevarse a la clase de decretos o leyes". Ante el mutismo mostrado por este precepto en torno a los criterios a que ha de ajustarse la decisión que adopten las Cortes para calificar a una norma como "decreto" o "ley", se hace necesario indagar en otras partes del "Reglamento para el Gobierno Interior de las Cortes" si existen algunos datos que nos permitan fijar los parámetros en el marco de los cuales las Cortes resolverán.

$\mathrm{Y}$, ciertamente, los resultados que se obtienen no son lo suficientemente esclarecedores como sería deseable, aunque proporcionan algunos indicios que en los años sucesivos se verán confirmados con mayor precisión. Concretamente, en el Capítulo VI, "De las votaciones", del "Reglamento para el Gobierno Interior de las Cortes", se manifiestan, siquiera veladamente, algunos datos que nos señalan la dirección para distinguir entre "ley y "decreto de Cortes".

Así, después de destacarse la importancia del acto de la "votación" como instru- 
mento fundamental para explorar la voluntad general de que depende la sanción de las leyes (art, 1) (24), se dedica una especial atención a los diferentes modos de realizarse ésta. Sin duda, las distintas clases en que pueden realizarse las votaciones no revestirían mayor importancia en relación con el objeto de nuestra investigación, sino fuera porque es precisamente en la determinación de una u otra clase de votación donde se pose de manifiesto de modo embrionario si una concreta materia se instrumentará vía "decreto de Cortes" o "ley". De manera, que la adopción de una u otra forma de votación será "según la naturaleza de los asuntos" (art, 2, del "Capítulo VI", del "Reglamento para el Gobierno Interior de las Cortes"). Así, de los cuatros modos de votación reconocidos ("por aclamación", "por escrutinio", "por el acto de levantarse los que estén por la afirmativa" y " por la expresión individual del sí o el no") serán los dos últimos citados los que revelan cieto interés para el objetivo que se pretende.

La "votación por el acto de levantarse los que estén por la afirmativa" constituirá el modo de proceder normal "en asuntos triviales", aunque matiza el propio art. 11, del Capítulo VI, que también podrá usarse "en los (asuntos) de importancia, siempre que la opinión general se vea muy inclinada a uno de los extremos". Pero, sin duda, el modo de votación que más luz proporciona, dentro de los escasos datos exitentes, es el que tiene lugar "por la expresión individual del Sí o el No" (art. 13, del Capítulo VI). Por medio de este tipo se harán las votaciones de los asuntos que "se gradúen de importancia". Pero, la pregunta que inmediatamente se plantea es a quién corresponde decidir la importancia de un asunto determinado. Y el mismo art.13 señala que, "como estos casos no pueden expresarse en un reglamento, los acordarán las Cortes cuando ocurran". Podemos observar, pues, que la "naturaleza del asunto", la "importancia" mayor o menor de la materia objeto de regulación, es criterio clave para la distinción entre "decreto de Cortés" y "ley", aunque en verdad la claridad de la misma, si bien se apunta ahora, será una vez aprobada la Constitución y el primer Reglamento de las Cortes (en 1813, ajustado por consiguiente a la Constitución) cuando se manifiesten con diafanidad todos los contornos delimitadores de ambas categorías normativas. Reténgase ahora el dato de que el en período preconstitucional las Cortes no sólo elaboran y aprueban leyes, como sería lo propio del poder legislativo, sino que se reconoce, de un modo un tanto indefinido en sus contornos, la existencia de categorías normativas diferentes a la ley como son los "decretos de Cortes" y las "órdenes".

3) La configuración de la ley en el "Discurso preliminar a la Constitución de $1812 "$.

La determinación de las características fundamentales del concepto de ley que se contiene en el "Discurso Prelimininar", no puede ser ajena a las relaciones que mantengan los poderes legislativo y ejecutivo. Esta línea de análisis que vincula el concepto de la Ley y los poderes legislativo y ejecutivo parece que es la seguida por el "Discurso Preliminar".

Es un principio básico reconocido en el "Discurso Preliminar" y, posteriormente, en la Constitución de 1812, que la Nación es "soberana e independiente, bajo cuyo principio se reserva la autoridad legislativa" (25). El órgano que representa a 
la Nación es las Cortes, y, por tanto, es a éstas a quienes les corresponde la facultad de hacer las leyes, en cuya labor el Rey es "participante de la misma autoridad (legislativa)" (26), por medio de la sanción. Pero, además, corresponde a S.M. constituirse en "depositario de la potestad ejecutiva en toda su extensión" (27). Así, de ésta manera, se distingue, por un lado, la potestad legislativa, ya que "los hombres se han de dirigir por reglas fijas y sabidas de todos" (28), y, por otro lado, la potestad ejecutiva, a la que le corresponde el desarrollo de tales reglas conducentes al bien de la Nación. Y en términos expresos el "Discurso Preliminar" manifiesta la diferencia existente entre ambas potestades cuando afirma que la "formación (de las reglas fijas y sabidas) ha de ser un acto diferente de la ejecución de la que ellas disponen" (29).

Consciente, pues, la Comisión Constitucional de que el Rey puede alterar, siguiendo ejemplos pasados, la índole de la Monarquía, se "ha mirado como esencialísimo todo lo concerniente a las limitaciones de la autoridad del Rey" (30). Y así, "se han señalado con escrupulosidad reglas fijas, claras y sencillas que determinan con toda exactitud y precisión la autoridad que tienen las Cortes de hacer las leyes de acuerdo con el Rey; (y) la que ejerce el Rey para ejecutarlas y hacerlas respetar" (31). Como bien puede observarse hasta ahora, resalta el especial interés de la Comisión para evitar que puedan llegar a confundirse el ejercicio de las dos potestades. Para garantizar la consecución de tal objetivo "Las facultades de las Cortes se han expresado con individualidad, para que en ningún caso pueda haber ocasión de disputa o competencia entre la autoridad de las Cortes y la del Rey" (32), excluyéndose de este modo, incluso, la sanción de S.M., porque si ésta es negada por el Rey puede provocar un conflicto entre el Jefe del Estado y las Cortes, que es, precisamente, lo que se quiere evitar, atribuyéndose con tal fin a las Cortes unas facultades expresadas con "individualidad". Para subrayar con gruesos trazos que las facultades de las Cortes pertenecen "exclusivamente" a ellas mismas, señala más adelante la propia Comisión que "Cadad una de ellas (de las facultades) pertenece por su naturaleza de tal modo a la potestad legislativa, que las Cortes no podrían desprenderse de ellas sin comprometer muy pronto la libertad de la nación" (33).

Llegados a este punto de la exposición observamos que en el texto del "Discurso Preliminar" hay algunos conceptos que no están definidos con la nitidez que sería deseable. Por una parte, se hace referencia a que corresponde a las Cortes, con la participacón del Rey, "hacer las leyes", y, por otra, se excluye al Rey de cualquier mínima intervención cuando trate de regular aquéllas facultades expresadas con "individualidad" y que pertenecen en "exclusiva" a las Cortes. De ésta distinción se colige, que los productos normativos emanados de las Cortes -bien en exclusiva, o bien con participación del Rey- son de dos clases: las leyes, en las que se exige la intervención del Rey, y los "decretos de Cortes" (sin sanción), que son productos de la exclusiva voluntad de las Cortes. La existencia de ambas categorías normativas encontraría justificación en razones políticas, por cuanto al atribuir ciertas materias a la competencia exclusiva de las Cortes se evitaría que el Rey pudiese intervenir por medio de la sanción. Pero no es sólo este argumento político el único 
que puede invocarse, sino también otro de naturaleza técnica que, a su vez, está fundamentado en la tradición histórica española.

Concretamente se estima que "hacer una ley" constituye un acto muy diferente (34) al de adoptar decisiones concretas, fijar resoluciones, dar consentimiento, etc. Agustín de Argüelles, al hilo de la discusión en el seno de las Cortes acerca del art. 27 del Proyecto de Constitución afirmaba en 1811: "Las Cortes sucesivas no serán más que un Congreso legislativo, en el cual solo se ventilarán proyectos o materias de ley, y los asuntos cuya naturaleza les corresponde por la Constitución" (35). Pues bien, en éstos asuntos atribuídos por la Constitución al "Congreso legislativo", y que son de naturaleza distinta a la ley, nos encontramos ante un "Decreto de Cortes" (sin sanción), y no ante una ley, aunque uno y otra tengan su origen en el mismo poder legislativo. Así, por ejemplo, "el establecimiento de impuestos y contribuciones" es un "derecho inseparable de la facultad de hacer las leyes" (36), no pudiéndose llegar a confundir ambas competencias -hacer las leyes y establecer los impuestos-, lo cual supone, en definitiva, que la materia impositiva ha de instrumentarse por vía diferente a la de la ley, esto es, por "decreto de las Cortes", siendo en último término el Poder legislativo, con carácter exclusivo, y como único órgano que representa a la soberanía nacional, el que expresa su voluntad (37). Y, además, en plena coherencia con lo anterior, se consideraba a ésta facultad de las Cortes (establecer impuestos) como comprendida dentro de aquéllas que se han expresado con "individualidad", es decir, aquéllas en que el Rey no puede intervenir en ningún caso en evitación de eventuales conflictos entre las Cortes y el Rey, y que el poder legislativo no podrá desprenderse de ella sin poner en peligro la libertad de la nación (38).

En el apartado del Discurso Preliminar relativo al "otorgamiento de los impuestos" (39) es constante la repetición de expresiones del siguiente tenor: "las Cortes establecerán o confirmarán anualmente todo género de impuestos y contribuciones"; "decretadas por las Cortes las contribuciones"; el Rey podrá aplicar al mejor servicio de la nación los fondos públicos "puestos a su disposición por las Cortes"; "aprobada por las Cortes la cuenta general de tesorería mayor" (40).

En torno a ésta misma polémica, durante la vigencia del Estatuto Real, de 1834, se suscitó una histórica disputa acerca de si el presupuesto del Estado debía revestir forma de ley o de "decreto de Cortes". Después de un muy interesante debate, en la que se dejaba entrever resgos de lo que años después se convertiría en clásica dicotomía entre ley formal-ley material, el asunto quedó zanjado a favor de calificarlo como "ley". La decisión finalmente adoptada permitía al Rey controlar los presupuestos por medio de la sanción cosa que no hubiera ocurrido si la calificación hubiera sido "decreto de Cortes sin carácter de ley", como sucedió en el marco de la Constitución de 1812 (41).

Iguales consideraciones cabrían invocar -en el Documento que ahora se analizarespecto al apartado referido a "los ejércitos y la milicia". Y así se dice en el propio texto del Discurso Preliminar que, una vez explicados los fundamentos sobre los que reposa el derecho de las Cortes de otorgar anualmente las contribuciones e impuestos, "conviene hablar de otra facultad que tampoco una nación libre pue- 
de delegar sino al cuerpo de representantes. Tal es el levantamiento de tropas de mar y tierra para la defensa interior y exterio del Estado" (42). De nuevo nos encontramos con otra de las facultades que se englobaría dentro de aquéllas que corresponden en "exclusiva" a las Cortes, hurtando al Rey la posibilidad de intervenir. Y así se dice en diversos pasajes del apartado citado expresiones como las que siguen: se exige que "las Cortes fijen todos los años el número de tropas de mar y tierra que hayan de estar en ejercicio"; "es propio de las Cortes la formación y aprobación de ordenanzas, establecimientos y arreglos de escuelas militares, y todo lo que corresponda a la mejor organización, consevación y progresos de los ejércitos y armadas que mantengan en pie para la defensa del Estado"; "no debe estar autorizado (el Rey) para reunir cuerpos de milicia nacional sin otorgamiento expreso de las Cortes" (43).

También en ésta misma línea argumental se encuentran las materias relacionadas con "la educación pública" que, en consideración al sublime objeto que la misma supone, y la influencia que ha de tener para la "felicidad futura de la nación", exige que "las Cortes aprueben y vigilen los planes y estatutos de enseñanza en general, y todo lo que pertenezca a la erección y mejora de establecimientos científicos y artísticos" (44).

$Y$, por último, en el apartado final del Discurso Preliminar, relativo a la "reforma y defensa de la Constitución", se tribuye a las Cortes competencia "exclusiva" para aprobar la reforma propuesta de la Consititución (45). Sin duda, la atribución de tan importante facultad a las Cortes no hace sino subrayar elocuentemente lo que venimos afirmando, y es que en el "Discurso Preliminar", fundado en "las raíces tradicionales" españolas, se distinguían dos categorías normativas que tienen su origen, bien en las "Cortes con el Rey", y que daría lugar a las leyes; o bien en las Cortes "exclusivamente", y que produciría los "decretos de Cortes".

$Y$, asimismo, en el "Discurso Preliminar" se utilizan, creemos que por única vez a lo largo del texto, las expresiones "ley y decreto de Cortes" conjuntamente (46), lo que viene a subrayar una vez más cuál es el espíritu que se esconde tras las palabras del "Discurso Preliminar", aun siendo éstas tan importantes y diáfanas como hemos señalado anteriomente.

En conclusión, pues, los "decretos de Cortes con carácter de ley" tienen limitado su campo de actuación normativa. No pueden abordar la regulación de cualquier materia. Su limitación viene determinada por aquellas materias que están reservadas a la competencia exclusiva de las Cortes, y cuyo instrumento normativo es el "decreto de competencia propia de las Cortes".

\section{NOTAS}

(1) Vid. en este sentido Pérez-Prendes, José Manuel, Curso de Historia del Derecho español, Madrid, 1986, pág. 905. 
(2) Vid. Artola, Miguel, Los orígenes de la España contemporánea, Tomo I, Madrid, 1975, págs, 102 y 103.

(3) El primero de los problemas que afronta el Discurso Preliminar a la Constitución de 1812 es, precisamente, poner de manifiesto cuáles son las raíces tradicionales que fundamentan ésta Constitución. Y así, se señala: "Nada ofrece la Comisión en su proyecto que no se halle consignado del modo más auténtico y solemne en los difrentes cuerpos de la legislación española", vid. Argüelles, Agustín de, en Discurso Preliminar a la Constitución de 1812, Madrid, 1981, pág, 67.

(4) Como en tantas otras ocasiones, la Historia es utilizada por las diferentes posturas políticas en defensa de sus propios intereses. Así ocurrió en España en los primeros años del constitucionalismo. Simplificando, podemos señalar que existían dos interpretaciones diametralmente opuestas. Por una parte, se encontraban aquellos que pretendían organizarse según el modelo jurídico derivado de la Revolución francesa, y para justificar su opinión acudían a las Actas de las antiguas Cortes. Y, por otra parte, se situaban aquellos cuyo objetivo era propugnar la vuelta al antiguo Régimen, acudiendo, igualmente que los defensores de la anterior postura a las mismas fuentes. Vid. sobre esta polémica que tanta división trajo consigo, Pérez-Prendea, José Manuel, "Cortes de Castilla y Cortes de Cádiz", en Revista de Estudios Políticos, núm. 126, NoviembreDiciembre, 1962, págs, 321-431.

(5) Vid. De Cabo, Carlos, "Algunos aspectos de la problemática 'representación-partidos políticos'", en Teoría y práctica de los partidos políticos, Ed, de Pedro de Vega, Madrid, 1977, págs. 43-44.

(6) Si bien sobre otros muchos aspectos destacaban los posiciones enfrentadas entre diversos sectores sociales, en cambio, al tratar de las características de la ley se manifestaba "una impresionante comunidad de opiniones (que) se inclina en favor de reformas radicales, como la nacionalidad y universalidad de la ley y la formación de un código orgánico". Las pretensiones de configurar una ley de éstas características suponía que los españoles aspiraban ya a una patria española. Vid. Artola, Miguel, Los orígenes de la España contemporánea, Tomo I, Madrid, 1975, págs. 365-366.

(7) En relación con la Justicia, muchos de sus elementos del Antiguo Régimen provienen de la Edad Media y seguirán susbsistiendo durante mucho tiempo tras el rèstablecimiento del Estado liberal. Vid. Aparicio Pérez, Miguel Angel, El 'status' de la Administración de Justicia en el constitucionalismo (1812-1936), trabajo de investigación inédito, págs. 9-10.

(8) Conviene tener presente la importancia que para el progreso del constitucionalismo durante el siglo XIX tiene la labor desarrollada por la Ilustración, el racionalismo, el iusnaturalismo y los procesos evolutivos que acontecen en el siglo XVIII con la dinastía borbónica. En definitiva, en este siglo se establecen las bases, se preparan los caminos que desembocarán en el siglo XIX. Vid. Thieme, H.: La continuité et la discontinuité dans l'Historie du Droit. Conferencia pronunciada en la Universidad de La Laguna en 15 de Octubre de 1971, texto alemán en Kontinnizät... (Ed. por Trümpy), Darmstadt, 1973, págs. 150-166, cit. por Pérez-Prendes, José Manuel, Curso de Historia del Derecho español, Madrid, 1986, pág. 202.

(9) Vid. Gallego Anabitarte, Alfredo, Ley y Reglamento en el Derecho Público Occidental, Madrid, 1971, pág. 183.

(10) Vid. Salas, Ramón, en Lecciones de Derecho Público Constitucional, Madrid, 1982, pág. 165; en el mismo sentido se pronuncia Fernández Almagro, Melchor, en Orígenes del Régimen Constitucional en España. Barcelona, 1976, págs. 116-117, cuando afirma que la ley en el Antiguo Régimen, se daba por la Corona a ruego y como merced. Para Martínez Marina, citado por el propio Fernández Almagro, "las antiguas Cortes no gozaron de autoridad legislativa, sino del derecho de representar y suplicar". Pérez-Prendes, José Manuel, señala que "la facultad legislativa sólo radica en el rey y no en él y las Cortes conjuntamente", vid. Cortes de Castilla, Barcelona, 1974, pág. 151.

(11) Vid. Tomás y Valiente, Francisco, Manual de Historia del Derecho español, Madrid, 1979, pág. 377.

(12) Si las Cortes no se configuran como órgano legislativo qué significado cabría atribuir a la claúsula "como ley hecha y promulgada en Cortes". Según manifiesta Pérez-Prendes, el hacer una 
ley en las Cortes sólo quiere decir que se pública en ellas, "como medio de darles mayor solemnidad y difusión". Es decir, la publicidad es un requisito esencial para que la norma en cuestión alcance rango de ley. La misión de las Cortes será, pues, la de prestar difusión y conocimiemto por parte delos súbditos a las leyes promulgadas por el Rey "en" ellas, no "con" ellas. Lo que viene a significar que el monarca no comparte con las Cortes la postestad legislativa. Las Cortes se limitan a "aconsejar" al Rey, aunque sin vinculación jurídica. Vid de éste autor Cortes de Castilla, Barcelona, 1974, págs. 145-147.

(13) Como simples botones de muestra baste citar, por ejemplo, "Modo de recibir (los abades) los bienes de sus Monasterios, y prohibición de disponer de lo adquirido intuitu ecclesiae'" (ley 2. tít.5. lib. I.); "todas las (abadías) consistoriales son de patronato y presentación real (ley. 4. tit. 17. lib. I.); etc. Vid. Novísima Recopilación de las Leyes de España. Mandada formar por el Señor Don Carlos IV. Tomo VI, Madrid, 1807, pág. 1.

(14) Vid. Sobre las normas emanadas en el antiguo Régimen, Cabrera Bosch, María Isabel, "El Poder legislativo en la España del siglo XVIII", en La economía española al final del Antiguo Régimen. IV Instituciones. Edición de Miguel Artola, Madrid, 1982, págs. 238-242.

(15) Señala Pérez-Prendes, que la mera pervivencia de instituciones anteriores al origen del constitucionalismo no puede conducirnos a afirmar que aún perviva el Antiguo Régimen, Vid. Curso de Historia del Derecho Español, Madrid, 1986, pág. 906.

(16) Vid. op. cit. pág. 190.

(17) Vid. sobre el análisis de la norma en el Antiguo Régimen, Cabrera Bosch, María Isabel, op, cit. págs. 238-244.

(18) Vid. ídem.

(19) Vid. Argüelles, Agustín de, Discurso Preliminar a la Constitución de 1812, Introducción de Luís Sánchez Agesta, Madrid, 1981, pág. 63.

(20) Vid. Fernández almagro, Melchor, Orígenes del Régimen Constitucional en España, Barcelona, 1976, pág. 81.

(21) Ya en Aragón y en Castilla se tuvo un notable cuidado y vigilancia en guardar "los fueros y leyes que protegían las libertades de la nación en el esencialísimo punto de hacer las leyes". En época tan remota ya se distinguía entre "hacer las leyes" y "otras facultades de las Cortes". Así se afirma que: "Los congresos nacionales de los godos renacieron en las Cortes generales de Aragón, de Navarra y de Castilla, en que el rey, los prelados, magnates y el pueblo hacían las leyes, otorgaban pedidos y contribuciones y trataban de todos los asuntos graves que ocurrían" (Vid. Argüelles, Agustín de, Discurso Preliminar a la Constitución de 1812, Madrid, 1981, pág. 71). De tal manera, que tanto en Navarra, Aragón y Castilla las contribuciones son otorgadas libremente por la nación reunidas en Cortes sin intervención del Rey, distinguiéndose, pues, de la facultad de "hacer las leyes" (Vid. op. cit., págs. 72-73-74).

Recogiendo las raíces tradicionales en torno a ésta importante cuestión, el diputado Sr. Argüelles o quien hubiera sido el autor o autores del Discurso Preliminar (no está dilucidado quién fue el verdadero autor del Discurso Preliminar, pero sea Argüelles en solitario, o Argüelles con Espinosa, o toda la Comisión, la importancia histórica del mismo es incuestionable) trasladaron las mismas a la realidad de lo que se convertiría en la Constitución de $1812, \mathrm{y}$, además y es lo más importante, se proyectaría en las Constituciones futuras (la potestad de "hacer las leyes" correspondería a "las Cortes con el Rey", y, además, es de competencia exclusiva de las Cortes una determinada relación de materias. Así, en este sentido, el art. 40 de la Constitución de 1837; art. 39 de la Constitución de 1845; art. 41 de la Constitución "non nata" de 1856; art. 58 de la Constitución de 1869; y art. 45 de la Constitución de 1876).

(22) En estos términos expresos se manifiesta el "Decreto de Cortes, de 27 de Mayo de 1811", cuando declara "que los decretos y órdenes que emanan de las Cortes vayan, como hasta aquí, autorizados y firmados por dos indistintamente de los cuatro Secretarios. Lo tendrá entendido el Consejo de Regencia, y para que llegue a noticia de todos lo hará imprimir, publicar y circular. Dado en Cádiz a 27 de Mayo de 1811. -José Pablo Valiente, Presidente.- Pedro Aparici y Ortiz, Diputado Secretario.- Ramón Felíu, Diputado Secretario, -Al Consejo de Regencia-".

(23) El artículo 2, del Capítulo VIII, "De los Decretos", siguiendo en la misma línea marcada 
por el artículo 1, se expresa en los siguientes términos: "Los decretos y leyes que emanen de las Cortes se extenderán de la forma siguiente: "Don Fernando VII, por la Gracia de Dios, Rey de España y de las Indias, y en su ausencia y cautividad el Consejo Regencia, autorizado interinamente, a todos los que la presente vieren y entendieren, sabed que en las Cortes Generales y Extraordinarias congregadas en la Real Isla de León, se resolvió y decretó lo siguiente:".

(24) En estos años en los que el Rey está cautivo es las Cortes las que sancionan las leyes.

(25) Vid. Argüelles, Agustín de, Discurso Preliminar a la Constitución de 1812, Madrid, 1981, pág. 77.

(26) Vid. idem.

(27) Vid. idem.

(28) Vid. idem.

(29) Vid. idem.

(30) Vid. idem, pág. 80.

(31) Vid. idem.

(32) Vid. idem, pág. 88. La relación de facultades de las Cortes a que se hace referencia es la contenida posteriomente en el artículo 131 de Constitución de 1812.

(33) Vid. idem, pág. 88.

(34) En palabras de Gallego Anabitarte, "ley es una norma o regla jurídica 'principal', importante", en op, cit., pág. 186. Sin duda, la determinación de qué sea norma principal no es tarea que resulte fácil dilucidar. Parece que el criterio de la "impotancia", como elemento que contribuye para definir la ley, no es plenamente acertado porque, en este caso, materias tan relevantes como pueden ser los impuestos no son "importantes" al no revestir forma de ley.

(35) Vid. Diario de Sesiones de las Cortes Generales y Extraordinarias, 1810-1813, Tomo III, 12 de Septiembre de 1811, núm. 345, pág. 1831.

(36) Vid. Argüelles, Agustín de, Discurso Preliminar a la Constitución de 1812, Madrid, 1981, pág. 120. También se manifiesta en este sentido el Conde de Montlosier cuando afrima que: "Hacer las leyes y votar los impuestos,...", en Ensayo sobre el arte de constituir los pueblos, cit, por Martínez se la Rosa, en Espíritu del Siglo, Tomo I, Madrid, 1835, pág. 29.

(37) Vid. en igual sentido Gallego Anabiarte, op. cit., pág. 183-184.

(38) Vid. Argüelles, Agustín de, en op. cit., pág. 88-120.

(39) Los apartados en que se divide el Discurso Preliminar corresponden a la edición del Centro de Estudios Constitucionales, que es la venimos citando.

(40) Vid. Argüelles, Agustín de, en op. cit., págs. 120-122.

(41) Vid. Diario de Sesiones del Estamento de Procuradores, Legislatura 1834-35, Tomo II, 12 de Diciembre de 1834, págs. 874-876. El 12 de Diciembre de 1834 tiene lugar la histórica discusión acerca de si los Presupuestos del Estado debían revestir forma de "ley" ("decretos de Cortes con carácter de ley", en la terminología utilizada durante la vigencia de la Constitución de 1812) o de "decreto de Cortes" ("decreto de competencia exclusiva de las Cortes", según también los conceptos normativos utilizados durante la vigencia de la Constitución gaditana). En este debate intervienen tres relevantes personalidades políticas como son el Marqués de Montevirgen, Martínez de la Rosa, que ocupaba el cargo de Secretario del Despacho de Estado, y el Conde de Toreno, como Secretario del Despacho de Hacienda. Finalmente se decidió por considerar al Presupuesto como ley, quebrándode la tradición iniciada en Cádiz, que calificaba a los Presupuestos como "decretos de competencia exclusiva de las Cortes" (Vid. el art. 131, apdos. 1213 de la Constitución de 1812 en relación con el art. 110 del "Reglamento del Gobierno interior de Cortes y su edificio", de 29 de Junio de 1821) con la importante diferencia de que en el primer caso (Presupuestos como ley) se exige la intervención del Rey mediante la sanción, mientras que en el segundo caso (Presupuestos como "decreto de competencia exclusiva de las Cortes") la única voluntad que decide sobre los mismos es las Cortes. La trascendencia de esta discusión obliga a que transcribamos los pasajes más relevantes de la misma.

«El Sr. Marqués de MONTEVIRGEN: Para entrar en la discusión se duda si se podrá alterar o 
no alterar el art. 92 del Reglamento. La cuestión sobre presupuestos se presenta bajo la forma de ley, y los artículos 91, 92 y 93 del Reglamento determinan positivamente la marcha que debe seguir la discusión de todo proyecto de ley. La duda nace de la singularidad de la ley de presupuestos; singularidad que no se tuvo presente a la formación del Reglamento. El Estatuto Real marca positivamente la diferencia que hay de esta ley de presupuestos a las demás leyes comunes; por consiguiente no está sujeta a las fórmulas de ellas por ser de diferente naturaleza; y en el caso de ser considerada como ley, está prevenido lo conveniente en los artículos 32 y 34 del Estatuto Real, que dicen así: (Los leyó). No siendo la ley de presupuestos como las demás, debía haberse hecho un artículo particular que tratase de ella y quedaría comprendida en este artículo 33; más no se hizo así, y se formó el artículo 34 que dice: (Lo leyó). La diferencia que hacen estos dos artículos entre las leyes y votación de presupuestos, manifiesta que no están comprendidos estos en las leyes comunes; $y$ así no ha debido el Estamento arreglarse en su discusión a las disposiciones referentes a ellas. Además, en la exposición que antecede al Estatuto Real se manifiesta cual es su doctrina respecto de esto. (Lo leyó). De lo cual resulta que los presupuestos no son una ley sino un decreto, por más que se quiera decir que las disposiciones relativas a tributos y las cargas públicas son en realidad una ley, y una ley de importancia; pues a pesar de todo, les falta, entre otras cosas, para serlo la perpetuidad y la sanción Real.

Por otra parte, esta cuestión se presenta siempre de un modo diverso que las leyes comunes. El Estamento puede hacer una petición a S.M., a fin de que proponga una ley: la autoridad Real la presenta a las Cortes, éstas la discuten, y S.M. la aprueba y la sanciona. En este caso es al contrario: el derecho de petición lo ejerce la Corona; nos presenta los presupuestos y pide las contribuciones, y las Cortes, después de examinadas las aprueban.

Si se quiere por un momento que los presupuestos sean una ley, que en mi concepto no lo son porque no siguen todos los támites que se establecen para la formación de las leyes, son una ley de tan especial naturaleza, que no se puede someter a las forma de las leyes comunes, y por lo tanto no estamos en el caso de los artículos 91,92 y 93 del Reglamento. No estando pues en tal caso, no hay dificultad alguna en que acordemos el modo más expedito de deliberar sobre esta cuestión.

El artículo $1^{\circ}$ del proyecto de ley es otro de los embarazos que se presentan porque hay que aprobarlo o desaprobarlo para pasar a los demás: no estando este punto sujeto al artículo 92 del Reglamento, no tenemos necesidad de aguardar a aprobar el artículo $1^{\circ}$, y podemos entrar directamente a examinar el presupuesto de la casa Real. No incurriremos en otro de los inconvenientes que han manifestado algunos señores, a saber: que sería necesario votar un presupuesto supletorio para que las contribuciones no empezaran a exigirse sin permiso de las Cortes desde $1^{\circ}$ de Enero de 1835 .

Las propuestas por el Gobierno son de tal naturaleza que no pueden principar a cobrarse desde $1^{9}$ de Enero. En las de aduanas, que son las que se cobran diariamente, el Ministerio no ha hecho ninguna alteración, ni la comisión tampoco: de consiguiente me parece que no hay ningún inconveniente en que sigan según se hallan. El derecho de puertas, que también se cobra diariamente, no principiará a regir hasta $1^{\circ}$ de Marzo, por lo cual hay tiempo suficiente para plantearlo.

Los impuestos de frutos civiles, paja y utensilios son contribuciones que no se pagan al momento, sino por semestre vencidos anteriormente: por tanto, hay tiempo sobrado para hacer el repartimiento. Acordado por el Estamento que los presupuestos sean una ley, en mi concepto esta ley es de una naturaleza tan especial, que no puede estar sometida a las disposiciones generales de las demás leyes. Podremos pues desechar al artículo $1^{\circ}$, y entrar en la discusión del presupuesto de la casa Real, porque ni recauda ni distribuye. Recibe sí, pero percibe a cuenta: no hay, pues, ningún inconveniente en que reciba cualquiera cantidad a cuenta de lo que se acordase después; y mientras tanto se pueden discutir los otros presupuestos. En este concepto voy a hacer una proposición, pidiendo que no se comprendan los presupuestos bajo la forma general de las leyes; y me alegraría que el Estamento la aprobase, pues esto nos sacaría del grande embarazo en que nos hallamos.

El Sr. Secretario del Despacho de ESTADO: No voy a entrar en la discusión que desgraciadamente se suscitó ayer, y continúa hoy. He dicho desgraciadamente, porque todo la que sea retardar el entrar el Estamento en el ejercicio de la más importante de sus atribuciones, cual es la de exami- 
nar las cargas que han de imponerse a los pueblos para cubrir los gastos del Estado, lo miro como un mal muy grave. Sin embargo, por motivos de delicadeza que habrá comprendido la penetración del Estamento, los Secretarios del Despacho se han abstenido a entrar en la cuestión, excepto cuando algún Sr. Procurador, saliéndose de ella, ha hecho inculpaciones al Gobierno; pues en este caso han tenido que contestar a ellas, impulsados de su deber.

Así pues, si hago ahora uso del derecho que, como Procurador a Cortes y como Secretario del Despacho, me compete para tomar la palabra, es sólo porque habiéndose rozado la cuestión con un principio fundamental, importa mucho fijar las ideas con toda exactitud, sobre todo cuando principiamos a entrar en un régimen, que si bien no es nuevo, sino muy antiguo, puesto que trae su origen de las leyes fundamentales de la monarquía, con todo, el largo desuso en que por muchos siglos ha estado, le da cierto aspecto de novedad. En este supueto, y como la doctrina que acaba de expresar el Sr. Marqués de Montevirgen podría ser peligrosa, creo necesario rebatirla, aunque conozco que la intención de S.S. ha sido quitar embarazos al Gobierno, y acelerar el examen de los presupuestos, cuya dilación puede originar inconvenientes de trascendencia, S.S. ha anunciado y sostenido su opinión de que esta materia de presupuestos no es una verdadera ley; y de una manera muy ingeniosa se ha apoyado en que supuesto que en el Estatuto Real hay un artículo expreso sobre materia de contribuciones, es claro que no se comprende en la regla general de las demás leyes. Este es el principal argumento de S.S.; y por lo tanto tengo que hacer ver que es muy especioso, pero que no descansa en fundamentos bastantes sólidos. La imposición de las contribuciones es una verdadera ley, y como tal se reputa en todas las naciones que se gobiernan por un régimen representativo. Lleva y debe llevar el carácter de la ley, puesto que es un mandato obligatorio, general, que impone una carga a todos los individuos de una nación; y no se puede imponer carga alguna a una nación sin el concurso de los dos brazos principales del Estado, el poder legislativo y el poder Real. S.S. ha querido suponer que en materia de contribuciones se variaba el carácter de ley, puesto que en ella se invertía el orden que se observa en las demás, y en cierto modo la Corona ejercía una especie de derecho de petición; pero en esto se ha equivocado S.S. La Corona, así en esta como en las demás leyes usa del mismo derecho, propio suyo, la iniciativa; los Estamentos aprueban, modifican, reprueban y este es su derecho; y después falta siempre el sello de la sanción Real, que da la Corona; iy por qué? Porque la Corona es una especie de representante nato, hereditario, perpétuo de la nación; tal es el carácter sublime que da a la potestad Real el régimen representativo. El Monarca, es un representante de la nación permanente; a diferencia de los Procuradores a Cortes, que lo son transitorios y variables, y de los Próceres, cuando sólo son vitalicios. La Corona propone: los Procuradores y Próceres examinan, modifican, aprueban o reprueban, porque tal es su facultad; pero para la ejecución de lo propuesto y aprobado se necesita el sello de la sanción Real, sin el cual no tendrían derecho las autoridades para obligar a los pueblos a ejecutar lo dispuesto, ni obligación estos de obedecerlos; y en este caso, sin tal sanción, no se podría obligar a los pueblos al pago de las contribuciones. No hay pues diferencia entre la ley de presupuestos y las demás, ni en sus primeros trámites, ni en su examen, ni en su conclusión: iniciativa, aprobación y sanción; estos son los trámites que como todas tiene que sufrir. Si en el Estatuto Real se ha establecido un artículo expreso sobre ella, es porque S.M. en su alta sabiduría conoció que era preciso hacer una específica mención de ella; porque es la garantía más esencial, el más fundamental de los derechos de la nación, el que sirve para la conservación de todos. Acaso el ejercicio de votar los subsidios por las Cortes antiguas fue el que dio vida a la libertad castellana; y tal vez este mismo derecho, ejercido por la Cámara de los Comunes en Inglaterra, es el que ha mantenido en pie durante siglos las libertades de aquel país.

Solo el tener que presentarse el poder Real ante las Cortes para que otorgasen las contribuciones, mantuvo vivo el espíritu de libertad en Castilla; hasta que privándose a esas mismas Cortes del ejercicio de aquel derecho, desde que se excluyeron de ellas a dos brazos importantes del Estado, en las célebres Cortes de Toledo del año de 1538, quedó el brazo popular solo y débil, y se vió al fin privada la nación del ejercicio de sus derechos, y especialmente del de otorgar sus contribuciones; si bien quedó una especie de sombra que lo ejerciese, y ha durado hasta nuestros días en la Diputación de los reinos, que renovaba con la Corona las escrituras de millones. No se tenga por exageración; pero estoy firmemente persuadido de que este derecho importantísimo es la salvaguardia de todos los demás, y que donde quiera que exista es imposible que deje de haber libertad; porque es imposible que al ejercerla la nación, dejen de verse y corregirse los abusos que se introduzcan en los diversos ramos de la administración, y de ponerse coto a las demasías del poder. Por 
esta razón pues ha sancionado tan expresamente este derecho el Estatuto Real. Por esta misma razón el Ministerio, absteniéndose de entrar en la cuestión pendiente, ha dejado en entera libertad al Estamento para que decida el incidente suscitado.

Respecto a la discusión actual, solo diré que el Gobierno presentó todos los presupuestos unidos bajo el carácter solemne de una ley. Si los hubiera presentado aislados, acaso se hubiera hecho sospechoso de que no quería presentar el cuadro total de recursos y cargas de la nación. Los presentó formando un cuerpo; y hubiera sido fácil que se examinasen así por una comisión de ingresos y otra de gastos; pero el Estamento lo dispuso de otra manera, subdividiéndolos en varias comisiones particulares: el Ministerio no se opuso, porque creyó ver en esta subdivisión el deseo de profundizar más y más hasta el último detalle de los presupuestos. Convino es esto; ¿y por qué? Porque creyó que el objeto no era retardar ni embarazar el examen de los presupuestos, sino de facilitarle y hacerle más severo, más minucioso. Por eso el Ministerio no opuso la menor dificultad: ahora el Estamento es el que debe decidir cómo se ha de proceder al examen de todas las partes de esta ley. El Ministerio, que no desea más que el orden, y que se entre en el camino legal, quedará satisfecho por su parte siempre que se marche en derechura al fin; los pormenores los abandona, como debe, a la sabiduría del Estamento.

El Sr. Marqués de MONTEVIRGEN: Para deshacer una equivocación que creo ha padecido el Sr. Secretario del Despacho, debo decir que las antiguas Cortes cuando votaban los presupuestos, no esperaban la sanción Real. Aquí tampoco, porque desde el momento en que quedan votados, la Corona se halla autorizada para cobralos: no hay pues sanción Real a mi modo de entender. Además, habiéndose aludido a lo que se verifica en otros países, no veo tampoco esa sanción Real; pues aprobados los presupuestos por las Cámaras de Comunes y Lores, vuelven a la Corona, la cual les da gracias; pero no sanciona. Esta es la práctica, según tengo entendido, y por eso he rectificado esa equivocación, agradeciendo al Sr. Secretario el favor que ne ha hecho en su discurso respecto a mi intención.

El Sr. Secretario del Despacho de ESTADO: Respecto a la intención del Sr. Marqués de Montevirgen, no ha sido favor, sino justicia la que he hecho. Por lo demás, el Estamento me permitirá le distraiga cortos minutos para clarar un hecho. Es cierto en las antiguas Cortes de Castilla no había sanción para los presupuestos; pero tampoco la había para las demás leyes: las Cortes hacían peticiones al Rey: este las mandaba examinar; y por lo regular al acabarse las sesiones solía decir si las admitía o no: pero no había la formalidad de la sanción. Ahora, según el Estatuto Real, esta sanción es necesaria por dos razones sencillas: primera, porque la Corona tiene una parte del poder legislativo, y si no fuera indispensable su sanción, podría verse despojada de aquella participación esencialísima; pues suponiendo que las Cortes variasen enteramente los presupuestos y el sistema de contribuciones, ¿qué le quedaba a la Corona de su prerrogativa? Segunda razón: la sanción se comprende bajo la fórmula: sanciono y ejecútese; es decir, que para que tengan fuerza las leyes deben estar sancionadas por la potestad Real, y no puede disponerse la ejecución sin este requisito, ni las autoridades podrán hacerlas ejecutar, ni los pueblos estarán obligados a obedecerlas. El efecto de la sanción no es otro que el de dar vida a lo mandado, y en todas partes donde hay Gobierno representativo, semejante al nuestro, se exige este requisito. En el art. 40 de la Carta francesa se establece este principio, y expresamente para los presupuestos, pues dice que 'ningún impuesto podrá ser obligatorio si no se halla reconocido por las Cámaras y sancionado por el Rey'. Lo mismo se verifica en Inglaterra, aunque bajo distinta forma.

El Sr. Marqués de MONTEVIRGEN: En vista de lo que acaba de decir S.S., me ocurre una dificultad, que desearía se allanase. ¿Puede la Corona desechar las contribuciones votadas, aumentadas, disminuirlas o no conformarse con ellas? La sanción Real es una autorización; ¿cómo ha de proceder la Corona cuando si se presenta un presupuesto de 1500 millones, por ejemplo, las Cortes lo reduzcan a solo 1000 ? Esta dificultad desearía yo se solventase; pues siendo el acto más solemne de los Estamentos el votar las contribuciones, conviene no dejarla en el aire. En cuanto a la referencia hecha por S.S. de la Cámara francesa, estoy conforme; pero me parece no sucede lo mismo en Inglaterra.

El Sr. Scretario del Despacho de HACIENDA: Me levanto para deshacer meramente una objeción, a mi parecer infundada. ¿Cómo el poder Real podría negar la sanción de los presupuestos? ¿Cómo ha de negar la sanción de esta materia después de discutida en Cortes? Hay cuestiones que llegando a cierto punto son insolubles, y solo se pueden contestar con otras que no 
lo son menos. $\mathrm{Y}$ así diría yo al Sr. Marqués de Montevirgen: ¿Qué haría la Corona si las Cortes negasen los subsidios para pagar al ejército?. Me parece que S.S. no dejará de tener dificultad para contestar a esta réplica mía, como el Ministerio para responder a su pregunta."

(42) Vid. Argüelles, Agustín de, en op. cit., pág. 123.

(43) Vid. idem, págs. 123-124.

(44) Vid. idem, pág. 125.

(45) Vid. idem, págs. 126-127

(46) Vid. idem, pág. 88. 


\title{
COMPROMISSUM. CONTENIDO
}

(SEGUNDA PARTE)

\author{
PR. DR. JESUS DAZA \\ Catedrático de Derecho Romano
}

\section{CONTENIDO}

\subsection{Nombramiento del árbitro}

El compromissum contiene básicamente una serie de elementos fundamentales, el principal de los cuales es el nombramiento del árbitro; otro era la determinación del objeto del mismo y, por último, y aunque no era imprescindible, debía constar el tiempo y el lugar del arbitraje.

En primer lugar es importante señalar las causas que se aducen en orden a determinar la incapacidad para ejercer como arbiter. La primera de ellas es que la condición de esclavo imposibilita a una persona para ello, tal como se lee en el siguiente pasaje de Ulpiano.

Pedius libro nono et Pomponius libro trigésimo tertio scribunt, parvi referre, ingenuus quis, an libertinus sit, integrae famae quis sit arbiter, an ignominiosus. In servum Labeo compromitti non posse libro undecimo scribit et est verum (149).

Sin embargo, el propio Ulpiano precisa más adelante que si el compromiso se contrajera a favor de un esclavo, y una vez hecho libre hubiera pronunciado la sentencia, ésta es válida (si lo hubiera hecho siendo ya libre) consentientibus partibus (150). Se supone, pues, que una estipulación que inicialmente no tenía validez queda convalidada al desaparecer la causa de la misma; tal como piensa Talamanca (151), habría que hablar más bien de una convalidación de la conventio que es previa a la estipulación (152).

Otro supuesto de incapacidad se refiere a personas como el pupilo, el loco, el sordo o el mudo. Ulpiano recoge el testimonio de Pomponio diciendo:

Sed neque in pupillum, neque in furiosum, aut surdum, aut mutum compromittetur, ut Pomponius libro trigésimo tertio scribit (153).

A propósito del menor de veinte años, se conserva en el Digesto un fragmento de Calístrato en el que se dice que la lex Iulia había establecido que no fuera obligado a juzgar, por lo que se concluía lo siguiente:

ideoque poena ex sententia eius nullo modo committitur (154).

Pero inmediatamente se añade que fueron muchos los que dijeron que por esta causa se ha de auxiliar al mayor de veinte años, si fuera menor de veinticinco, cuando temerariamente hubiera aceptado el conocimiento del asunto. Las palabras textuales que se usan son éstas:

Maiori tamen viginti annis, si minor viginti quinque annis sit, ex hac causa sucurrendum, si temere auditorium receperit, multi dixerunt (155). 
El cargo que se ocupa es otra de las causas que puede imposibilitar la función arbitral. Explìcitamente afirma Ulpiano que si uno fuera juez le está prohibido por la lex Iulia que admita la facultad arbitral sobre el negocio de que es juez, o que mande que se contraiga el compromiso a su favor. En caso de que hubiera pronunciado sentencia no se ha de conceder la persecución de la pena:

Si quis iudex sit, arbitrium recipere eius rei, de qua iudex est, inve se compromitti iubere prohibetur lege Iulia, et, si sententiam dixerit, non est danda poenae persecutio (156).

Hay que hacer también referencia a algunos textos relativos a los magistrados en los que aparecen particularidades dignas de relieve. Refiriéndose explícitamente a las personas de los árbitros, Ulpiano afirma que el pretor obligará al árbitro, de cualquier dignidad, aunque sea Consular, a desempeñar el cargo que hubiera aceptado, a no ser quizá que estuviera colocado en alguna Magistratura o potestad (nisi forte sit in aliquo Magistratu positus vel potestate), siendo acaso cónsul o pretor, porque sobre éste no tiene poder (quoniam in hoc imperium non habet). El alcance de esta afirmación debe matizarse teniendo presente lo que inmediatamente se afirma en un pasaje de Paulo:

Nam magistratus superiore aut pari imperio nullo modo possunt cogi; nec interest, ante, an ipso Magistratu arbitrium susceperint; inferiores possunt cogi (157).

Volviendo a las causas de incapacidad, hay que hacer referencia a la condición de la mujer, a causa de su inferioridad y otras razones que apuntan los juristas en las diferentes épocas de la Historia romana. Piénsese, por ejemplo, en la animi levitas a que alude Gayo (158) o a la infirmitas sexus de Ulpiano (159). Este mismo jurista añade una razón relacionada directamente con la incapacidad de la mujer para actuar como juez, a saber, propter forensiam ignorantiam (160). Más explícitamente Paulo llegará a afirmar lo siguiente:

Non autem omnes iudices dari possunt ab is qui iudicis dandi ius habent: quidam enim lege impediuntur ne iudices sint, quidam natura, quidam moribus. Natura, ut surdus mutus: et perpetuo furiosus et impudes, quia iudicio carent... Moribus feminae et servi, non quia non habent iudicium, sed quia receptum est, ut civilibus officiis non fungantur (161).

En una conocida constitución de Justiniano, que constituye un punto obligado de referencia al explicar la incapacidad de la mujer, se establece de forma clara lo siguiente:

Sancimus mulieres suae pudicitiae memores et operum, quae eis natura jermisit et a quibus eas iussit abstinere, licet summae atque optimae opinionis constitutae arbitrium in se susceperint vel, si fuerint patronae, inter libertos suam interposuerint audientiam, ab omni iudiciali agmine separari, ut ex earum electione nulla poena, nulla pacti exceptio adversus iustos eorum conventores habeatur (162).

Aparte de los supuestos de incapacidad, las fuentes aluden a algunas cualidades 
de tipo moral que pueden condicionar la actividad y decisión última del árbitro. He aquí como Ulpiano alude a esta idea en dos pasajes de sus Comentarios al Edicto:

Pedius libro nono et Pomponius libro trigesimo tertio scribunt parvi referre, ingenuus quis an libertinus sit, integrae famae quis sit arbiter an ignominiosus. In servum Labeo compromitti non posse libro undecimo scribit: et est verum (163). Sunt et alii, qui non coguntur sententiam dicere, ut puta si sordes aut turpitudo arbitri manifesta sit (164).

Mientras algunos romanistas (165) entienden que en los textos se alude a una recusación que formulan las partes, otros, como Talamanca (166), piensan que Ulpiano, en el primero de los pasajes citados, se refiere a los presupuestos de admisibilidad de la coacción pretoria. La causa de exclusión de la coercitio invalida el compromissum. El propio Talamanca aduce, para confirmar su punto de vista e interpretar los textos a que hemos hecho referencia, una constitución de los emperadores Diocleciano y Maximiano. Dirigiéndose a Petronio le dicen, en síntesis, que no sometiéndose a las sentencias de los árbitros nombrados en el compromiso, si medió venalidad o evidente favor de los que fueron árbitros, podrá usar de la excepción de dolo malo (exceptione doli mali uti poterit) contra su hija que haya ejercitado la acción de lo estipulado (agentem ex stipulatu). Y añade que tampoco se le prohibirá demandar a su hija en virtud de la cláusula de dolo que suele agregarse a la estipulación del compromiso. He aquí las palabras textuales de los emperadores:

Arbitrorum ex compromisso sententiare non obtemperans, si sordes vel evidens gratia eorum, qui arbitrati sunt, intercessit, adversum filiam suam agentem ex stipulatu exceptione doli mali uti poteris. Sed et ex doli clausula, quae compromissi stipulationi subiici solet, filiam tuam convenire non vetaberis (167).

Este planteamiento es básicamente coincidente con el de Paulo, tal como se manifiesta en otro pasaje del Digesto que recoge sus Comentarios al Edicto. Según él, cuando uno de los árbitros hubiera aparecido siendo manifiestamente enemigo por otras causas, y reconvenido con las pruebas para que no pronunciase sentencia hubiera perseverado en su decisión de pronunciarla, sin que nadie le apremiara, el emperador Antonino proveyó al libelo de uno que se querelló de eso, que podía usar de la excepción de dolo malo (...posse eum uti doli mali exceptione). El mismo emperador, habiendo sido consultado por un juez, ante quien se pedía la pena, respondió por rescripto que, aunque no puede apelarse, deberá obstar en la petición de la pena la doli mali exceptio. Así pues, por medio de esta excepción hay cierta especie de apelación (quaedam appelandi species est), en cuanto que es lícito revocar la sentencia del árbitro. He aqui las palabras literales con las que se expresa Paulo:

Quum quidam arbiter ex aliis causis inimicus manifeste apparuisset, testationibus etiam conventus, ne sententiam diceret, nihilominus nullo cogente dicere perseverasset, libello cuiusdam id querentis Imperator Antoninus subscripsit, posse eum uti doli mali exceptione. Et idem, quam a iudice consuleretur, apud quem poena petebatur, res- 
cripsit, etiam si apellari non potest, doli mali exceptionem in poena petitione obstaturam. Per hanc ergo exceptionem quaedam appellandi species est, quum liceat retractare de sententia arbitri (168).

Finalmente, hay que tener presente entre las causas de excusa en el arbitraje, otras que señala Ulpiano y que son fundamentalmente éstas: a) difamación del árbitro por parte de los litigantes; $b$ ) el hecho de que hubieran sobrevenido inimicitiae capitales inter eum et litigatores; c) el supuesto de la enfermedad, o la necesidad de ocuparse en negocios propios, o exigencias de algún cargo de la República, que le dispensaban de su cometido (169).

A propósito de la enfermedad, citada por Ulpiano como un motivo de excusa (excusationem recipere), hay que observar que Paulo veía únicamente en ella una causa para su aplazamiento:

Et si qua alia incommoditas ei post arbitrium susceptum incidat. Sed in causa valetudinis similibusve causa cognita diferre cogitur (170).

Probablemente la diferencia de opiniones entre los juristas se debe al hecho de que con el término morbus se indicaba únicamente un tipo de enfermedad pasajera, lo que justificaría el aplazamiento, mientras que con el término valetudo se aludía a un estado de mala salud que se suponía duradero y que justificaba la excusa.

Aparte del análisis de los supuestos de incapacidad para desempeñar el cargo de ábitro, hay que hacer también referencia al hecho de que debía determinarse claramente la persona que era elegida como tal:

In compromissis arbitrium personae insertum personam non egredi$\operatorname{tur}(171)$.

Los textos de las fuentes parecen favorecer la opinión de quienes, como Matthiass, entienden que pueden distinguirse diversos supuestos en la determinación del árbitro. En unos casos, su elección correría a cargo de un tercero (arbitrium boni viri); en otros, deciden que una de las partes elegirá al árbitro, o bien lo harán las dos; finalmente, ambas partes declaran que el árbitro será aquella persona que de común acuerdo decidan posteriormente (172).

Hay que observar que cuando se habla de la determinación del árbitro no necesariamente se hace referencia sólo a una persona, ya que, como explícitamente señala Ulpiano, pueden ser varios los que aceptaron el arbitraje (si plures sunt, qui arbitrium receperunt). En este caso, añade el jurista, ninguno de ellos deberá ser obligado a pronunciar sentencia por sí mismo, sino que la obligación incumbe a todos (nemo unus cogendus erit sententiam dicere, sed aut omnes, aut nullus) (173).

A modo de ilustración de esta forma de proceder, es significativo, por ejemplo, el supuesto a que se alude en un pasaje de Ulpiano a propósito de un compromiso contraído alternativamente en favor de dos personas:

Sed si ita sit compromissum, arbitratu Titii, aut Seii fieri, Pomponius scribit, et nos putamus compromissum valere; sed is erit cogendus sententiam dicere, in quem litigatores consenserint (174). 
Un fragmento de Pomponio plantea el supuesto de pluralidad de árbitros cuando la sentencia ha de dictarse por acuerdo entre todos ellos. Según él, así como nombrados tres jueces, no es válido lo que de común acuerdo juzgaron dos estando ausente el tercero, porque sólo es válido lo que juzgue la mayoría de todos, cuando es evidente que todos juzgaron:

Sicuti tribus iudicibus datis quod duo ex consensu absente tertio iudicaverunt, nihil valet, quia id demum, quod maior pars omnium iudicavit, ratum est, quam et omnes iudicasse palam est (175).

En el caso de que fueran únicamente dos los árbitros elegidos, el problema que se planteaba a la hora de dictar sentencia era evidente cuando existía desacuerdo entre ellos, ya que no existía una opinión mayoritaria entre ellos. De ahí que en los fragmentos de los juristas se encuentren diferentes supuestos que deben ser examinados. Un texto de Ulpiano dice que si se hubiera contraído compromiso a favor de dos de forma que, si disintieran, elijan a un tercero, tal compromiso no vale (puto talem compromissum non valere), puesto que al elegirlo pueden disentir. Pero si el tercer ábitro fue fijado desde el principio el compromiso es válido, puesto que no pueden disentir en la elección (176).

Sin embargo, el propio Ulpiano, en otro pasaje, sienta una doctrina que parece contradecir al planteamiento anterior. El pasaje en cuestión es:

Principaliter tamen quaeramus, si in duos arbitros sit compromissum, an cogere eos Praetor debeat sententiam dicere, quia res fere sine exitu futura est propter naturalem hominum ad dissentiendum facilitatem. In impari enim numero idcirco compromissum admittitur, non quoniam consentire omnes facile est, sed quia etsi dissentiant, invenitur pars maior, cuius arbitrio stabitur. Sed usitatum est etiam in duos compromitti, et debet Praetor cogere arbitros, si non consentiant, tertiam certam eligere personam, cuius auctoritati pareatur (177).

En efecto, los romanistas difieren a la hora de interpretar la posición mantenida por Ulpiano en el pasaje anterior y en éste. En unos casos se piensa que el segundo es una paráfrasis del anterior, de modo que no se haría referencia a dos supuestos distintos, como opinan otros. La diferencia estaría en que D. 4, 8, 17, 5 ofrece unas soluciones que tienen su origen en la voluntad de las partes, habiendo previsto los problemas que podrían plantearse en caso de desacuerdo, mientras que en D. 4, 8 , 17, 6 no está prevista la posibilidad de desacuerdo, por lo que el Pretor deberá elegir la persona que dicte la sentencia definitiva. Esta persona, que decide el conflicto, es considerada por algunos romanistas no como árbitro dirimente, sino que decidiría con independencia de los otros, mientras que otros opinan que su intervención serviría únicamente para conseguir una opinión mayoritaria que pudiera dirimir el conflicto (178).

La misma diferencia de posición se mantiene a propósito de si este nuevo árbitro es verdaderamente tal o debe ser considerado un juez, tal como piensa entre otros, Marrone (179). Algunos autores entienden que su cualidad de árbitro podría inferirse del siguiente fragmento de Ulpiano: 
Si arbiter iussit, puta in provincia adesse litigatores, quum Romae esset in eum compromissum, an ei impune non pareatur, quaeritur. Quod Iulianus ait libro quarto, cum locum compromissi inesse, de quo actum sit, ut promitteretur. Impune igitur ei non parebitur, si alio loci adesse iusserit, Quid ergo, si non appareat, de quo locum actum sit? Melius dicetur, eum locum contineri, ubi compromissum est. Quid tamen, si in eo loco, qui sit circa Urbem, adesse iusserit? Pegasus admittit, valere iussum. Quod puto ito verum esse, si et eius sit auctoritatis arbiter, ut in secessibus soleat agere, et litigatores facile eo loci venire possint $(180)$.

\subsection{Objeto del compromiso}

El Estado romano, como los Estados modernos, se reserva una serie de acciones, que jamás abandona al capricho de los individuos y por ello prohíbe que puedan ser objeto de compromiso (181). Ésta es la razón por la que Paulo en el libro 13 de sus Comentarios al Edicto escribe que, si por error se acude al árbitro para que dicte sentencia de famoso delicto, el Pretor debe prohibir su pronunciamiento:

Iulianus indistincte scribit: si per errorem de famoso delicto ad arbitrum itum est, vel de ea re, de qua publicum iudicium sit constitutum, veluti de adulteriis, sicariis, et similibus, vetare debet Praetor sententiam dicere, nec dare dictae exsecutionem (182).

Insiste en su idea, cuando a continuación afirma que ante un compromiso formalizado y referido a una cuestión relativa a la libertad, el árbitro no debe ser compelido a dictar sentencia, pues es privilegio de los que han obtenido la libertad gozar del dictamen de jueces superiores:

De liberali causa compromisso facto recte non compelletur arbiter sententiam dicere, quia favor libertatis est, ut maiores iudices habere debeat. Eadem dicenda sunt, sive de ingenuitate, sive de libertinitate quaestio sit, et si ex fideicommissi causa libertas deberi dicatur. Idem dicendum est in populari actione (183).

Entre las acciones que el Estado prohibía someter a compromissum podemos señalar las siguientes:

- las acciones penales que entrañan infamia,

- aquellas sobre las que se constituye un iudicium publicum,

- las acciones populares,

- las cuestiones de estado,

- la in integrum restitutio,

- distintas acciones: actio tutelae, fideicomisos de libertad, etc.

Para su mejor comprensión explicaremos a continuación cada uno de estos grupos e investigaremos las razones que los han excluido del compromissum.

\subsubsection{Acciones penales que entrañan infamia:}

Para hablar de estas acciones es necesario que el hecho sea un delito, y que este delito entrañe infamia; esto excluye: $1^{\circ}$ que todas las acciones penales entrañen infa- 
mia, como la actio quod metus causa, la actio legis Aquiliae; $2^{\circ}$ toda acción que nace ex contractu, por ejemplo, las acciones de dolo, pro socio, mandati, depositi, y en el antiguo Derecho romano, el contrato de fiducia (184). Para estas últimas no sólo no prohibió el uso del compromiso o de la transacción, sino que era favorable al uso de estos medios con el fin de evitar la acción y, consiguientemente, la infamia que quedó unida a estas acciones como un recuerdo de su antiguo carácter penal. Prueba de esta tendencia del Pretor a evitar la aplicación de la infamia la tenemos en el carácter subsidiario que concede a la actio de dolo.

El compromiso, sin duda alguna, constituía el medio más natural de zanjar las diferencias entre aquellas personas a las que no era posible intentar entre sí más que acciones infamantes. Si, con ocasión de un delito, nacían varias acciones, unas penales e infamantes y otras carentes de alguno de estos dos requisitos, el Pretor dejaba libertad para comprometerse sobre estas últimas. Un ejemplo de ello lo tenemos en el hecho de que cuando se prohibió el compromiso sobre la actio furti nada impedía hacerlo en lo que concierne a la condictio furtiva.

Hay que añadir que el que se prohíba utilizar el compromiso para aquellos delitos que entrañan infamia, no significa que sea obligatorio acudir a la jurisdicción ordinaria. Es más, las personas que habían sido víctimas de una injuria y que estaban defendidas por la actio iniuriarum eran libres de perdonar y no utilizarla. Lo único que la ley pretendía era que estas acciones fueran interpuestas ante los jueces y no ante los árbitros. Esto, en el derecho moderno, es fácil de entender, ya que la persecución del delito es independiente de la víctima, y se confía a un magistrado que obra en nombre del Estado, cuyo orden y paz han sido turbados por el acto delictivo. En Derecho romano, sin embargo, es más difícil de entender el que la víctima dueña de la acción y libre de ejercitarla o de perderla, pueda ser obligada a hacerlo ante el juez, una vez que se decide a efectuar su defensa, y no se le dé opción a elegir entre un sistema u otro, siendo como es mucho más amplio el poder que se le concede a la víctima de no perseguir, si no quiere, al culpable. Quizá se deba a que estas soluciones tan llamativas apenas se deban en la práctica. El olvido de la injuria o del daño debía ser raro, sobre todo, cuando se estaba en presencia de acciones dadas al triple $\mathrm{o}$ al cuádruple, ya que eran demasiado tentadoras para dejarlas de ejercitar. Además el Pretor encontraba, es posible, un menor escándalo en el completo olvido de la injuria que en un compromiso que revelaría necesariamente el delito, sin acarrear la pérdida legal fijada a la condena por un juez.

\subsubsection{Iudicia pública:}

Hay que tener presente que en la terminología romana se distinguían los delicta, o hechos ilícitos que daba lugar al proceso privado, y los crimina o delitos considerados públicos, a los que se aplicaban las diferentes normas del ius publicum. Lo importante es que ambos órdenes de hechos tenían como desenlace la pena.

Esto supuesto, es evidente que el Derecho criminal fue evolucionando al mismo tiempo que lo hacía la forma del proceso o modo de represión de los crimina. Durante la época arcaica, cuando las concepciones religiosas tenían una incidencia directa en la vida romana, el ordenamiento ciudadano justificaba su sanción basán- 
dose en ellas y considerando sacrílego al culpable. Al final de la monarquía, a medida que el Estado va afirmando su autoridad laica, se modifica también el sistema de represión penal.

Con el fin de reprimir las repetundae, esto es, los abusos, apropiaciones indebidas y malversaciones de los magistrados, especialmente en las Provincias, se crearon tribunales extraordinarios (quaestiones extraordinariae), que inicialmente estaban dirigidas por cónsules y, a partir del siglo II a. C., por un pretor. La primera ley que establece este procedimiento de forma regular fue la lex Calpurnia repetundarum (año 149 a. C.), seguida luego por la lex Acilia (año 123 a. C.), que permite conocer detalles importantes sobre la organización del proceso (185). Al hacerse permanentes estos tribunales, a partir de la época de los Gracos, recibieron el nombre de quaestiones perpetuae. Más adelante se iría extendiendo su competencia a diferentes clases de crimina.

Las leyes sobre los iudicia publica se relacionan en su mayoría con los nombres de Syla, de César o de Augusto. Ellas dotaron, por primera vez, al Derecho romano de reglas precisas en materia criminal, poniendo fin a la antigua práctica que permitía a los comicios, crear, en cada circunstancia, el crimen y la pena.

Estos tribunales estaban compuestos por un jurado y el pretor que los presidía y, en su defecto, por un iudex quaestionis. El procedimiento era acusatorio, pero el acusador actuaba como ciudadano, y no como particular. Los romanos no habían admitido que la acción criminal pudiera ser utilizada en interés privado. El acusador nada tenía que ganar ni que perder; sin embargo, posteriormente, cuando disminuyó el celo cívico, se concedía como incentivo una parte de la multa; pero esto se hacía fuera del proceso. Éste se iniciaba con la postulatio o la petición al magistrado del comienzo de la actuación. Se procedía luego a la nominis delatio o acusación formal, que era aceptada por el magistrado (nomen recipere). Una vez compuesto el jurado, se celebraba el debate, presidido por el Pretor que, por último, daba a conocer el resultado de las votaciones secretas de los componentes de ese jurado. Las sentencias no estaban sujetas a revisión. Más tarde, avanzada ya la época imperial, era posible el recurso al emperador, o appellatio, en determinados casos (186).

Teniendo presente lo expuesto anteriormente es fácil entender por qué el Pretor prohibió que semejante materia fuera objeto de compromiso. Se trata de delitos entendidos en el sentido del Derecho moderno.

Durante la época de Augusto, a quien se deben varias leyes especiales y una general (lex iudiciorum publicorum), se reorganiza el procedimiento y se amplía el Derecho penal, que abarca fundamentalmente una serie de crimina (187). Estos crimina unos eran políticos, como la perduellio, cuando se atacaba directamente a la cosa pública (188); otros, como el homicidium, eran los más susceptibles de perturbar la seguridad (189) y , finalmente, otros se consideraban ultrajes a las costumbres, cuya represión el Estado había arrebatado de las manos débiles de las autoridades familiares, guardianes legales, hasta el presente, de las costumbres privadas.

En esta época de la historia de Roma se comprende que sobre estas cuestiones no pueda existir un juicio puramente privado. Sin duda el acusador sería un simple ciudadano autorizado e incluso elegido, en algunas ocasiones, por el propio Pretor. 
Ésta era una consecuencia del espíritu que reinaba en las repúblicas antiguas. Todo ciudadano, siendo una parte del Estado que le absorbía, podía representarlo contra sus enemigos; y el culpable era un encmigo del Estado. Es, pues, el carácter intrínseco de los hechos de que se trata lo que no permite que puedan ser objeto de un arbitraje (190). Comprometer sobre una de estas acciones hubiera sido, por lo que respecta a un ciudadano, una verdadera usurpación, ya que esta acción no formaba parte de su patrimonio; sería tanto como violar aquel principio que prohíbe bajo pena que se obliguen las partes a no hacer aquello que la ley impone como deber. Todo lo que acabamos de exponer sobre la iudicia publica es válido en el Imperio, pero a principios del siglo III, desaparecidas las Quaestiones perpetuae, el régimen de represión criminal queda unificado en el sistema de la cognitio, acentuándose la tendencia a ser aplicado un único sistema procesal, tanto a las cuestiones penales, como a las civiles (191).

\subsubsection{Acciones populares:}

Eran acciones civiles susceptibles de ser ejercitadas por cualquier ciudadano. Estas acciones son concedidas, en primer lugar, a quien resulta lesionado o a quien tiene un interés directo; si nadie quiere o puede ejercerlas, se conceden a cualquier ciudadano (en caso de que varias personas pidan a un mismo tiempo actuar con una actio pública, el magistrado elige al más idóneo).

Ahora bien, en la época antigua, cuando la gens estaba fuertemente constituida, esta acción aseguraba absolutamente su fin. Los miembros de la gens no dejaban de perseguir los crímenes de los que uno de los suyos había sido víctima.

Otro grupo de acciones populares se refería a los delitos cometidos contra la cosa pública (v. c.: la actio ex albo corrupto) (192). Ulpiano habla de ella, cuando escribe que se debe dar acción por quinientos aureos contra el que hubiera alterado con dolo malo lo que se hubiera puesto en un album o en una carta:

Si quis id, quod iurisdictionis perpetuae causa, non quod, prout res incidit, in albo, vel in charta, vel in alia materia propositum erit, dolo malo corruperit, datur in eum quingentorum aureorum iudicium, quod populare est (193).

Estos eran los recursos del Pretor en una época en la que el derecho penal estaba en sus comienzos. Se remitía a cada ciudadano, obligado a vigilar la conservación del Estado, la necesidad de perseguir aquellos delitos de los que él tenía conocimiento. Este procedimiento se aplicaría, sobre todo, a aquellos delitos que su frecuencia y su gravedad secundaria no permitían someter a los comicios. La actio de sepulcro violato, la actio de libertate, la actio peculatus eran acciones populares, antes de ser objeto de un iudicium publicum. No se puede admitir, como acertadamente afirma Declareuil, que el ciudadano pueda traficar con estas acciones en interés personal y el derecho no permite comprometerse a no hacer lo que el deber de ciudadano impone, a saber, perseguir al culpable (194).

\subsubsection{Cuestiones de Estado}

La situación que una persona ocupa en la familia y en el Estado es una cosa demasiado importante para abandonarla al juicio de un árbitro. El Derecho romano 
ha querido que estas cuestiones fuesen solventadas con la intervención de magistrados superiores (maiores iudices):

De liberali causa compromisso facto recte non compelletur arbiter sententiam dicere, quia favor libertatis est, ut maiores iudices habere debeat. Eadem dicenda sunt, sive de ingenuitate sive de libertinitate quaestio sit... (195).

La libertad no puede ser objeto de un compromiso, como tampoco pueden serlo la ingenuidad o la cualidad de libre. El Pretor solamente podía conocer de ellas con los cónsules; más tarde se creó un Pretor especial, el praetor liberalis. En las provincias, los praesides podían conocer también de estas cuestiones cuando estaban revestidos del ius praetorium o del ius consulare (196). La imposibilidad de que los iudices pedanei intervinieran en estas causas está recogida en el Codex (197).

Es fácil de comprender por qué estas cuestiones de estado no pueden ser objeto de compromiso; ya que además de su importancia, nada sería más fácil que encontrar un adversario complaciente que no hubiera sido más que una comparsa, permitiendo formar una apariencia de compromiso en base a la cual un árbitro hubiera atribuido a una persona un estado que no era el suyo (198).

\subsubsection{Restitutiones in integrum}

Justiniano, en una constitución recogida en el Codex, dice que para quitar toda suerte de dudas, prohíbe comprometer sobre las cuestiones de restitutio in integrum. Es difícil de entender esta intención justinianea ya que, en esta materia, no hace ninguna innovación. Si, en su tiempo, existían casos de in integrum restitutio sometidos a un procedimiento arbitral, esto se hacía violando todos los principios establecidos. Solamente tendrán facultades para juzgar estas causas los que fueron nombrados para un cargo administrativo al que sea inherente la jurisdicción:

Quum scimus, esse dubitatum de restitutionibus, quae in integrum postulantur, sive tamtummodo apud iudicem, cui aliqua iurisdictio est, examinari eas oportet, sive et apud pedaneos... Sed ne quis ita effuse intellectum nostrae constitutionis audeat esse tradendum, ut etiam apud compromissarios iudices, vel arbitros ex communi sententia electos, vel apud eos, qui dantur a iudicibus, qui propriam iurisdictionem non habent, sed tantummodo iudicandi facultatem, putet huiusmodi extendi sanctionem, quum hos generaliter volumus tales causas dirimere, qui vel certae administrationi, cui et iurisdictio adhaeret, praespositi sunt, vel ab his fuerint dati, et multo magis si a nostra maiestate delegata eis sit causarum audientia... (199).

La misma naturaleza de la restitutio in integrum prohibía que ésta emanara de una sentencia arbitral. $\mathrm{La}$ in integrum restitutio se caracteriza por la necesidad de una cognita causa; y eso, cuando sea autorizada por el edicto (200). Era concedida inmediatamente por el magistrado superior, pretor o presidente de provincia. Cuando una demanda de restitución se presentaba incidentalmente en un proceso, el iudex nombrado por el pretor, no podía conocer de ella; las partes deberían acudir 
nuevamente delante del pretor. Bajo el Imperio, el emperador y los prefectus urbi et praetorii son los que conocen de estas cuestiones, pero nunca lo hicieron los magistrados inferiores. Se entiende que los árbitros ex compromisso no pudieran pronunciarse sobre estas cuestiones. Teniendo en cuenta el alcance de la restitutio in integrum, capaz de destruir una relación jurídica creada por la ley, es lógico que se impida a los jueces particulares pronunciarse sobre ella. A partir de Justiniano es cuando los magistrados, anteriormente mencionados, fueron autorizados a delegar en los jueces la instrucción y el conocimiento de estas causas. Evidentemente, jamás una cuestión de este género pudo ser objeto de compromiso.

\subsubsection{Fideicomisos}

Paulo, en el libro XIII de sus Comentarios al edicto afirma la imposibilidad de someter el fideicomiso de libertad a un compromiso (201). Ello se debía a dos razones: a) una cuestión de estado estaba en juego; b) era una regla común a todos los fideicomisos.

Esta forma de disposición testamentaria, que obtuvo una plaza en Derecho romano, se la admitió por favor, sometiéndola a la supervisión de los magistrados superiores (202). Augusto creó una pretura especial. Declareuil afirma, a este propósito, que todo fideicomiso da lugar a una persecutio, es decir, que el magistrado es quien decide directamente sobre el asunto en lugar de emitir la fórrnula y enviársela al juez. Esta diferencia hubiera bastado para hacer comprender a las partes que no era posible comprometarse sobre tales cuestiones, pero tal diferencia desapareció con el procedimiento formulario (203). En Roma, el magistrado decidía habitualmente las cuestiones de fideicomisos, y también en las provincias, en la época de los conventus. El texto del Digesto, por tanto, no limita, pero induce a sospechar, a primera vista, que el fideicommissum libertatis era el único que no podía ser sometido a un arbiter ex compromisso.

\subsubsection{Actio tutelae}

La duda que surge respecto a estas acciones se debe a la diferencia de redacción que encontramos entre el Digesto y los Básilicos (204); mientras que en aquél se lee: idem dicendum est, in populari actione (205), en los Básilicos hallamos una lectura diferente: peri poupilarias agones, esto es, "es preciso decir lo mismo sobre la actio de tutela". Sin embargo, esto no puede anular lo dicho anteriormente a propósito de las acciones populares; porque si bien queda claro que no pueden ser objeto de un compromiso, también es verdad que los principios expuestos en estos textos no son en modo alguno restrictivos. No puede aceptarse que de los Básilicos resulte la imposibilidad de someter la actio tutelae a un compromiso; se trata, más bien, de una acción civil, y sabemos que las acciones civiles, incluso infamantes, pueden ser sometidas a un arbiter ex compromisso. Habría habido una excepción para la actio tutelae, en razón de la voluntad de favorecer al pupilo, y también de la influencia que su antiguo tutor podría ejercer sobre él, con el fin de imponerle un compromiso en que él sería incapaz de mantener sus intereses. Esto es posible, en cuanto que Ulpiano afirma textualmente, citando a Labeón, lo siguiente: 
Si compromisso facto sententia dicta est, quo quis a minore viginti quinque annis tutelae absolveretur ratum id a praetore non habendum, neque penae eo nomine commissae petitionem dari (206).

Algunos comentaristas entienden que las palabras ratum non habendum se refieren a una in integrum restitutio, no a una nulidad absoluta del compromiso, como piensan otros. Declareuil observa, por su parte, que el texto, tomado en sí mismo, parece más favorable a esta segunda interpretación, en cuanto que se deduce de él que el pretor se encuentra en la obligación de no ratificar el compromiso y de negar la actio poenae. De ahí surge una duda, de modo que la cuestión parece insoluble. Algunos piensan que la versión de los Basílicos es un error, aunque los comentadores griegos la admiten unánimemente. Según observa el mismo Declareuil (207), es posible que la actio tutelae, que fue originariamente una acción de delito, hubiera conservado posteriormente, junto con el carácter infamante, el de no poder ser objeto de un compromiso, aunque reconoce que es difícil llegar a establecer una certeza sobre esta cuestión.

El compromiso es imposible igualmente en lo que concierne a los acuerdos que la ley prohíbe o no reconoce. Piénsese, por ejemplo, en los contratos usurarios, o las deudas de juego. Paulo dice, por ejemplo, lo siguiente:

Senatusconsultum vetuit in pecuniam ludere, praeterquam si quis certet hasta vel pilo iaciendo, vel currendo, saliendo, luctando, pugnando, quod virtutis causa fiat (208).

En el caso de la mujer sujeta a tutela, que no podía enajenar sus res mancipi, así como en el caso del pupilo, que no podía enajenar sus praedia rustica, se plantea el problema de si podían o no comprometerse sobre la propiedad de tales bienes. Parece evidente que no les estaba prohibido litigar y ningún texto les prohíbe hacer un compromiso. A propósito de las diferencias entre litigar y "comprometerse", debe observarse que en el compromiso las partes están menos protegidas, y se ven obligadas a velar más intensamente por sus intereses. Por otro lado, cabe preguntarse si no es más fácil encubrir una venta bajo la forma de un compromiso que bajo la instancia judicial. En cualquier caso no existen textos en que pueda apoyarse cualquier juicio fundado. Pero teniendo en cuenta que podía tener como resultado el que el incapaz fuera privado de la propiedad, se considera probable que en estos casos debía considerarse prohibido el compromiso, ya que sería muy fácil eludir la ley estipulando una pena como garantía de una obligación que la ley declara nula.

\subsubsection{Compromissum plenum}

Normalmente el compromisum versaría sobre una controversia, pero era perfectamente válido un compromissum realizado sobre todas las controversias (o algunas de ellas) existentes entre las partes. Ulpiano, en su libro XII de Comentarios al Edicto, afirma:

Plenum compromissum appellatur, quod de rebus controversiisve compositum est, nam ad omnes controversias pertinet... (209). 
Pero, como observa Paulo, un compromiso sobre todas las controversias entre las partes, en modo alguno supone que puedan incluirse las controversias futuras:

De his rebus et rationibus et controversiis iudicare arbiter potest, quae ab initio fuissent inter eos, qui compromiserunt, non quae postea supervenerunt (210).

En el fragmento de Ulpiano (D. 4, 8, 21,6) se plantea un problema cuando se leen las palabras compromissum plenum, ya que éstas no siempre tienen el mismo significado en las fuentes. Del texto y contexto del fragmento se saca la conclusión de que plenum compromissum es aquél que versa sobre la totalidad de las controversias existentes entre las partes (211).

La expresión compromissum plenum la encontramos en otros fragmentos y no está referida al mismo supuesto. De un texto de Ulpiano, que citaremos a continuación, se deduce que compromissum plenum es el que contiene la cláusula de dolo:

...Et ideo, si arbitrum quis corrupit vel pecunia vel ambitione, vel advocatum diversae partis, vel aliquem ex his, quibus causam suam commiserat, ex doli clausula poterit conveniri; vel si adversarium callide circumvenit. Et omnimo si in hac lite dolose versatus est, locum habebit ex stipulatu actio; et ideo, si velit de dolo actionem exercere adversarius, non debebit, quum habeat ex stipulatu actionem. Quodsi huiusmodi clausula in compromisso adscripta non est, tunc de dolo actio vel exceptio locum habebit. Hoc autem compromissum plenum est, quod et doli clausulae habet mentionem (212).

En otro fragmento del Digesto aparece la expresión compromissum plenum con un sentido distinto del de los dos fragmentos anteriores. En ese supuesto compromissum plenum sería aquél en que una de las partes promete como pena una cosa y la otra una cantidad de dinero:

... Quid ergo, si res apud arbitrum depositae sunt eo pacto, ut ei daret, qui vicerit, vel ut eam rem daret, si non pareatur sententiae, an cogendus sit sententiam dicere? et puto cogendum, tantundem, et si quantitas certa ad hoc apud eum deponatur. Proinde et si alter rem, alter pecuniam stipulanti promiserit, plenum compromissum est et cogetur sententiam dicere (213).

Ulpiano, citando a Pomponio, (D. 4, 8, 13, 1), emplea la expresión compromissum plenum con otro significado distinto de los que hemos mencionado:

Nam si ideo, quia de unius controversiis solum compromissum est, nulla ratio est, licet enim et de una re compromittere; si vero ideo, quia ex altera duntaxat parte stipulatio intervenit, est ratio. Quamquam si petitor quis stipulatus est, possit dici, plenum esse compromissum, quia is, qui convenitur, tutus est veluti pacti exceptione; is, qui convenit, si 
arbitro non pareatur, habet stipulationem. Sed id verum esse non puto; neque enim sufficit exceptionem habere, ut arbiter sententiam dicere cogatur.

Estoy de acuerdo con Buigues (214) cuando sostiene que de la lectura de estos textos es imposible deducir una conclusión definitiva sobre el significado de la expresión compromissum plenum. Sorprende, sobremanera, que cuatro textos pertenecientes a Ulpiano y que se contienen en su libro XIII de sus Comentarios al Edicto nos transmitan significados aparentemente tan diferentes de la misma expresión. Creo, pues, que la expresión compromissum plenum no hacía referencia a un compromiso con un contenido específico, sino que lo que el jurista quería expresar con esas palabras, era que el compromiso había sido válido y que podía producir sus efectos.

\subsection{Fijación por las partes de los términos del compromissum}

3.3.1. Siendo la finalidad del compromissum el dirimir extrajudicialmente una controversia, es preciso que las partes determinen con precisión los términos exactos de la misma, estableciendo un programa al cual deba someterse el árbitro y que condiciona últimamente su sentencia. En este sentido, y en expresión de La Pira, el compromissum constituye, para el árbitro, "el paradigma de su juicio" (215).

Tal es el contenido esencial de un conocido pasaje de Paulo en el que se dice textualmente:

De officio arbitri tractantibus sciendum est, omnem tractatum ex ipso compromisso sumendum: nec enim aliud illi licebit, quam quod ibi ut efficere possit, cautum est: non ergo quodlibet statuere arbiter poterit, nec in qua re libet, nisi de qua re compromissum est, et quatenus compromissum est (216).

El contenido esencial de este pasaje es, pues, que el árbitro ha de ajustarse a los términos precisos del compromissum, no teniendo ninguna capacidad para tomar decisiones sobre asuntos que no sean objeto explícito del mismo. Esta misma idea se contiene en otros pasajes del Digesto (217), que al tratar de la prórroga del plazo del compromiso niegan al árbitro cualquier posibilidad de decidir sobre la misma, de modo que si así hiciera, cuando se dicte la sentencia las partes no estarán obligadas a someterse a ella, en el caso de que en el compromissum no constara de forma expresa la posibilidad de que el árbitro decidiera en este sentido.

Wlassak ha analizado ampliamente los pasajes en que se subraya el hecho de que al árbitro ha de ofrecérsele, en el compromissum, un programa preciso al que debe atenerse en el momento de emitir su sentencia (218). Esto no implica, por otra parte, que se condicione al árbitro en relación con el contenido de su decisión, puesto que, evidentemente, ello significaría la nulidad del compromissum. Explícitamente afirma Paulo que si el compromiso se hizo a fin de que el árbitro pronuncie una determinada sentencia, su arbitraje es nulo:

... et ideo si sic fuit in arbitrum compromissum, ut certam setentiam dicat, nullum esse arbitrium (219). 
Tampoco sería válido un compromissum en el que se pidiera al árbitro que dictara sentencia ateniéndose al parecer de otro, puesto que en tal caso carecería de libertad. Remitiéndose al testimonio de Pomponio recuerda Ulpiano la pregunta que aquél se formulaba en estos términos:

... si ita sit compromissum, ut, quod Titio disceptatori placet, id Seius pronuntiet, quis sit cogendus? Et puto tale arbitrium non valere, in quo libera facultas arbitri sententiae non est futura (220).

Por otro lado, cuando las partes decidan nombrar un árbitro para dirimir una controversia en la que están en juego asuntos varios, y no uno sólo, la posibilidad de que el árbitro decida sobre ellos ha de venir ex ipso compromisso, debiendo incluir en él la cláusula de rebus omnibus controversiisve, que pone de manifiesto el acuerdo de las partes en este sentido. He aquí las palabras exactas con las que se refiere Ulpiano a ese supuesto:

Plenum compromissum appellatur, quod de rebus controversiisve compositum est, nam ad omnes controversias pertinet; sed si forte de una re sit disputatio, licet pleno compromisso actum sit, tamen ex ceteris causis actiones superesse; id enim venit in compromissum, de quo actum est, (ut) veniret. Sed est tutius, si quis de certa re compromissum facturus sit, de ea sola exprimi re in compromisso (221).

En el libro I Responsorum, Scévola recoge la posibilidad de que las partes planteen al árbitro un compromiso sobre todos los asuntos pendientes entre ellos:

De rebus controversiisque omnibus compromissum in arbitrum a Lucio Titio et Maevio Sempronio factum est, sed errore quaedam species in petitione a Lucio Titio deductae non sunt, nec arbiter de his quidquam pronuntiavit; quaesitum est, an species omissae peti possint? Respondit, peti posse, nec poenam ex compromisso committi; quod si maligne hoc fecit, petere quidem potest, sed poenae subiugabitur (222).

Del texto se deduce que si, por error, no se han planteado en el acuerdo todos los asuntos pendientes y que las partes pretendían que fueran decididos por el árbitro, era posible reclamar posteriormente, mediante juicio, sobre los asuntos no sentenciados sin incurrir en pena. Es evidente que la vía judicial no se agota por el compromiso, y cabe recurrir sobre lo sentenciado, imputando la pena a la parte que no acató la sentencia.

Hemos podido comprobar con el análisis de los textos que el árbitro queda sometido al compromiso con cierta similitud de lo que sucede con el juez después de la litis contestatio; sin embargo, al árbitro se le reconoce un mayor margen de discrecionalidad frente a la obligatoriedad que la fórmula impone al juez. Así lo reconoce Cicerón en un pasaje en el que se dice explícitamente:

Ideo melior videtur conditio causae bonae, si ad iudicem quam si ad arbitrum mittatur; quia illam formula includit et certos quos non excedat terminos possit huius libera et nullius adstricta vinculis religio (223). 
En idéntico sentido se expresa Cicerón en otro texto, cuando refiere el caso de Pisón, árbitro entre Roscio y Fannio, que concede más de lo pedido (ultra petita), al reconocer a Fannio un crédito de cien mil sextercios contra Roscio, en lugar de los cincuenta que se habían pedido (224).

3.3.2. El compromissum debe contener la fecha de la vista ante el árbitro. No era obligatorio establecer un día determinado, bastaba señalar un plazo dentro del cual se debe dictar sentencia:

T.H. 76 , p. 1, lín. 7 ss: ...(pal) lam coram utroque praesenti (sent)entiam prove sententia(m) dicat (dici)ve i(u)beat et (ante) idum ante $\mathrm{K}$ (alendas) (Feb)ruarias primas sent(nt)iam...

No obstante, y como señala Pomponio explícitamente, la fijación de la fecha no era un requisito obligatorio para la validez del compromissum:

Sed si compromissum sine die confectum est, necesse est arbitro omnimodo dies statuere, partibus scilicet consentientibus, et ita causam disceptari; quod si hoc praetermiserit, omni tempore cogendus est sententiam dicere (225).

Tal como señala el texto anterior, era necesario para el árbitro, fijar un día de acuerdo con las partes; fecha que en algunos casos era posible prorrogar, tal como en el siguiente pasaje afirma Ulpiano, basándose en la doctrina de Labeón y de Pomponio:

Labeo ait, si arbiter, cum in compromisso cautum esset, ut eadem die de omnibus sententiam diceret, et ut posset diem proferre, de quibusdam rebus dicta sententia, de quibusdam non dicta, diem protulit: valere prolationem sententiaeque eius posse impune non pareri. Et Pomponius probat Labeonis sententiam, quod et mihi videtur: quia officio in sententia functus non est. 1.- Haec autem clausula "diem compromissi proferre" nullam aliam dat arbitro facultatem quam diem prorogandi: et ideo condicionem primi compromissi neque minuere neque immutare potest: et ideo cetera quoque discutere et pro omnibus unam sententiam ferre debebit (226).

Paulo en sus Comentarios al Edicto afirma que la autorización para prorrogar el plazo debía ser incluida en el compromiso:

Arbiter nihil extra compromissum facere potest, et ideo necessarium est, adiici de die compromissi proferenda; ceterum impune iubenti non parebitur (227).

Cuando el árbitro lo creyera necesario, con el fin de evitar que se incurriera en la poema compromissi, podía prorrogar el plazo sin necesidad de acuerdo entre las partes. Paulo, en el libro XIII ad Edictum lo afirma expresamente:

Dies compromissi proferri potest, non cum ex conventione, sed cum iussu arbitri eam proferri necesse est, ne poena committatur (228). 
Pero no podía, en ningún caso, anticiparlo con la oposición de las partes. Papiniano, en el libro I Quaestionum, lo afirma expresamente:

Arbiter ita sumptus ex compromisso, ut et diem proferre possit, hoc quidem facere potest: referre autem contradicentibus litigatoribus non potest (229).

Ulpiano manifiesta que esta prórroga no tiene efecto alguno sobre el resto del contenido del compromissum, de manera que si era un compromiso sobre varios conflictos y tenía que dictar una sentencia sobre todos, no era válida la emitida sobre alguno de ellos con anterioridad a la prórroga del plazo para dictar la sentencia sobre el resto (230).

3.3.3. Por último, en el compromiso debía hacerse constar el lugar donde se iba a celebrar el juicio; había que distinguir una determinación general del lugar, en el sentido de fijar la ciudad o provincia, supuesto en el que la voluntad de las partes era lo más importante, del sitio preciso concreto en que el árbitro dictaría sentencia. A propósito de la determinación general, dice Ulpiano:

Si arbiter iussit, puta in provincia adesse litigatores, cum Romae esset in eum compromissum, an ei impune non pareatur, quaeritur. Et est verius, quod Iulianus ait libro quarto, eum locum compromisso inesse, de quo actum sit, ut promitteretur: impune igitur ei non parebitur, si alio loci adesse iusserit. Quid ergo, si non appareat, de quo loco actum sit? melius dicetur, eum locum contineri, ubi compromissum est. Quid tamen, si in eo loco, qui sit circa urbem, adesse iusserit? Pegasus admittit, valere iussum. Quod puto ita verum esse, si et eius sit auctoritatis arbiter, ut in secessibus soleat agere, et litigatores facile eo loci venire possint (231).

En cuanto a la concreción precisa del lugar en que iba a dictarse la sentencia, el propio Ulpiano hace las consideraciones siguientes:

Quod puto ita verum esse, si et eius sit auctoritatis arbiter, ut in secessibus soleat agere, et litigatores facile eo loci venire possint. Sed si in aliquem locum inhonestum adesse iusserit, puta in popinam vel in lupanarium, ut Vivianus ait, sine dubio impune ei non parebitur... et is non venerit, qui sine sua turpitudine eo venire possit, is venerit, qui inhoneste venerat, an committatur poena compromissi, an quasi opera non praebita? Et recte putat non committi: absurdum enim esse iussum in alterius persona ratum esse, in alterius non (232).

Mientras que en el proceso ordinario existía siempre un lugar en que debía celebrarse el juicio, en el caso de la actuación del árbitro no parece que la existencia de un lugar determinado fuera una condición previa para la celebración del compromissum.

Teniendo en cuenta las condiciones en que el árbitro podía pronunciarse, se hacen patentes los límites de su poder de decisión. Son las partes las que, de común acuerdo, deciden las cuestiones sobre las que él debe pronunciarse. Esto implicaba, por otro lado, la necesidad de que esas partes determinaran de forma precisa las 
cuestiones que eran objeto de discusión, ya que en otro caso el compromissum sería declarado nulo.

Y supuesto que el arbiter sólo podía juzgar sobre aquellos asuntos o controversias que existían en el momento en que las partes decidían someterse al dictamen arbitral, es indudable el paralelismo existente con el procedimiento ordinario; en él, en efecto, el juez estaba sometido a la fórmula y no podía manifestarse sobre otro tema que no estuviera recogido en ese documento, en que quedaban plasmados los términos del litigio.

A modo de ilustración de la forma de proceder del arbiter, entiendo que es útil hacer una referencia explícita al textum de un compromissum de comienzos del s. VI. En él se hace patente que se trataba de un desacuerdo a propósito de la cantidad de dinero que debía entregarse. Se procede indicando previamente los nombres de quienes litigaban (línea 1-10); inmediatamente después se alude al supuesto concreto que se planteaba (línea 10-12); posteriormente, la voluntad de las partes de acudir al árbitro queda manifestada de una forma expresa (línea 12-15); esto supuesto, se hace referencia al juramento (línea 16-17), insistiendo igualmente en el compromiso que asumen las partes de someterse a la sentencia arbitral (línea 18-19). Finalmente, tras aludir a la sanción prevista para el caso en que la decisión del árbitro fuera transgredida (línea 20-21), se contiene la ratificación.

El texto completo a que se hace referencia es el siguiente:

\section{COMPROMISSUM}

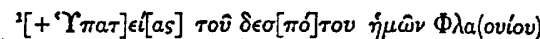

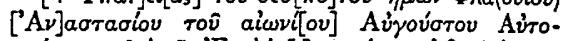

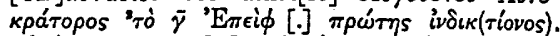

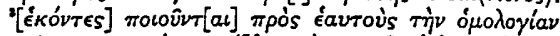

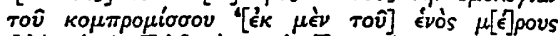

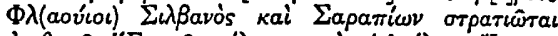

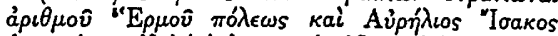

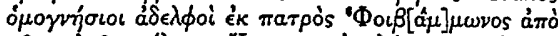

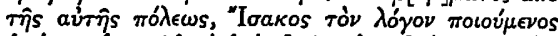

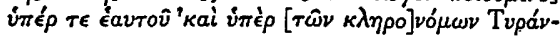

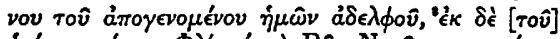

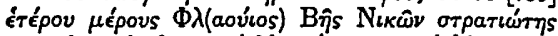

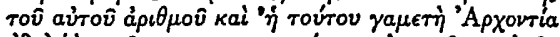

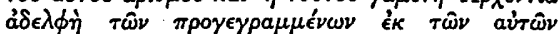

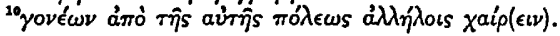

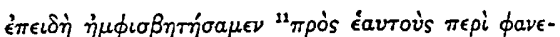

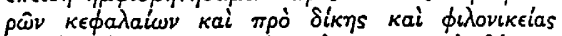

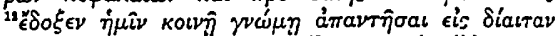

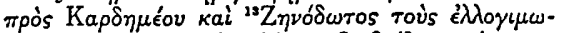

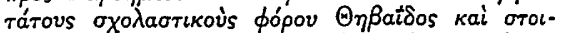

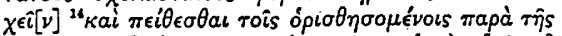

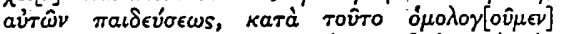

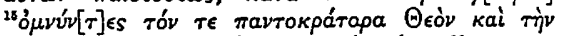

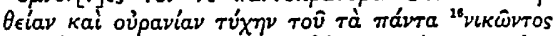

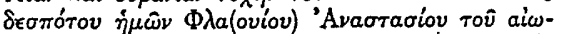

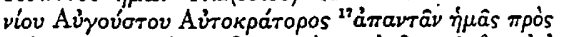

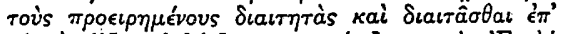

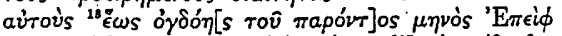

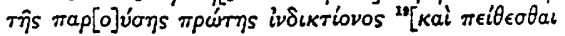

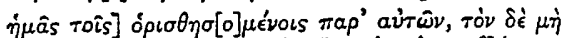

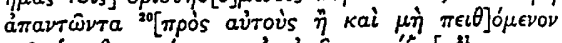

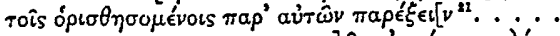

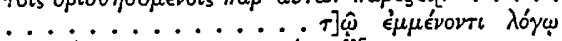

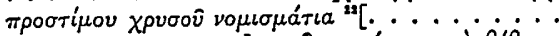

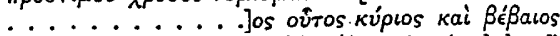

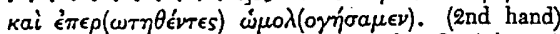

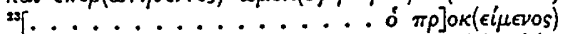

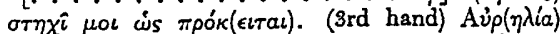

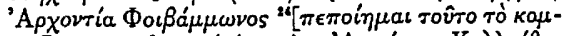

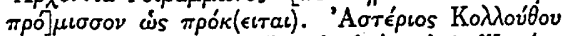

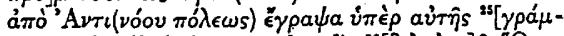

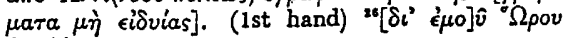

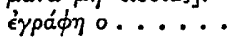

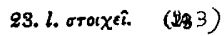




\section{PERSONAS QUE PUEDEN HACER UN COMPROMISO}

\subsection{La incapacidad de obrar y el compromissum}

En Derecho romano la capacidad de obligarse era indispensable para poder hacer un compromiso. Además, para que este compromiso tuviera valor y fuera reconocido por el pretor, debía estar garantizado por una stipulatio poenae. Esto supuesto, era lógico que quedaran excluidos, ante todo, los mudos, los sordos y los ausentes (234). Por otra parte, no tenían tampoco capacidad de obrar determinadas personas, en cuanto eran incapaces de realizar actos voluntarios a los que el ordenamiento jurídico atribuía el efecto de constituir, modificar o extinguir relaciones jurídicas, como el loco, el pupilo, la mujer, el filiusfamilias, el esclavo y el menor de veinticinco años.

\subsubsection{Furiosus}

Las XII Tablas ya hacen alusión a la falta absoluta de obrar de éste y añaden que precisa un custos que cuide de su persona y administre sus bienes (235).

Sin embargo, no hay en Derecho romano una noción única de demente; se distinguía entre furiosus y mentecaptus o demens. El criterio distintivo era que mientras que el furioso tiene intervalos de lucidez, el mentecato no. Para otros, sin embargo, la diferencia estriba en el hecho de que los furiosos son locos agitados y los otros son disminuidos mentales.

Los juristas romanos clásicos discutían si durante los momentos lúcidos el furiosus podía realizar válidamente actos jurídicos. Justiniano optó porque la cura fuera suspendida durante los momentos de lucidez, comenzando ipso iure apenas volviera a manifestarse la locura. En Roma, a diferencia de nuestro sistema actual, la incapacidad del loco surge sin necesidad de la intervención expresa de la autoridad en cuanto se manifiesta la enfermedad.

El curator no asiste al loco sino que le reemplaza en su voluntad ausente. La capacidad jurídica del loco para comprometerse estaría regida por el principio de todos los actos jurídicos, es decir, podría comprometerse en los momentos de lucidez y no podría hacerlo en los momentos de demencia.

\subsubsection{Pródigo}

Este instituto, recogido también en las XII Tablas (236), aparece con diferencias respecto de la figura anterior. Éstos, en efecto, precisan declaración expresa del magistrado mediante decretum para impedirles el ejercicio y administración de sus bienes. Esta declaración de incapacidad se llevará a cabo apenas manifestada, por necesidades prácticas del tráfico mercantil.

Antiguamente la prohibición para realizar negocios sería decidida por los mismos agnados y gentiles, correspondiéndoles a estos mismos el ejercicio de la cura, cura legítima que pondría directamente bajo su custodia al pródigo, sin necesidad de la intervención del pretor.

De los textos de los juristas clásicos se extrae la concepción de pródigo en el 
derecho de esta época; lo consideran como aquél que tiene tendencia a realizar gastos innecesarios dilapidando el propio patrimonio con perjuicio de sus herederos. $\mathrm{Al}$ no existir criterios absolutos que determinen cuándo un individuo realiza actos de prodigalidad sobre su patrimonio, correspondería al magistrado su valoración; por ello se le atribuyó al pretor la facultad de castigar mediante decreto de interdicción por prodigalidad, tanto al heredero testamentario como al esclavo manumitido que no puede tener ni agnados ni gentiles y nombrar al mismo tiempo un curator.

El decreto de interdicción era también el medio utilizado contra aquéllos que debían venir sometidos a curatela legítima.

Posteriormente se admitió la posibilidad de que fuera el paterfamilias el que designase al pródigo un curador que después sería nombrado por el pretor, previo decreto de interdicción.

El pródigo, al no ser considerado totalmente incapaz, podía realizar todo tipo de actos que supusieran mejora en su patrimonio, pero no aquéllos que empeoraran su situación económica. De esto se deriva que no tendría capacidad para obligarse; sin embargo, es opinión generalizada su admisión si los realizaba con el consensus de su curator.

Aquellos que asimilan al pródigo con el loco consideran que el consentimiento del curador no puede habilitar al pródigo para realizar actos que le perjudiquen en su patrimonio.

Si aceptamos la opinión dominante, debemos entender que el pródigo está capacitado para comprometerse, más si nos inclinamos por la contraria, es imposible admitir dicha capacidad. Todo ello es válido para el derecho clásico; en cambio, no podemos decir lo mismo en el Bajo Imperio, en el cual los textos recogen ya la posibilidad de que el pródigo se comprometa con la asistencia de su curator.

\subsubsection{Mujeres sometidas a tutela}

A diferencia de los hombres sui iuris que al alcanzar la pubertad si habían estado sometidos a tutela dejaban de estarlo, las mujeres sui iuris, incluso después de llegar a la pubertad, seguían sometidas a ella (237).

Esta tutela, que respondía a exigencias jurídicas y sociales vigentes todavía en época clásica, mereció la atención del jurista Gayo, que no encontraba justificación en lo que se refería a las mujeres púberes: Feminas vero perfetae aetatis in tutela esse (238).

El principio de que para la eficacia de los negocios jurídicos, realizados por mujeres púberes, fuera necesaria la interposición de la auctoritas del tutor, era aplicado sólo a los antiguos negocios iuris civilis; para los negocios surgidos o introducidos posteriormente y clasificados iuris praetorii y iuris gentium, bastaba la sola voluntad de la mujer. Gayo podía afirmar con razón que, en la práctica, durante su tiempo, las mujeres púberes llevaban directamente sus negocios (mulieres enim quae perfectae actatis sunt, ipsae sibi negotia tractant) (239).

La mujer, según el Senatus Consultum Velleianum (240) no podía compro- 
meterse por otro sin la autorización de su tutor. El Senatus Consultum establece absolutamente la prohibición para todas las obligaciones, tanto si hubieran salido fiadores de palabra, o con cosa, o con cualquier otro contrato.

\subsubsection{Pupilos}

Si el pupilo no puede realizar actos que empeoren su condición económica sin la auctoritas del tutor, tampoco podrá obligarse mediante compromiso, debido a que si bien la estipulación resultaría válida no podemos decir lo mismo respecto a la promesa de pena, que sería inválida.

El compromiso no sería plenum y el pretor no podría obligar al árbitro a dictar una sentencia que podía ser violada impunemente por el pupilo. A esto se refiere Gayo en los Comentarios al Edicto Provincial cuando afirma que, si un pupilo hubiera contraído compromiso, no se obligue al árbitro a dictar sentencia ya que si se pronunciara contra él no venía obligado por la pena:

Si pupillus sine tutoris auctoritate compromiserit, non est arbiter cogendus, pronuntiare, quia, si contra eum pronuntietur, poena non tenetur, praeterquam si fideiussorem dederit, a quo poena peti possit; idque et Iulianus sentit (241).

Del texto se deriva que se trata únicamente de una obligación natural contraída por el menor que sirve de base a un fideiussio, ya que el pupilo no se obliga por derecho civil sin la autoridad del tutor (242). Esta obligación natural no tiene otro objeto que vivificar las obligaciones de las personas que han garantizado el compromiso del pupilo. El derecho romano jamás elaboró una teoría general de las obligaciones naturales. Únicamente es posible entresacar como nota común a todas ellas la irrepetibilidad de lo pagado voluntariamente (243). Las obligaciones asumidas por el menor en Roma no producían los mismos efectos que actualmente estamos acostumbrados a unir a las obligaciones naturales. Esta obligación de ningún modo es peligrosa para el pupilo, ya que no tiene más efecto que hacer válido el pago de la pena, siempre que este pago fuera autorizado por el tutor.

El fideiussor que se encuentra obligado contractualmente puede solicitar una in integrum restitutio, aunque está obligado a saber que el pupilo es incapaz para obligarse civilmente y que será él quien quede obligado sin posibilidad de recurso contra el impúber. Con la autoridad del tutor el pupilo podrá contratar válidamente. Pero cuando fue creada la in integrum restitutio en favor de los menores de veinticinco años los juristas, interpretando el derecho pretorio, entendieron que los actos hechos por los pupilos únicamente fueran válidos cuando se hicieran con la auctoritas tutoris, por lo que consideraban que el compromiso hecho por un impúber siempre podría resultar peligroso. Por ello, no podrá ser obligado el árbitro a dictar sentencia si el pupilo se comprometió sin la autoridad del tutor. Tampoco estará el pupilo obligado a pagar la pena si ésta fuera contraria a él, excepto si hubiera dado un fiador de quien pueda reclamarse la pena.

Del mismo modo se pronuncia Juliano al afirmar: Si compromissum ita factum sit, ut praesente utroque aut heredibus eorum arbiter sententiam dicat, et 
alter ex litigatoribus decesserit pupillo herede relicto, non aliter videtur sententia dicta esse, nisi tutoris auctoritas interposita fuerit (244).

\subsubsection{Esclavos}

El esclavo no puede estipular ni prometer en su nombre; sólo puede hacerlo en nombre del dominus, por lo que jamás un esclavo podrá realizar un compromissum plenum. Así opina Paulo cuando dice: Servus autem ex contractibus non obligatur (245).

En el caso de que un esclavo se hubiera comprometido, el árbitro no será compelido a dictar sentencia ni el dominus responderá por él con la actio de peculio. En caso de que el árbitro llegara a dictar sentencia no se dará ejecución, ya que el compromiso no existe legalmente:

Si servus compromiserit, non cogendum dicere sententiam arbitrum, nec, dixerit, poenae executionem dandam de peculio putat Octavenus (246).

Los juristas aproximan el compromiso al juicio cuando consideran que, de la misma manera que un esclavo no puede ser obligado por un juicio, tampoco lo sea por un compromiso. La opinión quizá no es convincente, pero si que muestra la tendencia a aproximar el compromiso a un juicio y a separarlo de los contratos.

Por ello consideran que si un esclavo, conduciéndose como libre, hubiera contraído un compromiso, no se debe conceder la acción de peculio, ya que ni siquiera se daría si el esclavo hubiera sido condenado en un juicio:

Si servus, quum se pro libero gereret, compromiserit, quaeritur, an de peculio actio ex poena compromissi, quasi ex negotio gesto. Sed hoc et Nerva filio, et mihi videtur verius, ex compromisso servi non dandam de peculio actionem, quia nec si iudicio condemnetur servus, datur in eum actio (247).

El compromiso devenía nulo, tanto para el esclavo como para aquella persona libre que se hubiera comprometido con él, no estando por tanto obligados a pagar la pena.

Es lógico pensar que serían motivos de equidad lo que llevó a los juristas a manifestarse en este sentido, pues en rigor de los principios, quien estuviera obligado con el esclavo tendría que estarlo respecto al dueño.

Se ha pretendido a veces ver el fin del compromiso como la petición del montante de la pena en el caso de que la sentencia fuera violada. Sin embargo, a través de los textos analizados, hemos podido comprobar que esta interpretación resulta extraña al Derecho romano.

En la concepción romana, el fin del compromiso es la ejecución de la sentencia y la pena no es más que una sanción que suple a la fuerza legal que el árbitro no puede dar a su decisión. Se trata sin duda de una semejanza con los juicios que tienen por finalidad terminar con las controversias. 
En este sentido se manifiesta Pablo cuando afirma: Compromissum ad similitudinem iudiciorum redigitur, et ad finiendas lites pertinent (248).

\subsubsection{Filiusfamilias}

Los hijos de familia están en la misma situación que los pupilos de modo que son capaces de comprometerse y por tanto se puede dar la actio de peculio contra el padre. Pero aún hay más; si el hijo se comprometiera por negocios extraños al peculio, el padre queda obligado ex stipulato hasta el límite del peculio. De modo que el padre también vendrá obligado por un compromiso independientemente de la causa por la cual se hubiera contraído dicho compromiso.

En este sentido se manifiesta Papiniano: ... nec interesse ait, ex qua causa compromiserit, utrum ex ea causa, ex qua potuit cum patre de peculio agere, an vero ex ea, qua non potuit, quum ex stipulatu pater conveniatur (249).

El compromiso que viene siempre acompañado de una estipulación como contrato verbis obliga al hijo in solidum y al padre en los límites del peculio, aunque, como hemos dicho anteriormente, el contrato fuera extraño a la administración de éste.

\subsubsection{Administradores}

En un principio, de los actos realizados por el tutor sólo nacían acciones ejercitables por él o contra él, de lo que se deduce que si el tutor contraía un compromiso sería el único a quien le correspondería la actio poenae; sin embargo, a partir del siglo II se concedieron acciones útiles tanto al pupilo como al tercero que hubiera realizado negocios con el tutor. La actio iudicati le correspondía directamente al impúber (250); pero ¿qué ocurre respecto al compromiso? ¿cabe por analogía decidir que también le concierne la actio poenae resultante del compromiso? Los textos no comentan nada en este sentido ni tampoco las fuentes recogen nada que nos permita creer que los juristas lo hayan admitido alguna vez.

Otra pregunta que nos surge es: ¿está el tutor autorizado a comprometerse por el pupilo? o ¿hay que aplicar aquí la regla que impide a los tutores realizar aquellos actos que supongan disminución en el patrimonio del pupilo? (251). Somos partidarios de aceptar la posibilidad de comprometerse el tutor, en cuanto no tiene por qué suponer necesariamente una disminución patrimonial dicho compromiso.

Sin embargo, en virtud de este principio, creemos que el tutor, que sólo podría actuar en aquellos actos que supusiesen ventaja para el pupilo, no podría comprometerse sobre los praedia rustica y suburbana después de la constitución otorgada por Septimio Severo. Todos los actos realizados por el tutor quedan sometidos al riesgo de la in integrum restitutio.

Lo mismo podemos decir respecto a los curadores y al marido que no pueden vender los fundos dotales y que, por tanto, no podrían comprometerse sobre estos fundos. 


\subsubsection{Bonorum cedens}

Esta figura plantea un interrogante: el deudor que llega a una situación de insolvencia involuntaria y cede sus bienes a fin de escapar a la ejecución personal ¿puede conprometerse? Podemos establecer cierta similitud con el iudicium en lo que se refiere a la capacidad del bonorum cedens; y vemos que al igual que ocurre en el proceso, en que no se puede demandar ni ser demandado, se podría aplicar para el compromiso. Así opina Juliano cuando escribe: Non esse cogendum arbitrum sententiam dicere, quum neque agere, neque convenire possit (252).

La obligación por parte del bonorum cedens carece de garantía desde el momento en que ha perdido el derecho a disponer de sus bienes, ya que su situación es la misma que la de aquél cuyos bienes han sido jurídicamente vendidos.

Otra cuestión a debatir es la admisión de representación en materia de compromiso; ies factible compromittere de re aliena? Por lo que se refiere a la representación directa, el derecho romano la desconoció, ya que las partes que concertaban un negocio jurídico estaban obligadas a intervenir personalmente en él, de manera que sólo produce efectos jurídicos entre las partes que lo realizaron. Regla que fue observada también, en principio, en los procesos.

Este principio de representación en el período de las legis actiones era inconcebible debido a la obligación de las partes de comparecer personalmente tanto en la etapa in iure, ante el magistrado, como en la etapa apud iudicem, ante el juez, aunque se recogen ciertas excepciones de las que nos informa Justiniano: Nunc admonendi sumus, agere posse quemlibet hominem aut suo nomine, aut alieno: alieno veluti procuratorio, tutorio, curatorio, quum olim in usu fuisset, alterius nomine agere non posse, nisi, pro tutela, pro libertate, pro populo (253).

Estas excepciones vienen dadas por su propia naturaleza; en relación con la primera, ya hemos visto anteriormente que era el tutor el que actuaba en nombre del pupilo. Pro libertate ya que se trata de vindicar un esclavo su libertad y, al no ser capaz, precisa alguien que actúe por él (adsertor libertatis) y pro populo ya que al ejercer una acción popular se supone está litigando en nombre del pueblo.

Aparte de estas excepciones la lex Hostilia (254) recoge otros tantos casos que permiten la representación excepcionalmente:

...praeter ea lege hostilia permissum erat furti agere eorum nomine, qui apud hostes essent, aut reipublicae causa abesent, quive in eorum cuius tutela essent... coeperunt homines per procuratores litigare; nam et morbus, et actas, et necessaria peregrinatio, itemque aliae multae causae saepe hominibus impedimento sunt, quo minus rem suam ipsi exequi possint.

La ley trata de dar solución a aquellos casos en los que hallándose ausente una persona por causa pública, alguien pudiera hacerse cargo del litigio si había sido dañado en sus bienes.

Abundando más en ella vemos que también admitió la figura del procurador en el procedimiento de las legis actiones, en aquellos litigios en los que fuera parte una 
persona que se viera incapacitada para acudir a ellos, bien por motivos de enfermedad o por avanzada edad.

Todo esto sufrió una evolución en el proceso firmulario; no ya como medida excepcional, sino cuando conviniese a algunas de las partes, podrían hacerse representar por medio de procurador.

Sería en el cognitor en quien recaería la sentencia, tanto fuera favorable o no, debido a que en principio no se admitió la representación directa y, por tanto, también sería a él a quien se concedería la actio iudicati para solicitar la ejecución de la sentencia.

Paulatinamente se fueron creando fórmulas que evitaran los inconvenientes propios de este tipo de representación, de manera que al actuar el procurador en nombre del demandante se considerase como si fuera él mismo (255).

Se admitió la posibilidad de conceder la actio iudicati al demandante que habiéndole sido favorable la sentencia pudiera ejercerla sobre el demandado, obteniendo por si mismo los resultados de la sentencia (256).

Distinto sería cuando el cognitor hubiera sido nombrado por el demandado, pues en este caso se le exigiría una garantía que cubriese el riesgo de insolvencia del representante.

También debemos insistir en que la evolución se produjo en el mismo mandato recibido por el procurator, pues mientras que en un principio actuaba por mandato expreso y solemne de las partes, poterirmente lo hacía tan sólo en virtud de un mandato genuino anterior a la litis contestatio y ni siquiera se precisa el conocimiento ni la presencia de la otra parte litigante.

Este modo de actuar creaba cierta inseguridad en la parte contraria, que no podía saber si actuaba en nombre propio o en el del litigante y además desde el momento que la acción no era consumida, el dominus negotii podía, si la sentencia obtenida por el procurator no les satisfacía, reproducir él mismo la acción. Para evitar estos inconvenientes se exigió al procurador una garantía por la que respondía de que el dominus negotii acatara el resultado del litigio, cualquiera que fuera. Ésta es la llamada cautio de rato o cautio ratam rem dominus habiturum.

La pregunta que nos surge después de estas consideraciones es de si puede aplicarse o no al compromiso: ¿cabe la actuación de un procurator por alguna de las partes compromisarias?

Somos partidarios de aceptar la representación en el compromiso debido a que en el arbitraje no se producen los mismos efectos que produce el proceso y no porque no se consumiese la acción al actuar el procurator, sino porque la sentencia emitida por el árbitro no produce los efectos de cosa juzgada propios de una decisión judicial.

Además existe la posibilidad de que pueda deducirse en un proceso posteriormente, si la sentencia no es del agrado de una de las partes. Independiente todo ello de que aqui no cabe el ejercicio de la actio iudicati por parte de aquél a quien ha favorecido la sentencia, pues, como ya hemos dicho anteriormente, el efecto mismo 
del compromiso es del pago de la pena por el incumplimiento de la sentencia y no cabe el perseguir su ejecución. Por todo ello consideramos que ofrece menos dificultades la representación en un arbitraje.

No parece tampoco necesaria la ratificación por parte del litigante a quien representa, debido a que si se diera la hipótesis de que el dominus no respetara la sentencia del árbitro, la falta de ratihabitio conllevaría la stipulatio committur.

\section{OBLIGACIONES DE LAS PARTES}

\subsection{Obligaciones de las partes antes de la sentencia}

Es posible distinguir dos clases de obligaciones en el compromiso concluido por las partes. Unas son las que pesan sobre los litigantes hasta el momento en que el árbitro pronuncia la sentencia e impiden que puedan hacer cualquier cosa que obstaculice el curso de la sentencia del árbitro. Otras son las que nacen en el momento en que la sentencia se dicta, debiendo someterse a ella las partes, sea cual fuere el resultado. La sanción es la misma para estas dos clases de obligaciones y el litigante que las viola incurre en la pena prevista.

Hasta el momento en que el árbitro dicte la sentencia, sus decisiones deben ser obedecidas por las partes, siempre que se mantenga dentro de los términos fijados por el compromiso. Puede convocar a los litigantes cuando lo considere necesario, aunque éstos no incurran en pena más que en el caso de que su resistencia o desobediencia impida que la sentencia sea pronunciada. Si la negligencia de las partes no dificulta el término del compromiso, no serán castigadas, por lo que no se verá afectada más que la parte que fuera considerada culpable. No se incurre en la pena del compromiso más que en aquellos casos concretos en que el árbitro hubiera ordenado pagar dinero o prestar una determinada actividad. En los demás casos, la partes pueden negarse a obedecer, o a declarar los nombres de los testigos reclamados en virtud de una decisión arbitral:

Non ex omnibus causis, ex quibus arbitri paritum sententiae non est, poena ex compromisso committitur, sed ex his duntaxat, quae ad solutionem pecuniae, aut operan praebendam pertinent. Item contumaciam litigatoris arbiter punire poterit pecuniam eum adversario dare iubendo; quo in numero haberi non oportet, si testium nomina ex sententia arbitri exhibita non sunt (257).

A propósito del caso en que la rebeldía de una de las partes litigantes impidiera al árbitro dictar sentencia, esa actitud sería considerada como un hecho grave, de acuerdo con lo que dice Paulo en el Libro XIII ad Edictum (258). Cuando las partes no están presentes en el momento en que se pronuncia la sentencia, ésta será considerada inválida, a menos que las partes se hayan manifestado de forma expresa en sentido contrario.

Por otra parte puede considerarse fundada la opinión de Declareuil que piensa que la misma solución debe darse para el caso en que las partes se hubieran hecho representar por procuratores, cuando el árbitro les hubiera ordenado estar presentes 
en persona. Al contrario, según el mismo autor, si la misma convocatoria hubiera sido dirigida al heredero mencionado en el compromiso, su desobedencia al iussum arbitri no impediría el dictar sentencia (259).

Si una de las partes estaba sometida a tutela, el tutor debía estar presente (260). En caso de locura, la sentencia sólo podía ser pronunciada estando presente el curator, de modo que si esto no ocurría, el arbiter debía abstenerse (261).

En cuanto a la forma de convocar a las partes, no existía una concreta determinada, sino que podía hacerse a través de un medio cualquiera (vel per nuntium, vel per epistolam) (262). Pero para que se incurriera en la pena era necesario que la ausencia de la parte fuera la causa principal de la imposibilidad de la sentencia. Pomponio plantea el supuesto siguiente: un árbitro ordenó que se compareciera en las Kalendas de enero, pero falleció antes de ese día, no compareciendo uno de los litigantes. Según el jurista no cabe duda de que en manera alguna se incurrió en la pena, ya que tratándose de aquel árbitro que él mismo no se hubiera presentado, no se incurre en la pena, de acuerdo con la doctrina sentada por Aristón y Casio:

Arbiter Kalendis Ianuariis adesse iussit, et ante eum diem decessit, alter ex litigatoribus non adfuit; procul dubio poena minime commissa est. Nam et Cassium audisse se dicentem Aristo ait, in eo arbitro, qui ipse non venisset, non esse commissam; quemadmodum Servius ait, si per stipulatorem stet, quo minus accipiat, non comitti poenam (263).

Idéntica solución debería darse si el árbitro dejara pasar el término fijado por el compromiso, ya que, en este caso, su misión habría terminado y no tendría ya el derecho ni de convocar a las partes ni de pronunciar la sentencia (264). En el caso de que un litigante hubiera impedido llevar a término el compromiso, es evidente que no podría valerse contra el otro aduciendo el defecto de ese compromissum (265).

Pero como afirma Declareuil (266), aparte de estas circunstancias particulares en que la contumacia de un litigante quedaba cubierta ya sea por un caso fortuito o por una falta del árbitro o de la otra parte, había otros casos en los que el pretor admitió la existencia de excusas legítimas. En los textos del Digesto se encuentran ejemplos muy ilustrativos de ello:

Si quis ex litigatoribus ideo non adfuerit, quod valetudine, vel Reipublicae causa absentia impeditus sit, aut Magistratu, aut alia iusta de causa, poenam committi Proculus et Atilicinus aiunt; sed si paratus sit in eundem compromittere, actionem denegari, aut exceptione tutum fore. Sed hoc ita demum verum erit, si arbiter recipere in se arbitrium fuerit paratus; nam invitum non esse cogendum Iulianus libro quarto Digestorum recte scribit; ipse autem nihilo minus poena absolvitur (266).

Este texto pone de manifiesto cómo fue atenuándose con el tiempo el rigor con que se aplicaba el derecho originariamente. En efecto, desde el momento de que la falta de sentencia era resultado de un hecho de una de las partes, se incurría en la pena. La estipulación era strictis iuris, de modo que no importaba que la ausencia 
estuviera motivada por la salud de quien no se presentaba, o por cualquiera de las razones a que se alude en el texto.

Después de un proceso de evolución, se terminó por decidir que no podía incurrirse en la pena más que por la ausencia del deudor. Ulpiano, apoyándose en pasajes de Celso dice textualmente:

Idem ait, si iusserit me tibi dare, et valetudine sis impeditus, quo minus accipias, aut alia iusta ex causa, Proculum existimare, poenam non committi, nec si post Kalendas te parato accipere non dem. Sed ipse recte putat duo esse arbitri praecepta, unum pecuniam dari, aliud intra Kalendas dari, licet igitur in poenam non committas, quod intra kalendas non dederis, quoniam per te non stetit, tamen committis in eam partem, quod non das (267).

Teniendo en cuenta la evolución que tuvo lugar en esta materia, hay que destacar que, si al principio se incurría en la pena por el solo hecho de la no ejecución de la sentencia, sin que fuera necesario investigar si hubo o no falta, se trataba de una solución que tiene una explicación lógica. En efecto, Declareuil ha subrayado explícitamente lo siguiente: Cette solution se rattache à cette idée, déjà exprimée, que la faute résultant de la responsabilité de l'homme n'a pas été aperçue à l'origine. On l'a confondue avec le dommage involontairement causé (268).

Posteriormente, cuando la capacidad de análisis fue desarrollándose en la conciencia romana, esta asimilación fue considerada como algo chocante, comenzándose a usar el procedimiento a que hace referencia el texto del Digesto citado anteriormente (269) y aplicándose después el principio que aparece en los textos propios de la época clásica, a saber, que obedecer a la sentencia consiste en hacer lo que depende de uno mismo para ejecutar esa sentencia:

...nihil aliud esse sententiae stare posse, quam id agere, quantum in ipso sit, ut arbitri pareatur sententiae (270).

No se incurre en la pena más que cuando existe falta, $y$, por otra parte, debe subrayarse que las partes quedaron siempre libres de dejar los casos fortuitos a cargo del promissor y de mantener de este modo voluntariamente las consecuencias que se derivan del antiguo derecho.

Estas reglas no se aplican sólo a la contumacia o a la falta de una de las partes, sino también a todos los actos por los que pueden impedir o retrasar la sentencia. Puede acontecer que ésta no se diera a causa de maniobras dolosas de una de las partes. En este caso se incurre siempre en pena, tal como subraya explícitamente Ulpiano:

Et si quis praesens arbitrum sententiam dicere prohibuit, poena committetur (271).

Lo mismo ocurre cuando, a pesar del compromissum, uno de los litigantes decide recurrir a la jurisdicción ordinaria. El compromiso no ha extinguido la antigua acción y nada puede oponerse a que la causa siga su curso delante de los tribunales, que no pueden negarse a juzgar. Algunos jurisconsultos consideraban esta 
solución tan evidente que no veían en ella más que un hecho completamente natural que extinguía el compromiso y hacía imposible incurrir en pena. Pero esto era un error evidente, ya que, según observa Ulpiano, con su sistema una de las partes hubiera podido violar a su antojo un pacto garantizado por una stipulatio poenae. En realidad, la sentencia se ha hecho imposible porque la pena ya se ha cometido. El pretor no forzará ya al árbitro a pronunciarse pero concederá la fórmula de la actio poenae contra la parte culpable, tal como se lee en un pasaje importante de Paulo en sus Comentarios al Edicto:

Si quis rem, de qua compromissum sit, in iudicium deducat, quidam dicunt, Praetorem non intervemire ad cogendum arbitrum sententiam dicere, quia iam poena non potest esse, atque si solutum est compromissum. Sed si hoc obtinuerit, futurum est, ut in potestate eius, quem poenitet compromisisse, sit compromissum eludere. Ergo adversus eum poena committenda est lite apud iudicem suo ordine peragenda (272).

A propósito de las últimas palabras de este pasaje (...lite apud iudicem suo ordine peragenda), se han planteado cuestiones de diverso orden que han inducido a algunos a considerar tales palabras como producto de una interpolación llevada a cabo por Triboniano, basándose en que en la época de éste todos los juicios eran extraordinarios y los asuntos se llevaban y se apelaban ante los magistrados siguiendo una jerarquía. Aunque esto fuera posible, el principio que se enuncia en el pasaje De iudiciis queda perfectamente establecido, no pudiéndose atribuir a Triboniano haber interpolado el texto de Marcelo en que se dice:

ubi acceptum est semel iudicium, ibi et finem accipere debet (273).

La consecuencia de este principio es que la parte que ejercita tal acción viola el compromiso, y por tanto, incurre en la pena. Esa acción sigue su curso, pudiendo triunfar o no, pero en ambos casos la parte deberá pagar la pena. La litis contestatio no tendrá ninguna influencia sobre la stipulatio poenae, ya que esta stipulatio no depende en absoluto de la obligación que va a ser objeto del proceso. Idéntico principio encontramos también formulado en el Codex Gregorianus, en una constitución de Diocleciano y de Maximino, cuando se afirma que, quien contrariamente al compromiso, intente la acción del contrato, incurrirá en pena, pero no puede oponérsele una exceptio (274).

En un primer momento esto parece oponerse a lo que afirma Ulpiano cuando dice que si después de abandonar el arbitraje las partes acuden ante el juez y después deciden volver de nuevo al árbitro, pueden hacerlo. La cuestión que se plantea es: ¿cómo puede hacerse esto si todo juicio comenzado debe necesariamente seguir su curso? La contradicción entre ambos textos es sólo aparente, porque se puede uno comprometer sobre un litigio pendiente ante un juez, ya que hasta la litis contestatio las partes son libres para acudir, si lo desean, ante un árbitro que dirima la controversia existente entre ellas. En la época clásica se impuso una nueva regla según la cual omnia iudicia absolutoria sunt (275) en virtud de la cual el juez podía absolver al que debiera ser condenado, si antes de ser juzgada la cuestión 
satisfacía al actor, a pesar de que cuando se hizo cargo de la demanda se encontraba en la situación de que debiera ser condenado.

\subsection{Obligaciones de las partes después de la sentencia}

Una vez pronunciada la sentencia las partes tienen el deber de ejecutarla y obedecerla, ya sea justa o injusta, ya que a eso precisamente se han comprometido. Ulpiano afirma explícitamente:

Stari debet autem sententiae arbitri, quam de re dixerit, sive aequa, sive iniqua sit; et sibi imputet, qui compromisit. Nam et Divi Pii Rescripto adiciitur: "vel minus probabilem sententiam aequo animo ferre debet" (276).

La sentencia dictada puede absolver al reus. En ese caso, si el petitor intenta contra él una acción, el reus no podrá oponerle una exceptio sino que incurrirá en la pena, pudiendo intentar una actio poenae. Por el contrario, si el demandado es condenado, el demandante puede perseguir la pena ante la negativa del demandado a ejecutar la sentencia.

Existen dos stipulationes poenae. Cada una de las partes puede incurrir en la pena si se niega a que la sentencia sea ejecutada. La pregunta que se plantea es a propósito del significado que deba darse a la obediencia a la sentencia. Anteriormente hemos señalado que obedecer la sentencia consiste en ejecutar materialmente la orden dada por el árbitro. Así era originalmente, pero la práctica y un análisis más exacto de los hechos jurídicos impusieron la idea de que obedecer a la sentencia era hacer lo que dependía de uno para ejecutarla y que, esto supuesto, no se incurría en la pena estipulada (277). Para incurrir en la pena es preciso haber cometido una falta que puede resultar de dos órdenes de hechos diferentes, a saber, el rechazo a ejecutar la sentencia o bien la negligencia total o parcial y, por otra parte, la mora.

La no ejecución total y dolosa entraña incurrir en pena, porque ésta es el único medio de obligar a ello. Se incurre en la pena sin que sea preciso investigar si la parte ganadora tiene interés o no en que la sentencia sea ejecutada. Modestino afirma a este propósito en el Liber VI Regularum lo siguiente:

Quum poena ex compromisso petitur, is qui commisit, damnandus est; nec interest, an adversarii eius interfuit, arbitri sententia stari, nec ne (278).

En caso de inejecución parcial se incurre en la pena por el todo, cuando la obligación que resulta de la sentencia es indivisible o cuando la voluntad de las partes es que se incurra en la pena in solidum. Tal era, al menos, la solución que prevalecía en la época clásica. Otra duda se plantea respecto a si la pena se acumula con el objeto de la obligación principal o reemplaza a éste. Los textos muestran que en estos casos se daba prevalencia a la voluntad de las partes y el silencio se presumía en favor de la no acumulación.

La teoría de la no acumulación y la que se refiere a la falta del deudor, exigida para que incurra en pena, se desarrollaron al mismo tiempo, siguiendo las mismas 
fases. En la época clásica se exigía siempre, para incurrir en pena, que existiera la falta por parte del deudor, según vimos anteriormente. Ahora bien, ello exige referirse explícitamente a las consecuencias que se derivan de este planteamiento. Ante todo no se incurrirá en pena cuando el deudor se vea imposibilitado para ejecutar la sentencia. Tal imposibilidad puede deberse a causas diversas, como puede ser el caso fortuito, o bien, extraño a las dos partes o de un hecho de una de las partes. En el primer caso es evidente que no existe pena ya que nadie está obligado a lo imposible. Si el hecho que motiva la imposibilidad es imputable al acreedor no se incurre en la pena ipso iure, de acuerdo con la afirmación que hace Celso cuando escribe:

...si arbiter me tibi certa die pecuniam dare iusserit, tu accipere noluisti, posse defendi, ipso iure poenam non committi (279).

En este texto se trata de un demandante que no ha querido recibir la suma que le ofrecía el demandado, de acuerdo con la sentencia del árbitro. Ahora bien, hubo inicialmente una cierta vacilación en la doctrina, tal como se refleja en las palabras posse defendi del texto citado. Otros textos admiten la concesión de una exceptio al deudor si la no ejecución tuvo lugar por el hecho del acreedor. Pero Ulpiano no admitiendo la exceptio y decidiendo que la demanda del acreedor será rechazada ipso iure, reproduce la doctrina que había definitivamente triunfado anteriormente.

Por otra parte no es necesario que exista dolo por parte del acreedor, basta su hecho, supuesto que no ha actuado en el ejercicio legítimo de un derecho. Paulo añade que si más tarde el acreedor se declara dispuesto a recibir deberá ser pagado, puesto que hasta ese momento la orden del árbitro no se ha ejecutado:

sed si postea ille paratus sit accipere, non impune me non daturum; non enim ante feceram (280).

Así pues, el hecho del acreedor, que impide que no se incurra en pena no libera al deudor y la deuda subsiste. La imposibilidad puede nacer en la persona del demandante. Antiguamente la pena era siempre debida y ésta era todavía la opinión de Labeón. Suponiendo que el deudor hubiera muerto, este jurista decide que la pena deberá ser pagada aunque el heredero se presentara ofreciéndose a ejecutar la sentencia. Para decidir así, Labeón se basa en una verdad evidente, a saber, que una vez muerto el deudor, existe la seguridad de que no pagará. Por tanto, se incurre en la pena incluso antes del tiempo en que podría existir la mora. Este tigor desaparece en tiempos de Ulpiano. El heredero representaba al difunto en todo y para todo y no se podían rechazar sus ofertas; como observa Declareuil, este nuevo derecho era tanto más racional que si le défendeur avait eu gain de cause et que, aprés sa mort son héritier eût intenté l'action primitive, il n'y avait pas l'ombre d'un doute que la peine eût été encourue par lui (281). Estando obligado el heredero a respetar la sentencia si no quiere incurrir en la pena, no es justo castigarle cuando cumple su deber. El testimonio de Ulpiano es explícito en este sentido:

Si heredis mentio vel ceterorum facta in compromisso non fuerit, morte solvetur compromissum; nec utimur Labeonis sententia, qui existimavit, si arbiter aliquem pecuniam dare iusserit, et is decesserit antequam daret, poenam committi, licet heres eius paratus sit oferre (282). 
Dijimos anteriormente que para incurrir en la pena era preciso haber cometido una falta y que ésta podía resultar no sólo del rechazo a ejecutar la sentencia, o de la negligencia al hacerlo, sino también de la mora.

En efecto, el árbitro puede haber indicado en la sentencia un plazo para ejecutarla, o bien no haberlo hecho. Si ha señalado ese plazo se incurre en la pena al vencimiento del mismo y una oferta tardía no puede salvar al deudor. Pero en el caso de que no haya fijado un plazo, ¿cuándo podrá decirse que el deudor está en mora? En primer lugar habrá que concederle un quoddam modicum tempus, después del cual el acreedor podrá dirigirle una interpellatio que le constituirá en mora y que no será irrevocable como en el primer caso. Esta mora no tendrá por efecto más que hacer que pase el pago de la pena a un primer plano, esto es, hacer de él la obligación principal. Pero el deudor conservará siempre in facultate solutionis hasta la litis contestatio. He aquí cómo se expresa Ulpiano:

Intra quantum autem temporis, nisi detur, quod arbiter iusserit, committatur stipulatio, videndum est. Et si quidem dies adiectus non sit, Celsus scribit libro secundo Digestorum, inesse quoddam modicum tempus, quod ubi praeterierit, poena statim peti potest; et tamen, inquit, etsi dederit ante acceptum iudicium, agi ex stipulatu non poterit (283).

Incluso en el primer caso, cuando la sentencia ha fijado un plazo y el deudor está en mora, puede ofrecer el pago. Si el acreedor acepta ya no podrá actuar ex stipulatu sin que se le aponga la exceptio doli mali. Sin embargo, esta facultad de exigir la pena o de aceptar las ofertas que le son hechas pertenece totalmente al acreedor, el cual actuará conforme a sus intereses. Un caso fortuito puede incluso hacer la oferta imposible. Cosa muy distinta ocurre cuando el deudor todavía no está en mora; el caso fortuito no le hace ya temer una reclamación de la poena compromissaria, porque basta que haya hecho lo que estaba en su poder para que la sentencia fuera ejecutada, según vimos anteriormente (284). En efecto, Celso presentaba el caso siguiente: Yo he sido condenado por un árbitro a pagarte una determinada suma y, a causa de una enfermedad, tú no has podido recibirla antes de las Kalendas de Marzo, época determinada por el árbitro. Próculo piensa que no se incurre en la pena, porque la no ejecución no ha dependido de mí. En cambio, Celso divide las órdenes del árbitro del modo siguiente: 1) pagar una suma de dinero; 2) pagarle antes de las Kalendas. Esta última obligación es la única que queda extinguida por el caso fortuito. La obligación de pagar subsiste siempre garantizada por la pena. He aquí las palabras textuales de Ulpiano en el libro XIII de los Comentarios al Edicto:

Idem ait, si iusserit me tibi dare, et valetudine sis impeditus, quo minus accripias, aut alia iusta ex causa, Proculum existimare, poenam non committi, nec si post Kalendas te parato accipere non dem. Sed ipse recte putat duo esse arbitri praecepta, unum pecuniam dari, aliud intra Kalendas dari, licet igitur in poenam non committas, quod intra Kalendas non dederis, quoniam per te non stetit, tamen committis in eam partem, quod non das (285). 
A fin de completar la doctrina expuesta sobre las obligaciones de las partes, hay que hacer también referencia a los herederos. En efecto, el compromissum no pasa ad heredem, a no ser que las partes hayan insertado en él una cláusula especial ut transeat ad heredem. Si es así, el compromiso vale contra el heredero, en cualquier momento que sobrevenga la muerte de su autor, mientras que si la cláusula no ha sido insertada el compromissum no pasa a los herederos. La muerte del compromisario extingue el pacto, y vemos que Labeón decide todavía que la muerte de uno de los que han contraído el compromiso lleva consigo el incurrir en la pena, aunque el heredero ofreciera cumplir la sentencia. Pero posteriormente parece que esta doctrina ha sido abandonada de acuerdo con la expresión usada por Ulpiano: nec utimur Labeonis sententia. De ahí se concluía que, una vez pronunciada la sentencia, las partes transmitían a sus herederos sus obligaciones y derechos:

Si heredis mentio vel ceterorum facta in compromisso non fuerit, morte solvetur compromissum; nec utimur Lebeonis sententia, qui existimavit, si arbiter aliquem pecuniam dare iusserit, et is decesserit antequam daret, poenam committi, licet heres eius paratus sit oferre (286).

En la gestión del negocio el dominus no está obligado más que cuando lo ha ratificado. Pero el gestor no tiene necesidad de ofrecerla cautio de rato, puesto que si la sentencia no se cumple ese gestor incurrirá en la pena. Y lo mismo acontece con el procurator.

Sería también desobedecer al árbitro si, lo que él ha prohibido al demandado se pidiera a su fideiussor, porque éste tiene un recurso contra el reus. No hay ninguna duda de que se incurrirá en la pena. Pero si el compromiso ha sido hecho con el fideiussor y éste, habiendo sido absuelto, se dirige al demandante no se incurre en la pena puesto que, en general, el fideiussor no tiene interés en que el demandado sea perseguido judicialmente. En caso de que tal interés existiera (por ejemplo, si el demandado fuera el procurator del fideiussor) habría que decidir que la pena es debida, puesto que el procurator, que tiene una acción para recurrir contra el dominus, éste no sacaría provecho de la sentencia favorable del árbitro (287).

\section{EFECTOS}

\subsection{El pago de la pena}

Al hablar de la naturaleza del compromissum concluímos que de éste no surgen ni la actio iudicati ni la exceptio correspondiente. La sentencia del árbitro no es enteramente asimilable a la del juez.

Efecto único del compromissum es la obligación de las partes al pago de la pena, condicionada al incumplimiento de la sentencia, ya que a ello se comprometieron y para garantizar su cumplimiento estipularon una pena, que será abonada por la parte que, considerándose perjudicada en sus intereses, no la acate. Y por esto: a) la decisión del árbitro no da lugar a una acción ejecutiva (288), sino que es presupuesto de la actio ex stipulatu contra el que no la haya respetado; b) el compromiso 
no preclude en modo alguno la potestas agendi; la parte que no estuviera de acuerdo con el laudo arbitral podía acudir a juicio y la única consecuencia dañosa es que se exponía al pago de la pena por no haber acatado la sentencia.

La pureza de estos principios se conservó hasta época tardía, ya que todavía les encontramos consagrados en las Pauli Sententiae donde expresamente se afirma que:

ex compromisso autem iudex sumptus rem iudicatam non facit, sed si poena inter eos promissa sit, postea re in iudicium deducta, ea ex stipulatu peti potest (289).

Por ello, como acertadamente afirma Bonifacio, è giustificata ragione di stupore, leggere in qualche frammento della Compilazione giustinianea l'affermazione che del compromesso nasce anche una cosidetta "exceptio veluti pacti" (290), la cual, en modo alguno, puede ser considerada de origen clásico (291). La existencia de esta exceptio no sólo contradice a toda la estructura del instituto, sino que también es explícitamente negada en dos textos: uno, inserto en la Compilación (donde, encuadrado en el sistema justinianeo, es referido obviamente a la exceptio rei iudicatae), es de Ulpiano y en él se lee:

Ex compromisso placet exceptionem non nasci, sed poenae petitionem (292).

en el otro, extraído del Codex Gregorianus y transmitido en Cons., 9, 17, se afirma:

Qui contra arbitri sententiam petit, sola in eum poenae actio ex compromisso competit, non etiam conceptio pacti conventi.

Poniendo este fragmento en relación con la afirmación de Justiniano (Quum antea sancitum fuerat in arbitris eligendis... si quidem pro parte pulsata forma arbitralis procederet, exceptionem ei veluti pacti generari...) (293) de que la exceptio veluti pacti tiene su origen en una reglamentación del instituto anterior a él, ha llevado a Rotondi a la conclusión de que es un producto de las escuelas postclásicas orientales (294).

\subsection{Imposibilidad de apelación}

Después de la institución de la apelación, en tiempos de Augusto, no puede ser objeto de ella la sentencia arbitral. Son numerosos los rescriptos que así lo han decidido aduciendo las siguientes razones: $1^{\circ}$ Que no surge del compromiso la actio iudicati. Ahora bien, nadie puede apelar para evitar esta acción, que, en el compromiso, a nadie amenaza. $2^{\circ}$ La pena que se ha estipulado entre las partes tiene precisamente como fin el impedir un nuevo debate; el compromiso tiene por objeto poner término a un proceso y no perpetuarlo. Esta es la razón por qué el pretor lo favorece; no debiendo de servir de punto de partida a una serie interminable de apelaciones que, de magistrado en magistrado, podrán llegar hasta el emperador.

Pero las partes podrían haber sido defraudadas en su confianza; podía suceder que el árbitro se equivoque y esto era lo peor para las partes. En derecho, el árbitro no podía equivocarse, puesto que él no estaba obligado a juzgar según las leyes 
(295). De hecho, la cosa podía ser bastante frecuente, y esto obligaría a los litigantes a escoger un árbitro más entendido, más inteligente, y a él explicarle mejor sus respectivos derechos (296).

Si el árbitro había actuado de mala fe, durante mucho tiempo, nada podía hacerse para remediarlo; la sentencia, justa o injusta, se imponía. Posteriormente, se reglamentó la exceptio, de la que hemos escrito anteriormente, y que pensamos aparece en un escrito de Antonio Pío y, posteriormente, en otro de Diocleciano (297).

Para el caso de que uno de los árbitros hubiese aparecido siendo manifiestamente enemigo por otras causas, y reconvenido también con las pruebas para que no pronunciase sentencia, hubiese perseverado, no obstante, en pronunciarla sin apremiarle nadie, el emperador Antonio Pío proveyó al libelo de uno que se querelló de esto, posse eum uti doli mali exceptione (298).

Y el mismo Antonio Pío, siendo consultado por un juez, ante quien se pedía la pena, respondió por rescripto:

etiam si appellari non potest, doli mali exceptionem in poenae petitione obstaturam. Per hanc ergo exceptionem quaedam appellandi species est, quum liceat retractare de sententia arbitri (299).

Esta excepción, permitiendo al juez reformar la sentencia, suplía a la apelación.

\subsection{Compromissum y praescriptio temporis}

Durante mucho tiempo el compromiso fue considerado como algo al margen de la organización judicial, como un simple contrato. Hasta Justiniano no tuvo ninguno de los efectos que llevan consigo las distintas instancias judiciales. En particular, no tuvo el de interrumpir la prescripción. Justiniano pone fin a este estado de cosas. Aunque ni ignoramos, dice él, la opinión de Paulo, ni la de los otros iurisprudentes que han tratado de la materia que nos ocupa, decide que el compromissum hecho en presencia de un árbitro interrumpa la praescriptio temporis, como si el litigio hubiera sido llevado delante de la jurisdicción ordinaria. Justiniano no dice cuál será el punto de partida de la interrupción, pero estas palabras conventum in scriptis apud compromissarium iudicem, supondrían evidentemente la aceptación del árbitro; por lo demás, a partir de esta aceptación, es cuando el compromiso es definitivo (300).

\section{4. ¿Exceptio de litispendentia?}

Debemos tratar otra cuestión importante respecto a los efectos producidos por el compromiso. ¿Puede oponerse la exceptio de litis pendentia cuando una controversia es objeto de compromissum? En el derecho antejustiniano, que tiende a asimilar cada vez más el compromiso al juicio, podemos preguntarnos si el derecho fue cambiado sobre el particular. Ningún texto nos permite afirmarlo. Parece, más bien, que Justiniano no concedió al compromiso efecto alguno novatorio, que lo dejó, como en el derecho anterior, completamente independiente de la obligación primitiva. Así pues, entiendo que continúa teniendo fundamento la opinión mantenida por Declareuil (301) de que, incluso bajo Justiniano, el compromissum no podía 
dar nacimiento a una exceptio de litispendentia. En efecto, ambas cuestiones están estrechamente ligadas una a otra, de modo que si el compromiso no impide intentar la actio primitiva, no existe lógicamente exceptio de litispendentia. Cosa distinta ocurre en la instancia judicial, en la que las partes, comprometiéndose por la litis contestatio a obedecer a la sentencia del juez, hacen una novatio. La antigua obligatio se ha extinguido, por lo que no es posible apoyarse en ella para introducir una nueva instancia, ni antes ni después del juicio. Era, pues, natural, que, en el compromissum una causa diferente tuviera efectos diferentes.

\section{EXTINCIÓN}

Para entender plenamente la configuración romana del compromissum, es conveniente tener presente las causas de extinción del mismo, partiendo del texto fundamental de Paulo en su libro XIII ad Edictum:

Summa rei est, ut praetor se non interponat, sive initio nullum sit compromissum, sive sit, sed pendeat, an ex eo poena exigi potest, sive postea deficiat poena compromisso soluto die, morte, acceptilatione, iudicio, pacto (302).

Así pues, la primera causa de extinción sería el transcurso del plazo del tiempo que, en expresión de Talamanca, debe considerarse de escasa relevancia, ya que no plantea problema especial alguno. Por otra parte, y de acuerdo con el mismo romanista (303), el dies es inherente a la conventio compromissi, al fijar el plazo dentro del cual el árbitro puede promulgar una sentencia válida. En consecuencia, influye de forma mediata sobre las estipulaciones compromissi.

Otro supuesto de extinción del compromissum es la realización de una acceptilatio sobre la pena comprometida. En su Comentario al Edictum, Ulpiano afirma:

Pomponius ait, et si altero accepto lata sit poena compromissi, non debere eum compelli sententiam dicere (304).

Refiriéndose a la dificultad que entraña el hecho de que en el pasaje citado de Paulo aparezca el término iudicio, Talamanca ha subyarado que existe una conexión de iudicium con acceptilatio y pactum. Si estos dos últimos son hechos que extinguen una de las estipulaciones penales, aquél debe tener también la misma naturaleza. En este sentido, es natural pensar que el jurista quiso referirse a la litis contestatio sobre la actio ex stipulatu para conseguir la pena: ésta produce, por sí sola, la extinción del compromissum, ya se haya verificado o no la commissio poenae, sobre la base del efecto extintivo que le es propio en el procedimiento formulario romano (305).

La commissio poenae es otro hecho extintivo a que hace referencia Paulo diciendo:

Non cogetur arbiter sententiam dicere, si poena commissa sit,

Semel commissa poena solvi compromissum rectius puto dici nec amplius posse committi, nisi id actum sit, ut in singulas causas totiens committatur (306). 
Para entender el primero de estos pasajes citados, es preciso tener presente otro texto del mismo jurista en el que se dice que si alguno dedujera en juicio el asunto sobre el cual se hubiera otorgado el compromissum, algunos afirman que el pretor no interviene para obligar al árbitro a pronunciar sentencia, puesto que ya no puede hacer nada. Pero si esto fuera así, sucedería que aquél que se arrepintiera de haberse comprometido, podría eludir el compromiso. Por consiguiente, habrá que imponerle la pena, continuando después el pleito suo ordine ante el juez (307). Los quidam que recuerda Paulo en el texto parecen negar que, en la deductio in iudicium del objeto del compromiso, existe una violación del mismo. Sin embargo, se admite generalmente que esta parte del pasaje citado está interpolada, aunque algunos intérpretes siguen manteniendo que en el Derecho clásico podría plantearse la cuestión de si la deductio in iudicium, a que nos hemos referido, era o no una violación del compromissum (308). En cualquier caso, entiendo que este planteamiento, como ha subrayado Talamanca, debe considerarse equivocado. En efecto, la función del compromissum es asegurar a las partes la solución de la convocatoria sin recurrir a la jurisdicción ordinaria, y es evidente que el hecho de acudir a ella debe considerarse como una violación del compromissum. Así, pues, el significado de pasaje y la opinión de esos quidam deben entenderse de otro modo, tal como se indica en $\mathbf{D}$. 34,1 , que es un pasaje del mismo Paulo: el recurso al juez ordinario produce la commissio poenae, y por este motivo, habiendo tenido lugar la solutio compromissi, el árbitro ya no puede ser obligado a pronunciar la sentencia, quia iam poena non potest esse.

Por otra parte, el pasaje citado $(34,1)$ pone de manifiesto cuál podía ser el problema concreto que se planteó Paulo en aquella ocasión: aunque es posible que las partes hubieran previsto de forma expresa la commissio poenae para cada violación del compromissum, el problema que el jurista quiso abordar era el que se derivaba de la eventual aplicación al caso concreto que examinaba del principio enunciado por él mismo en otro pasaje.

Idem respondit, quotiens pluribus specialiter pactis stipulatio una omnibus subicitur, quamvis una interrogatio et responsum unum subiciatur, tamen proinde haberi, ac si singulae species in stipulationem deductae fuissent (309).

La estructura del compromissum, como conjunto de estipulaciones de las que brotan obligaciones condicionales, explica por qué se extingue también con la muerte de una de las partes, cuando ésta ha tenido lugar antes de la decisión. Así lo expresa claramente Ulpiano diciendo:

Si heredis mentio vel ceterorum facta in compromisso non fuerit, morte solvetur compromissum: nec utimur Labeonis sententia, qui existimavit, si arbiter aliquem pecuniam dare iusserit et is decesserit antequam daret, poenam committi, licet heres eius paratus sit oferre (310).

Tanto en este pasaje como en otro de Juliano (311), se alude a la posibilidad de evitar la extinción del compromissum haciendo una heredis mentio. Como es lógi- 
co, por el carácter de reciprocidad que caracteriza las dos promesas no sería suficiente que la previsión de sucesión del heredero fuera contemplada sólo por una de ellas. Por esto, la transmisibilidad del vínculo existe únicamente si en ambas estipulaciones figura esa mención del heredero.

Cuando Ulpiano se refiere a la Labeonis sententia, algunos autores piensan que este jurista negaba la intransmisibilidad del compromissum en los supuestos en que faltara esa heredis mentio. Más recientemente, Talamanca entiende que esta opinión no es aceptable en cuanto que, sobre la base precisamente de la no existencia de la mentio, sostenía que la prestación, in condicione, debía ser cumplida personalmente por la parte; al morir ésta tal prestación se hace lógicamente imposible, y la condicio, como todas las condiciones negativas in dando e in faciendo, debe considerarse entonces, y sólo entonces, como verdaderamente cumplida. En otras palabras, aplicando rígidamente las normas sobre la condicio, el jurista, constando la commissio poenae, consideraba transmisible la obligación al heredero y, apoyándose en el principio semel commissa poena non evanescitur, negaba que éste pudiera proceder a la purgatio morae (312).

Recientemente Knütel (313) ha relacionado el pasaje citado de Ulpiano con otros textos del Digesto en que se alude a las consecuencias que tiene el hecho de que se fije o no un plazo de tiempo para cumplir la sentencia, en orden a la commissio poenae. El propio Ulpiano, por ejemplo, escribe:

Intra quantum autem temporis, nisi detur, quod arbiter iusserit, committatur stipulatio, videndum est. Et si quidem dies adiectus non sit, Celsus scribit libro secundo Digestorum, inesse quoddam modicum tempus, quod ubi praeterierit, poena statim peti potest; et tamen, inquit, etsi dederit ante acceptum iudicium, agi ex stipulatu non poterit (314).

Según Knütel, en los supuestos de condena sine die adiectione, Ulpiano habría reconocido la posibilidad de subsanar el vencimiento. En los demás casos, sólo cuando el oponente se haya dispuesto a aceptar la oferta, puede desvirtuarse su acción para reclamar la pena mediante una exceptio doli. En suma, considera que Labeón se aparta en este caso de la tesis serviana.

La extinción del compromissum, finalmente tiene lugar a causa de la muerte del árbitro. Pomponio, recogiendo las enseñanzas de diversos juristas, ha explicado este hecho diciendo:

Arbiter kalendis Ianuariis adesse iussit et ante eum diem decessit: alter ex litigatoribus non adfuit. Procul dubio poena minime commissa est: nam et Cassium audisse se dicentem Aristo ait in eo arbitro, qui ipse non venisset, non esse commissam: quemadmodum Servius ait, si per stipulatorem stet, quo minus accipiat. Non committi poenam (315). 


\section{NOTAS}

(149) D. 4, 8, 7. pr.

(150) D. $4,8,9$. pr.

(151) M. TALAMANCA, Ricerche in tema di compromissum, op. cit., p. 98 ss.; ib. 37 y ss.

(152) Un supuesto distinto es referido por Juliano cuando afirma que si se hubiera con-traído el compromiso a favor de Ticio y de un esclavo, ni a Ticio se le ha de obligar a pronunciar sentencia, porque con otro recibió el compromiso (quia cum alio receperit), aunque sea nulo el arbitraje del esclavo. Inmediatamente añade: Quid tamen, si dixerit sententiam Titius? Poena non committitur, quian non, ut receperit, dixit sententiam $(D .4,8,7$, 1).

(153) D. 4, 8, 9, 1 .

(154) D. 4, 8, 41 .

(155) D. 4, 8, 41 .

(156) D. 4, 8, 9, 2.

(157) D. 4, 8, 3. y 4, 8, 4.

(158) GAYO, 1, 144.

(159) ULP., Reg. 11, 1.

(160) Ib, ib.

(161) D. 5, 1, 12, 2.

(162) C. 2, 56, 6 .

(163) D. 4, 8, 7. pr.

(164) D. 4, 8, 9, 3 .

(165) WEIZAÄCRER, Röm. Schiedsrichteramt, p. 260.

(166) M. TALAMANCA, Ricerche... op. cit., p. 134 y ss.

(167) C. $2,55,3$.

(168) D. 4, 8, 32, 14.

(169) D. 4, 8, 15 .

(170) D. $4,8,16$. pr.

(171) D. $4,8,45$.

(172) B. MATTHIASS, Die Entwicklung des römischen Schiedsgerichts, en Festschrift von Bernhard Windsscheid, 1988, p. 53.

(173) D. 4, 8, 17, 2.

(174) D. $4,8,17.4$.

(175) D. 4, 8, 18 .

(176) D. 4, 8, 17, 5 .

(177) D. $4,8,17,6$.

(178) Cf. MATTHIASS, op. cit., p. 69; C. WEIZSAECKER, Des Römische Schiedsrichteramt..., op. cit., p. 12; M. TALAMANCA, Ricerche..., op. cit., p. 140.

(179) M. MARRONE, L'Eficacia pregiudiciale della sentenza nel processo civile romano, en Annali Palermo, 24, p. 190 ss.

(180) D. 4, 8, 21.10.

(181) J. DAZA, Iniciación histórica al Derecho Romano, Alicante, 1987, p. 249 ss. 
(182) $D .4,8,32$. 6. Algún romanista se plantea dudas acerca de la clasicidad de este fragmento, por ejemplo, BESELER, Beiträge zur kritik der römischen Rechtsquellen, en 52, 66, (1948), p. 362.

(183) D. 4, 8, 32, 7.

(184) CICERÓN, Pro Ros. com., nº 6 .

(185) J. DAZA, Iniciación histórica al Derecho Romano. Alicante, 1987, p. 249 ss. Sobre la lex Calpurnia repetundarum y la lex Acilia repetundarum cfr., entre otros, TIBILETTI. Le leggi 'de iudiciis repetundarum' fino alla guerra sociale, en Athenaeum, 1953, XXXI, p. 5 ss.: SERRAO, Iudicia repetundarum, en "Studi Romani", 1934, vel II, p. 2 y ss.

(186) J. DAZA, Iniciación histórica al Derecho Romano, op. cit., p. 250.

(187) J. DAZA, op. cit., p. 250. Los crimina fundamentalmente serían los siguientes: perduellio, homicidium, crimen falsi, peculatus, vis publica, ambitus, plagium, adulterium. Estos crimina eran castigados con una pena de carácter patrimonial, o con la pena capital, que podía ser sustituida, posteriormente, por el exilio.

(188) D. 48, 4, 1, 1: Maiestatis autem crimen illud est, quod adversus populum Romanum, vel adversus securitatem eius committitur...

(189) D. 48, 8, 1: Lege Cornelia de sicariis et veneficis tenetur qui hominem occiderit...

(190) DECLAREUIL, Du compromis..., op. cit., p. 68.

(191) J. DAZA, Iniciación..., op. cit., p. 252.

(192) Acción popular penal que se ejercitaba contra aquel que alterara con dolo malo el Edicto expuesto al público.

(193) D. E, 1, 7.

(194) DECLAREUIL, Du compromis..., op cit. p. 69.

(195) D. 4, 8, 32, 7.

(196) PLINIO, Ep. ad Traj., X, 77.

(197) C. 3, 3, 2.

(198) DECLAREUIL, Du compromis..., op. cit., p. 70.

(199) C. 2, 47, 3 .

(200) D. 4, 1, 3 .

(201) D. 4, 8, 32, 7: De liberali causa compromisso facto recte non compelletur arbiter sententiam dicere, quia favor libertatis est, ut maiores iudices habere debeat... et ex fideicommissi causa libertas deberi dicatur.

(202) D. 4, 8, 32, 7 .

(203) DECLAREUIL, Du compromis..., op. cit., p. 72.

(204) Cfr. E. GÓMEZ ROYO, Los Basílicos: Origen, Estructura y Valor de la Compilación, en "Estudios S. Romeu Alfaro", Univ. Valencia, 1989, p. 451 y ss.

(205) D. 4, 8, 32, 7 .

(206) D. 4, 8, 3 .

(207) DECLAREUIL, Du compromis..., op cit., p. 74: "Il se peut, à la rigueur, que l'actio tutelae, qui fut à l'origine une actio de délit, ait conservé dans la suite, avec le caractère infamant, celui de ne pouvoir faire l'objet d'un compromis. Mais il est bien difficil d'arriver à une certitude sur cette question, qui, du reste, n'a grand intérêt".

(208) D. 11, 5, 2, 1.

(209) D. 4, 8, 21, 6. Cfr. G. BUIGES, La solución amistosa de los conflictos en Derecho Romano: El arbiter ex compromisso, Madrid, 1990, pp. 213 y 214.

(210) D. 4, 8, 46. 
(211) GLÖECK, Commentario alle Pandette, IV, Milán, 1890, p. 270 ss., solamente contempla este significado en la expresión compromissum plenum.

LA PIRA, op. cit., p. 213 señala una incoherencia entre la primera y la segunda parte del mismo, opinando que la segunda parte está interpolada. El autor distingue entre este tipo de compromissum y el compromissum de pluribus rebus de $D .4,9,21$ pr. y $D .4,8,19$, 1 .

(212) D. 4, 8, 31. BESELER. Miszellem, en SZ, 45. p. 59 considera que este texto está interpolado. En este supuesto, aunque el primer párrafo pueda considerarse clásico, el segundo (et ideo...) estaría interpolado, entonces desaparecería la expresión compromissum plenum.

(213) D. 4, 8, 11, 2.

(214) G. BUIGES, La solución amistosa de los conflictos en Derecho Romano: El arbiter ex compromisso, op. cit., p. 215.

(215) G. LA PIRA, Compromissum..., op. cit., p. 197.

(216) D. 4, 8, 32, 15.

(217) D. 4, 8, 32, 21: Arbiter nihil extra compromissum facere potest, et ideo necessarium est, adiici de die compromissi proferenda; ceterum impune iubenti non parebitur.

(218) WLASSAK, Die klassische Prozessformel, "Akad. der Wis. in Wien...", BOE B, 1924, p. 151.

(219) D. 4, 8, 1, 19.

(220) D. $4,8,17,8$.

(221) D. $4,8,21,6$.

(222) D. 4, 8, 43.

(223) CICERÓN, Pro Roscio, com. 38.

(224) CICERÓN, Pro Roscio, com. 38.

(225) D. 4, 8, 14 .

(226) D. $4,8,25$, pr. 1 .

(227) D. 4, 8, 32, 21.

(228) D. 4, 8, 32, 11.

(229) D. 4, 3, 33 .

(230) D. $4,8,25$, pr. 1. TALAMANCA, L'arbitrato romano dai "veteres" a Giustiniano, Labeo, 1974, p. 83 ss., polemiza con ZIEGLER (Das private Schiedsgericht im Antiken Römischen Recht, Munich, 1971, p. 37 ss) respecto a la opinión manifestada por éste, según la cual los adpromissores del primum compromissum no se consideran tales respecto del sequens. Para Talamanca, cl punto débil de la argumentación es la expresa determinación que hace Ziegler de la necesidad de una aceptación de la prórroga por las partes.

(231) D. 4, 8, 21, 10.

(232) D. 4, 8, 21, 10 in fine y 11 .

(233) P. Lond. 992 (año 507).

(234) D. 45, 1, 1: Stipulatio non potest confici, nisi utroque loquente; et ideo neque mutus, neque surdus, neque infans stipulationem contrahere possunt, nec absens quidem, quoniam ex audire invicem debent. Cfr. DECLAREUIL, Du compromis..., op. cit., p. 76 ss.

(235) D. 27, 10, 1: Lege duodecim tabularum prodigo interdicitur bonorum administratio; quod moribus quidem ab initio introductum est.

(236) D. 27, 10, 1: ...si talem hominem invenerint, qui neque tempus, neque finem expensarum habet, sed bona sua dilacerando et dissipando profundit, curatorem ei dare exemplo furiosi. 
(237) GAYO, I. 1. 145 afirma que las vestales estaban libres de tutela ob honorem sacerdocii. Hay que tener en cuenta que las vestales no eran sui iuris porque estaban sometidas a la potestas del pontifex maximus.

(238) GAYO, I. 1, 190.

(239) GAYO, I. 1, 154.

(240) $D, 16,1,1$.

(241) D. 4, 8, 35 .

(242) D. 44, 7, 43: ...Pupillus sine tutoris auctoritate non obligatur iure civile.

(243) D. 44, 7, 10: ... Naturales obligationes non eo solo aestimantur, si actio aliqua earum nomine competit, verum etiam eo, si soluta pecunia repeti non possit.

(244) D. 4, 8, 47.

(245) D. 44, 7, 43.

(246) D. $4,8,32,8$. TALAMANCA, op. cit., 131.

(247) D. $15,1,3,8$.

(248) D. 4, 8, 1 .

(249) D. 15, 1, 3, 10.

(250) D. 26, 7, 2: Si tutor condemnavit, sivi ipse condemnatus est, pupillo et in pupillum potius actio iudicati datur...

(251) D. 26, 7, 35: A tutoribus et curatoribus pupillorum eadem diligentia exigenda est, circa administrationem rerum pupillarum, quam pater familias rebus suis ex bona fide praebere debet.

(252) D. 4, 8, 17.

(253) $1.4,10$, pr.

(254) La fecha exacta de esta ley es desconocida, si bien Huvelin la sitúa en el s. I d. C.

(255) GAYO, $I, 4,9,97$.

(256) Traspaso que realizaba el propio magistrado, mediante las llamadas fórmulas con trasposición de personas.

(257) D. 4, 8, 39 .

(258) D. 4, 8, 27, 4: Si quis litigatorum disfuerit, quia per eum factum est, quo minus arbitretur, poena committetur.

(259) DECLAREUIL, Du compromis..., op. cit. p. 125.

(260) D. 4, 8, 27, 5: ...coram pupillo non videri sententiam dictam, nisi tutor praesens fuit.

(261) D. 4, 8, 49: sed et interpellatur, quo minus sententiam dicat, quia nihil coram furioso fieri intelligitur. Quodsi furiosus curatorem habet, vel habuerit adhuc litigio pendente, potest praesente curatore sententia dici.

(262) D. 4, 7, 28. pr.

(263) D. $4,8,40$.

(264) D. 4, 8, 21.

(265) D. 4, 8, 40 .

(266) D. 4. 8. 21.9.

(267) D. 4, 8, 23. 1.

(268) DECLAREUIL, Du compromis..., op. cit, p. 128.

(269) D. 4, 8, 21, 9 .

(270) D. $4,8,23$, pr. 2.

(271) D. 4, 8, 27, 6 .

(272) D. 4, 8, 30 .

(273) D. 5, 1, 30 . 
(274) C. Gr. I, 10, 5.

(275) I. 4, 12, 2.

(276) D. 4, 8, 27, 2.

(277) D. 4, 8, 23.

(278) D. $4,8,38$.

(279) D. 4. 8.23. 3.

(280) D. 4, 8, 24.

(281) DECLAREUIL, Du compromis..., op. cit., p. 135.

(282) D. 4, 8, 27, 1 .

(283) D. 4, 8, 21, 12 .

(284) D. 4, 8, 23.

(285) D. $4,8,23,1$.

(286) D. 4, 8, 27, 1 .

(287) D. 4, 8, 29 y 34.

(288) PAUL. SENTENTIAE, 5, 5, 1; 2. 55, de rec. 1: ...nec iudicati actio inde praestari potest...

(289) PAUL . SENTENTIAE, 5. 5*. 1.

(290) F. BONIFACIO, voz Compromesso, Nov. Dig. p. 784. Los textos a que se refiere el autor son $D .4,8,13,1$ y $C .2,55,5$ pr.

(291) G. ROTONDI, L'exceptio veluti pacti ex compromisso, en "Scritti Giuridici", I, p. 284 ss. Cfr. el epígrafe 2.5 de este capítulo donde henos tratado ampliamente de la exceptio pacti ex compromisso.

(292) D. 4, 8, 2.

(293) C. 2, 55, 5 pr.

(294) G. ROTONDI, L'exceptio veluti pacti ex compromisso, op. cit., p. 284 ss.

(295) Cfr. el epígrafe 4. 3. 3: La decisión del árbitro. Problemas que plantea.

(296) D. 4, 8, 32, 14.

(297) C. $2,3$.

(298) D. 4, 8, 32, 14.

(299) D. 4, 8, 32, 14 .

(300) C. 2, 5, 1 .

(301) DECLAREUIL, op. cit., p. 141.

(302) D. 4, 8, 32, 3 .

(303) M. TALAMANCA, Richerche..., op. cit., p. 74.

(304) D. 4, 8, 13 pr.

(305) M. TALAMANCA, Richerche..., op. cit., p. 76.

(306) D. $4,8,34,1$.

(307) D. 4, 8, 30 .

(308) Cfr. ROTONDI, Exceptio pacti..., op. cit., p. 293, n. 1.

(309) D. 45, 1, 134, 3; Cfr. TALAMANCA; Ricerche..., op. cit., p. 78; el autor disiente de Riccobono, que consideraba la primera parte de este pasaje interpolada. Según él, en el párrafo primero se establece que los acuerdos que tuvieron lugar en el período previo a la stipulatio deben entenderse incluidos en ella. En el párrafo tercero, en cambio, se plantea un problema diferente, a saber, si la única stipulatio, sometida a una serie de acuerdos, debe entenderse como uno solo o como varios negocios. Este problema, por otra parte, está tratado en una serie de pasajes en que aparece clara la capacidad de la Jurisprudencia romana para entender una pluralidad de negocios, cuando ello corres- 
ponda a la intención práctica de las partes (véase en tal sentido $D .45,1,1,5 ; 45,1,1,29$ pr. y otros pasajes). Probablemente, la misma cuestión se planteaba para la stipulatio poenae que desempeñaba la misión de garantía para las múltiples pretensiones asumidas por las partes con el compromiso. $\mathrm{Y}$ es evidente que si, bajo este aspecto, se hubiera reconocido la possibilità di un'iterazione della "comissio poenae", non si sarebbe potuti arrivare alla conclusione che il compromesso dovesse considerarsi estinto (ib. p. 79).

(310) D. 4, 8, 27, 1 .

(311) D. 4, 8, 49, 2.

(312) M. TALAMANCA, Ricerche..., op. cit., p. 89.

(313) R. KNÜTEL, Stipulatio Poenae, Köln-Wien, 1976, p. 148 ss.

(314) D. 4, 8, 21, 12 .

(315) D. 4, 8, 40. 


\section{SOBRE LA CAPACIDAD AUTONORMATIVA DE LAS UNIVERSIDADES}

(Comentario a la STC 130/1991 de 6 de Junio)

JUAN JOSE DIEZ SANCHEZ

Profesor de Derecho Administrativo

Facultad de Derecho Universidad de Alicante

\section{HECHOS.-}

El Claustro Constituyente de la Universidad de Valencia, adoptó el acuerdo de establecer el emblema o escudo de la universidad, suprimiendo del tradicional existente la imagen de la Virgen de la Sapiencia que aparecía en su parte central superior.

Este acuerdo fue adoptado en dicho órgano intrauniversitario, con la oposición de diversos claustrales que defendían mantener aquella figura que secular e ininterrumpidamente habia figurado en el Escudo de la Universidad valenciana, y refrendado por Decreto del Consell de la Generalidad Valenciana 172/1985 de 28 de Octubre que aprobó sus Estatutos.

Tras agotar la vía administrativa sin éxito, diversos miembros del Claustro recurrieron el citado acuerdo y el Decreto del Consell ante la jurisdicción contenciosoadministrativa. En esta sede, la Audiencia Territorial de Valencia estimó el recurso y anuló ambas decisiones tanto en lo referente a la supresión de la Virgen, como en lo relativo al empleo de la expresión "Emblema" que debía ser sustituída por la de "Escudo".

La Universidad y la Generalidad recurrieron en apelación la sentencia ante el Tribunal Supremo, y la Sala Segunda de éste desestimó los recursos, confirmando integramente la decisión apelada.

Contra ambas sentencias, la Universidad de Valencia interpuso recurso de amparo por entender vulnerado el derecho a la autonomía universitaria reconocido en el art. 27. 10 de la C.E., que el Tribunal Constitucional (TC) otorga en la Sentencia 130/1991 de 6 de Junio, objeto de este comentario.

\section{EL AMPARO CONSTITUCIONAL.-}

Por lo que más tarde se indica en torno a la parte dispositiva de esta Sentencia, resulta de interés exponer ahora sucintamente las alegaciones formuladas por las distintas partes en el proceso de amparo constitucional.

La actora (Universidad) alega y argumenta básicamente, según se describe en los antecedentes, lo siguiente: 
"a). Que el derecho fundamental del art. 27.10 de la C.E. faculta a la Universidad de Valencia para establecer su emblema o escudo en la forma acordada por el Claustro Constituyente, sin sujetarse a antecedentes históricos o tradicionales y sin más limitaciones que las contenidas en la Ley de Reforma Universitaria, o las exigidas por otros derechos fundamentales, la necesaría coordinación, el concepto de servicio público de la Universidad y el cumplimiento estricto de la legalidad vigente.

b). Que ningún derecho fundamental se ha conculcado con la decisión por el Claustro del símbolo o escudo universitario mediante un Acuerdo válidamente adoptado en el ejercicio de la autonomía universitaria, que no puede anularse por la sóla circunstancia de no hacerse constar en la certificación del acta de la sesión cuáles documentos se tuvieron en cuenta y cuáles no, puesto que todos los que estaban en el expediente deberían haber sido conocidos por los miembros del órgano colegiado constituyente.

c). Que siendo cierto que el ejercicio de la autonomía administrativa debe estar subordinado a un interés público cuando se está ante actos administrativos o declaraciones de voluntad de la Administración susceptibles de producir efectos jurídicos sobre los administrados, tal cosa no ocurre respecto del acto o acuerdo de un órgano de un ente público por el cual se fija el símbolo del mismo, al ser éste más que un acto administrativo un acto de la Administración que no produce efectos jurídicos ni altera la situación jurídica subjetiva de los administrados, por lo que no puede verse la autonomía universitaria limitada por la necesidad de justificar cualquier cambio en esta materia por el interés público."

La Generalidad Valenciana reitera -dándolas por reproducidas- esas mismas alegaciones.

Los impugnantes de la decisión basan sus alegaciones en los siguientes extremos:

"a). El art. 12 de los Estatutos, al suprimir la imagen mariana del escudo de la Universidad de Valencia, carece de toda explicación racional, no habiéndose aportado ningún motivo material, jurídico, académico o histórico que lo justifique, pues el derecho fundamental de autonomía universitaria no excluye las limitaciones que le imponen otros derechos o principios constitucionales como los comprendidos en los arts. 9.1 y $3 ; 103.1$; y 106.1 de la C.E.

b). El Acuerdo del Claustro por el que se suprime del escudo de la Universidad la imagen de la Virgen de la Sapiencia no puede fundamentarse en el principio de autonomía universitaria, careciendo de causa jurídico-administrativa por no corresponder a ningún interés público que afecte a los principios de libertad de cátedra, libertad de investigación y libertad de estudio, por lo que vulnera también el art. 27.10 de la C.E. y los arts. 2 y 3.1 de la Ley de Reforma Universitaria."

Por su parte, el Ministerio Fiscal fundamenta las suyas, resumidas, en:

"a)...destaca la poca concreción con la que la parte actora invocó los derechos fundamentales que aquí se hacen valer en el escrito de alegaciones efectuado en el recurso de apelación, donde para nada se cita la autonomía de la Universidad; si 
bien entiende que hay que tener por invocado dicho derecho fundamental por la remisión efectuada a la alegación cuarta de la Generalidad de Valencia, que cita el art. 27.10 de la C.E."

b) recuerda la doctrina del TC "sobre la autonomía universitaria como garantía institucional y derecho fundamental, y advierte que desde la óptica constitucional hay que reconocer al Claustro Constituyente la facultad, derivada de su autonomía universitaria, de acordar los escudos o emblemas que estime más pertinentes, sin más necesidad que la de obtener una mayoría suficiente para la libre formación de la voluntad de sus integrantes, pues lo contrario conduciría a la práctica negación de un ámbito autónomo en cuestiones que son meramente internas de la Universidad".

La apreciable comunicación de argumentos, tanto de índole constitucional (fundamentalmente el art. 27.10, pero también los arts. 9.1 y 3; 103.1 y 106.1 C.E.) como legal (arts. 2 y 3.1 LRU, e hipotéticas infracciones procedimentales a las que implícitamente se alude en algunas de las alegaciones referidas), resultan dificilmente comprensibles sin tener en cuenta los planteamientos y resoluciones previos de los Tribunales ordinarios recaídos en el objeto en litigio.

A ellos hace expresa mención la STC. Con parca referencia en relación a la SAT de Valencia de 11 de Diciembre de 1987, ya que únicamente recoge que esa decisión anula el artículo correspondiente de los Estatutos de la Universidad, declarando además que la palabra "Emblema" "es contraria de Derecho y por tanto jurídicamente inaplicable, por falta de idoneidad y sentido correcto en el presente caso y que debe ser sustituída por la de "Escudo" de la Universidad de Valencia, como denominación correcta legal...".

Con mayor detalle en relación a la STS de 12 de Junio de 1990 que reconoce: de una parte, la violación del art. $47.1 \mathrm{c}$ ) de la LPA porque "no consta en el acta de la sesión en que fue aprobada la supresión de la imagen que antes existía en el Escudo de la Universidad ni en la orden de convocatoria, que los asistentes al acto tuvieran a su disposición los escritos de los Catedráticos, Profesores, Ex-Alumnos y Alumnos de la Universidad en que expresaban sus razones para oponerse a dicha supresión en el Escudo de la Universidad; asimismo no consta tampoco que se pusieran de manifiesto los Informes de las Reales Academicas de Medicina y de Bellas Artes de San Carlos... que de forma unánime y motivada eran contrarias a la supresión de dicha imagen en el escudo en cuestión; con lo que, al no poder tener en cuenta muchos de los miembros del Claustro Constituyente, para la formación de la voluntad individual de cada uno de ellos, el contenido explícito de los referidos Informes, no pudo formarse adecuadamente ésta y, por ende, la voluntad colegiada del Organo que produjo el acto de aprobación de los Estatutos de actual referencia".

De otra, por conculcar el art. 9.3 de la C.E. en lo relativo a la "interdicción de la arbitrariedad de los Poderes públicos", pues falta en el acto administrativo "causa jurídica" fundada en un interés público o en un interés del servicio público de la docencia al que la Universidad de Valencia viene obligada a prestar conforme a la legislación vigente", y ello "porque en el expediente administrativo no consta fundamento objetivo, razonamiento ni demostración alguna, que jurídicamente justifique 
que la supresión de la tradicional y aludida imagen de la Virgen de la Sapiencia en el Escudo o Emblema de la Universidad haya de ser procedente..."; "y sin embargo,la Administración trata de fundamentar dicha supresión, solamente en la aconfesionalidad religiosa del Estado que determina la Constitución y en la voluntad del Claustro Constituyente de la Universidad, producida democráticamente, y en uso del principio de autonomía de la Universidad que la Constitución y la Ley Orgánica de la Reforma Universitaria le confieren; más lo cierto es que con ello no se justifica que la actuación administrativa se hubiera realizado en función de un interés público o en función de un interés de servicio público que la actividad de la Universidad en cuestión entraña...".

\section{LA FUNDAMENTACION JURIDICA DEL TRIBUNAL CONSTITUCIO- NAL.-}

Teniendo en cuenta los diferentes aspectos antes enunciados que se ventilan en esta STC, distribuímos este apartado en dos partes de distinto alcance, haciendo las valoraciones pertinentes al hilo de la exposición de la fundamentación jurídica del Alto Tribunal.

\section{Observaciones peliminares.-}

Dos observaciones de distinto signo se plantea el TC como paso previo al estudio de la cuestión de fondo planteada: la primera de ellas, estrictamente procedimental, referida al cumplimiento del requisito exigido por el art. 44.1. c) de su Ley Orgánica; la segunda, de mayor enjundia, relativa al contenido de la autonomía universitaria y su alcance.

\section{a). La invocación formal de derecho constitucional vulnerado.-}

La exigencia sancionada en el precitado art. 44.1. c) de la LOTC ("Que se haya invocado formalmente en el proceso el derecho constitucional vulnerado, tan pronto, una vez conocida la violación, hubiere lugar a ello") como requisito procedimental para la interposición y aceptación del recurso de amparo, carece en este supuesto de relevancia, o si se prefiere, tiene escaso relieve.

El origen del mismo se debe al planteamiento formulado por el Ministerio Fiscal -alegación antes citada en la letra a)-, acerca de la "escasa concreción de la invocación formal en el proceso del derecho constitucional supuestamente vulnerado".

Esta objeción, que la propia fiscalía entiende se halla eliminada por la remisión que la actora (Universidad de Valencia) hace en el recurso de apelación a la alegación cuarta de la Generalidad Valenciana referida precisamente al art. 27.10 C.E., es despachada por el TC entendiendo cumplido el trámite procedimental preceptivo, con un doble argumento. De un lado, porque la Universidad "comenzó sus alegaciones de apelación ante la Sala Tercera del Tribunal Supremo manifestando que el acto objeto del recurso constituye un elemento básico de sus facultades, enmarcado 
dentro del derecho constitucional de autonomía". De otro, porque por razones de economía procesal "y en cuanto a la posible desviación de poder del Claustro Constituyente" la Universidad se remite a las alegaciones formuladas por la Generalidad, con invocación expresa -por esta última- del art. 27.10 C.E.

Ambos datos resultan suficientes para estimar cumplido el trámite procedimental, sin requerir mayor desarrollo, dado que únicamente el Fiscal advertía esa reserva y como vimos el mismo reparaba en su irrelevancia en este caso.

Cierto es, además, que la jurisprudencia constitucional ha tenido oportunidad en reiteradas ocasiones de pronunciarse sobre el cumplimiento de los requisitos formales de acceso al recurso de amparo y, en especial, el de invocación del derecho fundamental vulnerado, en una línea poco formalista. Así, en las sentencias de 26 de Enero y 30 de Marzo de 1981 señala que si bien la invocación formal no requiere la mención del artículo concreto de la Constitución en que se proclama el derecho, ni siquiera la de su nomen iuris, sí ha de ofrecer base suficiente para que, en la vía judicial, pueda entrarse a conocer de las concretas vulneraciones aducidas, lo que requiere, al menos, una delimitación del contenido del derecho que se dice violando. Por su parte, las SSTC 47/1982 de 12 de Julio y 10/1986 de 24 de Enero, explicitan que del hecho de que el art. 44.1. c) hable de una invocación formal del derecho no se desprende que para entender cumplido el requisito legal hya de llenarse un determinado formalismo, pues el recurso de amparo no puede estar rodeado de más exigencias formales que aquéllas que requiera su recto funcionamiento, debiendo por ello interpretarse con criterio finalista, de manera que no debe tratarse de una invocación numérica de un artículo del texto fundamental, sino del derecho cuya violación se pretende cometida. Resume esta doctrina la reciente STC 176/1991 de 19 de Septiembre.

El citado requisito determinador del carácter subsidiario que como medio de protección de los derechos fundamentales tiene el recurso de amparo en relación al procedimiento judicial ordinario, se entiende hecho con la STC 106/1984 aún cuando falte referencia alguna a un precepto concreto de la Constitución, pues "a partir del planteamiento explicito de la cuestión jurídicoconstitucional, hay que entender que juega con toda plenitud el principio iura novit curia" (fundamentación expresada en la STC 11/1982 de 29 de Marzo).

Ahora bien, parece en efecto, que la concisa o parca invocación en apelación era evidente, pues el TC -con los argumentos de la fiscalía- conviene en valorar que "acaso pudiera explicar la asimismo escasa atención dispensada por el Tribunal Supremo a la autonomía universitaria en su resolución confirmatoria de la Sentencia apelada".

b). El contenido y alcance de la autonomía universitaria.-

La segunda observación preliminar permite al TC "enfocar el presente recuso de amparo y calibrar debidamente el fundamento de la queja constitucional deducida", presuponiendo, sin duda, la antesala necesaria para la fundamentación esencial de la presente sentencia.

Partiendo de que, en definitiva, la cuestión planeada "se ciñe a determinar si las 
resoluciones judiciales vulneran o no el derecho a la autonomía de la Universidad de Valencia, reconocido en el artículo 27.10 de la C.E." (1), el TC advierte "que el problema suscitado no estriba en determinar si, dentro del ámbito de la autonomía universitaria que la Constitución reconoce y garantiza, se incluye o no la capacidad de la Universidad para elaborar sus propios símbolos o darse a sí misma la representación emblemática que estime más conveniente".

Por el contrario, dirá más tarde, "lo que se ventila en este proceso constitucional no es tanto el ámbito o el contenido material de la autonomía universitaria, sino más bien el alcance del control judicial de una concreta decisión adoptada por dicha institución en el ejercicio de su autonomía, de suerte que el objeto del presente recurso de amparo no es determinar si la capacidad de elegir sus propios simbolos constituye o no una extralimitación de la autonomía universitaria, sino decidir si la revisión jurisdiccional llevada a cabo por el órgano jucial del acuerdo adoptado por el Claustro Constituyente interfiere la autonomía universitaria o, por el contrario, se ciñe a los márgenes de fiscalización y control que el derecho constitucional de autonomía permite a la intervención judicial".

Con estas premisas, el Alto Tribunal da logicamente por supuesto que el contenido atribuido a la autonomía universitaria alcanza a la fijación o establecimiento de sus símbolos identificadores o representativos. Para ello se apoya en la propia jurisprudencia constitucional contenida en las sentencias 26/1987 de 27 de Febrero, 55/1989 de 23 de Febrero y 106/1990 de 6 de Junio, que han concretado el sentido y alcance de aquel derecho fundamental (2), y en la propia naturaleza de las cosas.

En el primero de los apoyos, el TC se limita a señalar alguno de los puntos esenciales en que se ha concretado la autonomía universitaria, sin excesivas matizaciones, posiblemente por la lógica presunción de que se arranca. Si la autonomía universitaria -dirá retomando las fundamentaciones de las sentencias precitadas- "se concibe como un derecho de estricta configuración legal, la Universidad -una vez delimitado legalmente el ámbito de su autonomía- posee en principio plena capacidad de decisión en aquellos aspectos que no son objeto de regulación específica èn la Ley, y resulta asimismo patente que la concreción de este derecho fundamental se materializó con la aprobación de la Ley de Reforma Universitaria que, básicamente en su art. 3, ha precisado el conjunto de facultades que dotan de contenido al derecho fundamental de autonomía universitaria; facultades entre las que se encuentra la potestad de autonormación entendida como la capacidad de la Universidad para dotarse de su propia norma de funcionamiento o, lo que es lo mismo, de un ordenamiento específico y diferenciado, sin perjuicio de las relaciones de coordinación con otros ordenamientos en los que aquel necesariamente ha de integrarse".

El legislador dispone, pues, -como advierte LEGUINA VILLA- (3) de una amplia libertad de configuración de la autonomía universitaria, pero, una vez que ha fijado sus opciones, todo lo que no esté regulado pertenece al contenido normal de la autonomía de cada Universidad. No parece entenderlo así, sin embargo, la reciente STS de 17 de Julio de 1991, empleando una pobre y confusa fundamentación dificil de compartir. 
En el segundo, el TC concluye a la vista de esa jurisprudencia "que la capacidad de la Universidad valenciana para adoptar su escudo, sello o símbolos de identidad y representación en modo alguno desborda las facultades legalmente asignadas a la institución universitaria, sino que se comprende con evidencia y naturalidad en el contenido normal de la potestad de autonormación en la que también se concreta su autonomía".

No nos ofrece duda alguna la acomodación al contenido de la autonomía universitaria, de la capacidad de cada Universidad para establecer sus símbolos de identificación y representación. Y, consecuentemente entendemos que la decisión, en cuanto al fondo, se ajusta al alcance de ese derecho constitucional. Coincidimos, plenamente, por tanto, con el TC en este sentido, y con la fundamentación en que se ampara.

No obstante, cabe disentir parcialmente de lo indicado en el texto al advertir la omisión de planteamientos discrepantes. En efecto, se afirma que el problema suscitado no estriba en determinar si la autonomía universitaria incluye o no la capacidad de la Universidad para elaborar sus propios símbolos (es decir, si forma parte de su contenido material); sino decidir si la revisión jurisdiccional se ciñe o no a los margenes de fiscalización y control de aquel derecho constitucional. Con mayor rigor, se precisa que lo debatido es "el modo en que el Claustro universitario constituyente se valió de ella para modificar la simbología que venía identificando a la Universidad valenciana", y que ninguna de las partes discute aquella capacidad.

Al respecto, sin embargo, habría que señalar que sí parece que lo discuten los recurrentes de la decisión adoptada por el Claustro, por cuanto estiman que el acuerdo vulnera las limitaciones que al derecho de autonomía universitaria imponen otros derechos o principios constitucionales; más aún que la decisión no puede fundamentarse en el principio de la autonomía universitaria que ellos concretan en los de libertad de cátedra, de investigación y de estudio (veáse antecedentes expuestos).

Precisamente el recurso de amparo y la primera de las alegaciones de la Universidad de Valencia se centran en rechazar esas afirmaciones, dirigiéndose las restantes a atacar los fundamentos de las resoluciones judiciales. Y ciertamente aquéllos -en lo que constan en la STC- no cuestionan el derecho a la autonomía universitaria, sino que se basan en el uso que de la misma ha hecho la Universidad de Valencia.

Se advierte aquí, a nuestro entender, un planteamiento erróneo por parte de los sujetos que discreparon del acuerdo adoptado, que no merece ninguna atención al TC. Esto es, la confusión de lo que debe entenderse como núcleo básico o contenido esencial de la autonomía universitaria garantizado por el art. 27.10 C.E., y las facultades o potestades autonormativas que se reconocen ex lege a cada Universidad. En el primero de los aspectos, es cierto que el contenido esencial se halla integrado por "todos los elementos necesarios para el aseguramiento de la libertad académica" lo que coincide básicamente, según la STC 26/1987 de 27 de Febrero, con las potestades que el art. 3 LRU atribuye a las Universidades (4). Es razonable sostener, desde esta perspectiva, que los simbolos antes referidos no forman parte de ese contenido, 
que no guardan relación directa -ni tal vez indirecta- con la libertad académica cuya preservación es ineludible para reconocer el derecho fundamental como tal.

Ahora bien, al margen del citado contenido esencial, la configuración de la autonomía universitaria como derecho de estricta configuración legal, permite reconocer a las Universidades potestades autonormativas en aquellos otros aspectos que no han sido específicamente regulados por el legislador. Supuesto en el que cabe incluir el establecimiento de los símbolos o escudos, ya que lo permiten las previsiones legales y a ello no se oponen los restantes límites que enmarcan la autonomía universitaria.

\section{La vulneración del derecho a la autonomía universitaria.-}

Dos son las razones en que se fundamenta el TS para confirmar la sentencia apelada, las cuáles van a ser rechazadas por el TC por constituir otras tantas vulneraciones del derecho fundamental invocado.

a). La presunta nulidad del acto impugnado.-

Se trata en este caso de la apreciación por el órgano judicial de determinados vicios procedimentales presuntamente cometidos por el Claustro constituyente en la sesión en que fue aprobada la supresión de la imagen que existía en el Escudo de la Universidad de Valencia.

¿Cuál es este vicio que lleva al TS a declarar la nulidad de preno derecho del acto? Se trata, según se expuso en los antecedentes, de la violación del art. 47.1. c) de la LPA, por, en definitiva, estimar infringidas las "normas esenciales para la formación de la voluntad de los órganos colegiados".

Estamos, pues, como subraya el TC, ante una nuestión de "mera legalidad" o de "legalidad ordinaria", cuya interpretación y aplicación compete a los Jueces y Tribunales en el ejercicio exclusivo de la potestad que les reconoce el art. 117.3 C.E., pero que cae bajo el alcance del Alto Tribunal cuando la decisión adoptada viole algún derecho o garantía constitucional, "situación que es la acaecida en el presente caso".

¿De dónde surge la violación constitucional que cabe reprochar a la decisión judicial?.

He aquí la reflexión constitucional, descendiendo al plano de los hechos: "No indaga el órgano judicial en las actuaciones ni en la documentación obrante en autos para verificar si los referidos escritos e informes se hurtaron al conocimiento de los claustrales o estuvieron, en cambio, a su libre disposición, pues no cabe razonablemente dudar que el contenido de unos y otros hubo de ser -o pudo serlo, al menossuficientemente aireado y esgrimido en los debates previos a la votación por quienes defendieron la opción que, efectuada aquélla, resultó ser la minoritaria del Claustro. No niega en ningún momento el órgano judicial que los documentos, informes o dictámenes estuvieran incorporados al expediente, ni que éste estuviera en todo momento a disposición de los claustrales, sino que radica el vicio sustancial del procedimiento en el insuficiente contenido del acta de la sesión. No se afirma, 
pues, en ningún momento que hubiera desconocimiento u ocultación de documentos existentes en el expediente, ni que se impidiese la libre discusión y decisión por parte del claustro, en que reside la principal garantía del prodecimiento, sino que en el acta no consta que todos los claustrales tuvieran de hecho presentes todos los documentos. Así las cosas, el vicio no se sitúa en el momento de la formación de la voluntad del Claustro sino en otro posterior a la misma y meramente formal".

Nos encontramos aquí ante un reproche sustancial y una interpretación jurídica, no por obvias menos interesantes, y ante una presunta reducción de la infracción cometida por el órgano constituyente universitario.

El reproche al Tribunal "a quo" es sustancial y descriptivo. No indaga, no niega, no se afirma, comienzan los tres párrafos de esta fundamentación, censurando que aquél se haya limitado a dar la razón a los apelados, sin advertir hasta qué punto la infracción invocada ha sido o no cometida. No existe, a lo que se deduce, actividad por parte del Tribunal para comprobar -ia la vista de los autos!- si la infracción se había o no producido.

La interpretación jurídica deriva de la no menos evidente subsunción que el TS efectúa del vicio de nulidad del art. 47.1. c) de la LPA. El TC se ve obligado por esa causa a determinar que ese vicio no se produce porque en el acta no conte que todos los claustrales tuvieran de hecho presentes todos los documentos, momento que califica de posterior y meramente formal, sino que el vicio para que produzca el efecto de nulidad radical ha de situarse en el momento de la formación de la voluntad del órgano colegiado. Hay que coincidir por entero con tal exégesis, que concuerda con el entendimiento que merecen las reglas esenciales para la formación de la voluntad de los órganos colegiados contenidas en los arts. 9 a 15 LPA, con las salvedades que, en su caso, pudiera haber introducido la propia normativa intrauniversitaria.

De cualquer forma debe observarse que esta circunstancia no resulta aún decisiva en el caso comentado, por cuanto queda por precisar el caracter que tenían otros requisitos condicionantes de la válidez del acuerdo adoptado.

Debemos, por esa razón retomar la línea argumental para explicar este fallo judicial -y el correspondiente error interpretativo, absolutamente formal-, teniendo en cuenta la argumentación manejada por el TS en su sentencia. Ello, por otra parte, nos da pie a advertir aquella presunta reducción antes aludida.

El TS no se basa únicamente en la constancia o no en el acta de todos los documentos. Ese es uno de los apoyos -incorrecto, ciertamente, por sí solo, para fundar la violación del art. 47.1. c) LPA. Se basa también en la omisión en la orden de convocatoria de aquellos extremos, así como en la no constancia de que se pusieran de manifiesto ciertos informes (si bien, esto último, puede reconducirse al primer punto).

¿En qué medida esta reducción alteraría las cosas?. Es dificil con los datos que se manejan dar una respuesta convincente. A pesar de ello, cabe aludir a estas dos alternativas: que el orden del día hubiera sido elaborado debiendo contar con las peticiones de los miembros del Claustro formuladas con la suficiente antelación 
(art. 10.2 LPA), o que éstas últimas no existieran. Esto es, remitiendo al carácter preceptivo o no de la configuración del orden del día, con la documentación respectiva.

Si fuera del primer modo, no cabe duda de que estaríamos ante el supuesto prefijado en el art. 47.1. c) LPA, con las consecuencias extraídas por el TS. Sí, contrariamente -y es lo que parece- estamos ante la seguda alternativa, la inaplicación del antecitado artículo es evidente o manifiesta.

De esta última forma lo entiende el TC para, a pesar de no pronunciarse sobre la cuestión concreta de la confección del orden del día, estimar que la decisión del TS invade y afecta a un derecho fundamental. "Este Tribunal, -nos dice-, que tiene vedado revisar o entrar a conocer de los hechos que dieron lugar al proceso, no debe, en cambio abstraerse de las consecuencias jurídicas que el órgano judicial extrae de los mismos cuando, viéndose afectado un derecho fundamental, tales consecuencias resulten desproporcionadas o supongan para el derecho fundamental en cuestión una injerencia, sacrificio o menoscabo en modo alguno justificado, razonable o, simplemente acorde con la naturaleza y gravedad de la infracción o irregularidad producida. Justo esto es lo que acontece en el presente caso donde el necesario juicio ponderativo y la adecuada valoración de las exigencias inherentes al derecho fundamental de la autonomía universitaria, conduce a concluir que, no estando afectado ningún otro derecho fundamental, el de autonomía universitaria que consagra el art. 27.10. de la CE no puede quedar enervado por la sola circunstancia de no hacerse constar en la certificación del acta de la sesión qué documentos se tuvieron en cuenta y cuáles no, puesto que -como alega la Universidad actora- todos los que estaban en el expediente deberían haber sido conocidos por los claustrales o, por lo menos, y sin duda alguna, pudieron serlo. Es evidente, en fin, que la no constancia en acta de escritos e informes no preceptivos no autoriza a concluir que unos y otros no fueron conocidos en la defensa y en el debate de las diferentes posiciones del Claustro, finalmente zanjado por el acuerdo mayoritario del órgano colegiado constituyente. En consecuencia, el primer reproche judicialmente apreciado contra la validez del acuerdo en cuestión debe ser desechado".

Dos extremos merecen ser remarcados en este párrafo decisivo de la sentencia que comentamos. De un lado, la consideración negativa de la decisión adoptada por el TS, que puede juzgarse -y así lo da a entender el TC- de injustificada e irrazonable desde la perspectiva del derecho fundamental a la autonomía universitaria. De otro, y este es susceptible de mayor énfasis, el razonamiento especialmente simple dado que no es necesario apurar el planteamiento- que hace el TC de que la supuesta irregularidad formal no puede enervar el indicado derecho fundamental.

b). La presunta "arbitrariedad" de los poderes públicos.-

E1 TS confirma también la decisión del Tribunal "a quo", entendiendo vulnerado el art. 9.3ำ $\mathrm{CE}$ por faltar en el acto administrativo "causa jurídica" fundada en un interés público.

La razón de tal proceder deriva de que "en el expediente administrativo no consta fundamento objetivo, razonamiento ni demostración alguna que jurídicamen- 
te justifique que la supresión de la tradicional y aludida imagen... haya de ser procedente".

Frente a este argumento, absolutamente razonable en general en torno al actuar administrativo, el TC enfatiza su rechazo con dos consideraciones de diferente entidad y plena comprensión.

La primera de ellas, de estricta legalidad, trae causa de la previsión del art. 12.1 LRU, en virtud del cual los Estatutos de las Universidades habrán de ser aprobados "si se ajustan a lo establecido en la presente Ley". Esto es, la Ley admite un control de legalidad, pero no cabe "un control de oportunidad o conveniencia, ni siquiera de caracter meramente técnico dirigido a perfeccionar la redacción de la norma estatutaria", como dejaron sentado las SSTC 26/1987 y 55/1989 que ahora trae a colación la decisión comentada.

La fundamentación de esta conclusión constitucional la reflejó con absoluta nitidez la STC 55/1989 con su caracterización de los Estatutos Universitarios como "reglamentos autónomos" (5). Aunque éstos, dirá esa decisión, "tenga su norma habilitante en la LRU, no son, en realidad, normas dictadas en su desarrollo; son reglamentos autónomos en los que se plasma la potestad de autoordenación de la Universidad en los términos que permite la Ley. Por ello, a diferencia de lo que ocurre con los reglamentos ejecutivos de leyes que para ser legales deben seguir estrictamente el espiritu y la finalidad de la ley habilitante que les sirve de fundamento, los Estatutos se mueven en un ámbito de autonomía en que el contenido de la Ley no sirve sino como parámetro controlador o límite de la legalidad del texto. $\mathrm{Y}$ en consecuencia, sólo puede tacharse de ilegal alguno de sus preceptos si contradice frontalmente las normas legales que configuran la autonomía universitaria, y es válida toda norma estatutaria respecto de la cuál quepa alguna interpretación legal".

Sobre esa base previamente conocida, al Alto Tribunal discurre ya sin inconvenientes que "en el caso que nos ocupa no hay que buscar causa jurídica o interés público justificativos de la voluntad claustral más allá de ella misma. Ni ésta contradice valores, bienes o intereses constitucionalmente tutelados, ni vulnera precepto legal alguno configurador de la autonomía universitaria, ni siendo el acuerdo claustral expresión de un derecho de libertad debe buscársele raíz o causa exógenos a la libre decisión claustral. La racionalidad del acuerdo, implícita en él pero comprensible sin esfuerzo, consiste en considerar que es más adecuado a la lógica de un Estado aconfesional un escudo universitario sin elementos de significado religioso que con ellos. Sin duda es posible discrepar lícitamente de tal decisión, pero lo que no resulta posible es calificarla de irracional, absurda o arbitraria, por lo que la interdicción de la arbitrariedad de los poderes públicos (art. 9.3. CE), entendida como garantía sustantiva e irreductible a cualquier otra, no ha sido vulnerada o desconocida en el presente caso".

El razonamiento se cierra, por ello, señalando: "Pues bien, dado que la capacidad del Claustro universitario para la elección de sus simbolos representativos entra de pleno en el contenido normal de la potestad autonormativa de la Universidad, y dada la inexistencia de predeterminación nomativa ni de contenido preceptivo algu- 
no respecto a los criterios que a tales efectos habrían de seguirse, resulta evidente el apoderamiento incondicionado o, si se prefiere, la plena libertad electiva del Claustro para adoptar, entre todas las posibles, la opción mayoritariamente considerada más conveniente; elección que, a falta de elementos objetivos y normativos que la sustentaran, se habría necesariamente de adoptar conforme a criterios de oportunidad o conveniencia libremente valorados y decididos por los claustrales".

De dicho razonamiento deben extraerse las pautas esenciales determinadoras de la competencia ejercida por el órgano intrauniversitario, a saber: que la Universidad goza de capacidad de autonormación en los términos que prevén las Leyes -especialmente la LRU-; que esa capacidad se materializa a través de reglamentos autónomos a los que aquellas sirven de parámetro controlador o límite de la legalidad de sus contenidos; que el Claustro universitario es el órgano competente -en este casopara realizar esa función autonormativa; que la concreta normación realizada forma parte de la potestad normativa atribuída a cada Universidad; y que la misma no vulnera ni contradice valores, bienes o intereses constitucionales, ni precepto legal alguno.

Sensu contrario, la decisión jurisprudencial se ha situado en este aspecto extramuros de un mero control de legalidad, puesto que apelando a la ausencia de causa jurídica o interés público fundamentador de la decisión claustral, se introduce o guía por criterios de oportunidad que le estan vedados o prohibidos. Así lo reconoce el Tribunal, cuando más tarde señala que a los jueces y Tribunales corresponde "la revisión jurisdiccional de los poderes que la LRU otorga o reconoce a las Universidades, de forma que ni padezca la legalidad ni la autonomía universitaria. De ahí que este control judicial, de una parte, deberá atenerse a la configuración legal de la autonomía universitaria sin imponer a ésta límites que no quiso establecer el legislador de la LRU, y, de otra, habrá de respetar el núcleo de la libertad de decisión, fruto de la autonomía, que en cada caso se considere más conveniente o adecuado a los intereses de la propia Unviersidad; pero lo que está vedado al órgano judicial es situar el control de legalidad en los confines de la oportunidad de la decisión libremente adoptada en ejercicio de la autonomía, y rebasarlos, como ha sucedido en el caso que nos ocupa".

Ello al margen -como hemos visto el TC desliza el argumento-, la adopción del acuerdo no queda huérfana de causa jurídica, ni por tanto ayuna de interés público, aunque en uno y otro caso, ello sea objeto de ponderación y valoración divergente en función de la perspectiva que se acoja.

La causa jurídica cabe apreciarla "en considerar que es más adecuado a la lógica de un Estado aconfesional un escudo universitario sin elementos de signo religioso que con ellos". Podrá o no compartirse esta causa, pero en cualquier caso no puede negarse que como tal es una causa razonable que tiene sentido y solidez, incluso constitucional.

El interés público, del mismo modo, puede constatarse razonando, como el TC hace: "Se considera que la nueva simbología identifica mejor a la institución representada o desempeña de manera más oportuna o conveniente la función integradora 
o representativa que todo símbolo comporta o, lisa y llanamente, satisface o responde mejor a las sensibilidades y preferencias de diversa índole de quienes con su voto contribuyeron a la aprobación de los nuevos elementos representativos de la Universidad".

Ciertamente en este punto el máximo intérprete constitucional utiliza con alternancia esas tres opciones, sin darle mayor importancia, por cuanto ya ha partido de la base de la innecesariedad de buscar causa jurídica o interés público justificativos, como hemos visto. Es por eso por lo que insiste en reiterar que "la plena libertad electiva del Claustro para la adopción del escudo universitario incluía la libertad de innovación o modificación del hasta entonces vigente, sin que el respeto o el mayor grado de respeto a la tradición y a la historia fuera el único criterio que válidamente pudieran tener en cuenta los claustrales al decidir, en legitimo ejercicio de su autonomía, el escudo de la Universidad valenciana. Las evidencias históricas y las razones heráldicas no bastan, sin más, para menoscabar el derecho fundamental de autonomía universitaria ni, por ello mismo, para sustituir los símbolos libre y voluntariamente decididos por el Claustro Constituyente por otros que, como los propuestos por la minoría disconforme, seguramente serían igual de lícitos y respetables, sólo que no han sido los mayoritariamente votados".

Completando su razonamiento, el TC sienta en el penúltimo párrafo de sus fundamentos jurídicos, la idea núclear del interés público (6), o más exactamente, la determinación de a quién corresponde fijar éste y sus límites. "En un Estado democrático de Derecho -nos dice- que proclama como valores superiores del ordenamiento la libertad y el pluralismo político, la vía natural de expresión de la idea y del contenido que la sociedad -en nuestro caso, la comunidad universitaria- tiene del interés público vigente en cada momento, cuando se trata de la adopción de Acuerdos que llevan consigo opciones de naturaleza primaria o prevalentemente política -como los adoptados por el Claustro Constituyente en representación de la comunidad universitaria y en ejercicio de su autonomía- lo constituye la voluntad mayoritaria de los órganos representativos, formada en debate público y a través de los procedimientos jurídicos establecidos, cuya observancia queda sujeta en todo caso al control de Jueces y Tribunales".

Así, pues, la determinación del interés público, cuando entran en juego supuestos de naturaleza primaria o prevalentemente política -y el caso planteado puede integrarse en ambos supuestos-, corresponde al órgano representativo -Claustro universitario, en el caso-, con los requisitos formales o jurídicos que impone la legalidad vigente. Estos últimos límitan la libertad de decisión de aquél y son revisables judicialmente en cumplimiento del estricto control de legalidad ( 7$)$.

Más alla de ese nivel no les está permitido el control a los Jueces y Tribunales, ya que tal proceder significaría sustituir la voluntad del órgano administrativo en aquéllos supuestos, por su conveniente u oportuna opinión. Como también les está vedado transmutar argumentos de esta última especie en argumentos jurídicos no previstos como tales. De ahi que con excelente criterio, la STC 130/1991 de 6 de Junio concluya sintéticamente diciendo "que los argumentos de diversa naturaleza (históricos, emocionales, heráldicos), pero todos ellos de oportunidad o convenien- 
cia, fueron aducidos y defendidos durante el proceso de formación de la voluntad claustral y no prosperaron ante la mayoría, que optó por cambiar los símbolos emblemáticos de la Universidad de Valencia. Lo que no es posible es convertir por vía judicial aquellos argumentos de oportunidad en impedimentos jurídicos para el legitimo ejercicio por aquel Claustro Constituyente del derecho fundamental de autonomía universitaria. En consecuencia procede declarar legítimo aquel acuerdo, que no vulneró ningún derecho fundamental ni contradice precepto legal alguno, y anular las Sentencias que lo anularon".

\section{REFLEXIONES FINALES.-}

La STC 130/1991 de 6 de Junio descansa sobre una argumentación jurídica consecuente con la doctrina constitucional sobre la autonomía universitaria, y posee, por ello, un fallo o resolución lógico y esperado.

Lo ilógico e inesperado radica en las dos sentencias (la de la AT de Valencia y la del TS) que han servido de soporte al amparo constitucional demandado, las cuales inexplicablemente, a nuestro entender, se han servido de argumentos de legalidad ordinaria escasamente fundamentados para enervar el derecho fundamental tutelado en el art. 27. 10 CE.

Esta circunstancia ha propiciado la severa censura del TC a las decisiones judiciales, el reconocimiento de la vulneración del derecho fundamental, y la consiguiente anulación de las sentencias de los Tribunales ordinarios de los que traía causa.

De otra parte, la misma circunstancia reseñada ha comportado que la STC a la que hemos prestado nuestra atención, discurra en su fundamentación jurídica por cauces ya conocidos y que por ello sea escasamente original e innovadora.

En efecto, como se ha podido comprobar, su posicionamiento descansa en la conceptuación, contenido y alcance de la autonomía universitaria, sentados en las precedentes resoluciones 26/1987 y 55/1989 antecitadas. Con esas premisas, el acuerdo discutido tal y como fue efectivamente adoptado era claro que encajaba de pleno en la disponibilidad autonormativa de la Universidad. Más aún, que las supuestas irregularidades procedimentales detectadas por los Tribunales habrían de ceder ante la prevalente materialización de aquel derecho, dado que su consideración no dejaba de ser supuesta, -esto es, no real-, en un caso (el de la pretendida infracción del art. 47.1.c. LPA), y en el otro (el de la pretendida arbitrariedad de los poderes públicos), al margen de la inexistencia misma de la arbitrariedad, la decisión del Claustro no era otra cosa que el ejercicio efectivo de la voluntad manifestada por este órgano de la autonomía universitaria, sin vulnerar preceptos legales ni derechos, bienes o intereses constitucionalmente protegidos.

Tal vez sea, no obstante, en este último extremo, en el único en el que la decisión comentada revela algún elemento de mayor interés o novedad. Esto sucede apurando con todas sus consecuencias el contenido que cabe atribuir a la autonomía universitaria, aunque la Sentencia, en todo caso, arranque de constatar la causa jurí- 
dica fundada en un interés público en el acuerdo del Claustro, discrepando, también aquí, de la determinación judicial.

De cualquier manera, las observaciones que obiter dicta realiza el TC sobre la configuración del interés público constituyen pautas de referencia importantes al respecto para el desarrollo futuro del contenido del derecho que aquí se discutía.

\section{NOTAS.-}

(1). En general, sobre la autonomía universitaria, veáse además de la jursprudencia constitucional contenida en las SSTC 26/1987 de 27 de Febrero, 55/1989 de 23 de Febrero y 106/1990 de 6 de Junio; básicamente las obras y monografías de: ALEGRE AVILA, J.M. En tomo al concepto de autonomía universitaria (A propósito de algunos caracteres del régimen universitario español. En especial, sus implicaciones funcionariales), en REDA, 51. 1986; FERNANDEZ RODRIGUEZ, T.R. La autonomía universitaria: ámbito y límites. Civitas. Madrid, 1982; GARCIA DE ENTERRIA, E. La autonomía universitaria, en RAP, 117. 1988; LEGUINA VILLA, J. y ORTEGA ALVAREZ, L. Algunas reflexiones sobre la autonomía universitaria, en REDA, 35. 1982; LEGUINA VILLA, J. La autonomía universitaria en la jurisprudencia del Tribunal Constitucional, en Libro Homenaje al Prof. E. García de Enterría. II. Madrid, 1991; LINDE PANIAGUA, E. La autonomía universitaria, en RAP, 84. 1977; LOPERENA ROTA, D. El marco de la autonomía universitaria tras la STC 26/1987 de 27 de Febrero, en RVAP, 21. 1988; LOPEZ JURADO ESCRIBANO, F. La autonomía de la Universidades como derecho fundamental: La construcción del Tribunal Constitucional. Civitas. Madrid, 1991; MARTIN-RETORTILLO BAQUER, L. Autonomía y autogobierno en la Universidad, en Publicaciones de la Universidad de Zaragoza, 1980; NIETO, A. Autonomía política y autonomía universitaria, en Rev. Dep. Derecho Político. UNED, 5. 1981; y SANCHEZ BLANCO, A. El derecho fundamental a la autonomía universitaria.

Con pretensiones más modestas y sobre aspectos específicos, veánse nuestros trabajos: Un órgano atípico y conflictivo: La Comisión de Reclamaciones del art. 43 de la RLU, y La aplicación de la autonomía universitaria para la constitución de Departamentos, ambos en REDA, 68. 1990.

(2). Un riguroso análisis crítico de la doctrina constitucional configurando la autonomía universitaria como derecho fundamental, realiza LOPEZ-JURADO ESCRIBANO, en ob.cit. pags. 79 y ss. LEGUINA VILLA en su trabajo antecitado, tras exponer la planteada contraposición entre las categorías jurídicas "derecho fundamental" y "garantía institucional", explicita las razones que impelieron al TC a pronunciarse por la primera de ellas, y los cuatro criterios que justificaron esta toma de posición.

Acerca de las diferencias entre esas dos categorías, vid. entre otros: BAÑO LEON, J.M. La distinción entre derecho fundamental y garantía institucional en la Constitución española, en REDC. 8, 1988; JIMENEZ BLANCO, A. Garantías institucionales y derechos fundamentales en la Constitución, en Libro homenaje al Prof. E. García de Enterría, cit.; LOPEZ JURADO ESCRIBANO, cit. págs. 81 y ss; y PAREJO ALFONSO, L. Garantía institucional y autonomía local. Madrid, 1981.

(3). Ob. cit. pág. 1203. 
(4). Vid. al respecto LOPEZ-JURADO ESCRIBANO, cit. págs. 92 y ss.

(5). Críticamente con la expresión "reglamentos autónomos" se muestra LOPEZ-JURADO ESCRIBANO, págs. 74 y ss., estimando más adecuado y clarificador referirse a este fenómeno de autonormación con el calificativo de "normas estatutariass". Sobre las diferencias entre uno y otro concepto, vid. además, JIMENEZ BLANCO, A. Manual de Derecho Administrativo, AA.VV. Barcelona, 1990, págs. 115 y ss.

(6). Respecto de la noción de interés público, veánse entre otros los trabajos de; SAINZ MORENO, F. Reducción de la discreccionalidad: el interés público como concepto jurídico, en REDA. 8. 1976 y Sobre el interés público y la legalidad administrativa. RAP, 82. 1977; y BERMEJO VERA, J. El "interés general" como parámetro de la jurisprudencia constitucional, en RVAP, 10, II, 1984.

(7). Sobre la relación, a propósito del interés público, entre Administración y Justicia, vid. MARTIN MATEO, R. Manual de Derecho Administrativo, 13 ed. Madrid, 1990, págs.79-80. 


\section{"UN PROCESO HISTORICO; MIGUEL HERNANDEZ"}

MIGUEL GUTIERREZ CARBONELL

Profesor Asociado Derecho Procesal

LECCION INAUGURAL

APERTURA DEL CUSO 1991-92 (UNED DE ELCHE)

("UNO DE LOS POSIBLES ENSAYOS SOBRE EL DERECHO REPRESIVO FRANQUISTA - 1936 - 1945")

SUMARIO - GUION DE LA LECCION

DEDICATORIA

I.- UNA JUSTIFICACION DIFICIL

II.- UNO DE LOS POSIBLES ENSAYOS SOBRE EL DERECHO REPRESIVO FRANQUISTA (1936 - 1945) - METODO DE TRABAJO - ESCEPTICISMO SOBRE LA UTILIDAD DE ESTOS ESTUDIOS.

III.- UNA SINTESIS DE LO PARTICULAR: A) "EL PROCEDIMIENTO SUMARISIMO DE URGENCIA № 21001, CONTRA MIGUEL HERNANDEZ GILABERT" Y B) "EL EXPEDIENTE PENAL DEL REFORMATORIO DE ADULTOS DE ALICANTE".

IV.- LO GENERAL; APRETADA SINTESIS SOBRE EL DERECHO REPRESOR FRANQUISTA (1936 - 45):

1. LEGALIDAD - LEGITIMIDAD

2. EL DERECHO REPRESIVO APLICADO

- EL BANDO DE GUERRA DE 28 DE JULIO DE 1936.

- EL CODIGO DE JUSTICIA MILITAR DE 27 DE SEPTIEMBRE DE 1890.

- LA LEY DE RESPONSABILIDADES POLITICAS DE 9 DE FEBRERO DE 1939.

3. UN DELITO DE REBELION INVERTIDO "SUI GENERIS"

4. LA FALTA DE GARANTIAS JURISDICCIONALES

5. EL PROCEDIMIENTO SUMARISIMO; MAQUINA VULNERADORA DE GARANTIAS JURISDICCIONALES

6. LA LEY DE RESPONSABILIDADES POLITICAS DE 9 DE FEBRERO DE 1939

V.- SINOPSIS CRITICA DE LA SENTENCIA CONDENATORIA DE MIGUEL HERNANDEZ

VI.- Y... PUNTO FINAL 
EXCMO. SR., ILTMOS. SRES., SRES., SRAS., COMPAÑEROS, MIS QURIDOS ALUMNOS;

Permitidme que mis primeras palabras sean de recuerdo para los forzados protagonistas de estos procesos:

\section{DEDICATORIA}

En memoria del sacrificio y valentía de todos aquellos que fueron objetos, que no sujetos, de los juicios de la cruenta represión franquista; a aquellos que sucumbieron y a los que lograron sobrevivir.

Con palabras de ALBERTI, digo:

"Juan Panadero en la guerra

fue tan sólo Juan soldado,

un Juan soldado cualquiera,

...lo mismo que Juan o Antonio,

SANGRE CALIENTE DEL PUEBLO".

Paz y salud para los injustamente perseguidos.

\section{I.- UNA JUSTIFICACION DIFICIL}

He sido graciosamente invitado por la Dirección del Centro para dictar la lección inaugural del presente Curso.

Aunque inicialmente me resistí a ello, contrariando el propio impulso de mis afectos, hay dos motivos que me han llevado a reconsiderar mi primitiva decisión "irrevocable"; tan irrevocable como, afortunadamente, lo son todas en la vida.

Bien es verdad que no estoy muy seguro de la prioridad entre tales razones.

Una: Mi larga y estrecha vinculación, como Profesor-Tutor de Procesal, a la UNED de ELCHE, a su Dirección y a los compañeros (Profesores y alumnos). He pasado aquí ratos de grato recuerdo. Pienso que una de las formas más eficaces de aprender es tratando de enseñar. $Y$ he aprendido bastante de mis alumnos.

La otra: El tema que sagazmente, ante mi débil resistencia, me propueso vuestro Director: "El proceso de Miguel Hernández".

Para mí es un tema apasionante y sugerente. Es un compromiso al que intelectual y emocionalmente se siento obligado, no me importa decir, haciéndome más vulnerable, que "hasta mancharme".

El proceso del poeta, con toda la carga de su valor de símbolo y hasta de mito, como punto de partida para un estudio objetivo, científico, de la legalidad de la represión franquista de 1936-45.

$Y$ este es reto intelectual y moral al que uno no debe, ni quiere, sustraerse.

Pero me apresuro a anticipar, para vuestro descanso, que yo entiendo esta actividad académica entre lúcida y lúdica.

Por eso, como explicaré, intitulo a esta lección, "ENSAYO", y me sujetaré a los 
límites razonables de la cortesía y del uso académico y desde aquí prometo exoneraros de la pesada carga del aparato bibliográfico y de sesudas citas eruditas.

\section{II.- UNO DE LOS POSIBLES ENSAYOS SOBRE EL DERECHO REPRESI- VO FRANQUISTA (1936 - 1945) - METODO DE TRABAJO - ESCEPTI- CISMO SOBRE LA UTILIDAD DE ESTOS ESTUDIOS.}

La elección del género de exposición no es gratuita, ni fruto de mi natural modestia, es premeditada.

Un ensayo, en la aceptación literaria del género.

Decía un filósofo, contemporáneo y clásico, que el "ensayo es la ciencia, menos la prueba explícita", "dejar las comprobaciones meramente indicadas en elipse", para que si alguien las precisa "pueda encontrarlas"; pero de tal modo que nunca las acumulaciones de citas "estorben la expansión de íntimo calor con que los penamientos fueron pensados".

Yo entiendo el ensayo como un esbozo, anticipador de otros trabajos mayores, posiblemente inconclusos y frustrados.

El ensayo es el banco de pruebas en que el trabajador intelectual trata de corregir y perfeccionar sus propias ideas.

Pero me niego a admitir que todos los ensayos sean frutos inmaduros, carentes de sustancia, aunque éste, bien pudiera serlo.

El método de trabajo utilizado es el inductivo; partiendo de lo particular (el estudio del proceso y expediente carcelario de Miguel Hernández, además de otras sentencias dictadas en procesos similares, y de la legislación de la época aplicable), alcanzar lo general, las conlusiones sobre la valoración jurídica del sistema penal, sancionador y procesal franquista de la etapa acotada.

Podría refutarse la validez científica de los resulados, ya que se aplica las inducción basándola en "enumeraciones incompletas", es decir numericamente insuficientes.

Tal objeción no es cierta; bastaría con un análisis del derecho positivo represor de la época para sacar conclusiones técnicamente correctas.

Pero para establecer una valoración es necesario fijar unos parámetros comparativos; entre un modelo de proceso debido (justo) y el que se aplicó.

Hay que admitir aquella realidad histórica; la Guerra finalizada (1939), los vencedores impartiendo su justicia.

Medir aquella etapa con la actual situación normalizada, democracia; aplicar los parámetros del modelo constitucional del "proceso debido" a aquellos, no sería lícito, ni cientificamente honesto.

Pero comparar tal legislación y la práctica de la justicia militar franquista, con la etapa inmediata anterior de la $2^{\mathbf{a}}$ República vencida; analizar las contradicciones y vulneraciones de la legislación represora de los vencedores, con los principios bási- 
cos, elementales, admitidos como conquista de la civilización de la época, si es lícito, técnicamente correcto y moralmente obligado.

Porque debe tenerse en cuenta que esa justicia se impartía finalizada ya la guerra civil, con una legalidad formal establecida y aplicándola todo un aparato orgáinico institucionalizado (la "Jurisdicción Militar").

No hablamos aquí de la represión en plena guerra, por grupos incontrolados; ni nos vamos a referir a los que, no con mucha precisión, se ha denominado el "terror rojo" y el "terror blanco". Tampoco nos ocuparemos de la justicia de los Tribunales populares que se crearon y actuaron en la zona republicana, objeto de un reciente y valioso estudio histórico.

El terreno de nuestra investigación ha sido conscientemente delimitado; el proceso de Miguel Hernández como motivo, sí se quiere como pretexto, para ensayar un estudio de la represión judicial franquista de 1936 - 1945. El resto de horrores, represiones e injusticias de uno y otro lado, queda a extramuros de nuestro estudio, aunque sea materia colindante.

Y eso es lo que el estudioso imparcial si tal abstracción cabe, debe preguntarse. ¿Si aquella legalidad formal estaba legitimada; si aquellas conductas tipificadas a las que la Ley llamaba rebelión, realmente lo eran; si las penas fijadas eran proporcionadas a los delitos, dando por bueno que lo fueran; si los procesos tenían las mínimas garantías jurisdiccionales: de independencia de los juzgadores, de admisión del ejercicio de derecho de defensa, de posibilidad de proposición de pruebas, de acceso al derecho de recursos...?. Todas esas garantías, fruto de una larga y costosa evolución de la civilización, conquistadas e incorporadas al patrimonio de ese mismo pueblo que ahora, desarmado y derrotado, iba a ser juzgado por sus vencedores, sin esperanza de que se las aplicasen.

Tal vez algunos piensen que se trata de una obviedad. En ocasiones lo obio es lo más dificil de probar, pero en todo caso, merece ser analizado.

Alcanzado este punto del discurso de nuestro pensamiento, cabe preguntarse sobre la utilidad de estos trabajos retrospectivos, para algunos entre nostálgicos, inoportunos, vindicativos y tendenciosamente parciales.

Pensamos, como alguien ya ha dicho, que nuestra normalidad democrática no debe adormecer la conciencia del pasado y que es un saludable ejercicio la recuperación de la memoria histórica.

Tanto más saludable cuanto las secuelas de la aplicación de ese derecho represor franquista -número de presos políticos, de fallecidos en las cárceles y de ejecutados- ha marcado cualitativa y cuantitativamente nuestra história.

No terciaremos, aquí y ahora, en la macabra dispunta de los muertos de uno y otro bando.

Pero sí, como botones de muestra, significativos, por haberse dado como cifras oficiales, señalamos éstas:

Población Reclusa.- Presos políticos, el 7 de Enero de 1940, hay 270.719 y el 10 de Abril de 1943, aún hay 92.477 reclusos políticos (Datos que suministra el 
Director General de Prisiones, Angel B. Sanz, en su libro de "De re penitenciaria" publicado en 1943, con Prólogo del Ministro de Justicia Eduardo Aunós).

Muertos.- Incluidos los presos políticos ejecutados procesados y los fallecidos en la Cárcel. Desde Abril de 1939 al 30 de Junio de 1944, son 192684 personas. (Cifra oficial facilitada por el Ministerio de Justicia de aquella época; citas tomadas de Marino Barbero en "Política y D. Penal en España").

Cierto que la comprensión del pasado, no es salvaconducto para un futuro sin los pretéritos yerros. Pero puede el recuerdo de áquel horror actuar positivamente, en función profiláctica mas que terapéutica de nuestra sociedad.

Y ese es, y no otro, el móvil ético impulsor de nuestro discurso.

Asumiendo el sentimiento del poeta, podríamos nosotros decir, también:

"Sentado sobre los muertos,

...empuño rabiosamente

la mano del corazón

y el alma que lo mantiene".

Como un grito esperanzador, aunque rehogado en el escepticismo, para que la cordura evite, en el futuro, tales desmanes.

Y entrando ya, en la médula de nuestro trabajo, lo dividiremos en estas dos partes:

DE LO PARTICULAR: (El Proceso de Miguel Hernández)

DE LO GENERAL: (Análisis del derecho represor franquista).

\section{III.- UNA SINTESIS DE LO PARTICULAR: "EL PROCEDIMIENTO SUMARISIMO DE URGENCIA № 21001, CONTRA MIGUEL GER- NANDEZ GILABERT" Y "EL EXPEDIENTE PENAL (CARCELARIO) DEL REFORMATORIO DE ADULTOS DE ALICANTE" DE DICHO PENADO.}

Parece oportuno, referirse brevemente, a la pequeña historia sobre la búsqueda y el hallazgo de estos dos documentos fundamentales, hasta hace poco tiempo inéditos y no localizados.

Fue la "Asociación Estudios Miguel Hernández", de Alicante, la pionera, de la que lanzó la idea de su búsqueda.

El Ayuntamiento de Alicante, nombró una Comisión Técnica en Diciembre de 1989 , compuesta por cuatro miembros, con tal finalidad.

Sobre finales de Marzo y principios de Abril de 1990, miembros de esta Comisión, tras diversas gestiones, localizaron el expediente carcelario en el Centro Penitenciario de Fontcalent (Alicante) y el proceso en el Tribunal Militar № 1 de Madrid (aunque se encontraba en las dependencias del Cuartel de Campamento, de donde solicitaron su traslado). Fué necesario realizar varias visitas y gestiones; en Mayo y Junio de 1990, la Comisión solicitó oficialmente y obtuvo el texto íntegro, 
fotocopiado, del expediente y del proceso; también se le autorizó para fotografiar, con diapositivas, todo el proceso. Disponiéndose en la actualidad, de todo este valioso material.

El 30 de Septiembre de 1990 el periódico INFORMACION, por primera vez, que sepamos, anunció el hallazgo por la Comisión de estos dos documentos y publicó un extenso cuadernillo, con artículos de los componentes de la misma, y reproducciones parciales de los textos originales.

Recientemente (la data de impresión es de Noviembre de 1990) se ha publicado un libro sobre el proceso de Miguel Hernández.

La Comisión, por diversas causas, no ha ultimado su inicial propósito de publicar sus estudios, histórico, literario y jurídico sobre tales documentos.

Yo, como miembro de tal Comisión, me baso en los materiales obtenidos para efectuar el presente análisis. Me parece obligado decir lo que precede, porque es de bienacidos ser agradecidos.

Hagamos primero una apretada síntesis, comentada de:

\section{A) EL PROCEDIMIENTO SUMARISIMO DE URGENCIA № 21001 CON- TRA MIGUEL HERNANDEZ GILABERT.}

Consta de unas 75 páginas, foliadas solamente 40; en aceptable estado de conservación, algunos fragmentos dificilmente legibles. Reseñaremos lo fundamental.

Se inicia con un atestado policial de los Agentes del Cuerpo de Investigación y Vigilancia de Rosal de la Fontera (Huelva). Motivo: la detención, 4 de Mayo de 1939, de Hernández en Moura, por la policía portugesa, por paso ilegal de la frontera.

Hay una extensa declaración del detenido, de la que entresacamos; "Estrechado a preguntas manifiesta que García Lorca era uno de los hombres de gran espitirualidad de España...; advirtiendo a los Agentes que suscriben que tengan cuidado no se repita el caso de García Lorca que fue ejecutado rápidamente...".

Niega su afiliación a partidos políticos. al movilizar su quinta se incorporó a un Batallón de Zapadores, en Madrid. Reconoce que ha escrito versos para varios periódicos ("Al Ataque", "El Mono Azúl"). En Junio de 1938 pasó a la Sexta División, siendo destinado a la Escuela de Oficiales de Albalat de Sorell (Valencia), trabajando en la confección de murales y publicando poesías en algunas revistas ("Comisario", "Ayuda", "Occidente", "Nueva Cultura"...) "Cumpliendo la consigna dada, recomendando la resistencia en los frentes a las Fuerzas Nacionales". Todas estas publicaciones suyas están recopiladas dice, en el libro que se editó en Valencia 1937, "Viento del Pueblo".

Los Agentes redactores del atestado, con motivo de su detención, concluyen el mismo con la siguiente diligencia;

"Estrechado a preguntas ha incurrido en muchas contradicciones: estaba muy nervioso y excitado... 
Por tanto, es de suponer que este individuo haya sido en la que fué zona roja por lo menos uno de los muchos intelectualoides que exaltadamente han llevado a las masas a cometer toda clase de desafueros si es que él mismo no se ha entregado a ello. De todo lo cual, como Secretario habilitado, certifico".

El 9 de Mayo es trasladado a la Prisión de Madrid. El Auditor de Guerra del Ejército de Ocupación remite las actuaciones al Juez Militar Permanente $\mathbf{n}^{\circ} 5$ (Rodicio Arias). Este Juzgado se inhibe en favor del Especial de Prensa (Martinez Gargallo), por tratarse de un periodista.

Dicho Juzgado (Especial de Prensa) incia la instrucción. Por Providencia de 4 de Julio de 1939 "se hace cargo del sumario" y en esa misma resolución dice: "en atención a los cargos que se desprenden contra el encartado MIGUEL HERNANDEZ GILABERT, se le declara en situación de procesado a las resultas de esta causa que se tramitará como sumarísima de urgencia, a cuyo objeto se le recibirá seguidamente declaración indagatoria". (F/ 10 de la actuaciones).

Hasta ese momento Hernández sólamente había prestado una declaración policial, ninguna judicial, ni se habían aportado al sumario documentos en que fundamentar tal resolución.

El procesamiento, como después se comentará, no está motivado, no se consignan los hechos imputados, ni se establece ningún fundamento de derecho determinante del mismo. Se trata de una simple providencia de trámite, pese a sus trascendentes consecuencias.

Presta el Procesado, una larga declaración indagatoria (la primera ante juez Militar), de la que entresacamos literalmente (F/11).

"Que no pertenece a ningún partído político, ni organización sindical, ni antes ni después del Movimiento, pero que reconoce sus ideales antifascistas y revolucionarios, no estando identificado con la Causa Nacional, creyendo que el Movimiento Nacional no puede hacer feliz a España.

... El Albalat de Sorelles se confeccionó un mural, con fotos y alegorías antifascistas, del cual es uno de los autores el dicente.

Su libro "Viento del Pueblo" ...es una compilación de toda su labor como escritor antifascista y al servicio de la "causa del pueblo"...conteniendo exaltaciones, dice el dicente, de los rasgos "nobles" de la causa marxista.

Escribía solamente por identificación con la causa popular" -afirma el declarante.

Preguntado... contesta que reconocía esta labor delictiva en contra de la invasión".

Sobrecoge la entereza, el temple del interrogado. En una situación de tan desolado amparo, dificilmente podemos valorar hoy la carga de dignidad y coraje que entraña este reconocimiento de los propios principios.

La lectura de estas envejecidas páginas nos produce desazón y desaliento; nos invade una sensación de pretérita impotencia, de inutilidad ante lo que ya se canta como irremediable; no se sabe qué hacer, ni qué decir... 
Y así sentimos una vez más, pero ahora más vitalmente, la recia voz de otro poeta:

"Voluntario de España, miliciano,

de huesos fidedignos, cuando marcha a morir tu corazón,

...no sé verdaderamente qué hacer, dónde ponerme..."

$\mathrm{Si}$, Miguel fue eso: un hombre, un poeta, de huesos fidedignos; fiel a su pueblo, fiel a sus ideas, fiel a sus sentimientos. No es poco.

Durante la instrucción del Sumario se practicaron muy pocas diligencias. No intervino -legalmente no era posible- ningún Abogado defensor. Solamente en base a las escasas diligencias practicadas, tomándolas como pruebas, basó el Fiscal su acusación y las mimas fueron declaradas hechos probados por el consejo de guerra para fundamentar su fallo condenatorio.

Las diligencias practicadas se limitan a la aportación de los artículos publicados por el procesado, durante la guerra en los siguientes periódicos: "La Voz", "El Sol" y "El Mono Azul"; uno de éstos escritos se refiere a la ocupación del Santuario de Santa María de la Cabeza. Se incorpora también a las actuaciones una copia de la famosa carta "A los intelectuales antifascistas de todo el mundo", firmada entre otros por Miguel.

Hay un informe del a la sazón, Alcalde de Orihuela en el que se le califica de persona: ..."francamente de izquierdas, más aún marxista, incapaz por temperamento de acción directa en ningún aspecto, pero si de activísima propaganda comunistóide. Se sabe que durante la Revolución ha publicado numeroso trabajos en toda clase de periódicos... estuvo agregado el Estado Mayor de la Brigada del Campesino... Se le conocía por "el Pastor Poeta" y ultimamente por "El Poeta de la Revolución". Dios que salvó a España, guarde a Vd. muchos años. El Alcalde de Orihuela". (F/13).

Existe también un informe de que "su conducta ha sido en todo momento correcta", emitido por la Editorial Espasa -Calpe-, en donde trabajó para Jose María Cossio.

Se le recibe ampliación de la indagatoria ( $\mathrm{F} / 15)$ encaminada a averiguar si fue Comisario Político de la Brigada de choque de "El Campesino", ya que en el prólogo de su libro "Teatro en la Guerra", que se une "en cuerda floja a las actuaciones" (por cierto desaparecido cuando manejamos los autos originales), así se hace constar.

Interrogado, en esta ampliación, el procesado manifiesta:

"Que no fué Comisario Político...Se le exhibe y lee lo que consta en tal libro que sí lo afirma- y dice: Que efectivamente no conoció el contenido de esa introducción hasta después de publicado el dibro y cree se debió hacer por la Editorial a fines de publicidad... No creyó necesario, ni opotuno hacer una rectificación... Que sí asistió a las operaciones del Santuario Virgen de la Cabeza con el Comandante Carlos, pero fue en calidad de agente de propaganda, escribiendo un artículo en el periódico "Ayuda" de Valencia, en el que reflejaba los operaciones... y que a su juicio fue bueno. 
...A petición del Instructor designa personas solventes que pueden avalar sus manifestaciones (y conducta)..."

Figura que carece de antecedentes penales. Se hace referencia una ficha de antecedentes policiales $(\mathrm{F} / 19)$ "suministrados por personas y organismos de absoluta solvencia"; que no se citan, en la que se afirma: "El Miguel Hernández vivió la guerra como agitador propagandista, estando siempre en íntimo contacto con el Comisario de propaganda de quien era uno de los elementos más activos. Se le supone de ideas comunistas...".

Y no hay más actos de investigación durante la instrucción que los reseñados.

Así, sin más, el Juez Instructor, del Juzgado Especial de Prensa, acuerda el 18 de Septiembre de 1939 en su "AUTO RESUMEN" (F/25):

Que se remitan las actuaciones "al Sr. Presidente del Consejo de Guerra Permanente, tenidas en cuenta las pruebas aportadas, estimándose que el hecho perseguido se encuentra sancionado en el Bando de Guerra y en su virtud ratifica el procesamiento de MIGUEL HERNANDEZ GILABERT por estimarlo plenamente acreditado...; existiendo además indicios muy racionales de haber sido Comisario Político de una Brigada de Choque".

El Fiscal-Jefe del Ejército de Ocupación -Ramón de Orbe- (así consta literalmente) en 28 de Septiembre de 1939, con los únicos elementos de cargo reseñados, califica los hechos de delito de adhesión a la rebelión militar (art. $238-2^{\circ}$ del C.J.M.) con las agravantes del perversidad y trascendencia de los hechos (art. 173 del mismo Código) y solicita la pena de muerte y la responsabilidad civil sin determinación de cuantía.

Se señala día (el 7 de Octubre de 1939) para la vista del Consejo de Guerra y se ordena el traslado del preso. El Director de la Prisión de Torrijos participa que el 15 de Septiembre de 1939, fué puesto en libertad por mandamiento del Director General de Seguridad.

Se ha de suspender la celebración de la vista de dicho Consejo de Guerra, ante la incomparecencia del acusado y se acuerda, por unanimidad la devolución de la causa al Auditor de Guerra para que "si lo estima procedente acuerde la apertura de procedimiento en esclarecimiento de los actos referidos". Estos hechos tienen por objeto averiguar cómo y por qué fue puesto en libertad ya que "tratándose de una persona destacadísima por su intervención en la revolución marxista notoriamente conocido, y al no habese explicado suficientemente el hecho de que un detenido a disposición judicial sea liberado por simple mandato de la Dirección de Seguridad, lo cual por otra parte no aparece legítimamente acreditado..." (F/27).

Dicho Auditor devuelve la causa al Juez - Instructor, de la misma para que se investiguen tales extremos y se ordene la "captura e ingreso de dicho sujeto en la prisión correspondiente, a resultas del Sumario...".

El Juez Instructor cumplimenta lo ordenado.

La Dirección General de Seguridad contesta con un extenso e interesante oficio justificando la excarcelación ordenada por el Gobernador Civil de Madrid, al creer 
que se trataba de un detenido gubernativo, sin responsabilidades penales y teniendo en cuenta los buenos informes recibidos sobre el mismo ya que el "interfecto es una persona de moral intachable... de orden e inofensiva" y "toda vez que en su expediente no había nada desfaborable concretamente como no fuera el haber sido escritor de izquierdas que quedaba en parte desvirtuada la mala impresión que pudiera producir su ideología política con el informe favorable emitido por el Sr. Cossio..." (firma iligible del Dtor. Gral de Seguridad - F/31 a 33).

Pese a ello se ordena por esa propia Derección Gral. la busca, detención, e ingreso en prisión, a disposición del Juzgado Instructor, del precesado.

Se le detiene en Orihuela (al parecer el 9 de Octubre de 1939) y es trasladado a la Prisión de Madrid.

E1 5 de Enero de 1940, el Instructor reproduce el Auto Resumen, copia del anterior, y eleva las actuaciones al Consejo de Guerra. El 13 de Enero el Fiscal (actuando por delegación, Leopoldo Huidobnno), dá por reproducido el anterior escrito acusatorio.

El día 18 de Enero de 1940, se celebra la vista del Consejo de Guerra. Los miembros del Tribunal son: Presidente, Comandante, Pablo Alfaro; Vocales; Capitán Francisco Pérez Muñoz, Capitán Ignacio Díaz Aguilar y Alferez Miguel Caballer Celis; Vocal Ponente; Capitán Vidal Morales.

Figura en las actuaciones una formularia acta del juicio oral; en ella no constan los nombres del Fiscal, ni del defensor. Paradógicamente, la defensa también le acusa, se limita a solicitar que se le rebaje la pena de muerte que pide el Fiscal, en un grado, o sea que se le impongan treinta años de reclusión.

El mismo día, el Consejo de Guerra Permanente dicta Sentencia.

"Resultando probado y así se declara. Que el procesado MIGUEL HERNANDEZ GILABERT, de antecedentes izquierdistas se incorporó voluntariamente en los primeros días del Alzamiento Nacional al $5^{\circ}$ Regimiento de Milicias pasando

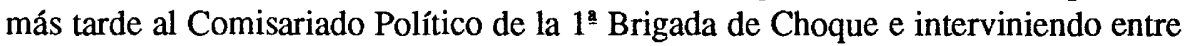
otros hechos en la acción contra el Santuario de Santa María de la Cabeza. Dedicado a actividades literarias era miembro activo de la Alianza de intelectuales antifascistas, habiendo publicado numerosas poesias y crónicas, y folletos, de propaganda revolucionaria y de excitación contra las personas de orden y contra el Movimiento Nacional, haciéndose pasar por el "Poeta de la Revolución".

Se estima que estos hechos probados son constitutivos de un delito de adhesión a la rebelión, del pfo. $2^{\circ}$ del art. 238 del C.J.M. y en uso de las facultades de los arts. 172 y 173 de dicho Código "se estima justo imponer la pena en su máxima extensión, se le condena a pena de muerte y en cuanto a responsabilidades civiles se estará a la Ley de 9 de Febrero de 1939".

Contra tal sentencia no cabe recurso alguno.

El 30 de Enero de tal año, siento trámite preceptivo, el Auditor de Guerra del Ejército de Ocupación, considera que "el procedimiento aparece tramitado con arreglo a derecho, sin que se adviertan defectos ni omisiones que afecten a su validez... 
que la prueba ha sido apreciada con un criterio racional y que es acertada la calificación legal de los hechos...; por todo ello ACUERDA: Aprobar la anterior Sentencia que declara firme y ejecutoria. Quedará en suspenso la ejecución del condenado hasta tanto se reciba el enterado de S.E. el Jefe del Estado".

El 25 de Junio de 1940, (SEIS MESES después, toda una espera de agónica incertidumbre) Su Excelencia -copio literalmente- "Se digna conmutar la pena impuesta por la inferior en grado"; es decir, treinta años. Y estos son los hechos y datos, más significativos del proceso.

\section{B) EL EXPEDIENTE PENAL DEL REFORMATORIO DE ADULTOS DE ALICANTE DE DICHO PENADO.}

Que sepamos se trata de un documento, hasta ahora, inédito que se conserva en los Archivos del Centro Penitenciario de Fontcalent (Alicante).

Consta de unas cuarenta y dos páginas no foliadas totalmente. Su estado de conservación es bueno. Se reflejan en este expediente las "vicisitudes penales y penitenciarias" del condenado, en ese Reformatorio (no en otros, al parecer estuvo en doce, en unos de tránsito y en otros con alguna duración).

Ingresa en el mismo el 29 de Junio de 1941, procedente del de Ocaña. Fallece en el Reformatorio de Alicante, el 28 de Marzo de 1942.

Figuran en este expediente documentos de carácter penal penitenciario y médico. Entre las frías líneas burocráticas se trasluce la desolación e incuria de aquella vida carcelaria que era un lenta agonía.

Nos referiremos a los documentos más significativos o curiosos. Hubiera cumplido su condena el 3 de Mayo de 1969. Ya fallecido, se la aplica, paradojas de la Administración, en 1944, una reducción de la pena a 20 años.

Existe una carta del Obispado de Orihuela interesándose por el preso, para que pueda asistirle un sacerdote. Figuran las autorizaciones de visitas de su esposa, en cuatro ocasiones, familiares y médico (Dr. Barbero, por afección pulmonar).

Su estado se agrava y el director de la Prisión solicita su traslado a un establecimiento adecuado. La autorización de la Dirección General de Prisiones, para ser trasladado a un Sanatorio Penitenciario de Madrid, se concede siete días antes de su muerte.

Fallece el 28 de Marzo de 1942, a las 5'30 horas, en la enfermería; estaban de imaginaria, Vicente Beneyto Luna y Blas Parreño Morell.

El Dr. José-María Pérez Miralles certifica su muerte por fimia pulmonar y dice; "El cadáver quedó con los ojos abiertos, debido a la imposibilidad de cerrárselos por medios naturales. ...Padecía un síndrome típico de hipertiroidismo, con sus faces de terror, con triada de fijeza, insistencia y esplendor en la mirada..., síntomas psíquicos puestos de manifiesto en su producción literaria... -viveza mental y emotividad exagerada-".

Diríamos que el certificante abandona la prosa oficial y expresa, hasta literariamente, su respeto y admiración por el fallecido. 


\section{IV.- LO GENERAL: UNA APRETADA SINTESIS SOBRE EL DERECHO REPRESOR FRANQUISTA (1936-1945).}

\section{LEGALIDAD - LEGITIMIDAD.}

Pasaremos por alto el problema filosófico-jurídico de la legalidad-legitimidad. "Todo derecho intenta justificarse (legitimarse) desde el poder que lo ha creado... y el individuo requiere y exige en mayor o menor grado, una justificación para la obediencia". (E. Díaz).

La esencia de la legitimidad es la trasformanción de la obediencia en adhesión. Cierto que la legitimidad sólo se realiza como aspiración.

"Un Estado será más o menos legítimo en la medida en que realice el valor de un consenso manifestado libremente por parte de una comunidad de hombres autónomos y conscientes (L. Levi-Bobbio).

En 1964 se publicó en este país oficialmente la "Réplica a un informe de la Comisión Internacional de Juristas", titulado "España Estado de Derecho".

Era un esfuerzo, casi patético, para tratar de demostrar la legitimidad jurídica del Nuevo estado Español, por su origen y por el ejercicio de su poder así como la ilegitimidad de los gobiernos del Frente Popular.

No es exajerado decir que las normas represoras que ocupan nuestro estudio eran legales, derecho establecido, aunque en ocasiones, incluso de dudosa legalidad formal, pero carecían de legitimidad.

2. EL DERECHO REPRESOR APLICADO: EL BANDO DE DECLARACION DEL ESTADO DE GUERRA DE 28 DE JULIO DE 1936; EL CODIGO DE JUSTICIA MILITAR DE 27 DE SEPTIEMBRE DE 1890 Y LA LEY DE RESPONSABILIDADES POLITICAS DE 9 DE FEBRERO DE 1939.

El arsenal de normas represoras del franquismo (penales, procesales, administrativas...) fue ingente. Gran importancia y aplicación tuvo, también, la Ley de Represión de la Masoneria y Comunismo de 1 de Marzo de 1940 y muchas otras (Ley de Seguridad del Estado, de 1939 y $1940 . .$. etc).

Aquí nos vamos a ocupar, únicamente en la parte que afecta a nuestro estudio, de las tres normas indicadas pues son las que se aplicaron en nuestro proceso, aunque también a la mayoría de los restantes (si exceptuamos, los masones, comunistas o "similares", como castizamente decía la propia Ley de 1940).

El Bando de Guerra de 1936 justifica su publicación del siguiente modo:

"Las circunstancias por las que atraviesa España exigen a todo ciudadano el cumplimiento estricto de las leyes, y por si alguno, cegado por un sectarismo incomprensible cometiese actos u omisiones que causen perjuicio a los fines que persigue este Movimiento Redentor de nuestra Patria, esta Junta de Defensa Nacional... DECLARA: 
- Hacer extensivo el estado de guerra a todo el territorio nacional, ya se había decretado en algunas Provincias.

- Serán juzgados por el procedimiento sumarísimo la larga lista de delitos que enumera, entre ellos la rebelión y sus modalidades accesorias.

- Se amplia notablemente el tipo de la rebelión. Lo son también: los que propaguen noticias falsas o tendenciosas con el fin de quebrantar el prestigio de las fuerzas militares o de los elementos cooperadores; los poseedores de armas; los que celebren cualquier reunión o manifestación sin permiso de la autoridad; los que coartasen la libertad de contratación... etc. (art. $6^{\circ}$ ).

- Sólo la propia Autoridad Militar podrá dejar de conocer, por su menor entidad, de una causa y remitirla a la ordinaria.

El Bando de Guerra, sin entrar en el fondo del mismo, plantea tres cuestiones formales que afectan a su validez y que han sido puestas de manifiesto por algunos autores.

Se dictó con arreglo a la legislación vigente a la sazón, la Ley de Orden Público de 28 de Julio de 1933. Prescindimos por su obviedad, de que no eran las autoridades competentes las que lo declararon (Arts. 48 y siguientes de la citada Ley).

Pero los bandos de Guerra exigían la norma de intimación, de la que carecía, totalemente, el referido.

"En dichos Bandos se INTIMARA a los rebeldes o sediciosos y perturbadores que depongan toda actitud hostíl y presten obediencia a la autoridad legítima" (art. 53 L.O.P.).

Se comprende lo difícil que resultaría, para los redactores del Bando insertar tal claúsula, dada la inversión de papeles existentes (rebeldes-Gobierno legítimo).

De acuerdo con la legislación imperante en la declaración de Estado de Guerra, la Autoridad Militar no podía, mediante Bandos, crear, ni ampliar los tipos delictivos, ni fijar penas distintas, ni agravar las preexistentes, lo único que legalmente podía declarar era la atribución del conocimiento de determinados delitos, ya existentes, a la Jurisdicción Militar (Art. 95 C.E.; art. 61 L.O.P.).

Otra cuestión que planteaba dicho bando era el de su vigencia temporal, generando una gran inseguridad en este fundamental extremo. Consultados varios comentaristas, hemos encontrado alguna cita que lo estima vigente en Julio de 1947; hay sentencias de 1946 en que se aplicó el mismo.

Somos conscientes de la escasa utilidad, a estas alturas, de los precedentes razonamientos de tipo formalista; pero tampoco es bueno su total olvido.

Otra normativa básica que se utilizó fué el Codigo de Justicia Militar de 27 de Septiembre de 1890 , restablecido "en todo su vigor con la redacción que tenía antes del 14 de Abril de 1931" por Ley de 12 de Julio de 1940.

La legislación republicana estableció importantes modificaciones en el C.J.M. de 1890. Limitó la competencia de la jurisdicción militar a los delitos estrictamente militares, suprimiendo la atribución de competencia por razón de la persona y del 
lugar. Estas y otras sustanciales mejoras jueron dejadas sin efecto por la citada Ley de 1940.

Se justificaba así en esta Ley la concepción del Nuevo Estado;

"...se impone la fórmula tradicional en nuestro Ejército de que el ejercicio de la Jurisdicción esté unido al mando militar..."

Y en el articulado de esta Ley de 12 de Julio de 1940 se declaraba:

- Todos los delitos derivados del Movimiento Nacional, aunque no se tratase de delito flagrante, ni les corresponda pena de muerte o perpetua, se tramitarán por el procedimiento sumarísimo.

- El cargo de defensor siempre será desempeñado por militar, con categoría de Oficial, como mínimo.

De la Ley de Responsabilidades Políticas de 1939, de menor incidencia en nuestro caso concreto, para no romper el hilo expositivo haremos una sumaria referencia al final.

\section{UN DELITO DE REBELIÓN MILITAR INVERTIDO, "SUI GENERIS".}

Los preceptos penales que se aplicaban en estos casos, eran el art. 237 C.J.M.:

"Son reos de delitos de rebelión Militar los que se alcen contra la Constitución del Estado, contra el Rey, los Cuerpos Coolegisladores, o contra el Gobierno legítimo..."

En el art. 238 - 2, se fijaban las penas:

"...de reclusión perpetua a muerte a los que se adhieran a la rebelión en cualquier forma que lo ejecuten..."

El Decreto de 2 de Mayo de 1931, había modificado estos artículos, haciendo referencia a las instituciones republicanas.

El Bando de Guerra de 1936, como ya se ha dicho, amplió notablemente, el tipo de rebelión militar.

Todas estas normas fueron utilizadas en el proceso de Miguel Hernández y sirvieron de fundamento legal para su condena.

La calificación de estos casos como delito de rebelión militar es aberrante; además se aplicó retroactivamente. La ampliación de las figuras de la rebelión por el Bando de Guerra es ilegal, atenta a la seguridad jurídica y contradice el principio de no analogía "in malam partem".

Irónicamente se ha dicho que calificar de rebeldes a los defensores del Gobierno legítimo, es la creación de una original figura penal, la rebelión invertida.

Los penados como rebeldes, de acuerdo con la propia legislación tenida en cuenta para condenarlos, no se lavantaron contra el Gobierno legítimo; eran sus juzgadores los que habían consumado la rebelión.

Desde la otra vertiente, con la ampliación de ese tipo, se desnaturaliza tal figura; se castigan así actos que son simples manifestaciones de oposición política, o de 
meras creencias ideológicas (..."ser de tendencias izquierdistas..." etc, que se recogen en las sentencias).

Hay tal laxitud e imprecisión en los tipos que se vulnera flagrantemente la seguridad jurídica y se emplea la analogía en contra del reo. No hay modo de saber, diferenciar, ni separar, la rebelión de la adhesión...

Debe también tenerse en cuenta la falta de proporcionalidad entre las conductas tipificadas como delitos en ocasiones de escasa o nula entidad, y la gravedad (a veces la capital o 30 años) de las penas impuestas, como una infracción más de las garantías debidas.

Pero sí la legislación fue impresentable, la jurisprudencia no le fué a la zaga; más bién, la superó.

¿Cómo determinaban los Tribunales, la figura "menor" de la adhesión a la rebelión -castigada con reclusión mayor a muerte?.

De la lectura de la Jurisprudencia de la época, sobre esta materia, se pueden extraer criterios generales:

La adhesión a la rebelión se acreditaba por la mera compenetración ideológica a la "subversión roja"; bastaba con tener una ideología de izquierdas, simplemente republicana, con pertenecer a un partido político que no fuera de derechas, para que facilmente se declarase acreditado, sin ninguna otra actividad probatoria, la comisión de ese delito.

Casi en todos los casos se apreciaban perversidad y trascendencia, era una pura rutina mecánica, con lo cual las penas se elevan al grado máximo.

Como botones de muestra citaremos, extractadas, algunas sentencias que se comentan por sí mismas:

"Se trata de una mujer de mala conducta, de ideas comunistas, que se incautó víveres y ropas de una Iglesia para confeccionar ropas a un hijo suyo..." (S. 11 de Marzo de 1941).

"Enseña a un niño de 4 años a cantar el himno de la Falange con letra subversiva" (S. 11 de Julio de 1941).

Se condenó a muerte al Fiscal Jurídico Militar -D. Pedro Rodríguez Gómezcomo autor de un delito de rebelión militar por haber mantenido la acusación contra el General Goded.

\section{LA FALTA DE GARANTÍAS JURISDICCIONALES.}

La primera, y más importante de ellas es la privilegiada configuración de la Jurisdicción Especial Militar, en esta época. Las objeciones son su hipercrecimiento, pasa a ser de especial a ordinaria, y la total falta de independencia e imparcialidad de estos Tribunales.

Con las ampliaciones que introducen el Bando de Guerra de 1936, la Ley de 12 de Julio de 1940 y otras disposiciones, todos los delitos políticos, e incluso las con- 
ductas atípicas de opinión o discrepancia política, pasan a convertirse en delito de rebelión.

Son las Autoridades Militares las únicas que pueden declinar su competencia en favor de la Jurisdicción Ordinaria; éstas no pueden reclamar las causas.

No existe independencia en los miembros de estos Tribunales, por lo que carecen de imparcialidad. Son militares, sometidos a la disciplina castrense; han sido designados sus componentes para cada juicio (aunque por razones prácticas, dado el volumen de asuntos, los Consejos de Guerra se constituyesen en este periodo, con carácter permanente) y en todo caso, no gozan de inamovilidad judicial.

Las sentencias de dichos Tribunales carecen de valor, por sí mismas; ha de ser supervisadas y probadas, por el Auditor de Guerra, sin cuyo requisito no son firmes.

No hay ninguna razón objetiva de especialización que justifique la amplitud atribuida a la Jurisdicción Militar de esta etapa. Son auténticos Tribunales de excepción y por tanto procesalmente repudiables.

Pero como es sabido "un régimen autoritario, salvo que quiera perder su idiosincrasia, no puede prescindir de las jurisdicciones especiales" y es por ello, precisamente, por lo que son potenciados en este periodo.

\section{EL PROCEDIMIENTO SUMARISIMO: UNA MAQUINA VULNERADO- RA DE GARANTIAS JURISDICCIONALES.}

En la época de la $2^{\mathbf{a}}$ República el procedimiento sumarísimo sólo se palicó a los delitos estrictamente militares, flagrantes o que tuvieren señalada pena de muerte $o$ perpetua (art. 649 C.J.M. y Decreto 11 de Mayo de 1931).

Por delito flagrante se entendía el que se estaba cometiendo o se acababa de cometer... (art. 650).

Como ya se expuso, el Bando de Guerra de 1936 y la Ley de 12 de Julio de 1940 se remitieron a este procedimiento para "...todos los delitos derivados del Movimiento Nacional, aunque no sean flagrantes...".

Aunque sea discutible la utilización del procedimiento sumarísimo, su aplicación ha de ser excepcional y encuentra su básico fundamento en la flagrancia del delito.

En la regualción de este procedimiento, con las modificaciones de la etapa de 1936 se producen las siguientes vulneraciones de garantías jurisdiccionales:

- La instrucción del Sumario es básicamente inquisitiva. El Sumario es secreto. El defensor no interviene en el mismo.

Incluso este carácter inquisitivo, aunque no de forma tan acentuada, se manifiesta en la fase de preparación del Juicio Oral. El Instructor puede practicar pruebas para el Juicio Oral (art. 657 C.J.M.). El propio Instructor finalizada la investigación realiza un Auto resumen pasando la causa a la Autoridad Judicial (Militar) para que ésta resuelva si ha de pasarlo al Plenario (Juicio Oral), -art. 654-. 
Con estas actuaciones del Instructor se contradicen los principios de imparcialidad objetiva, en la medida que el órgano instrutor realiza funciones propias del Tribunal Juzgador; el principio de inmediación ya que estas pruebas no se practican ante el Tribunal y el mismo principio acusatorio porque el Instrutor con su Auto resumen implícitamente está diseñando la acusación.

- Imprecisión del procesamiento, como después se dirá; en la práctica se incumplian las normas procesales sobre los mismos (arts. 653 y 421 C.J.M.).

- El procesado permanecerá siempre preso (art. $653-1^{\circ}$ ). se vulnera la excepcionalidad de esta medida cautelar, convirtiéndose esta situación en regla general.

- Transgresión de derechos de defensa y falta de igualdad de armas procesales: El Abogado defensor ha de ser siempre militar, no tiene por qué ser licenciado en derecho. No cabe Abogado de libre designación (art. 656 y Ley citada de 1940). Por contra, el Fiscal suele ser el Jurídico-Militar, profesional del derecho; patentizándose una desigualdad en contra del reo.

Y lo que es más importante e inadmisible: Los autos se ponen de manifiesto al defensor, que antes no ha intervenido, "por un término que nunca excederá de tres horas"' -art. 658-. Fijaos bien. Resulta increible pero es cierto. Tres horas para buscar pruebas, proponerlas, estudiar la causa, calificar y preparar el informe. Cuando se está ventilando la pena de muerte o treinta años de reclusión.

Seamos objetivos, hay un principio que, efectivamente no incumplieron estos procedimientos franquistas. Me refiero a las "dilaciones indebidas", mal de nuestra actual justicia.

$\mathrm{Si}$, cierto es, estos procesos no incurrieron en el nefando mal de la lentitud. Eran terriblemente rápidos y ...expeditivos.

- Vulneración al derecho a Recursos, garantía universalmente reconocida, ahora y siempre.

Contra las sentencias dictadas en el sumarisimo no cabían recursos; sólo alegaciones verbales del acusado. Eran "firmes con la aprobación de la Autoridad Judicial del Ejército o Distrito, de acuerdo con su Auditor" (Art. 622).

En la Circular de 2 - XI - 1936, de la Presidencia del Consejo Supremo de J.M. se decía en su art. $1^{\circ}$ :

"Se entenderá limitada la posible interposición de recursos a aquellos procedimientos que no tengan carácter de sumarísimos".

Por último debe, recordarse, como antes se anticipó, el sistemático incumplimiento de las garantías respecto de los procesamientos, que se hacían de forma mecánica y rutinaria.

$\mathrm{El}$ art. 653 C.J.M. disponía que "la tramitación de los juicios sumarísimos se arreglará a la del juicio Ordinario en todo aquello que no esté modificado". Y para los procesamientos no se establecía ninguna especialidad.

En las normas generales, art. 421 - 2 C.J.M., y se dice:

"El procesamiento se acordará en diligencia, MOTIVADA, en la que consignarán los hechos y fundamentos de derecho que lo determinen". 
Y este fué el procedimiento sumarísimo que se aplicó en el proceso de Miguel Hernández; así se le procesó. Brillaron por su ausencia todas las garantías jurisdiccionales comentadas.

\section{LA LEY DE RESPONSABILIDADES POLITICAS DE 9 DE FEBRERO DE 1939.}

Haremos una sucinta referencia a esta Ley. Paradigma de la conculcación de la más elementales garantías. Pieza del museo del legislador, para que sepa lo que nunca debe hacer.

En nuestro caso, no se aplicó prácticamente; ante la indigencia del penado. Pero así se acordó en la Sentencia.

Los males más llamativos de la Ley eran:

Su retroactividad. La aplicaban órganos administrativos, llamados Tribunales, carentes de independencia e inamovilidad; nombrados por el Gobierno. Su única finalidad era la incautación de los bienes del condenado, la imposición de multas, inhabilitaciones (muertes civiles) y la pérdida de la nacionalidad.

El procedimiento era totalmente inquisitivo; el propio Juez que instruía, acusaba y proponía la sanción, elevaba un resumen al Tribunal superior que fallaba. No intervenía el Fiscal -aunque posteriormente se admitó-. Secreto del Sumario. Practicamente se excluía el derecho de defensa; sólo se permitían alegaciones (sin Abogado) con prueba tasada: documental y testifical. La responsabilidad no se extinguía con la muerte. Se quebrantaba el principio de "non bis in idem", ya que se aplicaban después de las sanciones penales, las de esta Ley.

En la condena a Miguel Hernández se le aplicó esta Ley. La decisión del Tribunal esta vez no pudo cumplirse; el penado se hallaba y murió en la más desamparada y digna de la pobrezas. El único patrimonio que le quedaba era su caudal poético y ni esa propia Ley, tan aberrante, encontró una fórmula eficaz para embargarlo.

\section{SINOPSIS CRITICA DE LA SENTENCIA CONDENATORIA DE MIGUEL HERNANDEZ.}

Hemos analizado lo particular (el proceso de Miguel Hernández), hemos valorado críticamente el derecho penal y procesal aplicado en ese proceso, nos quedaría por ver una síntesis crítica de la Sentencia.

Recordemos, en lo esencial, los hechos que se declaran PROBADOS:

- Antecedentes Izquierdistas. ¿En delito?.

- Incorporación como voluntario al $5^{\mathfrak{Q}}$ Regimiento.: No aparece probado; el acusado afirma que fue movilizado por su reemplazo, y no existen pruebas de cargo sobre tal extremo.

- Pasó al Comisariado Político; solamente queda acreditado que formó parte del Comisariado de Propaganda. 
- Dedicado a actividades literarias y miembro acitvo de la Alianza de Intelectuales Antifascistas. Probado. ¿Es delito de adhesión a la rebelión?.

- Publicó numerosas poesias, crónicas y folletos de propaganda revolucionaria, hoy sin piezas poéticas mundialmente reconocidas.

- Excitación contra las personas de orden y el Movimiento Nacional ¿En qué consisitieron tales actos concretos? En todo caso, ¿una defensa literaria, verbal o escrita, del Gobierno legítimamente constituido y del pueblo que lo había respaldado en las urnas electorales, es una adhesión a la Rebelión?

- Se hizo pasar por Poeta de la Revolución. Sin comentarios.

- ¿Estamos ante un acto de justicia o de venganza de vencedores?. Cada uno que dé su respuesta.

El Tribunal fue un órgano de excepción, carente de independencia e imparcialidad.

Se vulneraron las garantías del derecho de defensa, de aportación de pruebas, de igualdad de armas procesales, de utilización de recursos. Las penas eran absolutamente desproporcionadas. Estamos ante un simulacro de proceso, falto de las más elementales garantías para poder ser calificado de proceso justo, o debido, aún teniendo en cuenta las especiales circunstancias de aquellos momentos.

\section{Y... PUNTO FINAL.}

...Hasta aquí hemos caminado juntos. Ojalá se haga realidad en nosotros la afirmación clásica: "La Historia es el instrumento por el que el hombre se libera del pasado".

- Ojalá: La España de la rabia y de la idea, la España que alborea, nos depare un mañana más prometedor.

Porque nosotros, también creemos, que la Justicia es un arma cargada de futuro. Gracias.

\section{BIBLIOGRAFIA CONSULTADA}

- La Ley de Responsabilidades Políticas de Máximo Cajal. Madrid 1939.

- La Administración de Justicia durante la Guerra Civil en la España Nacional. (En el libro "Constitución, Jurisdicción y Proceso"), de Ernesto Pedraz Penalva - Madrid. 1990.

- Política y Derecho Penal en España, de Marino Barbero Santos, Madrid 1977.

- Modernización, autoritarismo y administración de Justicia en España (Suplemento de Cuadernos para el Diálogo) de Jose-Juan Toharia, 1974.

- Derecho represivo en España durante los periodos de guerra y posguerra (1936-45), de Igancio Berdugo de la Torre, en № 3 Monográfico de la Revista de la Facultad de Derecho Universidad Complutense - Madrid. 1980. 
- Politica Criminal y derecho Penal en la Guerra Civil y en la Posguerra, Antonio Beristain Ipiña, en R.I.D.P. 1978, I.

- El Derecho penal de la Posguerra en Problemas actuales de Derecho Penal y Procesal, Salamanca 1971 - A. Jose Antón Oneca.

- Los procedimientos antiterroristas en el "Nuevo Estado" (1939-1945) Jose María Asencio Mellado, (Memoria de Licenciatrura Alicante 1983 inédita).

- El Código de Justicia Militar al día, de R. Escobar Huerta, Valencia 1914.

- Proceso a Miguel Hernández, el Sumario 21.001, de Juan Guerrero Zamora. Madrid 1990.

- España Estado de Derecho. Réplica a un informe de la Comisión Internacional de Juristas. (No figura autor) Madrid 1964.

-. Guerra Civil y Franquismo en Alicante. Glicerio Sanchez Recio. Jose $\mathbf{M}^{\mathbf{2}}$ Santacreu Soler, Miguel Ors Montenegro, Roque Moreno Fonseret y Francisco Moreno Saez, Alicante 1990.

- Depuración y reforma de la Administración de Justicia en la Provincia de Alicante durante la Guerra Civil de Glicerio Sanchez Recio; Artículo en Anales de la Universidad de Alicante, Historia Contemporanea - no 61987 - 88, Alicante.

- La represión de la Guerra y la Posguerra en Alicante, de Miguel Ors Montenegro idem Revista anterior.

- Justicia y Guerra en España. Los Tribunales Populares (1936-39) de Glicerio Sanchez Recio, Alicante 1991.

- La Justicia Popular durante la Guerra Civil, de Glicerio Sanchez Recio. Revista Arbor $\mathbf{n}^{\mathrm{o}}$ 491-92, Madrid. 1986.

- Las Responsabilidades Políticas en la Posguerra Española. El Partido Judicial de Monovar de Glicerio Sanchez Recio. Universidad de Alicante. 1984.

- Justicia en Guerra. Jornadas sobre la Administración de Justicia durante la Guerra Civil Española: Instituciones y Fuentes documentales. Salamanca 26 al 28 de Noviembre de 1987. Ministerio de Cultura. Madrid 1990.

- El Proceso de Besteiro, de Ignacio Arenillas de Chaves. Revista de Occidente. 1976.

- Alicantinos en el Exilio. (Monográfico de diversos autores) Revista Canelobre nº 20/21. Alicante 1991.

- Ley de Oden Público de 28 de Julio de 1933. Colección Popular de Leyes. Madrid 1933.

- Legislación Española. Leyes Penales. CYLE. Madrid 1934.

- Leyes Penales de España. Medina y Marañón. Madrid 1876. Madrid 1947. 


\title{
NOTAS SOBRE EL ARBITER ROMANO Y SU POSIBLE RELACION CON EL IUDEX
}

\author{
CANDIDA GUTIERREZ GARCIA \\ Profesora de Derecho Romano
}

Estas notas surgen dado que el hombre en el momento que se une a otros para vivir en sociedad, afluyen desacuerdos que amenazan la convivencia, la armonía y la paz, por ello busca desde un principio medios de solventarlos y establecer el orden.

Tres son los medios utilizados por el hombre para conseguirlos:

$1^{\circ}$ La via de transición, que no precisa la asistencia ajena y las partes son sus propios jueces, resolviendo las diferencias con acuerdos que ellos mismos deciden mediante cesión de derechos por ambas partes.

$2^{2}$ La vía judicial, a la que acuden las partes para someter sus debates a la autoridad pública. Medio cierto, pero sin duda el más riguroso y complicado que aparece en Roma cuando ya existe como Estado avanzado que puede permitirse la intromisión en la vida de sus ciudadanos.

$3^{\circ}$ La via de arbitraje, medio que sin presentar las ventajas de los precedentes, al menos tiene el privilegio de ser la primera en Roma a la que acuden aquellas partes que intentan sustituir la venganza privada, buscando la equidad, aún cuando en un principio se limitaron simplemente a la asistencia como testis sin intervenir directamente en la controversia, para dar una solución.

La ventaja que presenta esta vida es quizá, su sencillez y simplicidad, lo que permite una solución rápida al conflicto existente entre los individuos. Por el contrario, el juicio es siempre largo y complicado, por ello, se recurre frecuentemente a esta tercera via para evitar los inconvenientes de los otros dos.

El Estado Romano consciente de la utilidad de esta institución y de la frecuencia con que se accede a ella, a pesar de la existencia de procesos, decide no sólo admitirla como tal y que conviva con ellos, sino que la presta atenciòn y protección, dictando aquellas prescripciones, cuya violación supone la nulidad de la convención y por ello la anulación de la sentencia emitida.

Dada la implicación de esta institución en el mundo jurídico, estas notas pretenden suscitar el tema de la existencia de cierto paralelismo arbiter-iudex en lo que se refiere a su función juzgadora, aún cuando existan diferencias notables entre uno y otro en virtud de los diversos actos sobre los que deriva el nombramiento de cada uno de ellos.

El término iudex que no siempre fué empleado con indéntico significado, indicaba en un principio aquellos que podian ius dicere, siendo estos los magistrados que en virtud de su imperium ejercian funciones jurisdiccionales, regulando direc- 
tamente la controversia entre privados y estatuyendo caso por caso el derecho, denominación que más tarde se sustituyó por la de praetor y consul (1).

Cuando el proceso romano comienza a desarrollarse en dos fases, ya no será el iudex quien ius dicit sino, el que en la segunda fase despues de recoger pruebas y siempre limitado al planteamiento llevado a cabo en la primera fase por el magistrado dicte sentencia.

El magistado juntamente con las partes nombrará por sorteo un juez, de una lista previamente elaborada de ciudadanos romanos, no necesariamente sui iuris y de la que serian excluidos (2) mujeres, mudos, sordos y dementes, así como los menores de treinta años, en principio y de veinticinco a partir de Agusto, también se consideraron excluídos para el ejercicio de iudex aquellos que estuvieron ejerciendo función pública y en especial los revestidos del mismo o superior imperium del que gozaba el magistrado que presidia el juicio (3).

Este juez era susceptible de recusación por parte del demandado que no venia forzado a aceptarlo categoricamente siempre que tuviese motivo justo para hacerlo; y él a su vez podía excusarse y no aceptar el encargo de dictar sentencia, si estaba incurso en aquellas circustancias reconocidas como válidas para ello, como sería enfermedad, oficio público, necesidades familiares etc.

Cuando el juez asume esta función la relación con el árbitro se pone de manifiesto, y en las fuentes clásicas encontramos apoyo a esta tesis, debido a que usan indistintamente la palabra iudex-arbiter (4) para hacer referencia a aquel que venia investido de la potestas iudicandi.

Sin embargo a pesar de ello no podemos aceptar este paralelismo de forma y considerar como una misma figura ambas instituciones (5), aunque tampoco parece admisible aquella otra que rechaza cualquier posible relación sobre todo en época avanzada (6).

Compartimos más aquella otra tesis intermedia que considera que partiendo de una distinción originaria entre iudex-arbiter se pasará en el proceso formulario a una deferencia mínima, si bien, de las fuentes parece derivarse cierta predilección por el término arbiter al que se le reconocía mayor poder discreccional (7).

Es posible deducir también que no pueden ser catalogados de figuras contrapuestas, del hecho de que cuando el iudex por particulares circustancias precisa venir revestido de más amplios y descreccionales poderes, se le denomina arbiter y el proceso que lleva a cabo se le denomina arbitrium.

Wlassak nos informa que el nombre de árbitro no difiere en nada del de juez y que con el concurso de otras circustancias necesarias es legitimum el proceso en el que el órgano que juzga es el árbitro (8).

De igual modo podemos argüir cierta relación entre el llamado arbiter datus y el iudex datus cuando en época clásica y fuera del proceso ordinario era nombrado por el magistrado para aquella ocasión que siendo precisas medidas magis imperii quam iurisdictionis se acudía a él.

Africano justifica este nombramiento cuando existe un motivo cum controver- 
sia et computatio difficilior esset. A este árbitro se le ha venido identificando con el llamado iudex datus que aparece a partir del S-III d.C. como juez auxiliar que en el procedimiento extraordinario era funcionario delegado de un magistrado superior conociendo, de los asuntos que le competían a éste. Este árbitro, sin embargo, no decidía sobre una litis, sino que se limitaba a la investigación y valoración técnica sobre cuestiones de hecho, cuando se precisaban para preparar la sentencia, o bien para situaciones ocasionales que vendrían determinadas estrictamente (9).

Ya en época post-clásica en la cognitio-extraordinem arbiter venia a ser el iudex y en definitiva, son identificados igualmente, apareciendo como particular el caso de los árbitros elegidos por las partes despues que ante litem contestatum habian recusado al iudex datus (10).

En cuanto que ejercen su función buscando el mismo fin o resultado, como es emitir sentencia -no siendo siempre consegido- sin embargo no están sometidos al mismo grado de exigencia de responsabilidad en caso de no cumplir con esta obligación, derivándose ella de la forma en que uno y otro son nombrados.

Las partes que recurren a una u otra vía buscan la emisión de una sentencia, y es preciso por ello asegurarles que su fin será cumplido y que la cuestión que plantean será debatida y solucionada.

El magistrado obligará tanto al iudex como al arbiter a cumplir la función que han asumido como deber esencial que es.

Cuando el juez nombrado, acepta su cargo, su obligación es dar sentencia, de manera que si llegado el momento y sin causa que lo justifique no lo hace, incurrirá en responsabilidad (11). Llegando incluso en época justinianaa a alcanzar la ausencia de sentencia categoría casi delictual (12), apoyándose en el sistema de responsabilidad objetiva.

No hay acuerdo por parte de la romanística sobre si la responsabilidad del juez viene limitada al hecho de dar o no sentencia, o si por el contrario también se le exigiría al juez cuando siendo la condenatio certa, condenara a más o menos de la cantidad señalada, o que señalando una taxatio el juez no se atuviera a esa orden, debido a que las fuentes presentan párrafos que apoyan tanto una tesis como la otra (13).

Sin embargo la tesis más admitida y que comparto es aquella que considera que el juez vendría sometido a responsabilidad sólamente en el supuesto de no dar sentencia, en cambio no vendria incluida la responsabilidad por actuación inconveniente, pues aunque el juez estuviera obligado a un comportamiento correcto a lo largo de la fase apud iudicium en virtud de su juramento (14), éste sólo le vinculaba en su fuero interno eximiéndole al tiempo de cualquier reclamación que se intentará contra él.

No viene al caso cual sería la sanción con que el juez sería castigado ni si ésta evolucionó; la pretensión no es otra que establecer que el juez vendría obligado por su oficio a dictar sentencia desde el momento que asumió el cargo y no se excusó (si tenia causas suficientes) de la misma manera que venia obligado el árbitro que 
habiendo asumido su oficio no dictara sentencia, si tampoco utilizó las excusaciones que también tenia reconocidas.

Ahora bien, solo estaria obligado a dictar sentencia el arbiter ex compromiso, es decir, aquel que asumió el cargo mediante receptum, pues hemos de diferenciar a éste de aquel árbitro primitivo que actuaba como simple mediador, y cuya única función era la de actuar tratando de conciliar a las partes, escuchando sus alegaciones, asistiendo e iluminándolas con sus consejos, ésto no sería evidentemente una sentencia.

Será más tarde, y conforme el concepto de justicia se afirma como sanción esencial del Estado que interviene en la vida de sus ciudadanos, cuando el pretor puede actuar obligando al árbitro a emitir sentencia siempre y cuando éste haya accedido al cargo mediante receptum y dejará de ser observador, conciliador y testimonio para desarrollar una función más amplia y general que decide según sus propias convicciones y autoridad.

Cuando las partes de acuerdo mediante un compromiso para someter a arbitraje una controvertida relación jurídica y mediante la petición a un tercero para que actue como árbitro, éste acepta, esta actividad se convierte en arbiter ex compromisum. Es entonces, cuando el arbitraje viene elevado a verdadero instituto jurídico y el pretor comienza a intervenir para garantizar a las partes la labor jurídica juzgadora a intervenir para garantizar a las partes la labor jurídica juzgadora siendo preciso el recipere del árbitro, para que quede obligado a dictar sentencia, por lo que quedará sometido a la coercitio praetoria en caso de incumplimiento (15).

El Estado en estos casos no sólo acepta el arbitraje sino que garantiza a las partes que han elegido este medio para dirimir la controversia existente entre ellos, la posibilidad de que venga asegurada la decisión, castigando al árbitro que desobedezca el mandato del magistrado que emana en virtud de su imperium mediante multa o pignoris capio.

La jurisprudencia Romana a partir de una claúsula edictal que prevé la intervención del pretor para constreñir al árbitro a pronunciar sentencia, elabora este instituto, poniendo de manifiesto cual era el sentir de los jurisprudentes en esta institución y que nosotros hemos podido constatar a través de numerosos pasajes (16). El árbitro venia obligado a dictar sentencia salvo que estuviera exento por causas justificadas, reconociendo por ejemplo suficiente, el hecho de que se le hubiera hecho injuria, despreciándole al acudir a otro árbitro y volviendo después a él.

Por supuesto nunca vendría obligado mientras no mediara compromiso y una vez que receptum arbitrium (17); tampoco podría ser obligado cuando haya sido cancelada por acceptilatio la pena del compromiso a uno de los compromisarios (18). De la misma manera que no vendría forzado aquel árbitro que, mediando un compromiso de que actue en un determinado sentido, no tuviera libertad para ejercer la función conforme a su parecer.

De todo ello puede deducirse que salvo causas justificadas, por las que pueda ser excusado el árbitro a cumplir con su función juzgadora siempre quedaría sometido a la coercitio praetoria en caso de no hacerlo. 
Es este arbiter ex compromisso el que presenta semejanza con el iudex, sobre todo en cuanto al sometimiento de ambos a la exigencia de dictar sentencia, cuando aceptaran la función de juzgar, aún cuando el modo utilizado para exigir esta obligación era distinto. Creemos por tanto que ambas figuras presentan gran similitud funcional, aún cuando esto no comporte identidad estructural.

El árbitro tiene que atenerse a la hora de juzgar al programa acordado por las partes en el compromiso (19) secundum forman compromissi principio que marcha paralelo a aquel que surge del proceso ordinario (20).

Una vez emitida la sentencia cesa en su oficio de manera automática y no puede modificarla (21).

Comunes son también para ambos institutos los principios que regulan la validez de la sentencia, cuando siendo más de uno los jueces o árbitros precisa que estén necesariamente todos presentes y todos deben juzgar (22) siendo admitido y prevaleciendo el acuerdo mayoritario cuando existan distintos criterios (23).

Igualmente son semejantes en cuanto al contenido de la sentencia emitida por ambos de manera que pueden dictar: a) aseguramiento, nihil videri Titium debere Seio (24), b) condena o absolución cum constet Titium Seio dicetum condemno (25), c) adiudicatio (26).

Siguiendo con el contenido de la sentencia, el de ambos debe ser determinado, no siendo válida una sentencia que diga: cuantum ei debes reddes o bien, divisionis vestrae stare placet; su similitud también alcanza en cuanto al caracter pecuniario que debe tener la condena. Ahora bien, con caracter general se acepta por la doctrina, que la sentencia en los juicios ordinarios era siempre pecuniaria (27), no era así en lo que se refiere a que la sentencia arbitral hubiera de tener siempre esta naturaleza.

Otra pregunta que cabe hacerse con respecto a la posible relación entre la figura del árbiter y del iudex es que si una vez emitida la sentencia sea de manera voluntaria u obligatoria por el magistrado ¿alcanza el mismo grado de fuerza obligatoria la sentencia de uno y otro ?, es de suponer que así como hemos podido establecer cierto paralelismo en su obligación a la hora de emitir sentencia no será lo mismo una vez emitida, dada la diferencia existente entre un indicium y un arbitrium.

Por lo que respecta a la sentencia dada por el juez y a través de la evolución sufrida por el proceso Romano, vemos que si en un principio en los juicios llevados a cabo a través de las legis actiones la sentencia del juez venia simplemente a designar opinión o convicción jurídica del iudex privatus sobre la cuestión litigiosa, de manera que sólo producía efectos indirectos respecto de la satisfacción del derecho que el demandante pretendía hacer valer el juicio, más tarde cuando se llevan a cabo a través del procedimiento formulario los efectos producidos son directos sobre las partes, aún cuando la sentencia conserve el caracter que tenía anteriormente expresando también el criterio del juez como final de un proceso lógico mental.

A través de la evolución histórica, la afirmación que contiene la sentencia llega a alcanzar un valor peculiar que se concoce con el nombre de "autoridad o santidad de la cosa juzgada" (res iudicata). Llegando pues, a un momento en que la senten- 
cia pronunciada por un juez, valdrá como "verdad" entre las partes, merced a la cual éstas podrán en un futuro invocar su fallo, asumiendo la obligación de acatarlo, lo que supone que la sentencia dictada ha resuelto definitivamente la cuestión litigiosa. Ya nunca podrá plantearse un nuevo litigio que contenga idéntica materia litigiosa, aquello que conocemos como eadem res o eadem quaestio.

La sentencia emitida por el juez se hace de obligatorio cumplimiento, de manera que si el condenado no paga al demandante vencedor la suma establecida en la condena, éste, pasados treinta días podría actuar con la actio iudicati (28) y comenzaba el proceso ejecutivo.

Sin embargo, no podemos aceptar el mismo grado de obligatoriedad para el laudo arbitral, ya que éste nunca tendrá fuerza de cosa juzgada: ex compromisso... iudex sumptus rem indicatiorum non facit (29), constituye unicamente para el perdedor carga o gravamen, en cuanto que viene obligado, en caso de no acatar la sentencia del árbitro a pagar la cantidad que anteriormente habian estipulado por compromiso.

La parte ganadora por el contrario, no tiene medio alguno para exigir el cumplimiento de la condena a la parte perdedora; si el condenado opta por pagar la poenae compromissi no podrá ser compelido aún cuando el demandante prefiera que se cumpla. Tampoco tiene fuerza de cosa juzgada, pues si lo desean podrán acudir a un proceso ordinario, y presentar la misma controversia suscitada ante el árbitro. De esta forma, las partes son libres de pagar la pena o cumplir la sentencia, pena que anteriormente las partes habian acordado en el acuerdo compromisario y solo a ello podrán ser obligadas por el pretor, no pudiendo ser apelada la sentencia arbitral.

Todo ello no significa que no hubiera posibilidad de remedio a la sentencia emitida por el árbitro, pues desde los rescriptos de Caracalla (30), del siglo III d.C. se concedia frente a la actio ex stipulatu con que se reclamaba la pena que se había acordado en el compromiso, cuando la parte perdedora no acatara la sentencia, una exceptio doli en caso de que la sentencia del árbitro fuera dolosa. Esta misma solución se dió en otros rescriptos por los emperadores Diocleciano y Maximiano.

El Digesto también recoge la concesión de esta exceptio cuando el árbitro que emitió sentencia fuera enemigo manifiesto de una de las partes (31) o cuando exista venalidad o favor de los árbitros (32).

Es la época justinianea cuando ya se concede una actio in factum al actor victorioso $(\mathrm{C} 2,55,5$ de receptis: quatenus possit sententiam... excusationi mandari) y al demandado absuelto la defensa por medio de una exceptio cuando la misma controversia fuera decidida en juicio.

Queda pues, manifiestamente probada la diferencia existente entre la sentencia del iudex y la del arbiter en lo referente a su caracter obligatorio, por lo que en este aspecto no creemos posible establecer ningún lazo de relación entre ellos.

Y como en principio se anunció, a pesar de que en algunos aspectos si hemos considerado existente cierto paralelismo entre ambas instituciones en su función juzgadora, la diferencia entre la decisión de una y otra descansa sustancialmente en la forma distinta de su nombramiento, pues mientras el árbitro es elegido por las 
partes sin intervención del magistrado, que ni siquiera coopera en el nombramiento y que sólo podía compeler al árbitro reaccio, como dice en su edicto (qui arbitrium receperint ut sententian dicant (33)), al que habiendo aceptado el cargo y no estando incurso en causa de excusatio (34), será castigado con una sanción administrativa (multa o pignoris capio); el nombramiento del juez es, en cambio hecho por el magistrado junto con las partes litigantes, acto magistral que recibe el nombre de iussus iuducandi y que será la base de la potestas iuducandi del iudex frente al del árbiter en su acto de aceptación o receptum arbitri.

\section{NOTAS}

(1) VARRO, De lengua latina 6, 88; LIV,3,55; CICERON De Leg. 3,3,81 hacen alusión a estos.

(2) ULP 13 ad, ed D 5,1,12,12.

(3) PAUL 13 Sab D 5,1,58.

(4) CICERON de off 3, 16,66.

(5) WLASSAK, Der Röm Precessgesetze vol II, p. 287 y ss.

(6) KELLER-WACH Der Röm Civilprozess 6ª el Leipzig 1883, p. 33 y ss.

(7) BONIFACIO Arbitrio e Arbitratore (Diritto Romano) en Nov Dig p. 925 y ss.

(8) WLASSAK, op cit p. 43 y ss.

(9) Ej. arbiter de rationibus reddentis, en caso de libertad fideicomisaria condicionada a la rendición de cuentas (Marc. 2 inst. D 40,1,5,1); arbiter de alimentis patroni cuando se estima que un patrono carece de medios de subsistencia y el liberto tenga de sobra (Ulp. 2 de off const D $25,3,5,25$ ) arbiter cuius interventu tribuantur merces peculiares (Ulp. 11, ed D 4,4,7,1) etc.

(10) $1, \mathrm{C}$ de iud 3,1 a 531 .

(11) D 5,1,74. 42. 1,55.

(12) CREMADES Y PARICIO La responsabilidad del juez en el Derecho Romano clásico en "Estudios en homenaje al profesor D'ORS" 1989 p. 180.

(13) GAYO 4,52 recoge la responsabilidad de un juez que condena a más o menos de la cantidad señalada. ULPIANO 51 ad sab D 4,2,1,55 señala por el contrario que un juez que condene a más o menos no puede alterar su sentencia, pues male seu bene officio functus est de forma que una vez emitida la sentencia, lo haga bien o mal, el juez ha cumplido con su deber.

(14) LUZZATO Procedura civile romana II, 1948 p. 229.

(15) LENEL, Das Edictum Perpetuum Leipzig 1927 p. 13 a 131.

(16) D 4,8 recoge los casos de responsabilidad asumida y dice" qui arbitrium receperit sententiam dicant.

(17) D 4,8,13. 2: Recepisse autem arbitrium videtur, ut Pedius lib nono dicit, qui iudicis partes suscepit finenque se sua sententia controversiis impositorum pollicetur.

(18) D 4,8,13.

(19) D 4,8,32,15 y $16,17,21$.

(20) GUARNIERI BIDR XXXIII 1923.

(21) D 4,8,19,2 ...ceterum si condemnavit vel absolvit, dum arbiter esse disient, mutare sententiam non posse.

(22) D 42,1,37: Tunc enim universi iudices iudicare, iudicavit ratum est y D 4,8,27,33.

(23) D 4,8,18: ...quia id demum quod maior pars omnium iudicavit ratum est y $\mathrm{D} 42,1,39$. 
(24) D 4,8,21,1.

(25) D 49,8,1 y D 4,8,19,2.

(26) D 4,8,21,3.

(27)PARICIO dice, en Notas sobre la sentencia del arbiter (RIDA XXXI) que "incluso en aquellas acciones que propiamente no iban dirigidas al pago de una cantidad y también en aquellos casos que se precisaba el restituere o reddere oexhibere aunque quedaba supeditada a la no restitución, devolución o exhibición de la cosa".

(28) La actio iudicati es una de las acciones quae infitiando in duplum crescunt.

(29) PAUL sent 5,5 a1.

(30) VOCI la responsabilitá del debitore da stipulatio poenae en Studi Volterra II, 1971 p. 334 y ss.

(31) D 4,8,32,14: Cum quidam arbiter ex alis causis inimicus manifeste apparcuisset.

(32) C 1,2,55,3: si sordes vel evidens gratia eorum qui arbitrati sunt intercessit.

(33) LENEL edic prep Leipzig 1956, $3^{2}$ ed p. 130.

(34) D $4,8,11$ y 15,16 . 


\title{
RECEPTUM ARBITRI
}

\author{
CANDIDA GUTIERREZ GARCIA

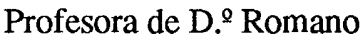

\section{1.- RECEPTUM - ARBITRI}

\subsection{Aceptación del árbitro}

El concepto de Receptum-arbitri viene dado por el hecho de que cuando las partes se ponen de acuerdo mediante un compromiso para el arbitraje de una contravertida relación jurídica, existente entre ellos, por mediación de un árbitro avenidor, en lugar de recurrir a un juez secular, entonces además de esta decisión de las partes, será preciso la libre aceptación de este cargo por parte del árbitro (1), pues podrá aceptar o rechazar el propuesto arbitraje:

Tametsi neminem praetor cogat arbitrium recipere quoniam haec res libera et soluta est et extra necessitatem iurisdictionis posita... (2).

Si, como decíamos, el elegido acepta esta actividad, entonces se convierte en arbiter ex compromisso (3). Por lo general, el árbitro actúa individualmente, aún cuando se puede designar conjuntamente varios, constituyendo así un colegio arbitral.

El curso normal que debe seguir para aceptar el cargo es que el receptum siga al compromiso de arbitraje; pero se ha considerado por algunos autores la posiblidad de que puede seguirse la operación inversa, siendo posible que preceda el receptum al compromiso realizado por las partes.

Los autores que opinan así, rechazan, sin embago, el que pueda ser obligado el árbitro de manera más amplia a la extensión del receptum realizado por él (4).

Esta teoría resulta difícil de admitir, teniendo en cuenta que el árbitro venía sometido al compromiso y sólo podía actuar conforme a él, por lo que si él primeramente aceptaba el cargo no sabría hasta donde se comprometía, pues las partes, al realizar el convenio, podían hacerlo de manera amplia y se encontraría indefenso en ese aspecto.

La aceptación del cargo por parte del árbitro se llama recipere:

Recepisse autem arbitrium videtur, ut Pedius libro nono dicit, qui iudicis partes suscepit finemque se sua sententia controversiis impositurum pollicetur (5).

Menos claro aparece en un texto justinianeo:

qui ex recepto id est compromisso quiod iudicium imitatur causas dirimendas suscipiunt. (6).

En cuanto a la forma en que debe llevarse a cabo el pacto de Receptum arbitri, no tenemos noticias de que vinieran impuestas formas taxativas; se trataria más bien 
de una promesa sin ceremonias de naturaleza propia, efectuada por las partes en el compromiso de arbitraje. Ha sido considerada en algunas ocasiones erróneamente como perteneciente a la locatio-conductio y más frecuentemente al mandatum (7). $\mathrm{Y}$ así como con el compromiso hacia otras operae liberales se llega a una demanda a modo de la extra ordinem cognitio, falta esta evolución en el caso del receptum arbitri; ello posiblemente se debe a que se trata de un instituto jurídico que se ha estancado en su desarrollo, bien sea porque la actuación del arbiter no ha sido evaluable o porque su oficio no era claramente jurídico-privado (8). Algunos autores opinan que el Receptum es un pacto o contrato, pero no una mera y simple declaración del arbiter de su voluntad de juzgar; sin embargo, otros (9) admiten la existencia de un juramento del arbiter para asegurar a las partes que haría el arbitraje con la mejor conciencia y voluntad posible (10).

Parece poco probable que siempre se pidiera al árbitro efectuar tal juramento, ya que si así fuera, el Digesto, que tan detalladamente nos habla de toda la actuación del árbitro, no lo hubiera pasado por alto.

Hay posturas encontradas en este punto entre los autores, ya que algunos son partidarios que de sí era preciso el juramento antes de Justiniano (11) y por el contrario, la mayoría opina que esto fue así sólo desde Justiniano (12).

WLASSAK no adopta una posición segura contra la necesidad del juramento, y WENGER (13) considera que "las partes tendrían libertad de acción en concretar el juramento del arbiter entre sí y después con él".

Independientemente de aceptar una u otra tesis, lo que ciertamente ocurre es que el contrato del arbiter con las partes entra en la esfera coercitiva, tan pronto como el praetor ad curam et sollicitudinem suam hanc rem pertinere putat (14).

El pretor, sin embargo, excluye de su coerción ciertos litigios porque considera que no son susceptibles de gestión arbitral; son aquellos en que la sentencia puede venir vinculada a un interés público y jurídico; también vinen excluidos aquellos procesos que tratan sobre la libertad y la ingenuidad (15), así como los casos de actio popularis (16).

La coerción contra el árbitro se rehusara, pues, si de negotio transactum est, vel homo mortuus est de quo compromissum; nisi si posteriore casu aliquid litigantium intersit (17). Un proceso sucesorio tampoco podrá se arbitrado, y por tanto prejuzgado, ergo interea inhibendus est arbiter (18).

Justiniano negó la posibilidad de proceder a una Restitutio in integrum a los compromissarii iudices vel arbitri ex communi setentia electi (19).

No sabemos con certeza si en tiempos de Cicerón existía ya un edicto de coercitione; los casos que menciona el orador no contienen ninguna alusión al respecto (20). Pero si la hipótesis de Partsch (21) sobre el contrato de garantía del edicto a través del receptum y la supuesta recepción de estas prescripciones contra banqueros y posaderos, por parte del derecho de tráfico griego, se confirmará como auténtica, entonces no sería difícil aceptar para el primer receptum acogido en el edicto (22) mayor antigüedad. 
La compulsión positiva por parte del pretor obligándole a dictar sentencia, sólo la hará previa petición de una de las parte; sin embargo, por propia iniciativa intervendrá el pretor para prohibir en casos determinados dictar sentencia, así, por ejemplo, cuando se haya recurrido erróneamente a la decisión arbitral, en aquellos asuntos que no son susceptibles de ser sometidos a ella porque existe una acción pública para ello.

Cuando el pretor aplica medios coercitivos al árbitro incumplidor, debe tener en cuenta antes si aquel que aceptó el cargo está dentro de la categoría de personas que están sometidas a él y, por tanto, pueden ser constreñidos a cumplir. Si se trata de sujetos que tengan maior potestas que él, no tiene poder para ello, ya que no están sometidos a su imperium, salvo que no estén desempeñando, en ese momento, una magistratura, como cónsul o pretor. Los magistrados inferiores, en cambio, pueden ser obligados por el pretor.

Independientemente de ello, el magistrado que se encuentre ante un árbitro que estuviese ejerciendo igual o mayor magistratura puede y debe fijar las condiciones personales y objetivas exigidas para poder emitir una sentencia.

Cuando el árbitro acepta el cargo, y no existiendo ninguna causa que le incapacite, como sería el ser servus, pupilus, furiosus, surdus et mutus, así como cuando no se acoja a quellas situaciones que le permitan negarse (excusationes), tales como obligaciones religiosas, públicas propios procesos urgentes, enfermedad e incluso alia incomoditas (23) o cuando existan estas incapacidades post arbitrium susceptum, vendrá obligado a dictar sentencia y, en caso contrario, el pretor, en virtud de la promesa que hace en su edicto de proteger las situaciones nacidas de este receptum, le exigirá responsabilidad ante su incumplimiento.

Sin embargo, no hay acuerdo en cuanto a lo que supone este receptum para el árbitro, esto es, si mediante él el pretor pretende aumentar su responsabilidad o, por el contrario, mitigarla.

Yo me inclino por la tesis que defiende Do Robertis, que considera que, a través de estos pactos, el pretor intentó mitigar las responsabilidades de aquellas personas que venían ejerciendo profesiones que por su dificultad, les colocaba en una situación indefensa; nos referimos principalmente al nauta, quien, ante los peligros que ofrece el mar y, por tanto, la inseguridad de que lleguen al término previsto las mercancías, no estaría obligado más que cuando expresamente ellos lo aceptasen (y que es de suponer, lo harian siempre que la retribución fuese mayor, ofreciendo así lo que hoy llamamos un seguro de transporte).

Aceptando esto y considerando que en tales casos el receptum lo que hacía era obligar, porque así las partes, voluntariamente, lo habían querido, no se puede considerar un aumento de responsabilidad sino que, por el contrario, sólo será exigido hasta donde la haya asumido; igualmente ocurrirá con el receptum arbitrii, pues no parece lógico aceptar que el pretor intentase agravar la responsabilidad del árbitro, ya que con el aumento del tráfico comercial, su intervención en aquellas situaciones en que se podía recurrir a él evitaba el sometimiento a un proceso ordinario, con lo cual, las relaciones comerciales controvertidas vendrían agilizadas. Hay que tener 
en cuenta que con este sistema el Estado seguía consevando su poder de intervención, aunque ahora lo hiciera de forma indirecta, estableciendo los requisitos necesarios para poder llevar a cabo un procedimiento arbitral, tanto por lo que respecta a las partes como al árbitro (que no ausume directamente la cualidad de órgano del Estado).

Distinto es el hecho de que el árbitro que no ha aceptado (el nombramiento) de manera expresa por medio del receptum pueda, si él y las partes lo desean, dar sentencia, quedando los sujetos obligados igualmente a ella, puesto que lo están en virtud del compromiso por el que acuerdan una poena en caso de no acatarla, siendo esto independiente del recibo del cargo por parte del árbitro; creemos que si no ha hecho tal aceptación no podía ser obligado.

El compromiso, por si mismo, tiene plena validez entre los sujetos que lo acuerdan. Hay, por tanto, que distinguir dos actos. Uno será el que realicen las partes entre sí, y el otro lo harán con el árbitro, una vez que se lo comunican y acepta expresamente, constituyendo esta aceptación el llamado receptum arbitrii; su responsabilidad se derivará del acuerdo por el que la acepta, ya que el pretor en su edicto viene a reconocer la protección de las partes que confían sus diferencias a un árbitro y si éste aceptó por medio de recipere.

\section{RESPONSABILIDAD DEL ARBITRO}

\subsection{Antes de la intervención del Pretor}

El recurso a un juicio arbitral fue una consecuencia derivada de las necesidades que iba imponiendo la vida práctica. En este sentido, parece lógico que este tipo de procedimiento haya precedido al procedimiento ordinario. Al pasar a vivir en núcleos de población, renunciando a la vida nómada y aislada, aparecen una serie de derechos y obligaciones, así como diferencias entre esos núcleos a propósito del cumplimiento de los mismos. En esta situación, era lógico el recurso a la condescendencia, manteniendose dispuestos a transigir en parte. Esto explica la capacidad de renuncia a los propios derechos, así como la compensación entre derechos y obligaciones. Tales formas abstractas se concretan luego en unos modos de hacer valer esos derechos que van desde la venganza privada a la legítima defensa y de la solución amistosa de los conflictos a la intervención de la autoridad pública.

En la base del receptum está la aplicación de la coacción basada en la mayor autoridad moral de la persona que decide la controversia. A esa persona se dirigían las partes litigantes, a causa de la confianza que les inspiraba. Ahora bien, el problema consiste en saber lo que acontecía en el caso de que el condenado no cumpliera el dictamen de esa tercera persona considerada imparcial. Probablemente la ejecución del mismo se encomendaba a la parte vencedora. Cuando esto no era posible, la comunidad política otorgaba un respaldo coactivo al árbitro, puediendo desempeñar esta función arbitral un persona dotada de imperium.

Por otra parte, parece evidente que se estableciera una serie de requisitos. En este sentido, la elección del tercero debería realizarse por el acuerdo común de las partes litigantes, las cuales se comprometerían a aceptar su decisión. De este modo, esa tercera persona quedaba legitimada para decidir sobre la controversia. 
$\mathrm{Al} \mathrm{remitir} \mathrm{sus} \mathrm{diferencias} \mathrm{al} \mathrm{árbitro,} \mathrm{las} \mathrm{partes} \mathrm{litigantes} \mathrm{pretendían} \mathrm{demostrar} \mathrm{su}$ derecho en un determinado conflicto y su buena fe, renunciando a la autodefensa. Matthiass entiende que el modo típico de aseguramiento habria sido lo que él llama la apuesta contractual, que no tendría como objeto sólo la constatación de las afirmaciones de las partes, sino que daba lugar a una serie de consecuencias derivadas de la misma. La intervención de la autoridad pública hizo que tal situación de hecho pasara a ser una relación jurídica. La cantidad de dinero apostada dejaba de ser una mera "satisfacción" al vencedor y pasaba a ser una indemnización propiamente dicha (24).

Probablemente, antes de la aparición de la coercitio pretoria sólo recaía sobre el árbitro una obligación moral que se derivaba de la fides que le habían otorgado los titigantes al confiarle la solución de su conflicto. Pero no puede demostrarse con rigor que el receptum se considera como contrato en la época anterior al Edicto, aunque este mismo autor piensa que el receptum debe entenderse como el contrato de las partes con el árbitro en el que éste promete dictar sentecia.

Según él, habría dos contratos, aunque de naturaleza distinta, ya que los litigantes que figuraban como partes contrapuestas en el contrato de compromissum, debían aparecer juntos en el receptum, ya que en éste las partes están vinculadas y actúan de común acuerdo. Esta estructura arcaica del receptum necesariamente debía ser tenida en cuenta por el pretor en el momento de redactar su edictum (25). Sin embargo, debe tenerse presente que las partes no disponían de medios para forzar al árbitro a dictar sentencia. En caso de que no lo hiciera, su recurso consistiría en acudir a otro árbitro o a un juez ordinario, teniendo en cuenta que la ausencia de una forma contractual determinada hacía imposible el ejercicio de una acción para exigir el cumplimiento.

\subsection{El Edicto del pretor y la fuerza coactiva del arbitraje.}

De igual modo que la intervención del pretor tuvo una influencia en las demás instituciones, en el arbitraje es también evidente su influjo, en cuanto dotó a esta institución de fuerza coactiva. Hay que tener presente, por otra parte, que el pretor no modificó esencialmente el receptum, que continúa teniendo el carácter contractual que le caracterizaba y que supone que se obligaba a decidir una controversia que le habían deferido libremente las partes litigantes. Ese receptum supone que el árbitro tiene una relación con ambas partes, y no sólo con una de ellas. El hecho de asumir la obligación de decidir partiendo del compromissum entre las partes, obliga al árbitro a pronunciarse sobre el asunto que es objeto de la relación jurídica que está en litigio. Hay que observar, por último, que no es posible encontrar en las fuentes datos precisos a propósito de la competencia objetiva del árbitro o de la categoría contractual a que podía ser asimilado el receptum. En cualquier caso, el hecho de que las partes acudieran a un árbitro, pone de manifiesto la existencia de una desconfianza, más o menos difusa, en los tribunales ordinarios de justicia.

A fin de concretar las modificaciones que introdujo el pretor en el receptum, debemos partir del hecho de que el edicto supuso un intento importante de afrontar el principal problema que se presentaba y que no era otro que la ausencia de unos 
medios para coaccionar al árbitro. La rubrica del Edicto se expresaba en estos términos: ait praetor: quia arbitrium pecunia compromissa receperit (26).

La coacción del pretor se manifiesta de diversos modos. En unos casos, prohibiendo al árbitro dictar sentencia; en otros, obligando al árbitro a dictar esa sentencia; finalmente, sancionando al árbitro por no dictarla. Tal actuación del pretor tiene lugar generalmente a instancia de la partes. Pero en alguna ocasión puede decidirse él a actuar, sin que se lo soliciten:

Iulianus indistincte scribit: si per errorem de famoso delicto ad arbitrum itum est, vel de la re, de qua publicum iudicium sit constitutum, veluti de adulteriis sicariis et similibus, vetare debet praetor sententiam dicere nec dare dictae exsecutionem (27).

La sanción al árbitro por incumplimiento del receptum ha planteado especiales dificultades en la doctrina, a causa de las dudas existentes a propósito de la naturaleza jurídica de esta institución, esto es, de la obligación que tiene el árbitro de dictar una sentencia que resuelva la controversia. Weizsäcker (28) entre otros, afirma la naturaleza contractual del receptum, si bien reconoce que se trata de un contrato sui generis. Igualmente Matthiass entiende que el Edicto, al acentuar el carácter publicístico del receptum, puso fin a la discusión acerca de la naturaleza contractual del mismo. En cualquier caso, y como ocurriría con Weizsäcker, se niega la posibilidad se que se tratara de un supuesto de locatio-conductio.

En general, la doctrina se ha limitado a señalar, de forma genérica, la naturaleza contractual del receptum, llegándose a hablar en algún caso de un "medio contrato" sin forma (29).

Según el punto de vista mantenido por Albanese (30), los recepta eran negocios fundados en el simple consentimiento, por el que una parte asumía, frente a la otra, una obligación de un resultado determinado.

Entiendo que no está suficientemente fundado el criterio que tiende a considerar al receptum como un contrato. En particular, no se trataría de un contrato de la misma naturaleza, por ejemplo, que la locatio-conductio. El orden del receptum arbitrii pudo haber sido la recepción por parte del árbitro de la cantidad de dinero, o del objeto constituido como apuesta, obligándose a guardarlo y restituirlo a la parte vencedora. Este hecho explica por qué en un principio se consideraba la inclusión de una pena que asegurara el cumplimiento de la obligación asumida por el árbitro.

En algunos casos se ha querido relacionar la obligación del árbitro (en virtud del receptum) con la del iudex (como consecuencia del ius iudicandi). La Pira (31) exagera ese paralelismo, olvidando que la sentencia del árbitro no produce el efecto de res iudicata, debiéndose esto a que el iussum iudicandi supone un respaldo oficial del cual carece el receptum. Hay que tener en cuenta, por otra parte, que el iussum iudicandi estaba expresamente incluido en la fórmula. En la Tabula Pompeiana 344 se lee:

(Si par) et C(caium) Marcium (Satur) ninum/. [C(aio)] Sulpicio Cinnam (OHS) I MM/ (d) are oportere $q(u a)$ [d(e) agiltur/ C(aius) Blossius Celadus (i)ude[x C(aium)] / Marcium Satu (rn)ium HS (...) 
CCI / [C(aio) Su] Ipicio Cinnam (o co)ndemnato,] si non paret absolvito./ Iudicare iussit P(ublius) (C)ass (i)u(s) (P)riscus Ilvir. (32).

Es importante tener presente la posibilidad de que fuera utilizada la sanción a los otros tipos de recepta al receptum arbitrii. Entiendo que tal extensión analógica no es posible. En efecto, la intervención del pretor no tenía idéntico significado en los distintos supuestos. Piénsese, por ejemplo, en el pasaje siguiente:

Ait praetor: Nautae caupones stabularii quod cuiusque salvum fore receperint nisi restituent, in eos iudicium dabo (33).

Lenel reconstruye de la siguiente forma la rúbrica del Edicto, en el supuesto del receptum arbitri:

Qui arbitrium pecunia compromissa receperit, eum sententiam dicere cogam (34).

La coacción ejercida por el pretor en el caso de los nautae, caupones y stabularii se concreta en la expresión iudicium dabo, mientras que en el caso del árbitro se limita a un genérico cogere. La primera expresión hace referencia, con probabilidad, a la concesión de una actio (actio ex recepto), mientras que de la segunda no puede extraerse una conclusión precisa, en cuanto que cogere puede hacer referencia a cualquier tipo de coercitio de los que dispone el magistrado. En cualquier caso parece apoyar esta idea el siguiente fragmento de Paulo:

Nam magistratu superiore aut pari imperio nullo modo possunt cogi: nec interest ante an in ipso magistratu arbitrium susceperint. Inferiores possunt cogi (35).

De acuerdo, con el texto, Paulo entiende que no es posible obligar a los magistrados de igual o superior imperium a dictar sentencia. Esto significa, a mi entender, que la coercitio, en el caso del arbitraje, no se realizaría por medio de una actio sino por procedimientos extraprocesales. Piensese, por ejemplo, en este pasaje de Ulpiano:

...Cogenda igitur erit remediis praetoris et in ius venire et, si venit, respondere: pignoraque eius capienda et distrahenda, si contemnat, vel multius coercenda (36).

Por lo que se refiere al modo de exigir el cumplimiento del árbrito que acepta, algunos autores son partidarios de que el pretor concedía a las partes una acito in factum contra el árbitro que no daba sentencia (37).

No existen fuentes que nos permitan asegurar categóricamente la existencia de acción alguna contra el árbitro incumplidor. Cuesta creer que esto se pudiera haber dado sin que en ningún momento el Digesto la mencione, aunque fuese de manera indirecta.

Paricio afirma que "durante algún tiempo le pareció que un fragmento de Calistrato quizá podía implícitamente estar atestiguando la existencia de una acción contra el árbitro"; pero luego añade que "este fragmento tampoco sirve para demostrarlo" (38).

El texto al que se refiere al autor en el siguiente: 
Cum lege Julia cautum sit, ne minor viginti annis iudicare cogatur, nemini licere minorem viginte annis compromissarium iudicem eligere: ideoque poena ex sententia eius nullo modo committitur. Maiori tamen viginti annis, si minor viginti quinque annis sit, ex hac causa succurrendum, si temere auditorium receperit, multi dixerunt (39).

En él, el jurista nos habla de que sería nula la sentencia emitida por un menor de veinte años, pues no se incurre en la pena de la estipulación, ya que a nadie le es lícito elegir como juez compromisario al menor de veinte años. Pero el fragmento segundo añade que se ha de socorrer al menor de vienticinco años cuando hubiera asumido temerariamente el juicio.

Añade el autor que un texto similar para descubrir esa acción se encuentra en D. $2,13,1,5$, que hace referencia al hecho de que procede una actio in factum contra el demandante que no ha hecho la comunicación:

Eis, qui ob aetatem vel rusticitatem vel ob sexum lapsi non ediderunt vel ex alia iusta causa, subvenietur.

En principio, el autor acepta que se hable de subvenire en D. 2, 13, 1, 5 y sucurrere en D. $4,8,41$, pero añade que se trata de verbos sinónimos y que quizás esto da motivo a creer que cuando en el título $4^{\circ}$ se está hablando de proteger (sucurrere) al comprendido entre veinte y veinticinco años, que ha asumido un arbitraje temerariamente, se deseaba protegerle frente a la posibilidad de que alguien ejercitase una acción sobre él.

Esta interpretación va mucho más allá del texto, pues a lo único a lo que parece referirse el jurista, como dice el autor, "es que la Lex Julia que protege al menor de veinte años habría de extenderse también al menor de veinticinco".

El problema que se plantea sobre la validez de la sentencia emitida por un juez que aun no ha alcanzado la edad de veinticinco años, pero es mayor de veinte, parece se traslada a la dada por un arbiter ex compromisso que se encuentra en la misma situación de edad; por ello parece lógico que algunos dijeran que se debía socorrer al que se encontraba entre veinte y veinticinco años, pero que esa protección consistía en que el pretor no le obligaría a dar sentencia.

Si esto es así, parece congruente que el texto del D. 4, 8, 31 no serviría para fundamentar una acción contra el árbitro, y si prescindimos de este texto, no se encuentra otro que pueda servir de ayuda.

Como decíamos anteriormente, es difícil comprender que sólo pudiera ser obligado por el pretor, a través de una multa o embargo, el árbitro que no dictaba la sentencia. Porque si bien esto era perjudicial para el árbitro que tenía que pagar, no quedaban con ello las partes satisfechas, ya que si ellos concertaron un compromiso arbitral es porque el fin que perseguían era que se diese una solución a su controversia.

No queda claro, pues, en este aspecto, que no existiese algún medio que pudiera ser utilizado por las partes que habían sido dañadas ante la falta de cumplimiento del árbitro.

$\mathrm{Si}$, como sabemos, el deber esencial del juez es dar sentencia (40) y cuando no 
actúa así incurre en responsabilidad (41) y se considera que había frustrado para siempre el litigio y lo hacía suyo (litem suam faciebat) ya que se subrogaban en la posición del demandado y se podía ejercitar contra él la actio adversus iudicem qui litem suam fecit, pues había ocasionado perjuicio al demandante, ya que la acción que se la había concedido contra el demandado había sido consumida en la litis constestatio, cuando es el árbitro quién no emite la sentencia ¿no está causando un evidente perjuicio al demandante?.

Es evidente el interés que tiene la reflexión sobre esta situación arbitral, ante el hecho de que si bien cuando era un arbiter ex compromisso no se producía este problema, ya que la acción no se agotaba siempre y cuando el asunto que se ventilaba ante el árbitro, venía protegido de acción perpetua y no se cerraba la posibilidad de acudir a un juicio ordinario, el demandante siempre podía someter su controversia a él cuando el árbitro no hubiera dictado la sentencia en el plazo establecido.

Sin embargo, puede darse también el caso de que el asunto que se litigase fuera de aquellos que venían protegidos por una acción anual, como ocurría con las honorarias, en caso de que las partes no hubieran tenido la cautela suficiente para otorgar al árbitro en el compromiso un plazo inferior para que así, en el caso de no cumplir, les quedara tiempo para acudir al juicio ordinario. ¿Qué ocurriría en este caso?.

Algunos consideran que la única solución posible sería que el magistrado, «causa cognita», concediera al demandante frustrado una acción contra el árbitro, semejante a la actio in factum que procedía contra el juez que hizo suyo el litigio siendo una acción decretal, no edictal.

También cabe, independiente de la acción con que viniera protegida la cuestión litigiosa, que, como hemos dicho anteriormente, si bien el compromiso no suponía una renuncia tácita de acudir a un proceso, si que era posible que las partes lo concertasen.

Parece lógico que, en este caso, el árbitro producía el mismo daño al demandante que el que ocasionaba el juez ordinario que no dictaba sentencia. En este supuesto, el pretor concedería contra el árbitro que no cumplió, una acción análoga a la actio adversus iudicem qui litem suam fecit, y que quedaría a discreción del magistrado.

Esta tesis, expuesta por Paricio, parece la más acertada, ya que no podían quedar indefensas las partes que, habiendo elegido resolver su litigio a través de un árbitro, cuando éste, por su incumplimiento, les podía ocasionar un perjuicio semejante al que ocasionaba el juez que se comportaba igualmente de manera incorrecta en su función. Y aunque no sabemos a ciencia cierta qué acción sería concedida (42), pues las fuentes no nos dan cuenta de ella y lo único que sabemos es que verdaderamente el edicto no la contemplaba, eso también es lógico teniendo en cuenta que aquellas situaciones que el pretor consideraba injustas quedaban sometidas sencillamente a su discreción y las concedería cuando él estimase que la situación lo requería.

El pretor, con su apoyo a este medio, pretende que el arbitraje sea un complemento de la administración ordinaria de justicia, más que una sustitución de la misma. 
Sólo posteriormente nos encontramos con textos de Justiniano en que reforma esto, dedicando atención especial a la institución del tribunal arbitral, e introduciendo por primera vez una verdadera actio in factum para exigir la sentencia de los árbitros, cuando las partes así lo hubieran expresamente acordado (Caudum homologatum).

Esta sentencia arbitral no era res iudicata, pues siempre podría recurrirse a un proceso ordinario: pero se otorgaba al demandado una exceptio y al demandante una actio in factum, lo que suponía una garantía estatal directa y no la necesidad de que las partes tuvieran que asegurarla, mediante la estipulación de una pena en el compromiso.

Las disposiciones son bastante complicadas: si las partes litigantes han elegido bajo juramento al árbitro, y si éste también se ha comprometido por juramento a dictar una sentencia justa (debiéndose demostrar estos hechos por medio de las firmas de las partes, de testificación documental de fedatarios oficiales o de las actas de arbiter), o bien si ambas partes litigantes, antes o después de dictar sentencia, se comprometen mediante juramento a respetarla; o finalmente, es el árbitro sólo el que ha hecho promesa por solicitud de las partes de emitir bajo juramento una sentencia justa, entonces liceat vel in factum vel conditionem ex lege vel ...rem utilem instituere (43).

Esta forma de proteger y asegurar la sentencia fue luego anulada por Justiniano, en el año 539 (44), debido a los serios inconvenientes que presentaba y a los frecuentes perjuicios que se daban.

Se mantuvo la disposición de que el reconocimiento de la sentencia emitida, ya fuese oralmente (aunque no en forma estipulada) o por escrito, o incluso tácitamente, al abstenerse en el plazo de diez días a impugnarla, otorgaba al acusado una exceptio veluti pacti y al demandante una acito in factum.

\section{NOTAS}

(1).- CICERON, Pro Rosc., IV, 12: compromissum faceris, arbitrium sumpseris; Alf, 7 , D. $4,8,50$ : arbiter ex sumptus...

(2).- D. $4,8,31$.

(3).- WLASSAK, Art. Arbiter n. I, tomo III, pág. 408-10 y Art. Arbitrium n. 1, pág. 412 ss.

(4).- WEIZSAECKER, Das römische Schiedsrichter amt unter Vergleichung mit dem officium iudicis, Tubigen, 1879.

(5).- D. 4, 8, 13, 2.

(6).- C. 1., 3, 1, 14, 1 .

(7).- Contra esto WEIZSACKER, op. cit., p. 63.

(8).- WEIZSACKER, op. cit., p. 65.

(9).- MATTHIAS, Die Entwicklung..., ed. cit., p. 54 y ss. 
(10).- Nos ha llegado una sentencia emitida en el s. I d. C. de un arbiter ex compromisso sobre un asunto de demarcación entre la Comunidad Histonium y un particular.

(11).- MOMMSEN, Rev. Jurid. I, 376, 83.

(12).- MATTHIAS, I, 29; DE RUGIERO, Dio. epig., I, 1615.

(13).- WENGER, Receptum arbitrii, en P.W., p. 363.

(14).- D. $4,8,3,1$.

(15).- D. $4,8,32,6$.

(16).- D. $4,8,32,7$.

(17).- D. $4,8,32,5$.

(18).- D. $4,8,32,10$.

(19).- C. I., II, 46, 3, 1.

(20).- MATTHIAS, op. cit. p. 29.

(21).- PARTSCH, en op. cit., la sitúa dos siglos a. de C.

(22).- LENEL, Ed. Pep. 2, 129.

(23).- D. $4,8,32,4$ y $15,16$.

(24).- MATTHIASS, Die Entwicklung..., op. cit., p. 19-20.

(25).- MATTHIASS, Die Entwicklung..., op. cit., p. 19-20.

(26).- D. 4, 8, 3, 2.

(27).- D. $4,8,32,6$.

(28).- C. WEIZSÄCKER. Das Römische Schiedsrichteramt..., ed. cit., p. 65. Por su parte WENGER (Receptum arbitri), en P.W. I, P. 358 ss., intenta encuadrarlo entre las operae liberales, posición que es rechazada por VISKY (Geistige Arbeit und die "Artes liberales" in den Quellen des römischen Recht, Budapest, 1977). Más recientemente, ha seguido este mismo planteamiento W. WALDSTERIN (Operae Lebertorum. Untersuchungen zur Dienstpflicht Freigelassener, Stuttgart, 1986).

(29).- A. PER NICE, Parerga, en SZ, 20 (1900). Este autor, al referirse al significado de receptum, entiende que éste no es la aceptación de una cosa, ya que lo que se acepta en el receptum arbitri es el dictar sentencia (ib. p. 137).

(30).- B. ALBANESE, Gli atti negoziali nel Diritto Privato Romano, Palermo, 1932, p. 155.

(31).- G. LA PIRA, Compromissum..., ed. cit, p. 219.

(32).- Cfr. la transcripción de L. BOVE (Documenti processuali dalle Tabulae Pompeianae di Murecine, Nápoles, 1979, p. 106).

(33).- D. $4,9,1$ pr.

(34).- D. 4, 8, 3, 2; este pasaje se completaría, según Lenel, con D. 4, 8, 15.

(35).- D. $4,8,4$.

(36).- D. $25,4,1,3$. El propio Paulo se expresa también de forma parecida en otro pasaje: Si arbiter sese celare temptaverit, praetor eum investigare debet, etsi diu non paruerit, multa adversus eum dicenda est (D. $4,8,32,12$ ).

(37).- SCHULZ fue partidario durante algún tiempo de la existencia de esta acción contra el árbitro incumplidor en I principii, p. 195. D'ORS en DPR.; pero mientras en ediciones anteriores a la de 1983 mantenía en vía de hipótesis que el receptum arbitrii daba lugar a una actio in factum contra el árbitro que no cumple el encargo, en la edición posterior a la fecha señalada, indica que el receptum arbitrii, quizá al igual que los otros recepta, daría lugar a una actio in factum. 
(38).- PARICIO, op. cit., p. 300.

(39).- D. $4,8,41$.

(40).- Jul. 5, D. 5, 1, 74; Ulp. 51 ad Sab. D., 42, 1, 55.

(41).- CREMADES Y PARICIO, en "La responsabilidad del juez en el Derecho Romano Clásico", dicen que la nueva tesis d'orsiana consiste en señalar que un juez litem suam facit cuando no da sentencia, a lo que quedaría equiparado el darla fuera de los límites de la fórmula, pues tal sentencia sería nula y equivaldría a ausencia de ella".

(42).- PARICIO, art. cit., que dice: "En cierta manera se podría hablar de una acción decretal y «ficticia» con ficción de que el arbiter ex compromisso era juez ordinario y había hecho suyo el litigio, pero ello no sería exacto pues una acción ficticia se basa siempre en una acción in ius. En nuestro caso, simplemente se trataría de una acción análoga a la actio adversus iudicem qui litem suam fecit que no tenía fórmula in ius sino in factum.

(43).- C. I. 4, 5, 5, 2; Nov. 82, 11.

(44).- Nov. Iust. 82, 11. 


\section{APROXIMACION AL NACIMIENTO DE LA CUESTION RELIGIOSA}

\section{NIEVES MONTESINOS SANCHEZ}

Pfra. Derecho Eclesiástico del Estado

La Constitución Española de 1978 marca un hito fundamental en materia de Relaciones Iglesia-Estado en la historia del constitucionalismo español, y esto es así porque supone una novedad digna de mención, la clara intención de presentarse como superadora de la cuestión religiosa, que dividió a los españoles más radicales, de entre aquellos que fueron testigos de nuestra historia contemporánea, en dos bandos que parecieron ireconciliables.

La cuestión religiosa tuvo cabida en todos los textos constitucionales que vieron la luz, e incluso los que no la vieron a lo largo del siglo XIX y principios del XX.

En efecto, las Constituciones han sido varias y variadas, quizá demasiadas, pero ayudan a conocer la época que nacen.

Así a la Constitución de 1808 sigue la Constitución de 1812 que con derogaciones y proclamaciones la encontraremos hasta 1837 , y posteriormente en período relativamente breve, conoceremos cuatro textos constitucionales, a saber, el Estatuto Real de 1834, la Constitución de 1837, la Constitución de 1845 y la Constitución no promulgada de 1856 , sin contar con los diversos proyectos que no llegaron a convertirse en texto constitucional, pese a que alguno de ellos, tenían entidad e importancia suficientes, pero la coyuntura socio-política del pais lo impidió.

La Revolución de Septiembre de 1868 supondrá un nuevo cambio constitucional, la Constitución de 1869, a la que seguirá el proyecto de constitución federal de 1873. Y una vez producida la Restauración, resultará obligado el señalar la Constitución de 1876, fundamentalmente porque estamos en presencia de la de más dilatada vigencia, ya que se aplicará hasta 1923, momento en que se implanta la dictadura de Primo de Rivera (Proyecto de 1929) y posteriormente al final de la dictadura hasta el advenimiento de la II República. El último de los textos constitucionales, la Constitución de la II República de 1931, significará el tratamiento más radical conocido en nuestro país de la cuestión religiosa y por ende de las relaciones entre la Iglesia y el estado.

Quizá por ello puedan merecer la pena estas páginas, como intento de aproximacion al nacimiento de la cuestión religiosa.

\section{La Constitución de Bayona}

LEl primer texto constitucional, el Estatuto de Bayona de 1808 recoge una clara declaración de confesionalidad, la cual es consecuencia por un lado de la condición impuesta por Carlos IV para abdicar (mantener la confesionalidad católica), y por 
otro de la política de Napoleón de ganarse el apoyo de la Iglesia y servirse de ella. (1).

José Bonaparte al aceptar la corona de España declaraba en Decreto de 10 de junio de 1808: "La conservación de la santa religión de nuestros mayores en el estado próspero en que la encontramos... serán nuestros primeros deberes".

Varios fueron los proyectos presentados hasta llegar a la formulación definitiva que recoge el Estatuto de Bayona de la cuestión religiosa. Igualmente distinta fue la ubicación asignada al tema religioso en cada uno de los proyectos. El primer proyecto se ocupa de la cuestión religiosa en el artículo 47, que establecía:

"La religión católica, Apostólica, Romana es la sóla cuyo culto puede ser tolerado en España". Parece ser que la importancia del tema en cuestión, hizo cambiar el lugar en un principio asignado al mismo, y así, el segundo proyecto aborda la cuestión religiosa en el artículo $1^{2}$, en el cual se decía: "La religión Catòlica, Apostólica, Romana es en España la religión dominante y única, ninguna otra será toleradas".

La confesionalidad apuntada en el primer proyecto se vuelve más rotunda y tajante en el segundo, e incluso, esta última formulación es más terminante que la definitiva.

El 15 de junio de 1808, la Junta de Bayona se reunió para examinar y aprobar el estatuto constitucional. Estaba formada por nobles, militares, clérigos y funcionarios del antiguo régimen, lo cual nos permite considerarla como una junta claramente conservadora. (3).

La proclamación del Estatuto de Bayona se produce el 6 de julio de 1808 y en su Título I, artículo 1ำ (y único), se establece:"La religión Católica, Apostólica y Romana en España y en todas las posesiones españolas, será la religión del Rey y de la Nación y no se permitirá ninguna otra". (4).

En consecuencia, el texto constituciuonal regula la cuestión religiosa, decantándose a favor de una clara formulación de confesionalidad, con un significado casi idéntico al que dicho término tuvo en su origen, ya que se reconoce a nivel constitucional que la religión católica será la del Rey y de la Nación, lo cual nos hace trasladarnos a principios ya lejanos como el de "cuius Regio eius et religio".

Del mismo modo, queda establecida la intolerancia más absoluta hacia las restantes religiones, sin ni tan siquiera distinguir como lo harán otros textos constitucionales entre ejercicio público o privado.

Ahora bien, si la declaración de confesionalidad no ofrece duda, quizá se trata de una fórmula realizada con la intención de satisfacer al pueblo español y alejar los recelos antireligiosos que acompañaban al rey Francés. (5). Esta tesis podría verse avalada por los siguientes argumentos:

En los acuerdos pactados por la Constitución de Madrid de 4 de diciembre de 1808 se estipuló: "La conservación de la religión católica, apostólica y romana sin tolerancia de otra alguna, así como la conservación de las vidas, derechos y propiedades de los eclesiásticos seculares y regulares, conservándose el respeto debido a 
los templos conforme a nuestras leyes" (6). En este pacto se sigue la línea establecida en el texto constitucional.

En segundo lugar, esta linea de marcada confesionalidad se quiebra fácil y rapidamente con las reformas religiosas que retiradas en un principio de la Constitución aparecen ahora. El Santo Oficio queda suprimido y sus bienes incorporados a la Corona. Los conventos quedaron reducidos con el pretexto de que su número era excesivo y perjudicial a la prosperidad del Estado (Decretos de Chamartín).

Por último, podemos resumir los principios rectores de la política religiosa de la época una vez establecidos los frenos necesarios de la Religión, que era considerada constitucionalmente como de la Nación, en: a) captación del clero y de los frailes, b) reducción del personal eclesiástico, c) supresión de regulares, d) desamortización, e) apoyo al clero parroquial (ya que cuando el rey José vuelve a entrar en Madrid busca en la religión la legitimación de su poder), f) usurpación de la jurisdicción eclesiástica. Por todo ello, los recelos antirreligiosos a los que antes hacíamos referencia, quizá no iban tan desencaminados.

Siguiendo el íter constitucional, nos encontraríamos con la Constitución de 1812, pero no podemos adentrarnos en ella sin hacer por lo menos mención del proyecto de constitución presentado por D. Alvaro Flórez Estrada ante la Junta Central de Sevilla el 1 de noviembre de 1809. La intención de dicho proyecto por lo que afecta a la cuestión religiosa era diametralmente opuesta a la que quedó plasmada en el texto del Estatuto de Bayona; en él se pretende el establecimiento de la libertad de cultos, y se proponía que ningún ciudadano fuese incomodado en su religión "sea la que fuera" (7).

Las tentativas librecultistas no llegaron a verse recogidas en texto constitucional, porque el proyecto quedó en eso, en proyecto, y en el texto constitucional del 12 tampoco tendrían cabida.

\section{La Constitución de Cádiz}

La Constitución de Cádiz es claro reflejo de la situación socio-política por la que atraviesa el pais en aquellos momentos, incluso es un texto que expresa la historia española del siglo XIX.

Y si tal afirmación puede ser válida en términos generales, el tratamiento que las Cortes de Cádiz dan a la cuestión religiosa es todavía más significativo y su resultado final fue el de una reforma a medio camino que pareció corta a los innovadores y abusiva a los liberales. (8).

La Constitución de 1812, incluso en mayor medida que la de Bayona de 1808 , supone una fórmula de compromiso. No encontramos en la historia constitucional española, ni en constituciones de otros países, una declaración con el mayor rango normativo que suponga una profesión de religiosidad tan palmaria. De no ser así, no sería fácil interpretar el texto constitucional, no tendría sentido el encabezamiento, la llamativa afirmación de confesionalidad, la prohibición de la libertad de conciencia... sobre todo teniendo en cuenta que estamos en presencia de una constitución que nace con un marcado espíritu liberal. (9). 
El texto del artículo 12 de la Constitución de Cádiz no nació en los térrminos en que posteriormente quedó plasmado y hoy conocemos. En un primer momento el texto del artículo era "La Nación española profesa la religión católica, apostólica, romana, única verdadera con exclusión de cualquier otra". (10).

Cuando en diciembre de 1811, exactamente el 2 de diciembre, empieza la discusión sobre el precepto en el que quedará, de manera fundamental, regulado el tema religioso, no se pueden dejar de tener presentes las afirmaciones que se habían vertido en el Discurso Preliminar: "La declaración solemne y auténtica de que la religión católica, apostólica, romana es, y será siempre, la religión de la nación española con exclusión de cualquier otra ha debido ocupar en la ley fundamental del Estado un lugar preeminente cual corresponde a la grandeza y sublimidad de su objeto". (11).

Pese a que en ocasiones se haya afirmado lo contrario, parece ser que las Cortes de Cádiz no tuvieron nada de impías, la tercera parte aproximadamente de sus componentes pertenecían al estado eclesiástico (12) y comenzaban sus sesiones con la misa del Espíritu Santo. Según afirma REVUELTA "Los diputados están plenamente convencidos de que sin religión no es posible la permanencia de una sociedad justa, libre y ordenada y de que es precisamente la religión católica, la que mejor se acomoda a un gobierno ilustrado". (13).

A la vista de tales observaciones no es de extrañar que el texto gaditano en el que queda recogida la cuestión religiosa quedará como sigue en su artículo 12: "La religión de la Nación española es y será perpetuamente la católica, apostólica, romana, única verdadera. La Nación la protege por leyes sabias y justas y prohibe el ejercicio de cualquier otra" (14). E incluso llegó a sugerirse por el presidente que el texto fuera votado por aclamación (situación a la que no hubo lugar).

De la observación y análisis del texto legal, y teniendo en cuenta el desarrollo posterior de los acontecimientos y disposiciones legales se podrían hacer las siguientes matizaciones:

Nos encontramos ante una regulación de la cuestión religiosa por medio de una declaración clara de confesionalidad, ya que no es necesario deducirla del tenor literal del texto sino que en el mismo se establece expresamente: "La religión de la Nación española es y será perpétuamente la católica, apostólica, romana".

Ha desaparecido la fórmula utilizada en la Constitución de Bayona en la que se hacía referencia tanto a la Nación como al Rey. Se acoge pues la confesionalidad como religión nacional sin diferenciar entre rey y ciudadanos.

La admisión de la religión católica como la de la Nación no queda únicamente ahí, sino que además esta confesionalidad es calificada y especificada como “...única y verdadera...". No es simplemente una declaración de confesionalidad, sino una confesionalidad dogmática, ya que los padres de la patria valoran a la religión de verdadera y única, lo que no volverenos a encontrar en ningún otro de los textos constitucionales, excepción hecha de la Ley de Principios del Movimiento Nacional, en su principio II; con la particularidad de que no se trata de un texto constitucional, si bien forma parte del cuerpo legal de mayor rango jurídico vigente en el período Franquista. 
Además, en el precepto legal que analizamos, se plasman a renglón seguido dos afirmaciones yuxtapuestas, que no necesariamente complementarias, a saber, de una parte "La Nación la protege con leyes sabias y justas", y. de otra "... prohibe el jercicio de cualquier otra". La primera de ellas va a dar lugar en el devenir de los acontecimientos a la ingerencia e intervención ya directa, ya indirecta, del estado en los asuntos y materias que en principio son competencia exclusiva de la Iglesia, la cual, recordemos, cuenta con un reconocimiento y respaldo constitucional, cuando menos a nivel formal. Esto va a remontarnos a las mejores épocas regalistas (15).

La segunda, nos sitúa en igualdad de condiciones por lo que respecto a las restantes confesiones que el texto de Bayona, es decir, sigue defendiéndose la tesis de la intolerencia hacia las demás religiones, no distinguiéndose tampoco ahora entre el culto privado o público.

Como resulta evidente de lo expuesto, es el artículo 12 el que en el texto de Cádiz define la cuestión religiosa y en consecuencia establece el marco dentro del cual deben desarrollarse por imperativo constitucional las relaciones entre la Iglesia y el Estado. Ahora bien, existen otros artículos que guardan una clara relación con el tema, alguno de los cuales abundan en el espíritu confesional (16) y otros lo desarrollan o matizan y en consecuencia no aportan nada especialmente significativo, por ello no entramos en el estudio pormenorizado de los mismos.

Por contra, sí parece representativo tanto del clima y composición de las Cortes en aquel momento, como de la fuerza del sentimiento religioso tradicional y en suma de la importancia de la cuestión religiosa, la invocación a la Trinidad con la que comienza tan importante Constitución que, nunca mejor dicho, rezaba así: "En el nombre de Dios Todopoderoso, Padre, Hijo y Espíritu Santo, autor y supremo legislador de la sociedad". En este encabezamiento palpita una seria confesión de fe y una afirmación de la ética social cristiana que pone en Dios la fuente última del poder y de la soberanía, así como el origen y fundamento de la sociedad (17). De modo semejante el profesor SANCHEZ AGESTA mantendrá que "éstos términos no son una fórmula ritual, sino que tienen un valor preciso y medido por los propios constituyentes: considerar a Dios como fundador de la sociedad y su supremo legislador, con lo que queda definido el origen divino de la sociedad y del poder" (18).

Ciertamente esta invocación trinitaria parece estar en contradicción con el espíritu liberal que animaba a gran parte de los legisladores gaditanos, los cuales llegaron a ceder tan solemnemente la suprema potestad de legislar la sociedad.

Incluso si seguimos el Diario de Sesiones descubriremos testimonios importantes que aluden a la invocación que nos ocupa, y de entre ellos cabe destacar los de algunos diputados que pretendian se hiciese una protestación más solemne de la fe católica, o que esta se ampliara, y por supuesto las reflexiones realizadas por aquellos que consideraban totalmente oportuna e importante la invocación referida por cuanto se mantiene en la línea del más puro sentimiento religioso tradicional de la Nación, del que debe darse testimonio al mundo entero. (19)

Por todo ello, y en cuanto que quedó plasmado en el texto constitucional de 1812 , podríamos concluir sosteniendo que no fue el texto de la constitución especial 
o marcadamente revolucionario por lo que respecta a sus principios políticos, ahora bien, si fue impecablemente confesional en el sentido religioso. (20)

Como se ha afirmado en múltiples ocasiones, el más grave legado que las Cortes de Cádiz dejaron a las posteriores legislaciones del siglo fue la llamada cuestión religiosa. $Y$ aunque pueda defenderse la exactitud de esta tesis, parece del mismo modo cierto que no fueron las prescripciones constitucionales del texto del 12 , las que provocaron la cuestión religiosa, e igualmente puede asegurarse que quienes creyeron que con el artículo 12 ya citado quedaban garantizados la inalterabilidad de los principios y privilegios eclesiásticos se engañaban lastimosamente (21).

Si andamos sobre nuestros pasos, podremos recordar que esta Constitución recoge una fórmula de compromiso, fruto incuestionable de las circunstancias históricas, y no del espíritu que inspiraba y animaba a los liberales gaditanos, y en dicha fórmula quedó encerrada la posibilidad de que la unidad católica, dogmatizada y defendida constitucionalmente fuera principio constitucional que estaba destinado a ser incumplido con mayor o menor facilidad o habilidad. Siempre, teniendo como base los términos constitucionales en los que insistiendo en la confesionalidad ya declarada se decía: “...La Nación la protege por leyes sabias y justas...". Y en nuestra opinión las leyes que emanaron de las Cortes no supusieron en principio una protección o defensa de la confesionalidad constitucionalizada, siendo en consecuencia del conjunto de lo expuesto del que derivó la cuestión religiosa.

ARGÜELLES lo explica claramente tomando como punto de apoyo el contrasentido de dos términos teóricamente enfrentados, intolerancia - espiritu liberal, destinados ahora a entenderse porque así lo aconseja la estrategia constitucional: "En el punto de la religión se cometió un error grave, funesto, origen de grandes males, pero inevitable. Se consagraba de nuevo la intolerancia religiosa, y lo peor era que, por decirlo así, a sabiendas de muchos que aprobaron con el más profundo dolor el artículo 12. Para establecer la doctrina contraria hubiera sido necesario luchar frente a frente con toda la violencia y furia teológica del clero, cuyos efectos demasiado experimentados estaban ya, así dentro como fuera de las Cortes. Por eso se creyó prudente dejar al tiempo, al progreso de la ilustración, a la docta controversia de los escritores, a las reformas sucesivas y graduales de las Cortes que se corrigiese, sin lucha ni escándalo, el espíritu intolerante que predominaba en una gran parte del estado eclesiático." (22)

En efecto, con la legislación posterior se consiguió en parte lo que no habría sido posible en el precepto constitiucional y así, sobre la base de una religión tradicional venerada en toda su pureza y con el pretexto de protegerla, los innovadores lograron implantar la táctica regalista de prevalencia estatal sobre la Iglesia.

Y si observamos el conjunto de las disposiciones legislativas referidas a materias eclesiásticas a lo largo de 1811, 1812 y 1813, encontraremos en ellas una síntesis de tendencias opuestas.

De las Cortes brotaron multitud de disposiciones (23) que regularon los fondos de obras pías, la retribución de clérigos, la provisión de beneficios, la enajenación 
de bienes eclesiásticos... Podríamos destacar algunas de entre ellas como: Decretos de 1 de diciembre de 1810, 16 de abril de 1811, 22 de agosto de 1811 y órdenes de 17 de abril de 1811, 6 de mayo de 1811, 2 de diciembre de 1810 sobre prebendas eclesiásticas; Decretos de 28 de enero de 1811, 22 de agosto de 1811, 20 de abril de 1811 , orden de 4 de agosto de 1811 e instrucción de 20 de mayo de 1811 sobre fondos de obras pias aplicados a gastos del Estado; Decretode 20 de abril de 1811 sobre pensiones eclesiásticas que se aplican al Estado; y Decreto de 8 de mayo de 1811 sobre bienes de iglesia que tienen el mismo destino.

Se establece el secuestro en beneficio del Estado de todos los bienes pertenecientes a establecimientos públicos, cuerpos seculares eclesiásticos o religiosos de ambos sexos que hubieran sido disueltos, extinguidos o reformados por resultas de la invasión enemiga i de providencias del Gobiemo.

Podemos asegurar que la iglesia pagó más que ninguna otra organización el mantenimiento de la guerra de la Independencia y si se dieron oposiciones por parte de prelados fue fundamentalmente por considerar que la manera autoritaria con que eran exigidas las exacciones iba en contra de la inmunidad eclesiástica, o porque al prohibir la concesión de prebendas se privaba a los obispos de la libertad y el derecho que tenían a otorgarlas.

Siguiendo la misma línea, por decreto de 1812 quedó suprimida la carga conocida en varias provincias como "voto de Santiago" o contribución que era pagada por los campesinos de algunas regiones al cabildo compostelano.

Puede considerarse que con tales medidas quedaba bastante limitada la influencia y actuación de la iglesia.

Pero no fueron ellas solas las medidas y circunstancias que trajeron como consecuencia lógica la debilitación de la influencia de la Iglesia. A estas alturas de la reflexión que nos ocupa debemos citar tres aspectos que hemos dejado de lado hasta el momento, por considerarlos quizá los más fundamentales y explicativos de la cuestión religiosa que derivó de la Constitución de Cádiz. Y no son otros que: la libertad de imprenta, la abolición de la inquisición y la enseñanza.

MENENDEZ PELAYO (21) mantiene la tesis de que si bien en la confección del artículo 12 no se presentaron obstáculos fundamentales, sí surgieron estos y serias dificultades al plantearse y establecerse la libertad de imprenta y la supresión de la Inquisición. I se consiguió la omnímoda libertad de escribir y si bien los propios constituyentes no se atrevieron a sostener hasta sus últimas consecuencias legales la libertad religiosa, les pareció suficiente con echar por tierra la jurisdicción del Santo Oficio, único tribunal que podía hacer efectiva la responsabilidad de los delitos religiosos.

La libertad de imprenta quedó sancionada con referencia exclusivamente a la temática política, pero aún así fue aprovechada para dar cabida al ataque directo o velado contra la Iglesia y la religión, siendo de destacar el impacto que tales manifestaciones producirían en el pueblo.

Por lo que respecta a la abolición de la Inquisición (25), es obvio que lo que interesa no es tanto la Inquisición misma sino su significado. La Inquisición que 
había ya desaparecido con José Bonaparte, y hecho su reaparición bajo la fórmula de las Juntas de $\mathrm{Fe}$, vuelve a desaparecer de nuevo. Es tanto ahora como en épocas posteriores como el Guadiana de las instituciones eclesiásticas y su existencia o no vendrá de la mano de la alternancia en el poder de conservadores o liberales. La supresión del Santo Oficio privará a los integristas de su más poderoso instrumento y la caída del mismo se producirá fundamentalmente por las limitaciones que suponía para el ejercicio de la libertad de pensamiento y conciencia.

El hecho cierto fue que se le achacó públicamente la ignorancia de la religión, el atraso de las ciencias, la decadencia de las artes, del comercio y de la agricultura y la despoblación y pobreza de España.

El debate sobre la Inquisición fue representativo y característico de la diversidad de posturas encontradas que existían.

Ningún debate produjo tanto apasionamiento dentro y fuera de las Cortes como el que se ocupó de la Inquisición, pareciendo esto increíble si tenemos en cuenta la decadencia en que había caído el Santo Oficio; pero comprensible, si pensamos en lo que significaba la Inquisición, pues había quedado como un mito y símbolo de la concepción religiosa i tradicional de España. La defensa o el rechazo del Santo Oficio sirvió para deslindar campos políticos y fue uno de los elementos impulsores del dramático desgarramiento espiritual de la España contemporánea (26).

Nos queda por analizar, aunque sea someramente, un último punto: la enseñanza, que se va a ver influido e influirá en el tema central de la cuestión religiosa. En general los artículos de la Constitución en los que se regulaba revelaban un recelo hacia la Iglesia, esto produjo que quedara atribuido a las Cortes el establecimiento de planes y estatutos especiales que guardaran relación con la instrucción pública, y que se estipulase la uniformidad del plan general de enseñanza. Por otro lado, parece necesario destacar el hecho de que el Estado debía cuidar de que el niño se instruyera en el catecismo de la religión católica al mismo tiempo y del mismo modo que en sus obligaciones civiles.

Es por todo lo examinado, por lo que podemos concluir cerrando con ello el análisis de la Constitución y las Cortes de Cádiz, que en ella queda consagrada una manifestación expresa de confesionalidad, pero al mismo tiempo y tomando como punto de apoyo el precepto constitucional que obligaba al Estado a proteger la religión constitucionalizada en el mismo, las Cortes van a dictar multitud de medidas que implicaron fuertes cortapisas al desarrollo de la actividad e influencia de la Iglesia. De ahí que algunos autores hayan hablado del doble juego llevado a cabo por dichas Cortes (27).

Y como lo cierto es que, aunque las constituciones no tienen vigencia permanente, y a unos textos constitucionales siguen otros con menor o mayor rapidez como ha ocurrido en nuestra historia constitucional, estos textos constitucionales no nacen y mueren en sí mismos sino que las discusiones y debates que en ellos se encierran perviven en ocasiones más que los preceptos en los que quedaron dilucidadas y establecidas. Esto sin ir más lejos es lo que pasó con la cuestión religiosa que quedará como herencia en las discusiones políticas del siglo cuando de nuevo se 
aborden temas como la abolición del Santo Oficio, la libertad de pensamiento, la tolerancia religiosa, etc...

\section{NOTAS} 1981), 10.

(2) Vid. LAFUENTE, Historia Eclesiástica de España (Barcelona 1859), VIII, 464.

(3) Cfr. D. BASTERRA, El Derecho a la libertad religiosa y su tutela jurídica (Madrid 1989), 186.

(4) Vid. A. MOLINA, Derecho Canónico y Derecho Eclesiástico del Estado. EDICEP (Valencia 1983), 145.

(5) Cfr. P. A. PERLADO, La libertad religiosa en las Constituyentes del 69 (Pamplona 1970), 24.

(6) LAFUENTE, op. cit., 464.

(7) M. REVUELTA GONZÁLEZ, "La Iglesia española ante la crisis del antiguo régimen", (1803-33), Historia de la Iglesia en España, vol. V BAC (Madrid 1979), 28-26.

(8) Cf. M. REVUELTA GONZÁLEZ, Política religiosa de los liberales en el siglo XIX (Madrid 1973), 25.

(9) Cf. J. M. LABOA, op. cit. 13-14.

(10) Vid. M. REVUELTA, La Iglesia española, op. cit. 42.

(11) ARGÜELLES, Discurso Preliminar.

(12) Las cifras de sus componentes varían según los autores. Para SOLIS, historiador de Cádiz y sus Cortes, había 90 eclesiásticos, de ellos 21 canónigos, 6 obispos y 3 inquisidores; 56 juristas, de los que 22 eran fiscales; 30 militares, 9 marinos, 14 nobles, 15 catedráticos, 49 altos funcionarios, 8 comerciantes y 20 diputados sin profesión definida. Mientras que para FERNÁNDEZ ALMAGRO las cifras son de 97 clérigos, de ellos 3 obispos; 60 juristas, 55 burócratas, 37 militares, 16 catedráticos, 8 nobles y 35 más entre propietarios, comerciantes, escritores y médicos. Citados por D. BASTERRA, op. cit., 190, nota 23.

(13) Vid. M. REVUELTA GONZÁLEZ, op. cit., 36.

(14) Vid. A. MOLINA MELIÁ, op. cit., 148.

(15) Para el regalismo español pueden utilizarse los esquemas y la bibliografía expuestos en DE LA HERA, El Regalismo borbónico (Madrid 1963) y Notas para el estudio del regalismo español en el siglo XVIII, Atti del Convegno Internazionale di Studi Muratoriani, Módena 1972 (Firenze 1975).

(16) Baste citar a este respecto las fórmulas de juramento que quedan plasmadas en el texto gaditano. Así, y en cuanto a los diputados, el artículo 117 establecía: “¿Juráis defender y conservar la Religión Católica, apostólica, romana, sin admitir otra alguna en el Reino?", y terminaba diciendo: "Si así lo hiciereis, Dios os lo premie, y si no, os lo demande". En términos semejantes, el Rey debía jurar, defender y conservar la religión católica, sin permitir otra alguna en el Reino (artículo 173). 
(17) Vid. M. REVUELTA GONZÁLEZ, op. cit., 42.

(18) Vid. L. SÁNCHEZ AGESTA, Historia del Constitucionalismo español (Madrid 1978), 68.

(19) Diario de Sesiones, 25 de agosto de 1811. Merecen destacarse las intervenciones realizadas por los diputados SIMÓN LÓPEZ y RIESCO entre otros.

(20) Vid. L. SÁNCHEZ AGESTA, op. cit., 114.

(21) Cfr. F. FERNÁNDEZ SEGADO, Las Constituciones históricas españolas (Madrid 1986), 94.

(22) Vid. A. ARGÜELLES, La reforma constitucional de Cádiz, estudio y notas por J. CONGARAS (Madrid 1970).

(23) En cuanto a la actividad legislativa de las Cortes de Cádiz, pueden consultarse además de las obras ya citadas de F. FERNÁNDEZ SEGADO y P. A. PERLADO, a M. REVUELTA, "La Iglesia española ante la crisis del Antiguo Régimen (1803-1833)", Historia de la Iglesia en España (Madrid 1979), vol. V, 3-313. Así mismo resulta interesante la clasificación por materias y tipos de normas que se contiene en la obra de J. CHOPRE SIRVENT, Codificación de las normas aprobadas por las cortes (1810 - 1837), Instituto de Cultura Juan Gil-Albert, Alicante, 1992.

(24) Cfr. M. MENÉNDEZ PELAYO, Historia de los heterodoxos españoles (Madrid 1978), BAC, vol. II, 698-710.

(25) F. MARTI GILABERT, La abolición de la Inquisición en España (Pamplona 1975).

(26) Cfr. M. REVUELTA GONZÁLEZ, op. cit., 46-52.

(27) Entre ellos P. A. PERLADO, op. cit., 25, y D. BASTERRA, op. cit., 196. 


\title{
¿ES POSIBLE AGILIZAR LA VIA DE APREMIO?
}

\author{
ANTONIO NAVAS SEGURA
}

Prof. Asociado Derecho Civil

\section{SUMARIO:}

I.- JUSTIFICACION.

II.- TRAMITES DE EJECUCION DE SENTENCIA, ACTUALMENTE.

1.- En cuanto al avalúo y cargas.

2.- Comentario.

III.- REFORMA QUE SE PROPONE.

IV.- GARANTIAS.

1.- En cuanto al deudor.

2.- En cuanto a la publicidad respecto a los acreedores.

V.- CONCLUSIONES.

\section{I.- JUSTIFICACION.}

Las presentes notas no pretenden ser un estudio sobre la ejecución de sentencia, sino una aportación, aunque sea rudimentaria, vista por un abogado que día a día tiene que enfrentarse a los múltiples trámites que aquella lleva consigo y que podrían ser simplificables.

En una posible reforma de la Ley de Enjuciamiento Civil podría permitirse una mayor participación a la actividad de las partes, realizando estas algunas actuaciones que hoy se efectúan a través de peticiones al Juzgado, y que acelerarían los procedimientos.

Esas notas queremos centrarlas en aquellas ejecuciones en que los bienes trabados pertenecen, como dice la Ley de Ritos, a la clase de los inmuebles.

Lógicamente los redactores de la Ley adjetiva tenían como misión fundamental que en una ejecución de sentencia, además de garantizar el cobro de su crédito por los acreedores, quedarán salvaguardados los intereses de los deudores, pero la cantidad de procedimientos que se turnan diariamente en los Juzgados, el trabajo que pesa sobre la oficina judicial, y en general, por la causa que sea, pues tampoco vamos ahora a analizarla, cuando se entra en la ejecución empieza lo que podemos denominar un verdadero viacrucis, hasta el cobro total, si se llega a ello, de las cantidades adeudadas. 
Esta larguísima tramitación en verdad no beneficia a nadie, ni al acreedor porque cuando pecibe el importe de su crédito, con la lógica devaluación progresiva de la moneda, ha perdido poder adquisitivo, ni al deudor porque la acumulación de intereses hacen que la deuda inicial se duplique o triplique, o en algunos casos sea mayor aún la proporción, pensemos en procedimientos de entidades de crédito, actualmente la mayoría, en que los intereses de demora están pactados, y casi siempre ronda el $20 \%$.

La lentitud en una ejecución, repetimos, no beneficia a nadie, pero además tenemos, y esto a mi juicio es lo más importante, la paulatina pérdida de confianza en las reclamaciones judiciales, y la administración de justicia es la base en todo estado de derecho.

\section{II.- TRAMITES DE EJECUCION DE SENTENCIA, ACTUALMENTE.}

Vamos a entrar ya en lo que es la ejecución de la sentencia, para a continuación exponer lo que podría ser en un futuro, si estas notas sirven para una reflexión.

1.- En cuanto al avalúo y cargas.

Actualmente, si los bienes pertenecen a la clase de los inmuebles, por utilizar la expresión del art. 1.489, encontramos la siguiente tramitación:

A) El ejecutante interesa al Juzgado, que lo expide, mandamiento dirigido al Registro de la Propiedad donde estén inscritas las fincas embargadas para que libre certificación en la que se hará constar las hipotecas, censos y gravémenes a que están afectados los bienes, o se certifique la libertad de ellos.

Al mismo tiempo, se requerirá al deudor para que en el plazo de seis días presente en la Escribanía los títulos de propiedad de las fincas (art. 1.489).

B) Una vez certificadas cargas, si los inmuebles estuviesen gravados con segundas o posteriores hipotecas, no canceladas, se hará saber a los acreedores hipotecarios para que puedan participar en el avalúo y subasta (art. 1.490).

C) Para el avalúo de los bienes se designa un perito por el ejecutante y se da conocimiento al deudor para que, si le interesa, nombre otro en el plazo de dos días bajo apercibimiento de tenerle por conforme con el designado.

Puede que al recibir esta notificación el ejecutado se persone en autos y designe otro, mándandose entonces que acepte el cargo, y si no lo acepta se requerirá al demandado para que nombre un segundo, y si tampoco aceptase se hará la valoración por el nombrado por el ejecutante, pudiendo el juez nombrar otro.

Hecha la valoración se solicitará la subasta.

\section{2.- Comentario.}

Lo expuesto nos lleva a que una ejecución se prolongue más de un año, con el consiguiente aumento de la deuda, para el ejecutado, por los intereses y la pérdida del poder adquisitivo para el acreedor por la depreciación lógica de la moneda, es decir, a nadie interesa que una ejecución se prolongue tanto tiempo.

Como decíamos al principio, todos esos trámites previstos en la Ley de 
Enjuiciamiento Civil están ordenados a que exista una garantía para el ejecutado (posibilidad de intervenir en el avalúo) y para los titulares de derechos reales de garantía sobre los inmuebles que se ejecutan, (la notificación a acreedores con segundas o posteriores hipotecas) para que puedan subrogarse en el crédito del actor, previo su pago y también participar en el avalúo de los bienes.

Pero lo que también es cierto es que en la época en que se promulgó la L.E.C., no había tanta litigiosidad, y las ejecuciones de las sentencias eran contadas; es más, tampoco hay que remontarse a finales del siglo pasado, hace 15 ó 20 años eran escasos los procedimientos tanto declarativos como ejecutivos que se solucionaban con la subasta de los bienes, sin embargo hoy es más fácil que se acabe un procedimieto con la subasta a que se solucione al dictarse sentencia o inmediatamente después de solicitarse la ejecución.

Ello hace que se imponga una reforma en los trámites que aseguren una más eficaz tramitación, sin que exista incompatibilidad entre la rapidez y las garantías antes aludidas, para el ejecutado y terceros.

\section{III.- REFORMA QUE SE PROPONE}

El decir que la Ley debe salvaguardar las garantías de los ejecutados, y dar más cabida a la actividad de las partes no significa un contrasentido, ya que ambas cosas son totalmente compatibles, y en ello se fundamenta este trabajo.

No voy a efectuar una redacción de lo que podrían ser los preceptos de la Ley de Enjuiciamiento Civil, sino aportar unas ideas para que de ser acogidas, al menos en parte, sean una ayuda al redactar los preceptos adjetivos.

Una vez dictada la sentencia, el actor podría presentar escrito al Juzgado al que acompañará certificación expedida por el Registro de la Propiedad, solicitada (por el acreedor sin intervención judicial) con fecha posterior a la firmeza de la resolución judicial, en la que se haga constar las cargas que pesan sobre el inmueble sobre el que se ha practicado el embargo y la naturaleza de estas.

Si de dicha certificación aparecieren los bienes gravados con segundas o posteriores hipotecas se acompañará copia de Acta notarial en la que se haga constar haber notificado a los acreedores inscritos con dichas hipotecas la existencia del procedimiento y si quieren hacer efectiva la deuda con subrogación en el crédito del actor o participar en el avalúo, siendo estos requerimientos de fecha posterior a la certificación expedida por el Sr. Registrador de la Propiedad.

Al mismo tiempo, y también de fecha posterior se presentará valoración efectuada por perito, de los bienes embargados y Acta notarial notificando al deudor el perito designado y la valoración efectuada, para que en el plazo de cinco días pueda presentar otra valoración realizada por otro perito elegido por él. Si ambas valoraciones no excediesen de un $10 \%$ se fijará como precio de subasta el mayor, y si excediese de ese porcentaje el Juzgado designará un tercero cuya valoración será el tipo de subasta.

Transcurrido el pazo que se conceda en el Acta de notificación al deudor, el acreedor podrá solicitar la subasta de los bienes. 
Conscientes de que este sistema en algunos casos puede plantear alguna dificultad sobre notificaciones, nada impide que puedan subsistir ambos sistemas, el actual y el que se propone, a elección del actor, como actualmente se da en el procedimento especial sumario del art. 131 de la Ley Hipotecaria, en el que el acreedor puede realizar el requerimiento de pago, bien notarialmente o bien dentro del mismo procedimiento.

\section{IV.- GARANTIAS}

\section{1.- En cuanto al deudor.}

Ya hemos dicho anteriormente, que el trámite de ejecución de sentencia tiene que velar por las garantías de los deudores, para lo que existe la fe pública judicial en todas las actuaciones, -intervención del secretario-; lo que se propone es que se dé la misma fé pública, sustituyendo al Secretario Judicial por un Notario, con lo que las garantías tanto frente al deudor como ante terceros acreedores no se ven lesionadas en ningún momento, incluso podría extenderse la notificación a aquellos acreedores posteriores que no lo fueran por hipotecas, sino por embargos como ocurre en el procedimiento especial sumario del art. 131 de la Ley Hipotecaria.

La intervención del Notario es suficiente garantía, aumentándose aún bajo la supervisión judicial del cumplimiento de los requisitos previstos en la Ley.

Esta actuación notarial y validez de las notificaciones existe ya en el procedimiento ejecutivo extrajudicial previsto en la Ley Hipotecaria, en el que a los acreedores posteriores se les efectúa las notificaciones a través del Notario, al igual que, como hemos dicho, en el procedimiento especial sumario previsto en el artículo 131 de la Ley Hipotecaria, el requerimiento de pago al deudor puede hacerse en el mismo procedimiento o acreditar haberlo hecho realizado con anterioridad de forma notarial.

Ahora bien, donde más garantía ofrece, a nuestro juicio, este sistema es en lo concerniente a la valoración de los bienes, porque en realidad a un deudor le tiene sin cuidado quién va a ser el perito que valore sus bienes, salvo que hubiese una enemistad personal entre ambos, cosa casi improbable. Lo que realmente le interesa es el valor que se va a dar a esos bienes, y tal como está redactada hoy día la Ley de Enjuiciamiento Civil lo único que se notifica es quién es el perito designado por si el deudor quiere nombrar otro por su parte, y si no lo hace confiando en que se dará una valoración acorde con la que él considera su valor, puede éste perito nombrado por el acreedor hacer la valoración que estime conveniente sin posibilidad del ejecutado de presentar otra, tal vez más cerca de la realidad.

Al mismo tiempo se evitan las picarescas de algunos ejecutados que cuando se les notifica el nombramiento de perito, hacen la designación de otro que no acepte para que se le requiera de nombramiento de un segundo que tampoco acepta, alargando así un procedimiento, ya de por sí largo, siempre en perjuicio del acreedor.

Por otro lado, el principal interesado en que el procediminento se solucione rápidamente será el propio acreedor, por lo que pondrá la máxima diligencia en cumplimentar los trámites que se han apuntado. 
Y por último, en cuanto a beneficiados, nos encontramos con el propio deudor que tiene conocimiento puntual y exacto del valor del inmueble antes de que sea solicitada la subasta con lo que podrá poner los medios necesarios para su verdadera valoración, y no como ocurre ahora, que si no nombra perito cuando se le notifica el designado por el acreedor, por estimar que la valoración va a ser la correcta, sólo tiene conocimiento del valor cuando se le notifica la fecha de la subasta y si tiene la precaución de examinar los autos; y la superbeneficiada es precisamente la administración de justicia, que sería mucho más ágil sin dejar de garantizar los intereses de los intervinientes en un procedimiento.

2.- En cuanto a la publicidad respecto a los acreedores.

La notificación se hacía personalmente o a través del procedimiento seguido a instancia del acreedor posterior en la persona del procurador de los tribunales que ostenta su representación, y, actualmente se efectúa también por carta certificada con acuse de recibo, que si bien no vamos a cuestionar la legalidad de este sistema, sí podemos afirmar que no es el más idoneo y produce grandes retrasos porque se puede dar, y de hecho se dá, extravíos en los acuses de recibo, con lo que si no consta en autos tiene que volver a realizarse.

También nos encontramos con que el destinatario puede estar ausente de su domicilio en horas de reparto, cosa bastante habitual, salvo que se trate de empresas, al coincidir el horario de reparto del servicio de correos con las jornadas laborales -es cada vez más frecuente que ambos cónyuges tengan una actividad laboral fuera del domicilio- con lo que al estar ausentes se deja nota para que el destinatario se persone en las oficinas de correos a retirar el certificado que si no se realiza en el plazo de 30 días es devuelto caducado, por lo que al no haberse efectuado la notificación debe realizarse de nuevo. Ello supone verdaderos retrasos en cumplimentar los trámites procesales $\mathrm{y}$, en consecuencia, del procedimiento.

Siendo el notario quien comparece y da fe de su entrega no existe extravío y si no se encuentra el destinatario en ese momento, realizará un segundo o un tercer intento en distintas horas hasta su notificación, ello en breves días con lo que se da una economía de tiempo.

\section{- CONCLUSIONES -}

PRIMERA.- La actividad de los interesados en la realización de actos conducentes a la aceleración de los procedimientos no es una novedad en nuestra legislación (art. 131 L.H.), lo que se propone es que se le de carta de naturaleza en la fase de ejecución de sentencia.

SEGUNDA.- El suplir esta actividad hoy reservada a la oficina judicial, a petición de parte, por la del propio interesado con unificación de trámites y conservándo las garantías de terceros y del propio ejecutado -intervención de notario-, haría más rápida y eficaz la ejecución de las sentencias, trámite donde hoy se producen los auténticos atrasos en los procedimientos. 
ADDENDA.- Ya en prensa este trabajo, por Ley 10/1992, de 30 de abril, de Medidas Urgentes de Reforma Procesal, se ha reformado, entre otros, el art. 1490 de la Ley de Enjuiciamiento Civil, quedando redactado como sigue:

"El Registrador de la Propiedad comunicará a los titulares de derechos que figuren en la certificación de cargas y que consten en asientos posteriores al del gravamen que se ejecuta, el estado de la ejecución para que puedan intervenir en el avalúo y subasta de los bienes, si les conveniere.

La comunicación se practicará en el domicilio que conste en el Registro por correo o telégrafo. En la certificación a que se refiere el artículo anterior se expresará al haberse practicado esta comunicación".

Se inicia un intento, aunque tímido, de desjudicializar algún trámite en la ejecución, como se propone en este trabajo. 


\title{
NOTAS HISTÓRICAS SOBRE LA JUSTICIA GRATUITA EN ESPAÑA
}

\author{
INÉS PEDRAZ PENALVA
}

Profesora Agregada de Geografía e Historia I.B.

\section{SUMARIO.}

I 1 Introducción.

II 2. Delimitación del estudio.

3. Sobre la Justicia gratuita en los Ordenamientos históricos italiano y francés.

III 4. Configuración histórico-normativa de la Justicia gratuita en España.

5. Requisitos exigibles a las personas físicas para gozar del beneficio de pobreza.

6. Beneficios y limitaciones que implica el reconocimiento de la pobreza.

7. La pobreza de las personas jurídicas.

IV 8. A modo de colofón.

I.-1. Antes de entrar en lo que constituye el punto central de estas breves reflexiones históricas sobre el derecho a la Justicia gratuita, acaso conviniera esbozar, a muy grandes rasgos, la actual situación de este derecho de categoría constitucional.

La primera posición que ocupa en nuestro Ordenamiento Jurídico la Ley Fundamental es determinante a efectos del derecho básico de toda persona a la obtención de la tutela judicial efectiva, en defensa de sus derechos e intereses legítimos, sin que pueda sufrir indefensión (1). Pero tal Derecho Fundamental del art. 24,1 de la Constitución española, en su desarrollo por nuestro Tribunal Constitucional, comporta, singularmente, la exigencia de que se supriman cualesquiera obstáculos susceptibles de impedir la plena vigencia del citado Derecho del Art. $24 \mathrm{CE}$. Precisamente, el elevado coste de la Justicia es uno de los óbices capaces de convertir en ilusorio tal derecho de acceso a la Jurisdicción, motivo por el que el legislador constituyente proclamó,en el art. $119 \mathrm{CE}$, de manera especifica, que "La Justicia será gratuita cuando así lo disponga la Ley y, en todo caso, respecto de quienes acrediten insuficiendia de recursos para litigar".

Cabe citar a este respecto la actual plasmación del Derecho a la justicia gratuita en diversos Convenios internacionales, tales como el Pacto Internacional de Derechos Civiles y Políticos de New York, de 19 de Diciembre de 1966 (ratificado por España en 27 de Abril de 1977), en su artículo 14.3.d, el Convenio Europeo para la protección de los Derechos Humanos y de las Libertades Fundamentales, aprobado en Roma en 4 de Noviembre de 1950 (ratificado por España en 26 de septiembre de 1979), en su artículo 6.3.c, etc. 
Destacaré pues la regulación constitucional del derecho de acceso a la Justicia de todas las personas, sin que puedan sufrir discriminación por razón de insuficiencia de medios económicos, lo que, además, vulneraría el principio de igualdad del artículo $14 \mathrm{CE}$ (2).

II.-2. Al hablar de la configuración histórica del derecho a la Justicia gratuita se pretende solamente ubicar el tema, sin ir más allá de lo dicho en el apartado anterior ni aludir a la regulación normativa vigente, lo que excedería tanto del objetivo propuesto como de la metodología y aparato conceptual precisos para ello. Esto, no osbatante, y según podrá comprobarse, he tenido que acudir por la propia entidad temática, a examinar de manera especial textos jurídicos, que son los que, lógicamente, acomenten la reglamentación del derecho a la justicia gratuita.

II.-3. La solución históricamente más radical -con una cierta pero esporádica continuidad- sobre la Justicia gratuita, se encuentra en la institución "iuscanonista" del "adbocatus pauperum deputatus et stipendiatus" (3). Este "advocatus pauperum..." constituía un oficio permanente, con deteminadas funciones y privilegios, susceptible de ser considerado en cierta medida, desde perspectivas actuales, como un "servicio público tendente a ejercer el patrocinio gratuito de los pobres" (4).

Distinto de tal instituto del Derecho canónico era la "abogacía de pobres", diferenciándose por FERRARIS (5) en cuanto que "est hoc expresse praeceptum a Paulo V... et hoc intellige ubi non repetitur deputatus et stipendiatus propios advocatus pauperum, quia, ubi adest ille... adest ille, non tenentur allii, cum ipse teneatur ex iustitia et officio, ratione stipendii et privilegiorum, et maxime privilegii fori, quo gaudet etiamsi sit laicus, ut declaravit sana congragatio inmunitatis in Beneventan a 20 Julii 1655". Por autores como CAPPELLETTI se ha llegado a decir que la realización de esta avanzada idea quedó en las buenas intenciones, lógicamente en cuanto se trataba de una tentativa ideológicamente prematura en una época feudal dotada de una organización político-social jerárquicamente desigual. (6).

La "Abogacía de pobres" aparece en Italia hacia fines del S. XIV en los Estados saboyanos e incluso en el XIII, en Parma (7). En Italia subsistió en el reino del Piamonte "una avvocatura dei poveri', con un ámbito de actuación verdaderamente muy limitado (8), extendida a todo el reino de Italia en un primer momento (Ley Ratazzi, de 13 de Noviembre de 1859) y casi inmediatamente suprimida (Ley Cortese de 6 de Diciembre de 1865) por razones económicas presupuestarias.

En Francia, fue durane el reinado de Enrique IV cuando se instauró la "abogacía de pobres" -mediante un decreto de 6 de Marzo de 1610-, norma en la que se ordenaba que en todos los Tribunales hubiera abogados para pobres, los cuales tendrían el deber de defender y patrocinar gratuitamente a todos los que cumplieran determinados requisitos, con una prohibición formal de recibir en cualquier forma compensación alguna, y con la única retribución que el soberano hubiese estimado conceder.

No es por tanto, tal "abogacía de pobres" el instituto del "advocatus deputatus et stipendiatus" del Derecho canónico, sino un encargo especial para la defensa de los pobres.

La "abogacía de pobres" pasó por diversas vicisitudes en Italia, llegando a ser 
asumida por los propios "Colegios de Abogados" que incluso, en algunas regiones, llegaron a establecer un día semanal de consultas gratuitas para los pobres que se presentaran (9).

En Francia, tras el reinado de Enrique IV llegó prácticamente a desaparecer la abogacía de pobres.

III.-4. También en España aparecen diversos intentos para institucionalizar una "abogacía de pobres" remunerada con fondos públicos, con un marcado carácter intervencionista del monarca y de control -lo que claramente se evidencia, como veremos después, por estimar "casos de corte" a quellos en los que estuvieran interesados pobres, huérfanos, etc.- coexistiendo en gran medida con el sistema que va a terminar también por predominar en España: atribución y correspondiente asunción de tal tarea por Letrados y Voceros que, designados de oficio, se ven obligados a hacerse cargo de ella.

Entre los datos histórico-normativos con los que contamos para hablar de una institucionalización de la defensa de los pobres, tenemos los pobres, tenemos los siguientes:

a) Ley de Adelantados mayores, en cuya L II se dice: "...et si por aventura duenna biuda, o huerfanos, o ome de orden, o cavallero que non aya sennor, e otro que sea reptado oviera pleyto fuer tan poderoso por que el adelantrado nol pueda dar otro tan poderoso por bocero, en adelantrado lo pueda ser por mandato del Rey" (10). Se encomienda a los Adelantados, entre otras, la defensa de viudas, huérfanos y "muy cuitados", debiéndose asimismo destacar que le competía, en general, la protección de los desvalidos, no solo económica sino socialmente.

b) Más tarde aparece la figura del Procurador-Fiscal, como oficial regio encargado de la defensa de los pobres. En la Ley de Estilo Li puede encontrarse un dato importante respecto al oficio de Promotor o Procurador-Fiscal, permitiendo afirmar la doble función que va a tener: Abogado de Rey en lo civil (en lo penal, el manarca no podía ser enjuiciado) y acusador público en lo penal.

La institucionalización de esta figura no se produce hasta las Cortes de Valladolid de 1312 y Ordenanzas Reales en que se fundaron las disposiciones de dicha reunión. Así se determinó: "Otrosi tengo por bien de haber un procurador que demande, razone é defienda por mio los mios pleytos, é los de las viudas pobres, é de los huerfanos pobres, é comunalmente de todos los huerfanos, que ovieren pleyto en la mi corte" (11).

A partir de este momento puede afirmarse la creación de tal oficio con carácter profesional y permanente, sin perjuicio del ejercicio eventual, total o parcial, de las mismas funciones por parte de individuos designados por el Rey para cada caso concreto y con seguridad entre dos Letrados de la Corte. Destaquemos también que tal oficio se actuará solamente ante los Tribunales de la Corte, es decir, en la cima de la jerarquía judicial, por tratarse de un ógano de la Administración central.

Prescindiendo ahora de que el Promotor fiscal se presenta como procurador de los pleitos del Rey, incluyendo aquellos casos de corte de caráter penal que, por una u otra razón, no sean perseguidos a instancia de parte (según se deduce de una generalización lícita de lo expuesto en la mencionada Ley II de las de Estilo), maticemos 
que aparece -al igual que sucedía con los Adelantados Mayores- como Abogado de los desvalidos social y económicamente, lo que en realidad es un "caso de corte" más (12).

Precisamente, como destacamos más arriba, la atribución de esta tarea (Abogado de los pobres) es uno de los datos que permite su conexión difusa con el Adelantado Mayor de la Corte y más claramente, con los Abogados de pobres, cargo este último creado quizás como alternativa parcial por Alfonso X en 1274. Así, en las Cortes de Zamora de 1274 se dice que: "en ninguno pleito pequenno, quello non razonen ellos, sinon si lo razonaren ayudando a los mesquinos pobres porque sean mas ayna librados. E por esto delos pobres, que tome el Rey dos Abogados sennalados, que sean omes buenos e que teman a Dios e sus almas, e que otro pleito ninguno non tengan sinon de los pobres, que les faga el Rey por quelo puedan facer. E esto se entiende delos mas pobres que a la corte vinieren, tales que no ayan que dar a los avogados" (13).

Con anterioridad, según nos dicen las Leyes de Estilo, cualquier Abogado tenía la obligación de actuar de oficio en caso de ser pobre el litigante. Así, en la L.XX: "El Abogado por su salario si aquel ha de dar salario no ha bienes de que lo pague, no gelo dara presso: vaya el ayuda que le fizo por el amor de Dios".

En principio quizás fuera factible presumir que ese oficio de "Abogado de pobres" que resucitará durante el siglo $\mathrm{XV}$, quedó sumido en el oficio de Procurador-Fiscal.

En la evolución posterior del Promotor (o Procurador) Fiscal, es destacable su duplicación (14) creándose dos procuradurías que respectivamente actuarian ante las dos instancias judiciales máximas: Audiencia y Consejo, adquiriendo una progresiva y cualitativa inportancia, dadas las atribuciones penales que se les reconoce (correlativas al desarrollo e implantación del sistema inquisitivo o de oficio propio de unas estructuras políticas más evolucionadas).

La importante reorganización de la Chancilleria llevada a cabo por Juan II en 1438, también afectó a la Procuraduría Real que actuaba ante dicho Tribunal (15), disponiéndose que en lo sucesivo quedara servida por dos personas que probablemente actuarían de forma alternativa o bien que especializarían seguramente sus funciones, uno en lo civil ante los Oidores y otro en lo penal ante los Alcaldes del Crimen, distribución que entendemos meramente funcional. Es más, y esto es lo importante para nosotros: se estableció la existencia de dos Abogados de pobres que, cnlazando con aquellos otros creados por Alfonso $\mathrm{X}$, tendrían a su cargo precisamente una de las misiones que desde su institucionalización se encomendó al Promotor-Fiscal; aunque carecemos de noticias en que apoyarnos, es de suponer que tales letrados debieron ser oficiales judiciales de la Administración castellana a nivel central desde muchos años antes, probablemente desde poco después de instituir la Audiencia.

Así, en las Ordenanzas Reales de Castilla, Lib. II, Tit. IV, Ley 1 se dice: "...Porende ordenamos y mandamos que en la nuestra Corte y Chancillería residan continuamente un Prelado, Presidente y quatro Oidores, y tres Alcaldes de la Carcel, y dos Procuradores Fiscales, y dos Abogados de los pobres...". 
c) Como ya se señaló más arriba, la defensa de pobres asumida por oficiales de la Administración central, mediante los Adelantados mayores en un primer momento y con posterioridad, por los Promotores-Fiscales, sin olvidar a los Abogados de pobres instaurados por Alfonso X y que vuelven a aparecer con Juan II en 1493, se simultaneó en gran medida con la designación de oficio por el Juez de Abogado y Vocero sque han de encargarse de la misma.

Destaquemos que la obligación de asumir tal mandato judicial se mantiene, pese a la consideración de que los pleitos de viudas, huérfanos y pobres constituyen "casos de corte"; así, en el Espéculo, I. 13, tit. 2, lib. IV, en la Ley de Estilo 91 ("...Estas son las cosas que fueron siempre usadas de librarse por la Corte del Rey: muerte segura, é muger forçada, é tregua quebrantada, salvo quebrantado, casa quemada... Y eso mismo los pleytos de viudad, é de huerfanos, é de cuytadas personas"). En I. 15, tit. 3, 3 Partida ("Contiendas e Pleytos y ha, sin aquellos que auemos dicho en la Ley ante desta, que son de tal natura, que segun Fuero de España, por razon dellos son tenudos los demandados de responder antel Rey, maguer non les demandassen primeramente por su fuero. E son estos: quebrantamiento de camino, o de tregua, riepto de muerte segura, muger forçada, ladron conoscido... o por razón de otro grand yerro de trayción, que quisiessen facer al Rey, o al Reyno; o por pleyto que demandasse huerfano, o ome pobre, o muy cuytado, contra algund poderoso, de que non podiesse tambien alcançar derecho por el fuero de la tierra. Ca sobre qualquier de estas razones, tenudo es el demandado de responder ante el Rey, do quier que lo emplazassen...".

En este sentido, HEVIA VOLAÑO nos dice que: Tiene también caso de corte el menor de veinte y cinco años huerfano de padre, y no basta ser lo uno sin lo otro... Tiene tambien caso de corte la viuda que viue honesta y recogidamente. Y lo mismo la muger que lo viuiere, aunque no se aya casado, no teniendo marido... Y tambien la muger casada que tiene el marido inutil, preso o desterrado, o de galeras, o en captiuerio, se tiene por viuda, para gozar (como goza) de priuilegio de caso de Corte, la viuda, menores, herfanos, pobres y personas miserables que tienen priuilegio de caso de Corte, le tienen como actores y reos, assi en demandando, como en defendiendo... Estas personas que tienen priuilegio de caso de Corte, nolo tien en ni gozan del en causas que sean de diez mil marauedies y de ay abaxo, sino dellos arriba... Ni tampoco gozan del dicho priuilegio en las causas sobre el aurer del Rey, o executiuas o criminales, o si se contesta la demanda ante el juez inferior sin declinar jurisdiction... (16).

En el mismo tenor, Alonso de VILLADIEGO, quien asimismo distingue entre "Casos de Corte" notorios o no. Los notorios son los de "...un Concejo contra otro; y los de Cabildos, y Monasterios, Hospitales... y contra los Grandes, y Señores de título, y contra los Oficiales y criados del Rey, puestos en oficio, y Dignidades supremas; qualquiera de estos casos se dice notorio, por ser cosa notoria, y basta alegarlos, sino que es necesario dar información sobre la calidad de ellos; como son el peyto del menor de veinte y cinco años y el de la muger viuda que viue honestamente...y lo mismo tiene Caso de Corte el pobre, y necesitado..." (17).

Con independencia del encargo real, la legislación histórica recoge con carácter 
general la necesidad de defensa gratuita del pobre, justificando la asunción de tal deber en el "amor de Dios", (Ley XX de la de Estilo).

Otro testimonio, si cabe aún más claro, se recoge en la $I, 6$, tít. 6 , de la $3^{\mathrm{a}}$ Partida, donde no sería aventurado hablar de "Abogado de Oficio"; en este caso, serán los "Juzgadores" quienes deban dar Abogado a las personas que lo soliciten ("Biuda, é huerfano, é otras personas cuytadas, han de seguir a las veces en juyzio sus pleitos. E porque aquellos con quien han de contender son poderosos, acaesce que non puedan fallar Abogado, que se atreua a razonar por ellos. Onde dezimos, que los Judgadores deuen dar Abogado, a cualquier de las personas sobredichas que gelo pidiere. E el Abogado, a quien el Juez lo mandare, deue razonar por ella por mesurado salario. E si por auentura fuesse tan cuytada persona, que non ouiesse de que lo pagar, deuele mandar el Juez que lo faga por amor de Dios, el Abogado es tenudo de lo facer..." (18).

d) Durante los siglos XIX y actual, por tanto desde la codificación precesal, la situación adquiere connotaciones específicas que no serán objeto de estudio.

El cumplimiento del encargo real de asumir la protección y defensa de los desvalidos o del mandato judicial de encargarse, de oficio y "por amor de Dios" de ella, viene asegurado por una Legislación que regula el veneficio de pobreza:

- En la Ley IV de las de los Adelantados Mayores ("...é que non tome nada de los pobres por quien razonarse, nin sea contra ellos, é si yo fallar que lo asi non guarda, haya sobre si las penas de los alcaldes...").

- En la Ley XIII del Espéculo ("... E si el alcalle mandare a alguno de los voceros que suelen tener cutianamente en la Corte, que tenga la voz de alguno, e non lo quisiere facer, devel alcalle defender por pena que no tena voz fasta un año en ningun pleyto, sino en aquellos que los pueda facer por derecho, segunt dice en el titulo que fabla de los voceros... E esto mismo dezimos que deven facer los adelantados de las merindades, e los alcalles, e los juezes de las villas, cada uno en aquellos logares en que an de judgar...").

- En las Cortes de Valladolid de 1312, 23 ("...e que non tome nada de los poures por quien rrazonares ninsea contra ellos. Et si yo fallar quelo assi non guarda, que aya sobre si la pena que es puesta sobre los dichos alcalles...").

En la Nueva Recop,. 1.28 tit.5, lib. 2 ("...Mandamos a los dichos nuestro Presidente, y Oidores, que se informen de los que litigan por pobres si los letrados siguen bien, y con diligencias sus causas, y los escriuanos, y si los otros oficiales de la nuestra Audiencia les lleua derechos; y los que halaren que tienen en ello culpa, los castigaren conforme a la justicia, y a los que de aqui delante excedieren en ello: y que prouean, como por culpa de los Letrados y procuradores de pobres, y otros Oficiales de la dicha nuestra Audiencia no se dilaten sus causas").

- También en la Nov. Recop. en el parágr. 83, de la 1,11, tit. 24, lib. 10 ("...que aque deba entenderse pobre de solemnidad, que se excusa de pagar derechos de Escribano, Abogado, Procurador, Solicitador, y Juez... y si se probare que algunos los hubiere llevado, pague cualquiera que lo hubiere hecho los derechos que tocan a los dichos sellos conel doblo; bastando para esta multa la deposición de un testigo, y la dé parte"). 
La legislación en la que ordena que no se dilaten las causas de los pobres está recogida:

- En la citada Ley 28, tit.5, lib.2 de la Nueva Recopilación.

- En la Ley 17, tit.2, lib.3 de la Nova Recopilación ("Mandamos, que en ver los pleitos conclusos guarden la orden y las leyes que se guarda en nuestras Audiencias; y que los sabados se vean pleitos de pobres y libertades, y Hospitales y Monasterios, e Iglesias, prefiriendo a los que mas razon huuiere...").

III.- 5. En cuanto a los requisitos para gozar de la defensa por encargo real o por decisión judicial:

1) Que se trate de viudas, huérfanos o pobres.

2) Respecto a los pobres, en la 1.20 , tit.23 de la $3^{\mathrm{a}}$ Partida, se equiparan a viudas, huérfanos, etc. y personas desamparadas los pobres que "non han valia de veinte marauedies".

3) Que se trate de personas socialmente desvalidas, y no únicamente desde el punto de vista económico. De este modo se encomienda su defensa a los Adelantados (L.II. cit.); El Juez designa Abogado cuando por ser el pleito con poderosos, no pueden encontrar a alguno que "se atreua a razonar por ellos" (Ley 6, tit. 6, Partida $3^{\circ}$ ).

4) Tratándose de pobres que lo acrediten:

- a). "Jurando serlo". Así, en L20, tit.XII, lib.1² (Nueva Recop., habien acordada en 1519): "Mandamos que las personas pobres, que agora, y de aqui en adelante estuvieren presos en las carceles, siendo despachados, y mandados librar en sus causas, jurando que son pobres y que no tienen de que pagar...".

- b). Y como se previene en la 1.25, tit.12, lib. $1^{9}$ de la Nueva Recop. -disposición que es la primera en la que hemos encontrado requisitos concretos para gozar del beneficio de pobreza, estando bajo la rúbrica "Con que información el pobre se ha de tener por pobre en las Audiencias para gozar de no pagar derechos": "...Mandamos, que quando alguno se dize pobre, para se escusar de pagar derechos á los oficiales de la Audiencias, que baste la información que de su pobreza truxere de fuera parte, dando un testigo en la Audiendia, que concluya: con tanto, que le tome el escriuano de la causa". Aunque recogida en este texto de 1567, en realidad proviene de una cédula dada por Carlos I en Monzón, en 1542. Esta Ley pasará posteriomente a la 1.7 , tit. 19, lib. $5^{\circ}$ de la Novísima Recopilación.

- c). En la Novísima Recopilación de 1805, aparte de las leyes señaladas al hablar de la Nueva Recop. y que pasan íntegramente, se puede apreciar el diferente tratamiento en la averiguación de la pobreza.

Los parágrafos 82,83 , y 84 de la 1.11 , tit.24, lib. 19 se refieren a los pobres. De todos ellos, el que más nos interesa en este momento es el 83, en el que se determina que "Para que no pueda hacer fraude en la averiguación y probanza de la pobreza, se declara, que aquel deba entenderse pobre solemnidad, que se excusa de pagar derechos de Escribano, Abogado, Procurador, Solicitador y Juez: bastando para este efecto la misma información que se hace, con arreglo á lo dispuesto por otras leyes, 
para probar la calidad de pobreza, con que en la información intervengan tres testigos, y se haga ante Escribano y Juez, que no han de levar derechos algunos...".

La posible explicación de la contradicción entre lo prevenido en la Nueva Recopilación y en la Novísima, puede estar en que, por un lado, la 1.7, tit.19, lib. $5^{\circ}$ de la Novísima recoge textualmente la Ley 25, tit. 12, lib. 1 de la Nueva; por otro lado, en que el señalado párrafo 83 tiene el origen en una Real Cédula de Carlos IV, de 23 de Julio de 1794, e instrucción inserta de 28 de Junio anterior.

La Ley 11 que contiene el meritado párrafo 83 dice: "Nuevas reglas sobre el uso del papel sellado en los autos, escrituras e instrumentos públicos", y en una pequeña "Exposición de motivos" aclara la necesidad de incrementar el precio del papel sellado, en base a la urgencia por conseguir fondos extraordinarios. Nada tiene pues de extraño que esa necesidad incremente también las garantías respecto de los requisitos para declarar (obtener) la pobreza. Téngase en cuenta asimismo que no se trata del único caso de duplicación de normas, con igual o diferente cotenido.

Alonso DE VILLADIEGO Y VASCUÑANA al tratar del "Pedimento de muger casada, pidiendo su dote al marido que va empobreciendo", señala la prueba testifical como medio de acreditamiento: "...Probarse la pobreza del marido en este caso, contra él, ó contra otro extraño, sobre la restitución de la dote, durante el matrimonio, no basta que el testigo diga: se que R. va empobreciendo, sino que conviene que diga: es manifiesto, público y notorio, que va empobreciendo... Y es de notar que si la pobreza del marido proviene de algún hecho que tenga la causa sucesiva, que en tal caso los vezinos son legitimos testigos, y mejores que los extraños, porque se presume que saben mejor los hechos del vezino... En resolución, como esta dicho, para probarse, que el marido no tiene bastante para el pago de la dote, basta y que conteste desto por opinión del vulgo, y de los vezinos" (19).

III.- 6. a) Designación de Abogado o "vocero" o asunción, en el momento histórico ya determinado, de tal tarea por Oficiales de la Administración Central.

b) Exención de derechos, que, a su vez, implica diferenciar:

- 1/ "Salarios" de Abogado-procurador (recogido tempranamente en la legislación, entre otras, en la mencionada Ley XX de las de Estilo)y

- 2/ de Juzgador y oficiales regios relacionados con el proceso (escribanos, relatores, etc), solo modernamente con carácter general se dictan normas en este sentido.

- 3/ otros que examinaremos a continuación (papel sellado, etc.).

La manifestación más antigua que hemos encontrado con respecto a la exención de derechos en beneficio de los pobres se remonta a las Cortes que Pedro III reúne en Barcelona en 1283. En la petición XI se contiene que a pobres y ódenes (religiosas) se les dan cartas de ejecución de justicia y las citaciones, sin que paguen nada por ello ("Item quod de carta simplicis justicie execucionis justicie et comissionis det quilibet singulares quinque solidos et non amplius, et universita decem solidos, et pro citacione dentur duo solidos; et littere huiusmodi dentru Episcopis prelatis et 
baronibus de factis eorum propiis, si presentes in Curia fuerint, et pauperibus et ordinibus qui proprium non habent sine precio. Et de littera seu carta alonfamenti, de qua consueverant dari quincuaginta solidos per mille in anno, dentur viginti solidos. Et ita secundum magis et minus volumus observari").

Estimamos que el texto últimamente citado está imbuido de profundas raíces del nuevo derecho que en esa época, y en Cataluña, no solo se ha "recibido" sino que se adopta y alcanza plena vigencia de hecho (20).

Como más arriba ya indicamos, la exoneración de gastos por defensa judicial del pobre se recoge tampranamente en la legislación; así, en el mencionado pasaje de las Cortes de Valladolid de 1312 con Fernando IV, el Procurador-Fiscal no debe llevar nada por su defensa y más aún, se contiene en la propia petición 23 una cláusula penal para los que contravengan tal prohibición. También en la Ley XX de las de Estilo.

En cuanto a la exención de gastos procesales, hasta la puclicación de la Nueva Recopilación de 1567, no puede hablarse de una cierta articulación de este principio. En la Nueva Recopilación son variadas las referencias a la "no toma de derechos" a los pobres, correspondiéndose con determinados preceptos más tarde recogidos en la Novísima Recopilación.

- En la Ley 28, tit. 5, lib. 2 (Nueva Recop.): "Que el Presidente y Oidores no se dilaten por culpa de Letrados y Procuradores los pleytos de los Pobres, y que no se les lleue derechos". Esta norma pasará a la Novísima Recopilación como 1.30, tit.1, lib. $5^{\circ}$.

- En la 1.28, tit. 8, lib. 2 de la Nueva Recop., en el fol. 117, $1^{\text {a }}$ col. "in fine", se recoge que "...a los pobres se les den los registros sin derechos...". Esta Ley no pasa a la Novísima.

- El Título XIII del lib. $1^{\circ}$ de la Nueva Recop. recoge de manera sucesiva cuatro importantes leyes en esta materia:

- Ley 20: "Que a los pobres presos, jurando serlo, no los detengan, ni les tomen los vestidos por razón de derechos". Estos derechos son los de "las justicias, y escribanos y carceleros..."; se especifica además que "ni se les tomen las capas, ni ropas, ni sayos, ni sayas, y mantos y otros vestidos que truxeren, y se les bueluan, si los huuieren dado en prendas de los dichos derechos, sin lleuarles cosa alguna por razon de los dichos derechos...". Se agrega además una cláusula penal "...y que el carcelero, o alguazil, o escriuano, o otra persona, que lo contrario hiziere, incurra en pena por cada vez un ducado para los pobres de tal carcel, y de suspensión del oficio que tuuiere por un mes. Y mandamos a las justicias, que tengan especial cuydado de haber si se cumple lo susodicho, y de executar las dichas penas en los que no complieran".

- Ley 21: "Que los condenados en setenas, pobres, no sean detenidos por los derechos, y costas, aunque otros paguen por ellos las setenas". Se aplican las penas de la Ley anterior (21).

- Ley 22: "Que a los pobres, executada en ellos pena corporal, no los bueluan a 
la carcel por derechos" (aludiendo a los derechos de las justicias, escriuanos y carcelero). También contiene esta norma para los transgresores (22).

- Ley 23: "Que los derechos de los oficiales, no los paguen los pobres, ni les compelan a que den fiador ni se paguen de las limosnas que les hizieren; que los oidores y las justicias castiguen, y executen las penas a lo que los lleuaren (23).

Todas estas leyes pasan correlativamente a la Novísima Recopilación de 1805, con los números 20 a 23 del tit. 38 , lib. 12 .

En la Ley 17, tit. 2, lib. 3, también de la Nueva Recopilación, se estatuye que los pleitos de los pobres se vean los sábados y que los que hubieren hechos "solemnidad", ni escribanos ni relatores les lleven derecho alguno, bajo pena del "quatrotanto" para la Cámara real.

La Ley 57, tit. 4, lib. 3ㅜㅗㅇ asimismo de la Nueva Recop., y también respecto de los pobres, acoge el mandato dirigido a los Alacaldes Mayores de los Adelantamientos para que "...hagan comprar camas para los presos pobres, y limpiarlas y renovarlas a sus tiempos...".

En los Capítulos de Corregidores -según recoge Alonso de VILLADIEGO- se les previene para que "...despachen primero, y con brevedad al pobre... y al huerfano, y a las personas miserables. y brevien los terminos maliciosos que las partes suelen pedir..." (24).

Asimismo, según prescribe la Nov. Recop., en su parágrafo $82,1.11$, tit. 24, lib. $10^{\circ}$ "A todos los pobres de solumnidad se les permite que en lo judicial usen del papel del sello quarto, con que mas que cuatro maravedies de cada pliego entero, y dos maravedies de cada medio pliego; y en lo que han de servir para esta efecto, se ha de poner la inscripción siguiente: "Para pobres de solemnidad": Porque no puedan servir para otra cosa".

Junto a tales "Beneficios" que implica el reconocimiento de la pobreza, puede destacarse, por el contrario, una serie de "limitaciones" entre las cuales destacan las siguientes respecto a ser parte como acusador y a ser testigo:

A.- Con respecto a la posibilidad de que el pobre pueda ser acusador:

- Ya PILLII MEDICINENSIS (en su "Summa de ordine iudiciorum") citando el D. 48. 2. 8: dice "Si sabemos quienes pueden acusar, entenderemos quienes no pueden hacerlo. En efecto, si impide que lo hagan, unos... D. 48. 2. 10" otros por su pobreza, como son los que tienen menos de 50 aúreos (25).

- En la 1.2, tit. 1, de la Séptima Partida, se ve notablemente disminuida para el pobre la posibilidad de ser parte de un procedimiento por cuanto expresamente se le prohíbe ser acusador "...si non ha la valia de cincuenta marauedies..." ("Acusar puede todo ome que non es defendido por las leyes deste nuestro libro. E aquellos que non puedan acusar, son estos: la muger e el moço que es menor de catorce años, e el alcalde, o merino... E aun dezimos, que aquel que ouiesse fechas dos acusaciones, non pueda facer la tercera, fasta que sean cabadas por jyzio las primeras. Otrosi dezimos, que ome que es muy pobre, que non ha la valia de cincuenta marauedies, non pueda facer acusación...". En idéntico sentido HEVIA VOLAÑO dice que "los prohibidos de ser acusadores son... el que es muy porbre..." (26). 
El origen de esta prohibición impuesta al pobre que tenga menos de cincuenta maravedíes, encuentra su antecedente en Digesto 48. 2. 10. (hermogeniano, 6: "iuris epitomarum", "...nonnulli propter paupertatem, ut sunt qui minusquam quinquaginta 'aureos' habent", como destacó la literatura jurídica intermedia.

Frente a tan radical prohibición de acusar, autores como Julio CLARO defienden que no obstante tal limitación no operará si es de fe y vida honesta y fiel y si se trata de perseguir "injurias propias" ("...quod si talis pauper est bonae et honestae fidei et vitae non suspectus propter paupertatem non repellitur ad accusando" (27). Asimismo, sigue diciendo Julio CLARO: "...si suam vel suorum iniuriam prosequatur" (28).

B.- Con respecto a la posibilidad de que el pobre pueda ser testigo, PILLII MEDICINENSIS (P. 3, pargrf. 8) dice:

"Illud nempe sciendum est diligenter in testibus, utrum sint locupletes vel egentes, et an mimiei ei, adversus quem producuntur, vel amici ei, pro quo inducuntur, ut Dig. e. t. $22,5.1 .3$ (pr); nam intimus amicus proferentis et valde inimicus eius, contra quem inducitur, omnimo repellitur; et sic intelligo legem illam et Cod. e. t. 4, 20, L. si quis, 17. ciertamente debe conocerse diligentemente este en los testigos, si son ricos o pobres, o si son enemigos de aquél contre el que son presentados, o amigos de aquél a favor del que deponen (como D. 22. 3. 52, pr; pues el íntimo amigo que le lleva, y el muy enemigo de aquél contra el que depone, deben ser rechazados completamente..." (23), añadiendo además el autor: "Propter paupertatem repellitur quis. Ut in Auth. t. e. \& 1. (Nov. 90 c. 1. \&. 1) Sed pauperem hic intelligo illum, qui habet minus quinquaginta aureis. arg. Dig. de accusat. 48, 2 1. nonnulli 10. Pauperes autem interdum admittuntur si sunt bonae famae, opinionis et idei; non enim tam facultatibus quam fide testis idoneus aestimari potest arg. Inst. de suspect. tut, 1, 26, \& ult. et in Auth. e. \&. 1 (Nov. 90. c. 1 \&1). Verum quandoque et egens et locuples repellitur, puta si lucri causa aliquid facile admiserint ut Dig. e. t. 22, 5, 1. 3 (pr.) Item testimonium, ut sic admittendum, care e debet suspicione, et propter personam, a qua fertur, quod sit honestae el bonae famae, item propter causam, puta quod nequegratiae, aut lucri, aut inimicitiae cause sit ut Dig. e. t. 22, 5. 10 1. 5. (pr.).

En Novell, 90 c. 1.1 (30). Pero además, aquí entiendo por pobre aquel que tiene menos de 50 aureos, (arg. en D. 48. 2. 10). En cambio, a veces son admitidos los pobres si son de buena fama, reputación y credibilidad; pero se les puede considerar testigos idóneos, no tanto por sus recursos sino por su credibilidad (Inst. 1. 26, 13) (Novell. 90, c. 1,1) Pero a veces el rico y el pobre son rechazados porque se piensa que pueden admitir fácilmente algo a causa de lucro (como D. 22. 5. 3). En todo caso, este autor (p. 3, \& 13 "De la credibilidad de los testigos") dice tajantemente que es más creíble el rico que el pobre ("...item magis diviti quam pauperi") (31).

En el mismo sentido se pronuncia TANCREDI BONONENSIS, afirmando en primer lugar: Prohibentur etiam pauperes a testimonio, tam iure fori, quam iure poli ut C. 2. q. 1. c. imprimis 7. (\&3), et I, prohibentur (c. 14) et in Auth de testil \& 4 (Nov. 90 c. 1) Et dicunt quidam, hoc obtinere in criminalibus causis dumpta at, et 
generaliter obtinere de quibuslibet pauperibus, qui minus quam quinquaginta aureos habent. Mili videtur hoc dictum esse de his pauperibus tantum, qui obtentu pecuniae praesumuntur supprimere veritatem; quoniam si testis est honestus ita quod nulla praesumptio sit contra eum, ut pro pecunia menfiatur, licet pauper cit, pauper sit, non est repellendus a testimonio; alioquin enim oporteret dici multos sanctos et viros religiosos et etiam ipsos apostolos a testimonio repellendos, que pauperes sunt nihil habentes", y concluyendo después que "Item rotius credendum est veidico quam mendaci emndato quam luxurioso, magis diviti quam pauperi" (32).

Con respecto a la posibilidad de que el pobre pueda ser testigo, en la Ley VIII, tit. VII, li. IV del Espéculo, se determina: "...E dezimos que los pobres de que dixiemos en la Ley ante desta, que non podrien testiguar, que por estos se deve á entender é non por otros, asi como aquellos que non an en su valia en mueble e en rayz de veynte mrs. arriba, con todo esto que son de mala vida. Mas si fuere conoscido por de buena vida, e que non aya sospecha contra el, que dixiese falso testimonio por aver nin por otra cosa, nol pueden desechar por esta razon que nos sea testigo". Asimismo, en la Ley 8, tit. XVI, de la $3^{\mathbf{a}}$ Partida: "Todo ome de buena fama e... puede ser testigo. E aquellos a quien es defendido, son estos...nin ome muy pobre, e vil...".

La literatura acogió también esta limitación para ser testigo, entre otros, AYLLON LAINEZ (33), FARINACCI, etc. Este último dice: "...quod inste testis est vilis pauper et abiectus quo causa criminalibus non recipitur secundum communem... Vbi enim cum paupertate testis concurrit etiam vilitas tunc non solumm non est idoneus testis sed etiam a testificando repellitur..." (34). Julio CLARO mantiene que para la mayoría de los autores, el pobre no puede ser testigo, aunque para algunos es una cuestión que queda al arbitrio judicial (35).

Se les reconoce a los pobres, muy cuitados y desvalidos, fuero especial, particularmente en las "alçadas". Que de las "alçadas" y de los otros pleitos que hayan de resolverse en la Corte juzge el Tey: "Biudas, o juerfanos, si ouieren alçadas, o otros pleytos, porque hayan de venir a la Corte del Rey, el los deue judgar... Esso mismo dezimos de los otros que son tan pobres, que non ha valia de veynte marauedies...Otrosi dezimos, que por si querella de alguno mandare el Rey a otro por su carta, que oya aquel pleyto de que le querellaron, o que le judgue; si alguna de las partes se agrauiare de su mandamiento, o de su jyzio, non se due alçat a otro ninguno, fueras al Rey que lo mando fazer" (Ley 20, tit. 23, Partida 3ä; en Nueva Recop., Ley 10, tit. 4, lib, 11).

III.- 7. Sobre la pobreza de las personas jurídicas. No solo gozan del beneficio de pobreza las personas físicas, sino que también se les reconoce este derecho a determinadas personas jurídicas. Así, en este sentido, los Reyes Católicos por Pragmática de 1502 y Felipe II en 1554 (sancionadas en la Novísima Recopilación, Ley 5, tit. 35, lib. 11), "Mandamos a los de nuestro Consejo y Oidores de las nuestras Audiencias, Alcaldes, Notarios de nuestra Casa y Corte y Chancillerías...Secretarios y Escribanos de nuestra Audiencias y otros qualiesquier juzgados, y otras qualesquier personas no consientan llevar ni lleven derechos algunos a los Monasterios de la Orden de San Francisco y de San Agustín, y Santo 
Domingo y del Carmen, que estan reformados en Observancia, de qualquier Orden que sean, de qualesquier mercedes y limosnas, ni privilegios, ni cartas, ni provisiones, ni procesos ni otros autos algunos; y los dichos nuestros Contadores ni Secretarios, ni Escribanos de Cámara y Escribanos de nuestras Audiencias ni otros oficiales, no los pidan ni lleven en manera alguna: y que los otros Monasterios de las otras Ordenes que estan reformados, o se reformaren de aqui adelante, que no paguen derechos algunos de las cartas, y provisiones y privilegios que sacaren, ni del sello ni del registro, estando en regular Observancia...".

Por decreto del Consejo de 14 de Agosto de 1782, con motivo de haber pretendido el General de la Orden de S. Juan de Dios, que "a consecuencia de lo declarado en esta Ley, se librase de provisión, para que en todos los Tribunales se ayudase a defendiese por pobres a las Casas de su Orden, sin exigirles derechos algunos; se denegó esta solicitud conformándose el Consejo con lo expuesto por su Fiscal, fundado en que, al tiempo de la promulgación de la Ley del año 1502, no tenían bienes los Monasterios reformados, y después, por el Concilio de Trento en el año 1563, se les habilitó para poder adquirirlos y tenerlos, como los tenían, cesando por consiguiente la concesión de ayudarlos y defenderlos por pobres, con la cesación del motivo de ella".

También, por Autos del Consejo de 14 de Septiembre de 1774 y 4 de Mayo de 1775 , en pleito seguido por los administradores del Hospital de Santa Cruz de Barcelona sobre la pertenencia de ciertos bienes, "enel qual se defendieron por pobres, y obtuvieron providencia definitiva a su favor, se mandó que de dichos bienes pagasen el relator y Escribano de Cámara sus respectivos derechos de relación y executoria".

Asimismo, por otro Auto del Consejo de 14 de Enero de 1792, "en pleyto seguido por el Hospital de pobres incurables de Córdova sobre la subsistencia de una vinculación hecha a su favor, en el cual se defendió por pobre conforme a lo dispuesto en dicha Ley (1.5, tit. 35, lib. 11, Novís. Recop.), y obtuvo executoria, se mandó que esta se despachase sin perjuicio de los derechos de ella pertenecientes a la Escribanía de Cámara".

Al igual que con los pleitos de pobres, en la Nueva Recopilación (1. 17, tit. 2, lib. 3), se previene que "...los sabados se vean pleitos de pobres y libertades, y hospitales y monasterios, e Iglesias".

IV.- 8. Aunque con clara inspiración en las fuentes iuscanonistas, como sucede en general, fruto de la recepción jurídica romano-canónica, en España cabe hablar históricamente de una gran preocupación sobre el tema. Tal preocupación cristalizó en institutos diferentes y en regulaciones diversas, según habrá podido apreciarse en la esquemática exposición realizada. De la misma, podría concluirse que, pese a las distintas fuentes (disposiciones normativas, opiniones doctrinales, decisiones de Cortes, etc.) de que nos hemos servido -en todo caso, decisivas a la hora de comprender la configuración histórica de la Justicia gratuita-, todas ellas han contribuido de manera decisiva junto a una "práctica forense" de la que esporádicamente se tienen noticias, a comformar una base bastante sólida expresiva de la importante y generalizada preocupación sobre el tema, base que sirvió de oportuno fundamento a 
la legislación decimonónica procesal, sobre todo a la Ley en Enjuiciamiento Criminal de 1872, compilación de 1879, Ley de Enjuiciamento Criminal de 1882 y Ley Enjuiciamiento Civil de 1881, en gran parte vigentes, sin perjuicio de las modificaciones introducidas en esta última por la Ley de 34/84 de 6 de Agosto.

\section{BIBLIOGRAFIA}

AYLLON LAINEZ, I. De Vtrariensis illustrationes sive additiones eruditissimae ad varias resolvtiones Antonii Gomezii, Lvgduni, sump Fratrum Anissoniorvm, \& Ioannis Posvel, 1626.

CALDARA, E y CAVAGNARI, C. Avvocatura dei poveri, en Digesto italiano, IV, 2, Torino, 1893-1899. También en Avvocatura dei poveri, en Novissimo Digesto italiano, I, 2, Torino 1958.

CAPPELLETTI, M. "Pobreza y Justicia", en Proceso, ideología y sociedad, Buenos Aires, 1974; y también en la edición italiana, "Povertá e Giustizia", en Giustizia e Societá, Milano, 1972.

CARRARA, F. Il passato, il presente e l'avenire degli avvocati in Italia, Lucca, 1894.

CLARI, J. Opera omnia, sive practica civilis atque criminalis, Lugdunim sumpt. Horatii Boissat \& G. Remevs, 1661.

DENTI, V. Processo civile e giustizia sociale, Milano, 1971.

FARINACII, P. Consilia, sive responsa arque decisiones causarum criminalium, Lvgdvni, sumpt. Horacii Cardon, 1607.

FIGUERUELO BURRIEZA, ANGELA El derecho a la tutela judicial efectiva, Madrid, 1990.

GONZALEZ PEREZ, J. El derecho a la tutela jurisdiccional, Madrid, 1984.

HEVIA VOLAÑO, I. Cvria Philippica, Valladolid, 1609.

LALINDE BADIA, J. Iniciación histórica al Derecho español, Barcelona, 1970.

OLIVA SANTOS, ANDRÉS DE LA, Sobre el derecho a la tutela jurisdiccional, Barcelona, 1980.

ORTIZ DE ZÚÑIGA, M. Biblioteca judicial o tratado original y metódico de la organización y atribuciones de los Juzgados de primera instancia de las Audiencias y del Tribunal Supremo de Justicia, Madrid, 1849, 3 tomos; del mismo, Práctica general forense, Madrid, Vda de Jordán e hijos, 1870, 3 tomos.

PEREZ DE LA CANAL, La Justicia en la Corte de Castilla durante los siglos XIII al XV, Historia, Instituciones, Documentos, Sevilla, 1975.

PILLIUS, TANCREDUS, GRATIA, Libri de iudiciorum ordine, Herausg, F. ch. Bergmann, Neudr, der Ausgabe, Goettingen, 1842, Aalen, 1965.

SERRANO ALBERCA, J.M., y otros, Comentarios a la Constitución, Madrid, 1980.

VILLADIEGO VASCUÑANA, A., Instrucción política y práctica judicial, Madrid, imp. Geronimo Roxo, 1729.

\section{NOTAS}

(1).- No entro lógicamente en un análisis de este Derecho a la tutela judicial efectiva, que está dando lugar a numerosos trabajos de investigación, principalmente por juristas, así, vid. entre otros muchos, los de SERRANO ALBERCA, J. María, "Comentario al artículo 24,1 de la C.E.", en Comentarios a la Constitución, dirigidos por Garrido Falla, Madrid, 1980, GOMEZ-FERRE MORANT, Rafael, "Derecho a la tutela judicial y posición jurídica peculiar de los poderes públi- 
cos", en Revista Española de Derecho Administrativo, 1982, núm 33, Abril-Junio, págs 183 y ss, OLIVA SANTOS, Andrés de la, Sobre el derecho a la tutela jurisdiccional, Barcelona, 1980, GONZALEZ PEREZ, Jesús, El derecho a la tutela jurisdiccional, Madrid, 1984, FIGUERUELO BURRIEZA, Angela, El dercho a la tutela judicial efectiva, Madrid, 1990, etc.

(2).- Sobre la doctrina del Tribunal Constitucional en tomo al derecho a la Justicia gratuita, entre otras muchas, es factible citar la sentada en su sentencia de 25 de Enero de 1983.

(3).- Sobre este instituto vid. CALDARA, E. y CAVAGNARI, C., Voz "Avvocatura dei poveri", en Digesto italiano, IV, 2, Torino, 1893-1899, esp.pp. 712 y ss, también Voz "Avvocatura dei poveri" en Novissimo Digesto italiano, I,2, Torino, 1958, pp 183 y ss.

(4).- Así, CAPPELLETTI, M., "Pobreza y Justicia", en Proceso, ideología y sociedad, Buenos Aires, 1974, p 156 y ss., edición italiana, "Povertá e Giustizia", en Giustizia e Societá, Milano, 1972 , p 237 y ss.

(5).- FERRARIS, "statu ecclesiastico", en Biblioteca canonica, Voz "Advocatus", n. 24-27, cit. en Novissimo Digesto italiano 1958, op. cit.

(6).- CAPPELLETTI, M. ops. ctis. respectivamente en pp 157 240-241.

(7).- Más ampliamente en DENTI, V., Processo civile e giustizia sociale, Milano, 1971, p. 137 y ss.

(8).- DENTI, V., Le ideologie del processo di fronte al problema sociale, en Processo civile e giustizia sociale, op. cit, $\mathrm{p} 22$.

(9).- Esto es gratamente comentado por CARRARA, F., Il passato, il presente e l'avvenire degli avvocati in Italia, Lucca, 1894, p. 5 y ss.

(10).- También, Leyes 19 y 22, tit 9, p.2 Proemio., Leyes 11 y 12, tit, lib 4 del Espéculo.

(11).- Cortes de Valladolid de 1312, 23, Cortes I p. 203, que plasmaron las Ordenanzas de 1310, ed. Benavides, en Memorias de D. Fernando IV de Castilla, vol II, doc DX p. 735; en la edición de las Cortes de Valladolid de 1312, p. 203 se dice: "...Otrossi tengo por bien de auer vn procurador que demande é rrazone é deffienda por mi los mios pleytos é los de las biudas pobres é de los verffanos... é que non tomen nada de los poures".

(12).- Como "caso de corte" es recogido por PEREZ DE LA CANAL, La Justicia en la Corte de Castilla durante los siglos XIII al XV, Historia, Instituciones, Documentos., Sevilla, 1975, p. 397-8.

(13).- Cortes de Zamora de 1274, 3 Cortes, I, p. 88.

(14).- Ordenanzas Reales de Castilla, II, 12, I. También Cortes de Briviesca de 1378, 30, Cortes, II, p. 389, esp. peticiones 18 a 31 y correspondientes respuestas.

(15).- Ordenanzas Reales de Castilla, II, 4, I.

(16).- HEVIA VOLAÑO, I, Cvria Philippica, Valladolid, imp. Iuan Godinez de Millis, 1609 , parág. 9, núms. 13 y ss, p. 143-44.

(17).- VILLADIEGO VASCUÑANA Y MONTOYA, A. Instrucción política y práctica judicial, Madrid, imp. Geronimo Roxo, 1729, fol. 26.

(18).- Como recogen ORTIZ DE ZUÑIGA Y HERRERA, Deberes y atribuciones de los Correjidores, Justicias y Ayuntamientos de España, IV, Madrid, 1832, p. 167-8, citando las Leyes 10 , tit. 6, Partida 3 y 13 y Ley 11 y s. del tit. 22, libro 11 de la Novísima, que "Según el juramento que presta todo abogado antes de recibir el tútulo, y lo que prescriben las leyes, tienen la obligación de defender las causas de los pobres de gracia, y sin retribución alguna, en los pueblos donde no hubiere letrados asalariados para este objeto, a menos que no los puedan defender por algún impedimento lejítimo: y tanto los abogados como los demás curiales deben encargarse de promover la justicia en las causas de oficio, trabajando en ellas sin interés alguno, cuando los reos carecen de facultades para satisfacerles sus honorarios, no solo en las causas contra paisanos, sino en las que se sigan contra militares" (en este último sentido, los autores mencionados citan Acuerdo del Consejo de la Guerra de 4 de Enero de 1828).

(19).- VILLADIEGO VASCUÑANA, A. Instrucción política y... (ver nota 17). 
(20).- En este sentido, tal vez pueda interpretarse como expresión de la adaptación producida en el derecho catalán y la elaboración doctrinal que se origina en Castilla, sin que se haya verificado el salto del tratamiento doctrinal a la incorporación a la legislación de las Cortes. Vid. a este tenor a LALINDE ABADI, J. Iniciación histórica al Derecho español, Barcelona, 1970, p. 810.

(21).- Ley 21 , tit. XII, lib. $1^{2}$ Nueva Recopilac.: "Porque acaece, que algunos presos son condenados en penas de setenas, $y$ defecto de no pagar en pena corporal, algunos parientes, $o$ amigos $o$ otras personas, pagan por ellos las dichas setenas, que haciendo juramento que son pobres, y que no tienen de que pagar las costas, y derechos de la justicia, y escriuanos, y carcelero, no sean detenidos por ello, y luego les suelten: y el que en contra lo susodicho viniere, incurra en las penas contenidas en la Ley precedente".

(22).- Ley 22, tit. XII, lib. $1^{2}$ Nueva Recop.: "Mandamos, que de aqui adelante, quando alguna persona pobre fuere condenado en pena corporal, siendo en ellas executada la pena, non los tornen por la dicha causa a la carcel; ni por razón de los derechos de las justicias, y escriuanos, y carcelero: y que luego donde se cabare la execucion, lo suelten libremente, si no huuiere otra causa porque deuan tornart a la carcel; y que a los dichos pobres, siendo condenados en pena de destierro, que queriendo salir a los cumplir, luego los suelten, ni los detengan por razon de los dichos derechos, lo qual cumplan las justicias y oficiales".

(23).- Ley 23, tit. XII, lib. $1^{\circ}$ Nueva Recop.: "Otrosi, porque acaesce que alguno de los dichos pobres son oficiales, y procuran que otro de su oficio se obligue a pagar las costas, y derechos por ellos, y de otra manera no los quieren soltar, y asimismo de lo que se les da por limosna para pagar sus condenaciones, quieren ser pagados de los dichos derechos: mandamos, que de aqui en adelante no se haga assi, ni apremien a los dichos pobres que den fiador, ni sean pagados de las dichas limosnas, sino constando que son pobres y no tienen otros bienes, no esten presos por razón de las costas, y derechos de las justicias, y de alguaziles..."

(24).- VILLADIEGO VASCUÑANAN, A., Instrucción política y práctica judicial, ver notas 17 y 19.

(25).- PILLII MEDICINENSIS, Summa de ordine iudiciorum, p. $3 \& 8$ ("De testibus") en Libri de iudiciorum ordine (PILLIUS, TANCREDUS, GRATIA), herausg. v. F. Ch. Bergmann, Neudr, der Ausg. Gottingen, 1842, Aalen, 1965, p. 64.

(26).- HEVIA VOLAÑO, I. Cvria philippica, cit. III parágrf. 8, p. 562.

(27).- CLARI, I., Opera omnia sive practica civilis atque criminalis, Lugduni, sumpt. Horatii Boissat et G. Remevs, 1661, n. 19, fol. 439.

(28).- CLARI, I., op. cit. quaestio XIV, n. 40, fol. 128.

(29).- PILLII MEDICINENSIS, op. cit. p. 64.

(30).- PILLII MEDICINENSIS, op. cit. p. 65.

(31).- PILLII MEDICINENSIS, op. cit. p. 72.

(32).- TANCREDI BONONENSIS, Ordo iudiciarius, p. 3, tit. 12, en Libri de iudiciorum ordine, op. cit. p. 225 y 246.

(33).- AYLLON LAINEZ, I. de, Vtrariensis illustrationes sive additiones ervditissimae ad varias Resolutions Antonii Gomezii, Lvgduni, sump. frates Anissoniorum \& Inoannis Posuel, 1626 , fols. 243 y ss.

(34).- FARINACII, P. Consilia, sive responsa atque decisiones causarum criminalium, Lvgduni, sumpt: Horatij Cardon, 1607, Consilium XXII, n. 27, folio 106.

(35).- CLARO, J. op. cit. quaestio XXIV, n. 11, folio 459. 


\title{
REFLEXION SOBRE LA AUTONOMIA ORGANIZATIVA MUNICIPAL COMO LIMITE A LA POTESTAD LEGISLATIVA AUTONOMICA (ACERCA DE LA SENTENCIA 214/1989 DEL TRIBUNAL CONSTITUCIONAL)
}

\author{
JUAN ROSA MORENO
}

Antes de la entrada en vigor de la actual Constitución era claro que no gozaban los municipios, en la materia objeto ahora de atención, más que de una potestad reglamentaria "hacia el interior", rotulándola, si se quiere, como potestad organizatoria, considerada la organización como uno de los aspectos donde los reglamentos actuaban, y concebida como posibilidad inherente a toda reorganización de desarrollar la estructuración fijada en las leyes y reglamentos estatales. En efecto, la jurisprudencia construía la naturaleza de la potestad de organización como postestad consustancial a la Administración, siendo una extensión de la potestad reglamentaria (1). Con la aprobación de la Carta Magna, con la posterior publicación de la Ley $7 / 1985$, y con la doctrina sentada por el Tribunal Constitucional en la Sentencia que se comenta, la potestad autoorganizatoria municipal se consagra, se eleva y, por último, se configura nuevamente.

Sabido es que en el Derecho local se distinguen con total nitidez dos tipos de fuentes, las autónomas y las heterónomas, la posición de las mismas en el sistema varía según sea el aspecto sustantivo de que se trate (2). Pues bien, en cuanto al régimen organizativo, la Ley $7 / 1985$ estableció una prelación de fuentes que situaba al Reglamento orgánico municipal de forma tal que desplazaba a la legislación autonómica a una posición subsidiaria. La Ley básica articulaba, en este sentido, la intención del legislador expresada en su Preámbulo (3), distinguiéndose entre la conformación de la organización territorial, donde el interés autonómico debe primar, y la organización interna de las entidades municipales, aspecto donde se debe anteponer el interés local.

Los límites normativos de la potestad autoorganizatoria municipal eran fijados, pues, exclusivamente por la legislación básica del Estado (4). El Tribunal constitucional viene a suprimir este sistema instaurado por el legislador estatal, al establecer tres espacios normativos y al ubicar la potestad autoorganizatoria municipal en el último de ellos, potestad que califica como de reglamentaria, encontrando, conforme al criterio del Alto Tribunal, un óbice insalvable en la legislación autonómica, esto es, el principio de jerarquía normativa.

El juego de los apoderamientos competenciales derivados del bloque constitucional en materia de organización municipal, configura el objeto sobre el que recae 
el esfuerzo hermeneútico del Tribunal Constitucional. En efecto, es consolidado el iter interpretativo que lleva al Tribunal a incardinar el régimen organizativo municipal dentro de la rúbrica de "régimen local", y a ésta dentro del título competencial de "régimen jurídico de las Administraciones Públicas". El régimen local es, por tanto, el régimen jurídico de las Administraciones locales (5). Siguiendo la argumentación fijada, la habilitación estatal para establecer los criterios básicos de la organización municipal es claro: artículo $149,1.18^{\circ}(6)$. La problemática, pues, se va a circunscribir a las habilitaciones competenciales de las Comunidades Autómomas, en un doble sentido, el primero conectado con la efectiva operatividad de la autonomía organizativa municipal, y el segundo derivado de la distinta gradación que los Estatutos confieren a las competencias autonómicas en materia de régimen local.

Con posterioridad a la vigencia de nuestro Texto fundamental, han sido notables los aportes de la doctrina española al concepto de autonomía local (7). Por otro lado, la conflictividad que se aborda fue ya anunciada por MARTIN MATEO en 1980 (8), y expresada de forma gráfica por PAREJO ALFONSO en 1983 (9).

Es cierto que la concreta configuración institucional de la autonomía local corresponde al legislador (10), también es cierta la afirmación según la que no se atribuye, en exclusividad, esa fución configuradora ni al legislador estatal, ni al legislador autonómico (11). Si ello es así, la fijación por aquél de las condiciones básicas no puede implicar el forzoso uniformismo local. Queda, en todo caso, a salvo la potestad normativa de las Comunidades Autónomas (12). Claro está, esta legislación vendrá limitada por la garantía constitucional de la autonomía local, garantía que, innecesario parece decirlo, opera también con respecto al legislador estatal.

Precisamente, la incardinación de la potestad autoorganizatoria municipal, o más bien de los Reglamentos orgánicos como manifestación más genuina de la misma (13), inmediatamente después de la legislación básica del Estado, únicamente puede realizarse mediante una interpretación de la autonomía local que conlleve la concepción de la postestad de autoorganización como integrante de esa garantía institucional, $\mathrm{y}$ al régimen organizativo de los entes municipales como un materia donde el interés propio de la entidad la convierte en reducto indisponible del legislador autonómico.

Mientras de la primera concepción simplemente puede apuntarse, sin más, que está pacíficamente aceptada por la doctrina (14), no encerrando per se ningún trastocamiento en la tradicional prelación de fuentes; de la segunda de las interpretaciones mencionadas hay, obligadamente, que hacer un alto en la senda, ya que su afirmación propicia una construcción del sistema de fuentes tal y como fue positivizada por la ley básica, y su negación hace sostener una elaboración como la realizada por el Tribunal Constitucional.

Opiniones dictrinales al respecto fueron ofrecidas desde las ópticas posibles. Así, para MARTIN MATEO (15), en materia de organización municipal no opera el binomio legislación básica estatal-legislación autonómica de desarrollo, la autonomía local impide, aquí, toda injerencia por parte de las proposiciones de las 
Comunidades Autónoma. Para FERNANDEZ FARRERES (16), si se otorga primacía a la legislación autonómica en materia de organización intema municipal, sobre la producción normativa local, podría con ello vaciarse de contenido a la potestad autoorganizatoria, vulnerando la propia autonomía local. En sentido contrario a los anteriores pronunciamientos, COSCULLUELA NONTANER (17) ya señaló, en relación al proyecto de la ley básica, la inconstitucionalidad de la solución adoptada al desconocer el significado y alcance de la potestad legislativa de las Comunidades Autónomas, degradando su valor normativo (18).

A la vista de los silogismos doctrinales y jurisprudenciales se podría llegar a una primera conclusión, esto es, ambas interpretaciones caben dentro del marco constitucional. Falsa conclusión ésta, ya que como todo concepto jurídico indeterminado, la autonomía local al aplicarse a cada supuesto concreto, régimen organizativo en este caso, sólo una de las posibles interpretaciones deviene como correcta, siendo el resto conclusiones hermeneúticas erróneas. Éste es el calificativo que puede predicarse de la posición mantenida por el Tribunal Consititucional (19).

No obstante, miradas a los regímenes alemán y, especialmente, al italiano, permiten al Tribunal deslizar apoyaturas comparadas. En el primero de ellos se ha sustraido del concepto de autonomía local gran parte de su operatividad en el aspecto organizativo (20). Por su parte, en el sistema italiano se ha legislado, en cuanto al régimen organizativo interno municipal, mucho más allá de lo realizado por el legislador español, al institucionalizar órganos de desconcentración territorial municipal (21). Ésto no es, sin embargo, un óbice a la construcción de la autonomía local que aquí se pretende mantener, sino más bien un reto. La doctrina española tiene la oportunidad, perdida por el Tribunal Constitucional, de abogar por una concepción de la autonomía realmente garantísta de los intereses locales, dejando de lado equivocados andamiajes, incluso comparados.

Esta necesaria opción interpretativa que se mantiene, se basa, fundamentalmente, en el críterio del "interés respectivo" (22). La primacía que debe otorgarse, en el aspecto tratado, al interés local (23), hace que el régimen organizativo deba ser una materia en la que la producción normativa heterónoma sea sólo la indispensable, esto es, simplemente la derivada de la configuración del llamado por la doctrina constitucional modelo de Estado. Por lo tanto, aunque se afirme que de la Constitución no dimana una potestad estatutaria municipal, es decir, la posibilidad de dotarse de una constitución interna peculiar y diferente (24), sí que posibilita el dotarse de una estructura interna peculiar y complementaria de ese cañamazo básico (25) que constituye la dosis (26) de uniformismo local implícita en la propia garantía constitucional.

Con la atribución, pues, a las Comunidades Autónomas de un interés dominante sobre el local, se perfilará en exceso el régimen organizativo municipal, derivando, ciertamente, una vulneración del texto constitucional. Esta consecuencia se ve agravada exponencialmente a causa de uno de los principales problemas al que conduce la interpretación del Tribunal Constitucional, esto es, la defensa del ámbito reservado a la autonomía organizativa municipal (27), amparo que corresponde suministrar al máximo intérprete de nuestra Constitución, pero que las Corporaciones locales se 
ven impedidas de estimular a causa de su nula legitimación para interponer los posibles recursos de incostitucionalidad (28) sobre leyes autonómicas que invadan su espacio normativo (29).

\section{NOTAS}

1) Sentencias del Tribunal Supremo de 12 de Noviembre de 1958, de 28 de Abril de 1961 y de 29 de Abril de 1963. Véase José Luis VILLAR PALASI, Apuntes de Derecho Aministrativo, Tomo I, Madrid, 1977, págs. 214 y sigs.

2) Un análisis es el realizado por Luis MORELL OCAÑA, "Las fuentes del derecho local. Problemas generales. Competencias del Estado y las Comunidades Autónomas", en R.E.A.L.A., $1987, \mathrm{n}^{\circ} .235-236$, págs. 489 y sigs.

3) En donde como solución a la dicotomía entre uniformismo y diversidad organizatoria se apunta que "la resolución adecuada a esa tensión exige desde luego la constricción del marco general a lo estrictamente indispensable para satisfacer el interés nacional, pero también desde luego una específica ponderación, según su valor constitucional relativo de las exigencias recíprocas del interés autonómico y el estrictamente local".

4) Con ello la Ley Básica transformaba el tradicional régimen de Carta orgánica en una posibilidad que quedaba en las exclusivas manos de los Ayuntamientos, así Francisco LLISET BORRELL, señaló como a pesar de ser suprimido el régimen de Carta, la legislación básica lo acogía "con mucha mayor flexibilidad y menos trabas procedimentales en su nacimiento". Manual de Derecho Local, Abella, Madrid, 1985, pág. 172.

5) Así en el Fundamento Jurídico Primero de la Sentencia 214/1989 se recoge la doctrina expresada en las Sentencias 25/1983, F.J. 4², 76/1983, F.J. $38^{\circ}$, y 99/1987, F.J. $2^{\circ}$.

6) Véase el Fundamento Jurídico Quinto de la Sentencia del Tribunal Constitucional de 28 de Julio de 1981.

7) Se hace indispensable citar la obra de Luciano PAREJO ALFONSO, Garantía institucional y autonomía locales, IEAL, Madrid, 1981, así como los estudios realizados por: Ramón MARTIN MATEO, "La garantía constitucional de las autonomías locales" en R.E.A.L.A., 1980, no. 208; Antonio EMBID IRUJO, "Autonomía municipal y Constitución: aproximación al concepto y significación de la declaración constitucional de autonomía municipal". en R.E.D.A., 1981, no․ 30; Francisco SOSA WAGNER, "La autonomía local", en R.A.P., 1983, o․ 100-102, Vol. III. Y más recientemente la obra de Miguel SANCIIEZ MORON, La autonomía local. Antecedentes históncos y significado constitucional, Civitas, Madrid, 1990; y por último, el reciente planteamiento elaborado por Francisco SOSA WAGNER, "La autonomía local", en Estudios sobre la Constitución Española. Homenaje al Profesor Eduardo García de Enterría, Tomo IV, Civitas, Madrid, 1991.

8) "No parece dudoso que el Tribunal Constitucional español vaya a conocer de conflictos planteados......... en relación con la distribución de competencias legislativas entre el Estado y las Comunidades $\Lambda$ utónomas en materia de Régimen Local", Ramón MARTIN MATEO, "La garantía constitucional......", loc. cit., pág. 602.

9) "......Surge el interrogante de si el ordenamiento general aparece estruturado en círculos concéntricos (de modo que cl local resulte enmarcado totalmente por el autonómico y éste, a su vez, por el central) o si, por el contrario, lo está de forma más compleja y en términos de círculos secantes (de forma que el ordenamiento local esté limitado directamente tanto por el autonómico 
como por el central)", Luciano PAREJO ALFONSO, Estado social y Administración pública: los postulados constitucionales de la reforma administrativa, Civitas, Madrid, 1983, Pág. 152.

10) Sentencia del Tribunal Constitucional de 27 de Febrero de 1987.

11) Francisco SOSA WAGNER, Manual de Derecho Local, Tecnos, Madrid, 1989, pág. 63.

12) Las Comunidades Autónomas "podrán legislar libremente", señala la Sentencia del Tribunal Constitucional de 28 de Julio de 1981.

13) Ya que también puede manifestarse mediante actos singurales. En este sentido, Luis MORELL OCAÑA, El régimen local español, Tomo I, Civitas Madrid, 1988, pág. 431.

14) Entre otros, Luciano PAREJO ALFONSO, Garantía institucional ......, loc. cit. pág. 154; y Santiago MUÑOZ MACHADO, Derecho Público de las Comunidades Autónomas, Tomo II, Civitas, Madrid, 1984, págs. 67 y sigs. 429.

15) Ramón MARTIN MATEO, "El gobierno municipal", en R.E.A.L.A., 1985, nº. 227, pág.

16) Germán FERNANDEZ FARRERES, "Potestad local de autoorganización: contenido y límites", en vol. col. Tratado de Derecho Municipal, Tomo I, Civitas, Madrid, 1988, pág. 745.

17) Luis COSCULLUELA MONTANER, "Organización y régimen jurídico de las entidades locales. La función pública local", en vol. col. Organización Territorial del Estado (Administración Local), Vol. I, IEF, Madrid, 1985, pág. 135.

18) Apuntar que, con respecto al supuesto italiano, Mario NIGRO se pronunció, asimismo, de forma nítida en favor de un protagonismo regional. "La reforma de la administración local", en D.A., 1981, no. 192, pág. 352.

19) Aunque no todo él. Merece destacar la opinión del Magistrado Eugenio DIAZ EIMIL, de pleno acierto, lástima que en el Boletín de Jurisprudencia Constitucional no se incardine bajo la rúbrica FALLO, sino como simple, pero en este caso plausible, Voto particular.

20) Véanse Otto GÖNNENWEIN, Derecho Municipal Alemán (traducción al castellano de Miguel Saenz-Sagaseta), IEAL, Madrid, 1967; y Ramón MARTIN MATEO, El Municipio en el Estado de Derecho Alemán, Madrid, 1965. págs. 158 y sigs.

21) Un primer análisis doctrinal de la citada legislación -Ley de 8 de Abril de 1976, $\mathrm{n}^{\circ} .278$ fue realizado por Umberto ALLEGRETTI, "I quartieri tra decentramento comunale e autonomia de base", en Rivista Trimestrale di Diritto Pubblico, Giuffré, Milán, 1977, págs, 193 a 266.

22) Criterio que consagra rotundamente el propio Tribunal Constitucional, ya en su primera Sentencia de 2 de Febrero de 1981.

23) Parafraseando a Ramón MARTIN MATEO, las máximas posibilidades de autonomía de un grupo social radican en la libre e integral adopción de su propia organización. "La autonomía local y el sistema normativo español", en R.A.P., nº. 94, 1981.

24) Tal y como acertadamente sostiene Antonio EMBID IRUJO, al referirse a la pretensión de darse una Carta municipal. "Autonomía municipal......", en R.E.D.A., 1981, no. 30, pág. 462.

25) Ramón MARTIN MATEO, "La autonomía local...", loc. cit., pág. 63.

26) Luciano PAREJO ALFONSO, Drecho básico de la Administración Local, Ariel, Barcelona, 1988.

27) Ambito local reconocido por la propia Sentencia 214/1989, en su Fundamento Jurídico Sexto.

28) No obstante, la posible utilización del recurso de amparo para la garantía de las autonomías locales fue ya apuntado por Ramón MARTIN MATEO, "La garantía constitucional...", loc. cit., pág. 604. También pueden citarse: José Ignacio LOPEZ GONZALEZ, "Legitimación de las Corporaciones locales para recurrir en amparo", en R.E.D.A., 1983, no. 38, pág. 429; Lorenzo MARTIN RETORTILLO, "Las Corporaciones locales y el recurso constitucional de amparo", en 
vol. col. Organización Territorial del Estado (Administración Local), Vo. III, IEF, Madrid, 1985, págs. 1983 y sigs.; Luis ORTEGA, El régimen constitucional de las competencias locales, INAP, Madrid, 1988, págs. 24 y sigs.

29) Una síntesis puede verse en Miguel SANCHEZ MORON, "La defensa jurisdiccional de la autonomía local", en vol. col. Comunidades Autónomas y Gobiernos Locales, Diputación de Barcelona, 1987, págs. 319 a 322. 


\section{LAS GARANTIAS PERSONALES EN DERECHO ROMANO JUSTINIANEO}

VICTORIANO SAIZ LOPEZ

\section{1.- Planteamiento general.}

En el estudio de la evolución de las garantías personales en el derecho romano justinianeo, las conclusiones a que ha llegado ASTUTI, en torno a la relación existente entre stipulatio y constitutum debiti alieni, basadas en la constitución reformadora $\mathrm{CJ} 4,18,2$, son, a nuestro juicio, especialmente relevantes a la hora de plantear el problema de los criterios seguidos por los compiladores.

Con posterioridad, los estudios de autores como FREZZA y particularmente ARCHI, sobre el discutible alcance práctico de la revisión bizantina de las antiguas fuentes romanas, han venido a enriquecer una polémica doctrinal que se inserta en otra más amplia referida a los criterios que presidieron la elaboración del Corpus Iuris.

Recientemente, el Profesor DIAZ BAUTISTA ha puesto de actualidad nuestro tema con su trabajo sobre las instituciones de garantía bancaria en la legislación de Justiniano.

La aportación que pretendemos hacer aquí consiste fundamentalmente en una síntesis de las diversas posiciones doctrinales y en el desarrollo de una interpretación de CJ 4, 18, 2 que plantea cuál ha podido ser el destino final de las instituciones romanas en la vida efectiva del Derecho en la parte oriental del Imperio.

La constitución de Justiniano del año 531 nos presenta la abolición del receptum argentariorum, que ha caído en desuso, en relación con el constitutum debiti (1).

Recepticia actione cessante quae sollemnibus verbis composita inusitato recessit vestigio, necessarium nobis visum est magis pecuniae constitutae naturam ampliare (C. $4,18,2$ ).

Después de ampliar el ámbito de aplicación de la a. pec. const., Justiniano insiste en el principio de que el constitutum debe tener una deuda como presupuesto objetivo para su validez, justificando la abolición de la recepticia, precisamente, por lo absurdo e inicuo de la abstracción que caracterizaría a este instituto.

...ita tamen, ut hoc ei inhaereat, ut pro debito fiat constitutum (cum secundum antiquam recepticiam actionem exigebatur et si quid non fuerat debitum), cum satis absurdum et tam nostris temporibus quam iustis legibus contrarium est permittere per actionem recepticiam res indebitas consequi...

En las Instituciones encontramos una explicación de la reforma en términos muy parecidos. (I. 4, 6, 8). 
...de pecunia constituta, cui similis videbatur recepticia: sed ex nostra consititutione (cum et, si quid plenius habebat, hoc in pecuniam constitutam transfusum est) et ea, quasi supervacua, iussa est cum sua auctoritate a nostris legibus recedere (2).

Según sabemos, como consecuencia de esta abolición, los compiladores omitieron en el Digesto un título correspondiente a la cláusula del Edicto del Pretor relativa al receptum argentariorum, borrando toda huella de este instituto en la compilación, insertando bajo la rúbrica de pec. const. y en otras partes, con las debidas modificaciones, algunos textos clásicos que originariamente se referían al receptum.

En general, se ha interpretado lo anterior como una fusión de ambas instituciones y como una ampliación del constitutum en relación con la abolición del receptum (3).

Igualmente, de acuerdo con los datos que Justiniano suministra, se ha llegado a admitir una gran afinidad entre las dos instituciones (4).

En esta dirección, aunque admitamos que función económica del receptum es la de una apertura de crédito, ya que opera con independencia de que el cliente tenga $o$ no fondos depositados en poder del banquero, también podemos considerar como muy probable que el banquero, asumiendo la deuda de otra persona, normalmente, tendrá en su poder fondos depositados por ésta; por tanto, el banquero es deudor del cliente respecto de estas cantidades. De este modo, el receptum puede ser equiparado no sólo al c. d. alieni, como se viene considerando en general, teniendo en cuenta, exclusivamente, la relación jurídica entre el cliente y el tercer acreedor, sino que también el receptum puede ser equiparado al mismo c. debiti proprii. Esto es así, si nos fijamos en la relación jurídica existente entre el banquero depositario y su cliente.

Esta doble función económica que cumple el receptum se concreta del siguiente modo:

1.- Aceptación ex recepto ordinaria, por parte del banquero, de la responsabilidad derivada de una deuda de su cliente. En este caso estamos ante una apertura de crédito.

2.- Aceptación ex recepto, por parte del banquero depositario de fondos del cliente, de la responsabilidad derivada de una deuda del mismo, con lo que el banquero ejecuta pagos a cuenta del cliente, cumpliendo su obligación de restituir propia de un depositario. Aquí, el banquero actúa como administrador de un patrimonio ajeno y cumple la función de intermediario en los pagos, facilitándolos al evitar los inconvenientes del intercambio material de numerario. $Y$, lo que es muy importante, puede contribuir a incrementar los medios de pago en función del desarrollo económico, mediante la concesión del crédito.

La bipolaridad a que nos acabamos de referir puede estar en paralelo con la función y desarrollo histórico del constitutum, lo que podría explicar el destino final convergente de ambas instituciones (5).

También se considera la existencia de una contradicción en relación con los motivos que alega Justiniano en materia de abolición del receptum. Así, se habla, 
en primer lugar, de la caída en desuso del receptum, es decir, de la acción antigua de la que se borra toda huella del Digesto (6); pero resulta soprendente que la no utilización del receptum pueda servir de justificación de la necesidad de ampliar el constitutum, siendo inadmisible un absurdo intento de perpetuar o, mejor dicho, de hacer revivir las reglas características de una institución abandonada en la práctica. Además, lo que venimos diciendo contrasta con lo que dispone nuestra constitución, en estos términos:

His videlicet, quae argenti distractores et alii negotiatores indefense constituerint, in sua firmitate secundum morem usque adhuc obtinentem durantibus.

Se ha venido entendiendo que aquí estaríamos ante una disposición transitoria, una cláusula de derecho intertemporal aplicable a los recepta concluidos por los banqueros con anterioridad a la entrada en vigor de la reforma (7). Pero, esta interpretación choca frontalmente con el dato relativo a la caída en desuso del receptum. No es necesaria una norma transitoria para un negocio que no vincula a los banqueros (8).

En esta dirección, considerando la hipótesis según la cual el receptum argentariorum habría tenido su continuación en la promissio de los banqueros en el derecho comercial medieval (9), se llega a mantener que el receptum ha permanecido en Occidente, y especialmente en Italia, mientras que en Oriente la no recepción del instituto habría sido la causa verdadera de la constitución reformadora de Justiniano. El motivo de esta no recepción se encontraría en el hecho de que el receptum tenía un correspondiente en su función económica y en su estructura jurídica en el derecho griego. En Oriente no se habría practicado el receptum, tal y como era conocido por los romanos, al existir alli un instituto propio que cubre las mismas necesidades. Así, la reforma justinianea se habría limitado a recoger la persistencia de esta tradición jurídica helenística. Los compiladores encuentran el receptum en los escritos de los clásicos pero no en la práctica de su tiempo y, no conociendo su historia ni el derecho en Occidente, habrian caído en un comprensible error, creyendo de buena fe que el instituto estaba en desuso. La pretendida disposición transitoria vendría referida no al receptum sino al constitutum debiti (10).

Sin embargo, la hipótesis anterior suscita más de una razón de duda. Por lo que se refiere a la persistencia del receptum argentariorum en las regiones occidentales del Imperio, podemos decir que constituye una premisa que está todavía por demostrar, pues se basa en fundamentos muy inciertos. En cuanto a la adhesión a la hipótesis de la no recepción en Oriente, sin duda, es cierto que el mundo de los negocios de los "argentarios" romanos estaba organizado a imitación del mundo de los "trapezitas" griegos. Se puede hablar de asimilación de los institutos y de los esquemas negociales, entre los que hay que incluir el receptum. En efecto, puede parecer probable la no recepción de un instituto que el derecho romano había tomado prestado del derecho griego. Es inverosímil que la expansión imperial de Roma haya podido ofrecer a la práctica de las regiones de Oriente algo nuevo e influir en el desarrollo de un tráfico bancario muy evolucionado que habia llegado a generalizarse en todo el mundo antiguo. 
Ahora bien, entendemos que el receptum viene enmarcado dentro de la órbita jurídica del derecho romano y obedece a unas necesidades históricas muy concretas $\mathrm{y}$, aunque pretenda acoger los principios del modelo griego, no por ello puede desconocerse la originalidad de la institución. En definitiva, hemos de reconocer que en este campo no se halla plenamente desvelada la incertidumbre en lo referente a la afinidad jurídica entre las figuras negociales del tráfico bancario griego y el receptum argentariorum (11).

Aun cuando no aceptemos la hipótesis de la no recepción, lo que parece indudable es que nuestro instituto es desconocido y no utilizado en la práctica justinianea. Puede haber dudas en cuanto a los motivos, pero no en relación al hecho mismo de que la acción recepticia pertenece al pasado.

En efecto, partimos de que el receptum argentariorum es desconocido en la práctica de la época de Justiniano (12). No se podría objetar que mal se entiende la abolición legislativa de una institución condenada inapelablemente al olvido, puesto que, es comprensible que Justiniano, al encontrarse ante una reliquia de la jurisprudencia clásica en los comentarios ad edictum, considerase oportuna una expresa derogación de aquellas normas, lo que, ocasionalmente, llevó a cabo en la misma constitución en que reformaba el constitutum.

A esta conclusión parece oponerse la disposición ya conocida que, según la opinión común, constituiría una disposición transitoria relativa al receptum. Pero, si esta opinión común es cierta habría que atribuir a Justiniano no sólo una falsa noticia sino también una inadmisible contradicción. Puede dudarse de ciertas afirmaciones de los bizantinos, pero con mayor cautela deben acogerse otro tipo de noticias que no pueden ser rechazadas sin graves motivos, como ocurre con ésta. Cuando Justiniano se refiere al desuso del receptum, nada impone al emperador afirmar una cosa falsa, lo que todos habrían podido constatar. Tampoco sería admisible declarar insusitado un negocio y, al mismo tiempo, emanar una norma transitoria apelando al mos usque adhuc obtinens. Pero hay más; en esta disposición se usa la expresión indefense constituere, cuando no hay razón para no recurrir al término técnico recipere, como en los parágrafos precedentes, máxime si tenemos en cuenta que se refiere a los argenti distractores et alii negotiatores, siendo el receptum el negocio propio de los argentarii. Resulta también extraño que donde el emperador debía haber confirmado la validez de los recepta, concluidos con anterioridad a la reforma, haga referencia al mos usque adhuc obtinens.

Es posible que, con estas palabras, Justiniano no se haya referido al receptum. Tampoco se referiría al normal constitutum pro alio sino a las promesas con las que, según sus usos, banqueros y mercaderes se obligaban a pagar indefense. Promesas que pueden reconducirse al concepto general de constituere de mayor amplitud que el constituere clásico. Que en la práctica del mundo bancario helenístico se encontrasen en uso formas de garantía diversas del constitutum romano, que no podamos identificar entre ellas al receptum argentariorum, aunque a éste puedan parecer afines, y que su régimen jurídico venga referido en las fuentes justinianeas al constitutum debidamente transformado, bajo el nombre genérico de "antiphonesis", aparece, seguramente confirmado, para el período imnediatamente sucesi- 
vo al 531, por otras fuentes, entre las que podemos citar la Nov. IV, Nov. CXVI c. 6, Nov. CXXXVI, Ed. VII y Ed. IX de Justiniano (13).

En virtud de los textos posteriores a la reforma del 531, el constitutum -antiphonesis- de los argentarii vendría, ordinariamente, asumido sin las limitaciones de la responsabilidad del promitente pro alio que propias del derecho común. Para probar que esto es así, recurrimos a los dos pricipios siguientes:

1.- El referente al beneficium excussionis.

2.- El carácter riguroso de la obligación bancaria, con arreglo a la terminología indefense constituere.

El primer tema que se nos plantea es el de determinar al alcance del beneficium excussionis. En la novela CXXXVI, Justiniano modifica lo dispuesto en la Novela IV en la cual declaraba (cap. 3, p.1) no ser admitidos los banqueros al beneficium ordinis seu excussionis, ahora introducido. La corporación de los baqueros habría presentado una protesta, seguramente por medio del comes sacrarum largitionum strategius, al que el emperador dirige en contestación la Novela CXXXVI. Los banqueros, con esta Novela, son admitidos a pactar, en su favor, la renuncia al beneficio de excusión cuando hayan dado dinero a título de mutuo, recibiendo garantes del mutuatario. De este modo, Justiniano da acogida a una de las dos alternativas contenidas en la protesta de la corporación bancaria: o la extensión a los contratos en que los banqueros son deudores (garantes) del beneficio de la Novela IV (benef. ordinis seu excussionis), o la exclusión de los contratos en que los banqueros son acreedores (y han recibido garantes) del beneficio de la Novela IV (14).

En el segundo punto, consideramos la costumbre de los banqueros de renunciar, convencionalmente, a las ventajas del derecho común en la garantía de la obligaciones; parece seguro que, después de haber condenado en C. 4, 18, 2 la recepción de obligaciones abstractas y de haber remachado el principio según el cual el constitutum debe tener siempre como presupuesto una deuda, Justiniano considera oportuno excluir la aplicación de estos principios a la conocida antiphonesis que los banqueros y comerciantes hayan contraído indefense, respetando, al menos en vía transitoria, los usos comerciales de su tiempo (15).

Esta interpretación concuerda con el sentido del término indefense constituere, sobre el que tanto se ha escrito desde los glosadores (16).

Tradicionalmente, se viene entendiendo que el término serviría para indicar ut nulla exceptione se tueri possint, sine ulla defensione, vel exceptione (17).

Considerando lo anteriormente establecido, el indefense constituere puede ser, solamente, la fórmula que contiene la situación jurídica de quien ha asumido un vínculo obligatorio de carácter abstracto que debe cumplir sin poder oponer excepciones (18).

En defintiva, que el receptum argentariorum es para Justiniano un instituto del pasado y mal conocido, aparece claro si se tienen en cuenta las fórmulas vagas y equívocas con que viene caracterizado: por ejemplo, las palabras sollemnibus verbis composita, sobre las que tanto se ha discutido, plantean el problema relativo a si califican al negocio, a la acción o al libelo. Es difícil buscar una solución satisfacto- 
ria a este interrogante; probablemente, con esta expresión se ha querido apoyar la afirmación del desuso del instituto, recurriendo a su hipotético formalismo. A atribuir carácter formal al receptum también pudo contribuir la presencia de un término puramente romano como recipio, que los bizantinos encontraban en las fuentes junto a spondeo, dico y que debían considerar igualmente arcaico y quiritario (19).

Lo que aparece bien claro en la constitución del 531, por lo que se refiere al receptum, es la decidida condena de su carácter abstracto en la que se funda la retórica declaración sobre lo absurdo e incompatible del instituto con las leyes y la consiguiente orden de cancelar en la compilación toda referencia a la antigua acción recepticia.

Si todo esto es cierto y se el receptum argentariorum no puede considerarse un instituto vivo en el tráfico jurídico de la época de Justiniano, se impone la necesidad de clarificar la relación existente entre la abolición del receptum y la ampliación del constitutum.

Comencemos poniendo en duda la pretendida transferencia de elementos del receptum al constitutum (20) y la influencia que ha podido ejercer el primero en la reforma del segundo (21).

Si nos planteamos, en este sentido, cuál es la razón por la que Justiniano reformó el constitutum debiti, no parece acertado hallarla ni en el hecho de que el receptum había desaparecido, ni en la necesidad de extender el constitutum a cuanto de plenius tenía el receptum (22).

El punto de partida para una adecuada interpretación de la reforma es reconocer el importante papel que el constitutum asume en las fuentes posteriores a la constitución reformadora. En ellas, el constitutum debiti alieni adquiere una posición de neta prevalencia; bajo el término griego antiphonesis encontramos regulado el negocio de garantía y el de recepción de deuda practicado por los banqueros bizantinos, los cuales recurrían, con toda probabilidad, a formas contractuales propias de su tradición jurídica (23).

Ahora bien, la transformación del constitutum no resulta de la constitución reformadora con la que, precisamente, esta transformación se debería haber producido. Las innovaciones introducidas con ella por Justiniano que, en hipótesis, deberían considerarse derivadas del receptum, no son eficaces para tal fin. En efecto, en ese largo texto, si bien son significativas las referencias al receptum como promesa pro alio, sin embargo, no se da particular relieve todavía al constitutum como forma de recepción de deudas ajenas en el campo de las garantías personales. Sobre la posibilidad de prometer pro alio se hace una fugaz referencia, incidentalmente, al tratar de la perpetuidad de la acción (24).

Pero hay más; las muy discutidas innovaciones que se deberían haber producido a imitación del receptum, es decir, los elementos que de éste deberían haber sido transferidos al constitutum, se reducen en realidad a bien poco y, precisamente, consisten sólo en la extensión objetiva de su ámbito de aplicación más allá del límite clásico de las deudas referidas a res quae in pondere numero mensura consistunt. Es, ciertamente, sorprendente que a este hecho no se le haya dado la debida 
importancia y que, por consiguiente, no se hayan extraído las debidas consecuencias que permite el examen del contenido normativo de nuestra constitución (25).

$\mathrm{La}$ afirmación que acabamos de hacer encuentra su fundamento en las siguientes razones:

1.- La plena transmisibilidad hereditaria activa y pasiva de la a. pec. const., así como la aplicación de la regla praescriptio triginta annorum, aparecen como consecuencias naturales del desarrollo histórico del negocio y de la desaparición de su originaria naturaleza penal de la que dependían las limitaciones precedentes; por ello, no pueden ser reconducidas al receptum y, para el c. deb. alieni., Gordiano había reconocido la perpetuidad y transmisibilidad hereditaria pasiva de la acción (26).

2-. Por otra parte, el reconocimiento de la validez del constitutum debiti in diem y sub condicione se debe, simplemente, al cambio de concepción de la estructura de las relaciones jurídicas condicionadas, es decir, a la admisión de la eficacia retroactiva a la verificación de condición, equiparada en este aspecto al dies en la época postclásica (27). Y, además, es decisión legislativa de cuestiones discutidas por la jurisprudencia clásica en tema de constitutum.

3.- Incluso, por lo que se refiere a la extensión del constitutum más allá de las deudas pecuniarias, es legítima la duda de que ello puede derivar del receptum argentariorum. La norma viene concebida en términos generales, admitiendo la posibilidad de garantizar por constitutum, non solum res quae pondere numero mensura sunt, sed etiam alias ommes sive mobiles sive immobiles sive semoventes sive instrumenta vel alias quascumque res, quas in stipulationem possunt homines deducere (28). Una confirmación de esto la tenemos en el Digesto, donde viene reconocida, mediante interpolación, la posibilidad de constituirse lo debido ex quocumque contractu sive certi sive incerti (29). Como vemos, ahora se habla tanto de obligaciones ciertas como de obligaciones inciertas; pero lo que resulta claro es que del constitutum de obligación incierta no tenemos ejemplo alguno. Ello nos lleva a considerar que la genérica extensión no debe tener gran importancia práctica. Y, como hemos visto, el mismo Justiniano hace referencia sólo a la hipótesis de obligación cierta.

Aun reconociendo la validez de las conclusiones anteriores, nos interesa todavía insistir en este punto concreto. Resulta muy significativo que los compiladores introdujesen en el título del Digesto dedicado al constitutum fragmentos que, originariamente, estaban referidos a receptum, como ha demostrado la crítica interpolacionista. Resulta muy significativo, porque nos hace concebir la idea de que el constitutum se nutre a consta de la desaparición del receptum argentariorum. Si nos fijamos bien, el constitutum es un negocio jurídico con un ámbito personal de aplicación generalizado, mientras que esto no resulta válido para el receptum. Nos preguntamos cuál sería entonces el modo en que opera la reforma. Creemos que se trata de engrosar, de manera artificial, el constitutum que va a acoger en su seno una institución de derecho bancario caracterizada por un régimen jurídico muy distinto del que es propio del negocio ahora ampliado. nos encontramos ante un ejemplar con dos naturalezas, ya que no hay unificación jurídica y ssólo se puede hablar de 
cambio semántico cuyo alcance parece ser más teórico que práctico. En efecto, en el Digesto se regula el constitutum como institución de derecho común y aquí ya no se hace referencia alguna a su nueva vertiente especial de derecho bancario que habría introducido la constitución del 531, mientras que el régimen de la contratación de los argentarii se desarrolla por la vía independiente de las Novelas, bajo el término de antiphonesis pura. Por otra parte, la moderna traducción del antiphonesis, en sentido general, por constitutum resulta muy descutible y sólo tiene en su apoyo los datos que suministra la constitución reformadora del 531, como ya iremos viendo. Estamos, por tanto, ante un problema terminológico que no puede ocultar las diferencias, en cuanto al régimen jurídico, entre estas instituciones, la de D. 13, 5 y la recogida en las Novelas. Pero, volviendo a la constitución reformadora, hay que saber cuál puede ser el motivo por el que constitutum y acción recepticia aparecen unidos. Sin duda, resultaba necesario encuadrar la garantía bancaria helenística dentro de alguna de las categorías ya conocidas por el Derecho romano, y para ello no se encuentra otra cosa mejor que aprovecharse de la evolución que, por su parte, estaba sufriendo el constitutum, en el sentido de ampliar su ámbito de vigencia (30).

La función de garantía que el constitutum había podido cumplir, con los mismos caracteres, en el derecho clásico, aparece ahora acentuada, sobre todo, en las fuentes justinianeas y bizantinas posteriores a la reforma del 531. Esto se explica al prevalecer en la práctica jurídica el constitutum debiti alieni respecto al constitutum debiti proprii que todavía en el Digesto aparece considerado como la forma principal, pero cuya función en el derecho clásico viene a menos en el derecho justinianeo.

En el párrafo anterior, por decirlo gráficamente, se está considerando el viejo tranco del constitutum romano injertado en la nueva savia de la antiphonesis helenística de las Novelas. Esta imagen es una consecuencia del planteamiento que, ante todo, busca establecer un parelelismo entre las instituciones del Derecho romano y las de Derecho helenístico. Planteamiento al que, sin pretender negar su interés, no podemos olvidar que, de una parte, la tradición griega viva de las Novelas y, de otra, el anquilosado constitutum del Digesto no coinciden plenamente. Las diferencias entre ellos no derivan sólo de la evolución histórica sino que son el producto del contraste de dos diversos ordenamientos jurídicos, con estructuras y principios propios. Otra cosa son los problemas planteados por la necesidad de traducir del griego al latín, y aquí sí resulta posible colocar el término constitutum por el de antiphonesis después del 531. Pero ni ésta es la única posibilidad, ni quizá sea la mejor.

En estas circunstancias, nos parece oportuno asignar al término constitutum una doble acepción, dentro del ámbito del Derecho helenístico.

1.- Como vestimenta romana de un negocio perteneciente a la tradición jurídica griega (31).

2.- Como negocio perteneciente al derecho bizantino en materia de garantía personal de las obligaciones. 
El mismo doble significado anterior podemos atribuir al discutido indefense constituere.

Las consideraciones anteriores nos permiten llegar a una interpretación sobre el significado real de la reforma del 531.

En primer lugar, vamos a recordar el contenido normativo del texto de Justiniano (C. 4, 18, 2), subrayando los términos que en este momento nos interesan especialmente:

...hac apertissima lege definimus ut liceat omnibus constituere non solum res quae pondere numero mensura sunt, sed etiam alias omnes sive mobiles sive immobiles sive semoventes, sive instrumenta vel alias quascumque res, quas in stipulationem possunt homines deducere, et neque sit in quocumque casu annalis, sed (sive pro se quis constituat sive pro alio) sit et ipsa in tali vitae mensura, in qua omnes personales sunt actiones, id est in annorum metis triginta: et liceat pro debito puro vel in diem vel condicionali constitui: et non absimilem penitus stipulationi habeat dignitatem, suis tamen naturalibus privilegiis minime defraudata: sed et heredibus et contra heredes competat, ut neque recepticiae actionis neque alio indigeat res publica in huiusmodi casibus adminiculo, sed sit pecuniae constitutae actio per nostram constitutionem sibi in omnia sufficiens... hoc tantummodo constituatur, quod debitum est, et omnia, quae de recepticia in diversis libris legislatorum posita sunt, aboleantur et sit pecunia constituta omnes casus complectens, qui et per stipulationem possint explicari.

El fin peseguido por nuestra constitución es la extensión del ámbito de aplicación de la actio pecuniae constitutae. En efecto, en la compilación resulta alterada la típica función que el edicto de pecunia constituta había cumplido en el sistema clásico. Los bizantinos nos presentan una acción reipersecutoria y el constitutum debiti como una promesa de pago, es decir, como una figura contractual cuyo objeto es el cumplimiento de una prestación ya debida por una causa precedente y paralela a la stipulatio debiti.

Resulta significativa la insistencia con que en la constitución del 531 se hace referencia a la stipulatio, lo que nos confirma que es en ésta, precisamente, y no en el receptum (32), en la que el emperador está pensando al suprimir las antiguas limitaciones del constitutum. Lo que se persigue es la plena equiparación de esta figura pretoria con la general forma contractual civil (33).

Probablemente, esta equiparación con la stipulatio se enmarca dentro del proceso de evolución degenerativa de la obligatio verborum, en el que decae su típico requisito formal de la oralidad. $\mathrm{Y}$, por lo que se refiere al requisito de la presencia de las partes, como es sabido, venía siendo posible un simple reconocimiento, ordinariamente escrito, de haber realizado el acto, admitiéndose la prueba en contrario dentro de muy restringidos límites (34). En el sistema del derecho justinianeo, en el que el carácter formal de la estipulación se reduce sustancialmente al animus stipulandi y, al mismo tiempo, vienen atenuados los efectos rigurosos de su carácter abstracto, respecto a la causa praecedens, el paralelismo aparece tan acusado que hace muy difícil discernir cuándo estamos ante una stipulatio y cuándo ante un constitutum (35). 
En suma, el reconocimiento de la posibilidad de asumir por constitutum todo tipo de prestaciones no derivaría de su pretendida fusión con el receptum, sino que encontraría su apoyo en la interpolación del texto del Digesto 13, 5, 1, 6, en el que viene proclamada la general aplicación del instituto para cualquier débito, ex quacumque causa - id est ex quocumque contractu sive certi sive incerti (36).

\section{2.- Alcance práctico de la reforma.}

La principal nota característica de la evolución de la garantía personal en el derecho postclásico y justinianeo puede expresarse mediante el término simplificación (37).

En lugar de aquella multiplicidad de instituciones propia del derecho clásico (38), subsiste ahora, únicamente, la fideiussio (39). Se considera esta fideiussio, de época tardía, dilatada hasta cubrir casi el concepto de garantía personal. Por el contrario, la fideiussio, en el sentido restringido de los clásicos, corresponde a una concepción de la garantía en una sociedad que tiene gran necesidad del crédito y que por ello ha dado gran impulso a la elaboración del correspondiente concepto jurídico. Esta idea está presente en el pensamiento de los juristas clásicos que elaboran los principios que han de llevar de la antigua sponsio a la accesoriedad, concorde con la nueva fideiussio. Aunque muchas normas sean comunes a los tres tipos de garantía, también es cierto que sponsio y fidepromissio se revelan arcaicas en su estructura (40).

La exposición de este sistema clásico, que debe tener en cuenta una multiplicidad de posibilidades, ha de resultar complicada. Ahora bien, cuando, posteriormente, las normas propias de la fideiussio comienzan a prevalecer en las mismas fuentes clásicas, llegadas a nosotros a través de la manipulaciones de la práctica y de las escuelas de Occidente y Oriente, tenemos una simplificación del cuadro y, en consecuencia, queda aligerada la labor del reconstructor.

En efecto, la posición preponderante que llega a asumir la fideiussio, en el ámbito de la garantía personal, es el fruto de una evolución que va incluso más allá del periodo considerado como propio del Derecho romano. Por el contrario, la concepción clásica da al problema de la garantía del crédito amplios confines y una gran riqueza de soluciones. De aquí deriva la variedad de institutos que en el derecho clásico operan en este campo: en un mundo económico en el que la labor de los juristas da impulso a la circulación del crédito, fideiussio, fideiussio indemnitatis, mandato de crédito, constitutum debiti, receptum argentariorum y otros institutos relacionados con la garantía forman un amplio abanico que se abre ante nuestros ojos.

La desaparición de esta rica articulación no sería más que el reflejo, sobre el terreno jurídico, de la crisis de la estructura social y del sistema económico. Por ello, el término simplificación no resulta totalmente exacto. En efecto, no se trata de eliminar lo que en el sistema clásico podía ser considerado como sobrante o incluso arcaico; más bien, podemos decir que en la evolución del Derecho romano, a partir del siglo IV, dichos institutos están presentes en la literatura jurídica, pero no encuentran más que modesta respuesta y mal entendimiento en la práctica (41). 
Si lo anterior es cierto, consideramos que, en esta materia de reforma de las garantías personales, no sería la práctica la que habría movido al legislador; la intervención de éste habría venido solicitada por exigencias sistemáticas, manifestadas en el curso de las labores de compilación, en la revisión de las antiguas fuentes de las que se quería conservar lo más posible, compatibilizándolo con la inteligencia y la comprensión de las nuevas generaciones (42).

Vamos a intentar poner de manifiesto, en las próximas líneas, cómo es, sobre todo, sistemático y escolástico más que práctico el resultado de la reforma. Pero también esta nueva visión teórica no surge, exclusivamente, de la simple reflexión, pues está pensada para cubrir las necesidades planteadas por la evolución del derecho helenístico a través de las Novelas (43).

Para concretar esas ideas, en el tema de la valoración de la reforma del 531, es preciso que llevemos a cabo el análisis de la misma desde las siguientes cuestiones:

1.- ¿Es posible un constitutum referido a deuda condicionada?.

2.- ¿Cuál es el tiempo de prescripción de la a. pec. const.?.

3.- ¿Es transmisible la a. pec. const. a los herederos y contra los herederos?.

4.- ¿Es posible un constitutum referido a deuda inexistente?

5.- $¿$ Es posible un constitutum referido a deuda en cuyo objeto figuren cosas distintas de las que in pondere numero mensura sunt?.

Antes de entrar en cada una de estas cuestiones, hay que tener en cuenta que la constitución va dirigida a considerar los caracteres de la actio pecuaniae constitutae. Afronta los problemas no desde un punto de vista sustantivo sino procesal. En otras palabras, tiene un estilo conforme a los esquemas que, en la época de Justiniano, debían ser conocidos sólo por quienes estaban familiarizados con los iura. Esta primera observación nos hace pensar más en un interes escolástico que verdaderamente práctico de nuestra constitución.

Comencemos por el número que trata de la posibilidad de constituir un débito bajo condición: ...et dubitaretur, si pro debito sub condicione vel in diem constituto pecunia contracta valeret. Que en el derecho clásico se admite, sin discusión, la posibilidad de constituere debitos in diem, viene probado por D. 13, 5, 3, 2 y por D. $13,5,4$ (44). Por ello no se alcanza a comprender la dubitatio a que se refiere el texto imperial. De otro modo se presentan las cosas en tema de relaciones obligartorias condicionadas, para las cuales la noticia de discusiones encuentra credibilidad por la agitada historia que este tipo de relación ha tenido en Derecho romano. También sabemos que la cláusula condicional sufre un profunda alteración en el periodo postclásico (45). Ahora bien, si nos referimos a la fórmula clásica de la actio pecuniae constitutae, se presenta como legítima la duda de poder constituere un débito condicional. Pero esto ya no es así si se piensa en los princinpios postclásicos, con arreglo a los que la condicio se ha convertido en una cláusula extrínseca del negocio, siendo equiparada a estos efectos al dies. La duda, por consiguiente, no puede venir de estos ambientes que reflejan el derecho romano tardío. Parece que está muy próximo a la verdad el pensar que esta duda vendría planteada 
en centros en que objeto de estudio eran las obras de los clásicos, especialemente de los útimos clásicos, entre los cuales la construcción del negocio condicionado había alcanzado la suficiente madurez para justificar un reexamen del problema de constituere una relación sub condicione (46).

La cuestión planteda en el número 2 viene expresada en el texto imperial en los siguientes términos: neque in omnibus casibus longaeva sit constituta (actio), sed in speciebus certis annali spatio concluderetur. La solución dada por Justiniano es la siguiente: et neque sit in quocumque casu annalis, sed (sive pro se quis constituat sive pro alio) sit et ipsa in tali vitae mensura, en qua omnes personales sunt actiones, id est in annorum metis triginta...

Para una recta valoración de esta frase, conviene recordar algunos principios de la actio pecuniae constitutae del período formulario. Esta, según la opinión hoy prevalente (47), tiene naturaleza penal, al menos originariamente, y es anual. Es acertado, según los textos clásicos, que el desarrollo histórico del instituto y, en particular, la posibilidad de una constitutum debiti alieni han acentuado la función reipersecutoria de la actio que, precisamente por esto, en tales casos, ha dejado de tener naturaleza penal (48). Fundamental para este punto es D. 13, 5, 18, 2.

Función penal o reipersecutoria de la acción; anualidad o el tiempo propio de la prescripción de la acción son temas conocidos y, diremos, queridos por la última jurisprudencia clásica. Para ésta, el desarrollo de la cognitio extra ordinem, en el ámbito penal y en el civil, agravó ciertos poblemas al no coincidir en muchos puntos con el proceso formulario. En efecto, si hay una esfera del Derecho para la que el paso a la época constantiniana ha señalado una decisiva diferencia en relación al periodo precedente, ésta es la de la prescripción de la acción (49).

La prescripción teodosiana, y sus desarrollos, ha acentuado este movimiento de diferenciación, ofreciendo a la práctica nuevos problemas. Y, como sabemos, de la anualidad de la acción pretoria se pierde toda huella en las fuentes postclásicas (50).

Las premisas que hemos establecido son importantes para expresar un juicio sobre lo que C. 4, 18, 2 nos transmite, en las frases citadas, sobre el punto 3; aquí se puede concluir como en el precedente. Nos encontramos frente a una cuestión que tiene mayor probabilidad de reflejar disputas antiguas perpetuadas por nuevos exégetas que dudas debidas a cuestiones actuales. Para confirmar esta conclusión debemos fijarnos en el inciso puesto entre paréntesis; del mismo puede deducirse que la prescripción varía según se trate del c. debiti proprii o debiti alieni; según se ha mantenido, El caso del constitutum debiti alieni sería un supuesto en el que la acción perdía sus caracteres originales de penalidad y anualidad.

La cuestión recogida en el número 4 ha dado lugar a una interpretación según la cual Justiniano rechaza la tesis de quien trataba de atribuir al constitutum, sobre el ejemplo del receptum recogido a este propósito, la naturaleza de negocio abstracto.

Si lo anterior es cierto, esta decisión imperial entraría en la lucha mantenida por Justiniano contra la teoría del negocio abstracto (51). Ello viene recogido en los siguientes términos: cum satis absurdum et tam nostris temporibus quam iustis legibus contrarium est permittere per actionem recepticiam res indebitas con- 
sequi et iterum multas proponere condictiones, quae et pecunias indebitas et promissiones corrumpi et restitui definiunt.

La frase es significativa; quien aquí escribe conoce bien el fragmentarse de la unitaria condictio clásica en una multiplicidad de condictiones. Conoce incluso la figura de la condictio liberationis. Si leemos esta frase a la luz de cuanto la compilación testimonia en tema de multae condictiones y de condictio liberationis, parece justificado ligar la polémica de la cancillería imperial con las divergencias entre los maestros bizantinos que comentaban los textos clásicos. Además, el juego conjunto del aspecto sustantivo y procesal, por el que quien ha emitido la declaración de pagar, debe hacerlo, porque es verdadero deudor, aunque después pueda condicere esto que ha pagado, corresponde a una sistemática jurídica conforme a las concepciones romano-clásicas.

Finalmente, en el número 5 tenemos la extensión del constitutum más allá de las deudas en cuyo objeto figuran las res quae in pondere numero mensura sunt. Justiniano, después de haber proclamado que la razón de su innovación extensiva es la convertibilidad en dinero de todas las cosas, defiende la nueva norma invocando lo que se puede leer in libris iuris auctorum et in alia antiqua prudentia. El silencio sobre la nueva función asumida, ya antes de Justiniano, por el constitutum, al prevalecer la aplicación del c. debiti alieni, es un significativo testimonio de que las controversias de C. $4,18,2$ pertenecen a ambientes que estudian el Derecho más sobre la autoridad del pasdo que sobre la realidad del presente.

De los apartados anteriores podemos deducir que C. 4, 18, 2 no va encuadrada, propiamente, en el desarrollo que el constitutum debiti puede haber tenido en la vida efectiva del Derecho de la parte oriental del imperio; propone cuestiones que encuentran su encaje en los últimos desarrollos clásicos, pero que seguían vivos en la época de Justiniano, únicamente, en discusiones en las escuelas jurídicas. En efecto, el que C. $4,18,2$ pertenezca al grupo de las que Justiniano define (52) ad commodum propositi operis pertinentes nos advierte de que nos encontramos frente a una constitución dirigida a enmendar el ius antiquum.

Pero, además, aun reconociendo la validez de estas conclusiones, no podemos dejar de considerar el parágrafo 2 de nuestra constitución. En el mismo encontramos, como es sabido, una referencia explícita a propósito de los banqueros y, en general, de los negotiatores, mencionándose el constitutum hecho indefense en los siguientes términos: His videlicet, quae argenti distractores, et alii negotiatores, indefense constituerint, in sua firmitate secundum morem usque adhuc obtienentem durantibus.

Esta disposición abre la puerta a la evolución del derecho bancario helenístico, con posterioridad a la reforma, a través de la legislación introducida por las Novelas.

Nos interesa ahora entrar en el estudio del desarrollo histórico, en el mundo helenístico, del negocio bancario.

Para ello partimos de la Novela CXXXVI y del Edicto IX que responden al título De argentariorum contractibus (53). 
La primera de estas fuentes se refiere a la institución de la antiphonesis, en concreto, con independencia de otras formas de garantía, mientras que el Edicto IX nos proporciona datos sobre la práctica de una de sus modalidades, la antiphonesis pura probablemente muy frecuente.

El término antiphonesis es la sustantivación del verbo que significa, en general, responder a un formulación previa; en sentido jurídico se utiliza para designar una forma de garantía, es decir, el hecho de responder por otro. Este término, que sólo aparece en las Novellae (54) y que no es expresión tradicional en derecho griego (55), ha sido traducido al latín, modernamente, por constitutum (56), mientras que el receptum argentariorum vendría designado con otros términos griegos.

Ahora bien, la traducción de antiphonesis por constitutum se debe a lo establecido en la constitución reformadora, ya conocida, en la que se habla de la abolición del receptum y se dibujan nuevos perfiles para el constitutum. Dicha traducción, sin embargo, resulta discutible. En efecto, el Authenticum traduce antiphonesis por sponsio sin que ello pueda equivaler al sentido técnico en derecho clásico. Solamente en una ocasión la traduce por pecuniam constituerit vel spoponderit (57); $y$ en otra por quae fideiussa (58).

Por tanto, no se puede dar a la cuestión terminológica una importancia decisiva, pues la lengua griega no posee la exactitud del latín jurídico clásico ni la mentalidad oriental de este tiempo tiene el respeto de los juristas clásicos por las categorías conceptuales. Es preciso atender, fundamentalmente, al contenido jurídico de la institución, partiendo de lo que se nos dice en el texto.

Tras estas precisiones, vamos a definir nuestra institución. La antiphonesis pura del banquero consiste en la aceptación por éste de una deuda, actual o futura, de su cliente, obligándose a pagar en un plazo fijado (59).

Estamos ante un negocio jurídico trilateral que requiere la presencia de tres sujetos: el cliente del banquero, es decir, el deudor (60), el acreedor y el banquero que aume el pago en un plazo determinado.

Su perfección se articula en dos momentos: una orden del cliente al banquero seguida de la aceptación, por parte de éste, frente al acreedor.

Objeto del negocio es el pago de la deuda asumida por el banquero, que puede consistir en una obligación actual o futura (61); esta deuda puede referirse a una cantidad de dinero o bien a determinadas cosas (62).

No existe una referencia expresa a la forma, según la cual el banquero debe hacer su promesa al acreedor, aunque se debe pensar en un compromiso redactado por escrito. Ahora bien, por el Edicto IX pr. sabemos que la orden del cliente al banquero es hecha, a veces, por escrito (63), pero en otras ocasiones, por confianza hacia el contratante, sin ningún escrito (64), mientras que el en capítulo I se dispone que la demanda ha de ser escrita (65). En definitiva, hay que pensar que cuando la orden del cliente no constase por escrito existirían serios problemas para los banqueros en lo relativo a la obtención del reembolso.

En virtud de este negocio, el banquero queda obligado a pagar la deuda del cliente. Podemos considerar su promesa como abstracta (66), es decir, independien- 
te de la obligación del deudor principal que es su causa. El acreedor no debe probar la existencia de la obligación principal, ni el banquero pude oponerle excepciones derivadas del negocio subyacente (67), cuando se le exija el cumplimiento de la obligación.

Por consiguiente, no estamos ante un garante accesorio, un deudor añadido, como el fideiussor romano a quien se transmitían las excepciones del deudor principal (68); estamos, pues, ante un garante independiente como corresponde a la tradición griega (69). Pero esta independencia del banquero es más acusada que la del garante de la tradición griega, porque éste debía pagar si la persona por la que había salido garante no obsevaba la conducta prevista (70), mientras que el banquero venía obligado a pagar una deuda que incluso podía no ser exigible frente al deudor principal (71).

Lo anterior viene confirmado por el hecho de que el banquero podía ser demandado por el acreedor sin necesidada de haber ido previamente contra el deudor principal. Esto se opone al beneficium excussionis de la Novela IV. Pero la garantía bancaria estaba espresamente excluída de esta norma. En efecto, se puede dudar del sentido de lo que establece la Novela IV (72), porque puede significar que las garantías bancarias vendrán sujetas al nuevo orden (73) o permanecerán sujetas al orden existente (74); pero la Novela CXXXVI establece, de forma inequívoca, que el colegio de los banqueros venía excluído de la Novela IV (75). Esto da lugar a la protesta de los banqueros cuya contestación viene establecida por la Novela CXXXVI, con la que los mismos son admitidos a pactar la renuncia al beneficio de excusión (76), cuando hayan dado dinero en concepto de mutuo y hayan recibido garantes del mutuarario. Pero cuando el garante es un banquero el acreedor se dirige, en primer lugar, a él, en virtud se su solvencia y del carácter abstracto de su promesa.

Y aún hay más; en el Edicto IX, en el prefacio, se nos dice que los deudores por el hecho de asegurar su deuda reciben los documentos y recibos (77), es decir, al menos en la práctica, los acreedores liberan a los deudores principales desde el momento en que el banquero asume el pago. Estamos ante una promesa abstracta que, procedente de alguien tan solvente como el banquero, equivale para los acreedores a un pago diferido (78).

El problema para los banqueros se centra en la obtención del reembolso con respecto al deudor principal, pues si la obligación asumida por el primero no llega a nacer debe, pese a todo, pagar, no pudiendo oponer ni la querella ni la exceptio non numeratae pecuniae ni ninguna otra excepción (79).

Y el cliente deudor puede rechazar la reclamación del banquero alegando la inexistencia de la deuda (80).

A resolver las dificultades que se plantean por esta razón viene el capítulo I del Edicto IX que establece un doble sistema. En efecto, del texto en cuestión se deduce lo siguiente:

1.- Si la orden del cliente al banquero ha sido formulada por escrito, dicho cliente viene obligado, sin más, al reembolso con arreglo a lo establecido en el documento (81). 
2.- Pero si aquélla no ha sido formulada por escrito es preciso recurrir a los medios generales de prueba establecidos (82), para constatar que la garantía ha surgido por voluntad del deudor (83); en este sentido se requiere el transcurso de un plazo preestablecido en la ley, durante el cual el deudor no haya expresado ninguna queja al respecto (84).

En suma, en el supuesto de orden del cliente al banquero por escrito, el reembolso sería abstracto al igual que lo era la promesa del banquero; y en el supuesto de no haber sido fijada por escrito el reembolso sólo es abstracto desde el momento en que el banquero haya probado el encargo del deudor, con arreglo a los requisitos que ya hemos mencionado (85).

Finalmente, el deudor principal, como se desprende del capítulo II del Edicto IX, venía también obligado a pagar al banquero la retribución prevista. Para la prueba de este pacto se podría recurrir a los documentos o a los testigos. Aunque el texto no llega a establecer una presunción iuris tantum de onerosidad, subraya al menos al carácter inhabitual de la gratuidad (86).

\section{NOTAS}

1.- Es una de las leges ad commodum propositi operis pertinentes. Sobre estas constituciones, distintas de las quinquaginta decisiones, véase, LONGO, Contributo allo studio della formazione delle Pandette, BIDR, 1907, p. 145 s. DE FRANCISCI, Nuovi studi intorno alla legislazione giustinianea durante la compilazione delle Pandette, BIDR 1910, p. 155 s.; 1911, p. 186 s.; 1915 , p. $5 \mathrm{~s}$.

2.- Hemos de recordar, en este sentido, también la Paráfrasis de Teófilo.

3.- LENEL, EP, 1927, p. 132 s., quien aquí se mantiene fiel a la literatura antigua y moderna que ha hablado, genéricamente, de fusión o de ampliación del constitutum debido a la abolición del receptum.

Sin embargo, el análisis de las innovaciones introducidas con la constitución del 531 suscita dudas sobre la veracidad de las afirmaciones del Justiniano en lo referente al traspaso de elementos del receptum al constitutum, así como respecto a los motivos que hicieron posible la reforma.

4.- Ahora bien, esta opinión desconoce la sustancial diferencia entre el régimen jurídico del constitutum y el del receptum en derecho clásico. En efecto, entre ellos existirian importantes diferencias como en lo referente a la fijación de un dies certus solutionis, que no se exigiría en el receptum, o en la limitación al único supuesto de aceptación de un débito ajeno, que no es el caso del constitutum que surge y se desarrolla como constitutum debiti proprii y sólo en un segundo momento, y raramente, se admite en la hipótesis de un debitum alienum; sobre todo, en tema de la necesidad de existencia de un vínculo obligatorio previo, de una pecunia debita: mientras que en el caso de aceptación de una responsabilidad ex recepto, el banquero haría surgir una obligación autónoma y abstracta, en base a la cual el destinatario de la promesa podría dirigirse para obtener el pago et si quid non fuerat debitum.

5.- ASTUTI, Il costituto, 1941, p. 289. FREZZA, Le garanzie, 1962, p. 283.

6.- También Teófilo habla de ella como de cosa perteneciente al pasado e inusitada, Paraphr. ad 8 I. 4, 6. Incluso en el tratado helenístico prejustinianeo De actionibus. FERRINI, Sull'opuscolo greco intitolato De actionibus I, 1893, p. 366 s. llega a suponer ya producida la desaparición de la acción recepticia que falta en el catálogo.

7.- LENEL, Beiträge, 1881, p. 69. PARTSCH, Der Ediktale, ZSS 29, p. 415. CUQ, Manuel, 1928 , p. 515. 
8.- LENEL, Beiträge, cit., p. 68 s., no admite que la causa de la reforma sea el no uso del receptum.

Este autor mantiene que la fusión de constitutum y receptum habría determinado, en la práctica del mundo helenístico, la desaparición de la acción recepticia, ya que no serviría la dualidad de acciones derivada de un mismo negocio. La reforma habría consistido en la desaparición del medio procesal, pero no en la del negocio que habría sobrevivido en el mundo oriental fundido, desde el punto de vista externo, con el constitutum, en cuanto al nomen iruis. El más riguroso régimen del antiguo receptum se habría mantenido hasta Justiniano y, a pesar de la abolición formal del mismo, inciden en este mismo régimen jurídico disposiciones especiales contenidas en las Novelas aplicables a la garantía de los argentarii.

En este sentido, PARTSCH, Der Ediktale, cit., p. 412 s. (donde pone de manifiesto sorprendentes analogías entre receptum e institucines griegas) ha planteado el tema del origen del receptum argentariorum, llegando a la conclusión de que éste se encuentra en el derecho griego, considerando también que el receptum fue introducido en el Edicto del Pretor en el siglo II a. d. C. Este autor considera que el receptum es un instituto vivo en la época de justiniano y explica el tema de su abolición por las aspiraciones de los banqueros bizantinos que pretendían obtener una regulación menos rígida y gravosa de sus obligaciones, lo que viene recogido en el proemio del Edicto IX.

También PEROZZI, Ist., 1928, p. 237, considera que el receptum se ha mantenido en la práctica bizantina incluso después de la constitución del 531.

9.- COLLINET, Estudes historiques, 1912, p. $270 \mathrm{~s}$.

10.- COLLINET, Estudes, cit., p. 274. CUQ, Manuel, cit., p. 514.

11.- La investigación papirológica no ha llegado a resolver las incógnitas existentes en esta materia. MITTEIS, Receptum argentari, ZSS 29, p. 479 s., considera que dos casos de receptum vienen recogidos en P. Oxy. 91, 11 (a. 187), P. Oxy. 513, 36 (a. 184) y P. Flor. 43, 7. En contra PARTSCH, Arch. f. Pap. Forsch. 5, 1913, p. 490, que asocia el receptum con otros documentos como P. Petrie 3, 64 b, P. Lill. 16, P. Par. 9, 29 ?.

12.- En la constitución y en Teófilo se habla de la acción recepticia como de algo perteneciente al pasado. Este es un dato que se desprende de las fuentes de modo inequívoco. El enfoque puramente procesal que se da al tema confirma nuestra idea, si se piensa en la época en que el texto es promulgado.

13.- Del examen de estas fuentes se obtiene la evidencia de que, después de la reforma del 531 , al constitutum -antiphonesis- de los argentarii le es de aplicación una normativa específica distinta de la correspondiente al derecho común.

14.- Novela CXXXVI, pr. ... ut aut ipsi (argentarii) quoque communium legum participes sint, aut ne ipsis quidem constitutio nostra adversetur.

15.- Negotiatores y argenti distractores vienen considerados conjuntamente como destinatarios de esta norma. Lo mismo ocurre con c. 27 pr. C. 8,13 , mientras en c. 1 pr. 3 C. 12,34 vienen excluidos de la militia sólo los negotiatores exceptis argenti distractoribus, a los cuales se les concede una posición más favorable (Nov. IV, c. 3, 1).

En definitiva, estamos ante una norma encuadrable en el derecho mercantil helenístico y no ya en el derecho común.

16.- Según ROSSELLO, Rec. arg., 1890, p. 56 el término indefense no es usado más que en este caso en el Corpus Iuris; de aquí derivaría la multiplicidad de opiniones existentes sobre el mismo y que concretamos del siguiente modo: CUIACIUS, Comment. ad Cod. 4, 18, 1758 (IX, 241, A) explica indefense, id est ita ut nulla exceptione se tueri possint. DONELLUS, Comment. at Cod. 4, 18, 2, 1765 (VII, 1000, 20) propone sustituir por inoffense, id est sine offensa legum et iuris publici, el indefense que, según él, indicando qui iudicio non defenditur no tendría sentido. MABILLE, Arg., 1874, p. 47, dice que los argentarii, en los recepta, se encuentran "sans defense". IHERING, Espíritu del DR, 4, 1891, p. 237, relaciona indefense con renuncia a toda exepción lo que equivale a una responsabilidad absoluta y abstracta. 
17.- Llegó a pensarse que el término indefense se refería a la hipótesis en que los banqueros se encontraban en la imposibilidad de invocar la exceptio excussionis, por haber renunciado a ella. CUIACIUS, Recit. Soll. in Cod. 4, 18, 2, 1758 (IX, 241). GIPHANIUS, Explanatio, 1614, p. 250. Pero a esta interpretación se opone el hecho de que el beneficium fue introducido por la Novela IV (a. 535), mientras que el término indefense se encuentra, como sabemos, en la constitución reformadora que es de fecha anterior (a. 531).

18.- Esta interpretación corresponde, en lo fundmental, con la ofrecidas por IHERING, Espíritu, cit., p. 237 y LENEL, Beiträge, cit., p. 69, los cuales entienden el indefense constituere haciendo referencia a la antiphonesis abstracta de los argentarii; tambíen PARTSCH, Der Ediktale, cit., p. 415 y BEKKER, Recipere, ZSS 3, p. 12 n. 2.

Ahora bien, esto no comporta la identificación del constitutum hecho indefense o de la mencionada antiphonesis de las Novelas y de los Edictos de Justiniano con el receptum argentariorum del derecho romano. A esta identificación se oponen los testimonios del emperador y de Teófilo. Los banqueros bizantinos practicaban formas de garantía y esquemas negociales muy similares, quizá, a la figura romana. Piénsese que ésta habría surgido a imitación de las prácticas seguidas por los "trapezitas" griegos. Pero, exactamente no de trataba del receptum, pues el emperador no lo podría haber considerado inusitado en el momento mismo en que reconocía obligaciones especiales para banqueros y comerciantes.

19.- PARTSCH, Der Ediktale, cit., p. 413 s. BEKKER, Recipere, cit., p. 2 s.

20.- I. $4,6,8$.

21.- LEONHARD, v. Constituere en PW.

22.- COLLINET, Estudes, cit., p. 270 s.; 277 s.; 288 s. Este autor da una explicación que no parece suficiente, según la cual, la a. pec. const. sería reformada para cubrir las exigencias y necesidades de todos los pueblos que vivían bajo el derecho justinianeo. Así, se regularía, modificando los textos clásicos, no solamente al constitutum romano sino incluso, y sobre todo, las formas contractuales conformes con la práctica del Oriente helenizado. De este modo, Justiniano cedería al laudable impulso de unificar el derecho, fundiendo instituciones romanas y helenísticas que, junto a la fideiussio, servían de medios de garantía. El constitutum debiti quedaría como un instituto helenístico vestido a la romana y, además, la reforma de Justiniano, en materia de garantías personales, conservaría una forma pretoria al lado de otra civil, la fideiussio.

23.- Para precisar, diremos que en las fuentes posteriores al 531 el negocio bancario viene designado como antiphonesis pura mientras que antiphonesis es término genérico que se ha venido traduciendo por constitutum, siendo la primera una modalidad de la segunda.

24.- C. 4, 18, 2 ...Sive pro se quis constituat sive pro alio... Ni siquiera se hace mención a la limitación del receptum a los banqueros, de tal manera que los intérpretes antiguos que no conocían la Paráfrasis de Teófilo lo consideraban de aplicación general como el constitutum. ROSSELLO, Rec. arg., cit., p. 59.

25.- ASTUTI, Il costituto, cit., p. 307.

26.- C. $4,18,1$. Si pro alieno debito te solututum constituisti pecuniae constitutae actio non solum adversus te, sed etiam adversus heredes tuos perpetuo competit (a. 294).

27.- Fr. Vat. 55.

28.- Véase la genérica fórmula contenida en Ed. IX proem, de Justiniano.

29.- D. $13,5,1,6$.

30.- El papel que representan en este escenario cada uno de los "personajes" podría concretarse del siguiente modo:

a) Receptum argentariorum, inusitado instituto romano que ha de se eliminado del Digesto.

b) Constitutum, institución de Derecho romano que sufre una extensión de su campo de aplicación y que, como tal, aparece recogida en el Digesto.

c) La antiphonesis pura, institución de derecho bancario helenístico, en plena vigencia, que viene siendo desarrollada por las Novelas. Es una modalidad de la antiphonesis en sentido de garantía general. 
Las dificultades que genera la confusión terminológica en este tema pueden llevar a no entender la individualidad de cada una de estas instituciones en cuanto a su naturaleza jurídica.

31.- COLLINET, Etudes historiques I, cit., p. $270 \mathrm{~s}$.

32.- ASTUTI, Il costituto, cit., p. 315.

33.- KARLOWA, Rom. R. Gesch., 1885, p. 758. PARTSCH, Der Ediktale, cit., p. 412, habla de similitud entre receptum y stipulatio, ya que el consitutum es reformado en relación con la abolición del receptum, equiparándolo a la stipulatio. También en el texto paralelo de Basílicos (26, 3, 2 HEIMB. III p. 109) se reproduce la referencia a la stipulatio, mientras del receptum no se hace mención alguna.

34.- SEGRE, Le garanzie personali, 1933, p. 269 n. 1.

35.- Una confirmación de cuanto venimos diciendo la encontramos en I. 4, 6, 9: ...de pecunia constituta cum omnibus agitur, quicumque vel pro se vel pro alio soluturos se constituerit, nulla scilicet stipulatione interposita nam alioquin si stipulandi promiserint, iure civili tenentur.

36.- LONGO, Natura actionis nelle fonti bizantine, BIDR 17, p. 34 s. y $78 \mathrm{~s}$.

37.- LEVY, Weströmisches Vulgarrecht, 1956, p. 196. KASER, Das römische Privatrecht, 1975, p. $330 \mathrm{~s}$.

38.- Gayo 3, 115: pro eo quoque, qui promittit, solent alii obligari, quorum alios sponsores, alios fidepromissores, alios fideiussores apellamus.

39.- LEVY, Weströmisches, cit., p. 56 s. y 196 s. DE MARTINO, Le garanzie, 1937-1938, p. 35 s. FREZZA, Le garanzie, cit., p. 34.

40.- FREZZA, Le garanzie, cit., p. $35 \mathrm{~s}$.

41.- ARCHI, Contributi alla critica del Corpus Iuris, BIDR 1962, p. 134.

42.- ASTUTI, Il costituto, cit., p. $315 \mathrm{~s}$.

43.- En este sentido se manifiesta FREZZA, Le garanzie, cit, p. $282 \mathrm{~s}$.

44.- ASTUTI, Il costituto, cit., p. 30 s., p. 134 s. FREZZA, Le garanzie, cit., p. 248-249.

45.- LEVY, Weströmisches, cit., p. 88 s. KASER, Das römische Privatrecht, cit., p. 64 s. ARCHI, v. "Condizione" en Enciclopedia del Diritto.

46.- ARCHI, Contributi, cit, p. 143.

47.- ASTUTI, Il costituto, cit., p. 79 s. FREZZA, Le garanzie, cit., p. 229 s. En contra VOCI, Risarcimento e pena privata nel diritto romano classico, 1939, p. 149.

48.- FREZZA, Ob. cit., p. 229 s.

49.- ARCHI, Contributi, cit., p. 144.

50.- AMELOTTI, La prescrizione delle azioni in diritto romano, 1958, p. 224.

51.- ASTUTI, Il costituto, cit., p. $281 \mathrm{~s}$.

52.- C. Cordi, I.

53.- VAN DER WAL, Manuale Novellarum Iustiniani, 1964, p. 11, ha puesto de manifiesto las dificultades para determinar la fecha de estas disposiciones.

54.- No se encuentra el término en BORTOLUCCI, Index verborum graecoum quae in Institutionibus et Digestis occurrunt, 1906, ni en MAYR, Vocabularium Codicis Iustiniani II, 1925.

55.- No aparece en BEAUCHET, Histoire du Droit Privé de la République Athénienne IV, 1887, p. $565 \mathrm{~s}$.

56.- MITTEIS, Receptum argentarii, ZSS 29, p. 479-480. SCHOLL y KROLL, Corpus Iuris Civilis III, 1954. TAUBENSCHLAG, Geschichte der Rezeption des romischen Privatrechts in Aegypten, Studi Bonfante I, 1930, p. 431 y The Law of Greco-Roman Egypt in the light of the papyri, 1955 , p. 415.

57.- Nov. CXV, 6, p. 548 línea 7.

58.- Nov. CXLVII, 2, p. 720 líneas 27 y 28.

59.- DIAZ-BAUTISTA, Les garanties bancaires dans la législation de Justinien, RIDA 1982, p. 175. 
60.- Ed. IX, pr., p. 772 línea 10.

61.- Ed. IX, pr., p. 772 línea 9.

62.- Ed. IX, pr., p. 772 línea 10.

63.- Ed. IX, pr., p. 772 línea 11.

64.- Ed. IX, pr., p. 772 líneas 11 y 12.

65.- Ed. IX, cap. I, p. 773 línea 7.

66.- DIAZ-BAUTISTA, Les garanties, cit., p. 177.

67.- Esta interpolación se basa en lo establecido en pr. p. 772 línea 28 y p. 773 líneas 1 y 2 . La abstracción se confirma por el hecho de que el pago lo efectuaba el banquero sin exigir pruebas del nacimiento de la deuda, Ed. IX, pr., p. 772 línea 17. También porque el deudor principal queda liberado en virtud de la promesa bancaria, Ed. IX, pr., p. 772 línea 16.

68.- I. 4,14 , 4; C. J. 8, 35, 11; D. $44,1,7$, 1; D. 44,1 , 19; D. 46, 1, 32; D. 2, 14, 21, 5; D. 2 , $14,27,1-2$; D. $17,1,29$ pr.; D. $34,3,5$ pr.; D. $46,3,95,12$; D. $2,15,7,1$; D. $46,1,68,2$; D. 46,1 , 15 pr.; D. 46, 1, 46 pr.; C. J. 4, 30, 12; C. J. 4, 30, 15; D. 16, 1, 16, 1; D. 16, 1, 19, 5; D. 14, 6, 7, 1; D. $14,6,9,3$; D. $39,5,24$; D. $44,1,8$; D. $12,2,28,1$.

69.- BEAUCHET, Histoire, cit., p. 462 FREZZA, Le garanzie, cit., p. 33. WOLFF, Griechisches Recht v. Recht en Lexicon der Alten Welt (Artemis), 1965. PARTSCH, Griechisches Bürgschaftrecht, 1909, p. 29 s. CANTARELLA, La fideiussione reciproca, 1965, p. 48.

70.- En la dogmática actual se podría decir que la obligación del garante está sometida a condición potestativa negativa.

71.- DIAZ-BAUTISTA, Les garanties, cit., p. 178.

72.- Novela IV, 3, 1.

73.- El Authenticum traduce in ordine moderno mansuris.

74.- SCHOLL y KROLL traducen de manera ambigua in eo qui nunc est ordine mansuris.

75.- Novela CXXXVI, pr.

76.- Novela CXXXVI, 1, p. 691 línea 21.

77.- Ed. IX, pr., p. 772 línea 16.

78.- DIAZ-BAUTISTA, Les garanties, cit., p. 179.

79.- El banquero no es un verdadero fideiussor, por lo que no puede oponer las excepciones correspondientes al deudor.

80.- Son muy problemáticas en este caso la condictio indebiti y la cesión de acciones del acreedor al banquero. DIAZ-BAUTISTA, Ob. cit., p. 181-182.

81.- Ed. IX, 1, p. 773 línea 15.

82.- Ed. IX, 1, p. 773 línea 16.

83.- Ed. IX, 1, p, 773 líneas 12 y 13.

84.- Ed. IX, 1, p. 773 líneas 10 y 11. Ello tendría lugar mediante la interposición de la querella non numeratae pecuniae del cliente frente al banquero.

85.- DIAZ-BAUTISTA, Les garanties, cit., p. 184. El banquero mediante su promesa da seguridad al acreedor de que la deuda va a ser pagada, con lo que cumple una importante función en el comercio; pero a la vez el banquero cuenta, desde el primer momento, con la posibilidad de obtener el reembolso frente al deudor principal.

86.- Ed. IX, 2, p. 773 líneas 20 y 21. VAN DER WAL, Manuale Novellarum Iustiniani, cit., p. $105 \mathrm{n} .3$, cree que se trata probablemente de una interpretación errónea de la regla mandata gratuita esse debent. En efecto, la gratuidad del mandato viene afirmada en Gayo 3, 162; D. 17, 1, 1, 4; D. 17, 1, 36, 1 y en Inst. 3, 26, (27), 13; pero no se trata de una regla absoluta. En este sentido ARANGIO-RUIZ, Il mandato in Diritto romano, 1963, p. $114 \mathrm{~s}$. 


\title{
INCIDENCIA DE LA LEY 11/1981 EN MATERIA DE SUCESIONES
}

\author{
Dr. LUIS FERNANDO SAURA
}

Parafraseando el artículo 3,1 del Código Civil, yo diría que las normas no sólo se interpretarán, sino también se elaborarán... en relación con el contexto, antecedentes históricos y legislativos y la realidad social del tiempo en que han de ser aplicadas.

En efecto nada existe tan cambiante y relativo como la norma jurídica, siempre en vigilia como el buho de Minerva, espectador atentísimo de algo para ella, tan significativa y vertiginosamente cambiante cual es la realidad social en cada lugar y en cada tiempo.

De aquí el título genérico del Ciclo de conferencias y mesa redonda que organiza el Colegio de Abogados: "Las leyes reformadoras del Código Civil de 1981: Respuesta legal y pauta informadora del cambio normativo civil".

De aquí también el escogido para esta mi brevísima intervención que, a manera de taracea, pretendo incrustar -para su relieve, participando del mérito ajeno- en la magistral lección que, inmediatamente, impartirá el Profesor Albadalejo.

Manifiesto lo anterior e iniciando la aproximación al tema, considero -como casi todos los que a estos menesteres nos dedicamos- que las reformas del Código Civil de 1981 han sido sólo un hito, un eslabón -aunque de enorme importancia, sin duda- más en esa cadena de modificaciones y adecuaciones de nuestro Código a lo largo de su amplio siglo de existencia. Mas como tiempo y circunstancias imponen límites, quiero destacar, de las anteriores a 1981, únicamente las de 24 de abril de 1958 y la de 2 de mayo de 1975, en tanto marcan la impronta a seguir y desarrollar por las posteriores, como fueron las que nos ocupan y como lo han sido las de incapacitación e instituciones tutelares de 1983, la de adopción de 1987, la de 1990 eliminando espresiones discriminatorias residuales, y como lo serán las que ahora se están debatiendo en Las Cortes en sede de testamentos por ejemplo.

Curiosamente, cuando nos referimos a las reformas de 1981 parece cual si sólo hubieran hecho mella en nosotros las modificaciones específicamente referidas al Derecho de familia, olvidando la significativa y transcendental incursión en materia de sucesiones, reformando -a veces únicamente suprimiendo referencias ya inadecuadas, pero otras produciendo mutaciones radicales mediante el incisivo bisturí que amputa y elimina lo caduco, implantando lo actual y vigente- nada menos que 46 artículos, y suprimiendo tres de ellos en concreto los números 836, 952, 953.

Obviamente la incidencia en el Derecho de sucesiones obtiene su savia nutricia del giro copernicano que, en especial la Ley de 13 de mayo de 1981, imprime al Código Civil en lo referido a relaciones conyugales y paterno-filiales. 
A ambas vertientes nos referimos seguidamente, cotejando lo de antaño con lo de hogaño, sucintamente y sólo en cuanto sea menester para mejor entendimiento de la normativa que nos ampara. De esta suerte, habremos de aludir a hijos y cónyuges, a sucesión testada e intestada.

\section{1.- De las distintas clases de hijos y de su actual igualdad:}

\section{A.- Normativa anterior a la Ley 1111981.}

De manera global podían reducirse a tres las clases de hijos referidos en la legislación anterior a 1981: Legítimos; legitimados; ilegítimos.

Dentro de las dos segundas categorías existían subdivisiones, como veremos, cuyos efectos, relaciones familiares, derechos y nom.inaciones variaban hasta crear en esta última vertiente, un riquísimo rimero de sustantivos, tan cruelmente escogido como exacto -hay que reconocerlo- en su aplicación.

A los hijos legítimos se referían los artículos 108 y siguientes del Código.

A los legitimados algunos otros, de los que, a manera de botón de muestra, transcribimos los siguientes:

Artículo 119.- "Sólo podrán ser legitimados los hijos naturales. Son hijos naturales los nacidos, fuera del matrimonio, de padres que al tiempo de concepción de aquéllos pudieron casarse con dispensa o sin ella".

Artículo 120.- "La legitimación tendrá lugar:

$1^{\circ}$.- Por el subsiguiente matrimonio.

$2^{\circ}$.- Por concesión Real". (El tradicionalmente conocido como Rescripto del Príncipe).

Artículo 122.- "Los legitimados por subsiguiente matrimonio disfrutarán de los mismos derechos que los hijos legítimos".

Artículo 127.- "La legitimación Real dá derecho al legitimado: ....3ํ․- A la porción legitimaria que establece este Código".

Relativamente a los llamados hijos ilegítimos, distinguía el Código entre los naturales y los demás, estableciendo, al respecto:

Artículo 129.- "El hijo natural puede ser reconocido por el padre y la madre conjuntamente, o por uno solo de ellos".

Artículo 134.- "El hijo natural reconocido tiene derecho: "....3‥- A percibir, en su caso, la porción hereditaria que se determina en este Código".

Más que distinta y lastimosa era la suerte de los "llamémosles" hijos ilegítimos ilegítimos, como nos muestra el Artículo 139: "Los hijos ilegítimos en quienes no concurran la condición legal de naturales, sólo tendrán derecho a exigir a sus padres alimentos, conforme al artículo 143".

Junto a los hijos biológicos o de sangre han compartido filialidad -con más o menos equiparación, con más o menos derechos según los tiempos y las costumbres- los llamados hijos adoptivos.

(Es famosa la anécdota sobre la forma de llegar al Código la figura -tan rabiosamente de actualidad en los tiempos que corren- de la adopción. Se cuenta, en efecto, 
que la Comisión de Códigos que redactó el Proyecto de 1851, a p’unto estuvo de relegarla al más absoluto de los olvidos. Sin embargo, a última hora y al decir de García Goyena, salvose de tan triste suerte pues que un vocal, hijo de Andalucía, manifestó que en su tierra se daban algunos casos de ella, si bien bastante raramente).

Olvidando nosotros también tiempos pasados -que aún a pesar de Manrique no siempre fueron mejores- haremos ligera referencia a la adopción tal como regulara la Ley de 4 de julio de 1970.

Como sabemos, distinguía ésta entre adopción plena y menos plena o simple.

Respecto de la primera disponía el Artículo 179: "El hijo adoptivo acupa en la sucesión del adoptante la misma posición que los hijos legítimos, con las siguientes particularidades: $1^{\underline{a}}$.- concurriendo sólo con hijos ilegítimos y tratándose de sucesión testamentaria no podrán percibir por mejora más que el hijo legítimo menos favorecido. $2^{\circ}$.- Si concurrieren con hijos naturales reconocidos, cada uno de éstos no podrá percibir menos porción que el adoptivo. Los adoptantes ocuparán en la sucesión del hijo adoptivo la posición de los padres legítimos. Los parientes por naturaleza no ostentarán derechos por ministerio de la Ley en la herencia del adoptado, sin perjuicio de lo dispuesto en el artículo 812 del Código.

En cuanto a la adopción simple, afirmaba el párrafo final del Artículo 180: "El hijo adoptivo ocupa en la sucesión del adoptante la misma posición que los naturales reconocidos. El adoptante ocupa en la sucesión del hijo adoptivo una posición aquivalente a la del padre natural.

B.- Consideración de los hijos tras la ley de 13 de mayo de 1981.-

Dispone el artículo 39 de nuestra Constitución:

1.- Los poderes públicos aseguran la protección social, económica y jurídica de la familia.

2.- Los poderes públicos aseguran, asimismo, la protección integral de los hijos, iguales éstos ante la Ley, con independencia de su filiación, y de las madres, cualquiera que sea su estado civil.

3.- Los padres deben prestar asistencia de todo orden a los hijos habidos dentro o fuera del matrimonio, durante su minoría de edad y en los demás casos en que legalmente proceda.

4.- Los niños gozarán de la protección prevista en los acuerdos internacionales que velan por sus derechos".

Siguiendo las pautas marcadas por el referido artículo constitucional, por Ley 11/1981 se redactó el artículo 108 del Código Civil, en la forma que se recoge: "la filiación puede tener lugar por naturaleza y por adopción. La filiación por naturaleza puede ser matrimonial o no matrimonial. Es matrimonial cuando el padre y la madre están casados entre sí. La filiación matrimonial y la no matrimonial, así como la adoptiva plena, surten los mismos efectos, conforme a las disposiciones de este Código".

Si bien carece de toda relevancia -al menos en el orden de los alimentos, y de la 
sucesión- la distinta procedencia de los hijos -matrimoniales, no matrimoniales y adoptivos- siguen existiendo reminiscencias de tiempos pasados en nuestro Código. Así, quién no relaciona inmediatamente el anterior artículo 120 referido a la legitimación por subsiguiente matrimonio, con el actual 119, cuando nos dice: "La filiación adquiere el carácter de matrimonial desde la fecha del matrimonio de los progenitores cuando éste tenga lugar con posterioridad al nacimiento del hijo, siempre que el hecho de la filiación quede determinado legalmente conforme a lo dispuesto en la sección siguiente..."

En lo concerniente a adopción, la Ley 21/1987 de 11 de noviembre le da nueva regulación, cuyas líneas básicas podrían resumirse en: a) Acaba con la distinción anterior entre adopción plena y simple; b) confirma la disposición del artículo 108 del Código en su redacción actual llevando a una equiparación total con el resto de los hijos biológicos y condigna inserción plena en la familia adoptante, como lo prueban, entre otros, el artículo 178 del Código Civil en su párrafo primero especialmente, diciendo: "La adopción produce la extinción de los vínculos jurídicos entre el adoptado y su familia anterior..." o el número 4 del artículo 180, al determinar: "La determinación de la filiación que por naturaleza corresponda al adoptado no afectará a la adopción".

Todo ello tiene su reflejo, naturalmente, en lo referido a patria potestad, alimentos, sucesión, etc. como se verá oportunamente.

\section{2.- De los derechos del cónyuge viudo.}

\section{A.- Breve referencia histórica:}

Sabido es que en el derecho germánico, la preocupación en torno al principio de troncalidad, a la permanencia de los bienes en el tronco familiar de procedencia, se traducía en una indisimulada aversión a la sucesión mortis causa en favor del cónyuge viudo, quién, al hacerlos suyos, podía dirigirlos a su propia familia. En la búsqueda de fórmulas conciliatorias entre troncalidad y protección al cónyuge sobreviviente, las más frecuentes eran, ya establecer regímenes económico-matrimoniales con participación en los bienes adquiridos constante matrimonio, ya constituir, en favor del cónyuge viudo, usufructo sobre los bienes.

Tampoco en Derecho romano andaba en exceso beneficiado el cónyuge viudo a la hora de competir con los parientes del premuerto en el reparto de bienes fallecido éste abintestato, siguiéndose en tales eventos, el orden jerárquico siguiente:

$1^{2}$.- Descendientes legítimos tanto del lado paterno como del materno. (En atención a quien fuere el fallecido, lógicamente).

$2^{\mathrm{a}}$ - Ascedendientes paternos y maternos, hermanos y hermanas carnales, y descendientes de estos últimos.

3a.- Hermanos y hermanas consanguíneos, hijos del mismo padre, pero de madres distintas o uterinos y sus descendientes.

4⿳亠丷. - Cognados tanto del lado paterno como del materno. Las Novelas no precisan si existe la limitación al sexto y séptimo grado.

5a.- Las Novelas no hablan de la sucesión del cónyuge cobreviviente que, sin embargo, parece admitida a falta de cognados. (1). 
En la misma línea justinianea, y con su peculiarísimo y entrañable romance, nos dirá la Partida Sexta, Título XIII, Ley Sexta: "...E sobre todo esto dezimos, que si alguno muriesse sin testamento, que non ouiesse parientes, de los que suben o descienden por la liña derecha, nin ouiesse hermano, nin sobrino fijo de su hermano, que destos adelante el pariente que fuere fallado que es mas cercano del defunto hasta en el dezeno grado, esse heredera todos sus bienes. E si tal pariente non fuesse fallado, E el muerto auia muger legitima, quando fino heredara ella todos los bienes de su marido, esso mismo dezimos del marido que heredara los bienes de su muger en tal caso como este. E si por auetura el que assi muriesse sin parientes non fuesse casado, estonce heredara todos sus bienes la camara del Rey". (2).

Entiende Lacruz Berdejo (3) estable la situación que hemos dejado expuesta, hasta la Ley de Mostrencos que coloca, dice, al viudo después del cuarto grado de la línea colateral, con una reserva de los bienes raices de abolengo.

Señala Díez-Picazo, a este propósito, que reiterada jurisprudencia del T.S. iniciada en 1893 y sostenida hasta 1958, se decantaba en pro del entendimiento de haber sido derogado el derecho especial de los territorios forales por la referida Ley de Mostrencos, y que, por consecuencia, en cuanto vino el Código a sustituir a meritada Ley, establecía un régimen unitario para todos, en sede de sucesión intestada. Argumento endeble para Diez-Picazo en tanto que si bien la Ley de Mostrencos tenía carácter general en alguno de los llamamientos sucesorios abintestato que hacía -fundamentalmente el del Estado- dejaba intacta el resto del contenido de la institución. Termina el autor señalando la superfluidad acual de la discusión, tras la aparición de las Compilaciones de los Derechos Civiles especiales, confirmando la subsistencia de normas forales relativas a este tipo de sucesión.(4).

En todo caso, lo que es innegable es que el Código Civil mejoró sensiblemente la situación del cónyuge viudo, al concederle -en su versión inicial 1888-1889- unos considerables derechos legitimarios en concurrencia con hermanos del causante; y en la sucesión intestada a falta de hermanos o sobrinos hijos de tales hermanos del cónyuge fallecido, una posición que, si nó envidiable, mejoraba manifiestamente la que ocupaba antes.

\section{3.- Factores básicos del cambio normativo.}

Tras la lectura del artículo 14 de la Constitución: "Los españoles son iguales ante la Ley, sin que puede prevalecer discriminación alguna por razón de nacimiento, raza, sexo, religión, opinión, o cualquier otra condición o circunstancia personal o social.

$\mathrm{Si}$, seguidamente, espigamos algunos párrafos del ya citado artículo 39 de la Constitución, como, por ejemplo:"...Los poderes públicos aseguran, asimismo, la protección integral de los hijos, iguales éstos ante la Ley con independencia de su filiación..." "Los padres deben prestar asistencia de todo orden a los hijos habidos dentro o fuera del matrimonio..."

¿Era posible redactar de forma distinta a cómo se ha realizado por ley 11/1981 el artículo 108 del Código Civil, sin infringir paladinamente la Constitución?. 
Siendo evidente que la Constitución se limitó, en este punto, a recoger un clamor popular en favor de los seres más indefensos, aquellos fruto de un capricho, de un deseo, traidos sin su anuencia y en tantas ocasiones abocados al desamparado, a una existencia miserable.

Relativamente al cónyuge, apunta del propio modo atinadamente Lacruz Berdejo, (5) la ampliación de derechos ahora concedida por el legislador al mismo desde la reforma de 1981, se inscribe en la línea de creciente conyugalidad y reducción de la familia (familia nuclear) en la cual los lazos de afectos son, en principio, mayores entre los cónyuges que entre los hermanos. (Afirmación que, acaso, un tantico radical, encajaría mejor para el habitante de la gran urbe que apenas se relaciona con sus parientes, más que el de los pueblos. Pero -y no converdría echarlo en saco roto- ¿hay mayores rencores, odios y enfrentamientos que aquellos entre hermanos tratándose de herencias?.

Tras lo dicho, sin embargo, queda una especie de sabor amargo, de insatisfacción, de alguna pieza que no encaja en este "puzzle" de la reforma de 13 de mayo de 1981, y así lo pone de manifiesto Torres Lana (6), cuando, bajo el epígrafe "La tensión filiación familia", escribe: "Antes de la reforma, tanto el régimen jurídico de la filiación como el de la familia eran objeto de una regulación de extrema y cuidadosa coherencia. Aunque fueran discutibles algunos de sus presupuesto ideológicos, lo cierto es que su desenvolvimiento práctico tenía lugar en perfecta sincronía... Un correcto planteamiento de la reforma, dentro del ámbito estrictamente técnico hubiera exigido enfrentar, comparar y ponderar los intereses correspondientes a los dos "status" enfretados (hijos-familia) ...Las consecuencias del régimen instaurado sugieren claramente una simple disyuntiva: o quiebras el principio o protección a la familia matrimonial, o se traslada el centro de protección y la propia noción de familia a la biológica o de hecho, criterio este último que pudiera verse propiciado por la redacción del taxto constitucional ...El legislador de la reforma parece haber optado por esta segunda solución: sin embargo, su admisión acrítica no es nada fácil para un jurista...".

\section{De la sucesión forzosa.}

\section{A.- Normativa anterior a 1981.}

Hemos apuntado que uno de los momentos decisivos de la dialéctica modificadora de nuestro Código Civil, fue la Ley de 24 de abril de 1958 Fue, sin duda, el gérmen de la radical transformación sufrida por la normativa civil en sede de familia y sucesiones.

Precisamente ella redacta los artículos en la forma que pasamos a transcribir.

1.- Herederos forzosos. Los eran, a tenor del artículo 807: "1ํ․ Los hijos y descendientes legítimos respecto de sus padres y ascendientes legítimos. $2^{\circ}$. A falta de los anteriores, los padres y ascendientes legítimos respecto de sus hijos y descendientes legítimos. $3^{2}$. El viudo o viuda, los hijos naturales legalmente reconocidos y el padre o madre de éstos, en la forma y medida que establecen los artículos 834 a 842 y 846 . 
(Por razones de espacio, y en tanto se hará referencia a ello con posterioridad, excusamos la transcripción de los artículos que hacían referencia a hijos y descendientes legítimos y a padres y ascendientes también legítimos).

2.- Derechos del cónyuge viudo.

Artículo 834.- El cónyuge que al morir su consorte no se hallare separado o no lo estuviere por culpa del difunto, si concurre a la herencia con hijos o descendientes, tendrá derecho al usufructo del tercio destinado a mejora.

Artículo 835.- Cuando estuvieren los cónyuges separados en virtud de demanda, se esperará al resultado del pleito. Si entre los cónyuges separados hubiere mediado perdón o reconciliación, el sobreviviente conservará sus derechos..

Artículo 836.- En el caso de concurrir hijos de algún matrimonio anterior del causante, el usufructo correspondiente al cónyuge viudo recaerá sobre el tercio de libre disposición. En tal supuesto, si hubiere hijos naturales se adjudicará a éstos su legítima en nuda propiedad y si, mientras dure el usufructo, estuvieren en el caso de necesitar alimentos, tendrán derecho a exigirlos a todos los legitimarios en proporción a su haber hereditario".

Artículo 837.- No existiendo descendientes pero sí ascendientes, el cónyuge sobreviviente tendrá derecho al usufructo de la mitad de la herencia.

Artículo 838.- No existiendo descendientes ni ascendientes el cónyuge tendrá derecho al usufructo de los dos tercios de la herencia.

3.- De los derechos de los hijos ilegítimos.

Artículo 840.- Cuando el testador deje hijos o descendientes legítimos e hijos naturales legalmente reconocidos, tendrá cada uno de éstos derecho a la mitad de la cuota correspondiente a cada uno de los hijos no mejorados, siempre que quepa dentro del tercio del libre disposición, del cual habrá de sacarse, deduciendo antes los gastos de entierro y funeral. Los hijos legítimos podrán satisfacer la cuota que corresponda a los naturales en dinero o en otros bienes de la herencia a justa regulación".

Artículo 841.- "Cuando el testador no dejare hijos o descendientes pero sí ascendientes legítimos, los hijos naturales reconocidos tendrán derecho a la cuarta parte de la herencia. Esto se entiende sin perjuicio de la legítima del cónyuge viudo, que concurriendo con hijos naturales reconocidos, será un tercio de la herencia en usufructo, que se adjudicará a éstos en nuda propiedad mientras viviere el viudo, lo que les falte para completar la legítima".

Artículo 842.- "Cuando el testador no dejare descendientes ni ascendientes legítimos, los hijos naturales reconocidos tendrán derecho a la tercera parte de la herencia".

Artículo 843.- "Los derechos reconocidos a los hijos naturales en los precedentes artículos se transmiten por muerte a sus descendientes legítimos".

Artículo 844.- La porción legitimaria de los legitimados por concesión Real será la misma establecida por la Ley en favor de los hijos naturales reconocidos".

Artículo 845.- Los hijos ilegítimos que no tengan la calidad de hijos naturales sólo tendrán derecho a los alimentos". 
4.- De los hijos adoptivos.

Damos por reproducido el artículo 179, en su redacción por Ley de 4 de julio de 1970, que trancribimos líneas atrás.

\section{B.- Estado de la cuestión tras la Ley 11/1981.}

1.- Herederos forzosos.

Artículo 807.- Son herederos forzosos: $1^{\circ}$. Los hijos y descendientes, respecto de sus padres y ascendientes. $2^{\circ}$. A falta de los anteriores, los padres y ascendientes respecto de sus hijos y descendientes. $3^{\circ}$. El viudo o viuda en la forma y medida que establece este Código".

Con referencia a la redacción anterior conviene destacar: a) Supresión de toda referencia a legitimidad; b) Asimismo, exclusión de los hijos naturales legalmente reconocidos y de sus padres.

\section{2.- Derechos del cónyuge viudo.}

Persisten, con idéntica redacción, los artículos 834 y 835 .

Se suprimió el artículo 836 , por la razón que se verá al referirnos a los hijos naturales.

Se añade un párrafo segundo al artículo 837, del tenor siguiente: "Igual extensión tendrá el usufructo cuando los únicos herederos forzosos que concurran con el viudo o viuda sean hijos sólo de su consorte concebidos constante el matrimonio de ambos. La cuota usufructuaria recaerá en este caso sobre el tercio de mejora, gravando el resto el tercio de libre disposición".

No se produce modificación alguna en el artículo 838 ya transcrito, ni en el siguiente que pasamos a plasmar:

Artículos 839.- Los herederos podrán satisfacer al cóyuge su parte de usufructo asignándole una renta vitalícia, los productos de determinados bienes, o un capital en efectivo, procediendo de común acuerdo, $y$, en su defecto, por virtud de mandato judicial. Mientras esto no se realice estarán afectos todos los bienes de la herencia al pago de la parte de usufructo que corresponda al cónyuge".

Por último, el artículo 840 que venía a ser el primero de los dedicados a los derechos hereditarios de los hijos naturales legalmente reconocidos, es ahora el que cierra los dedicados a los del cónyuge viudo, disponiendo: "Cuando se esté en el caso previsto por el párrafo segundo del artículo 837, el cónyuge podrá exigir que el usufructo que grave la parte que reciban los hijos le sea satisfecho, a elección de éstos, asignándole un capital en dinero o un lote de bienes hereditarios".

Lo escrito en párrafos anteriores sugiere una serie de reflexiones que interesa anotar:

a.- Es incomprensible la inalteración del artículo 834 en tanto confiere derechos hereditarios al cónyuge inocente y priva de ellos al culpable de la separación, siendo así que, a la luz de la normativa actual, si, ciertamente, existen causas de separación imputables a una sólo de los cónyuges, ni el texto legal conduce a tan radicales consecuencias, ni Juzgado o Tribunal alguno desde la vigencia de las reformas de 1981 
se ha pronunciado nunca sobre la inocencia o culpabilidad de los litigantes para sancionarle con tal medida.

Únicamente podría citarse el caso -y desde luego muy alejado en sus consecuencias a la que nos ocupan- del artículo 95, párrafo segundo del Código, diciendo: "Si la sentencia de nulidad declara la mala fe de uno solo de los cónyuges, el que hubiera obrado de buena fe podrá optar por aplicar en la liquidación del régimen económico matrimonial las disposiciones relativas al régimen de paticipación y el de la mala fe no tendrá derecho a participar en las ganancias obtenidas por su consorte".

En concordancia con ello, había también de dejarse incólume el artículo 835, disponiendo en su párrafo primero: "Cuando estuvieren los cónyuges separados en virtud de demanda, se esperará al resultado del pleito". Elemental, si la sentencia declaraba la culpabilidad del difunto conservaría el cónyuge supérstite sus derechos; y al contrario. supuesto el del artículo 835 que seguramente no se dará en exceso en la práctica, pues, fallecido uno de los litigantes, el Juez, con suspensión del procedimiento, llamará a sus herederos a mantener sus acciones o excepciones; lo que -por no extendernos más en tema que, por otra parte, merecía un trabajo minucioso y asaz interesante- resultaría no sólo diabólico, sino un auténtico galimatías procesal en tema de legitimación.

Lo más racional en hipótesis como éstas, hubiera sido la supresión del artículo 834 y la aplicación "mutatis mutandi" a todo tipo de sucesiones, del artículo 945 en su actual redacción.

b.- Tampoco es de fácil inteligencia el agregado párrafo segundo al artículo 837, pues si se parte del principio constitucional de la igualdad de todos los hijos, no se entiende bien porqué unos -los del artículo 837- deben ceder más o recibir menos, que otro, es los del artículo 807).

Puede parecer un dislate por mi parte la aseveración que sigue, pero ¿es posible que el legislador no cayera en la cuenta de que previamente a la división y adjudicación del caudal hereditario hay que proceder a la liquidación de la sociedad de gananciales -si la hubiere, claro-?

Produce la impresión el párrafo que nos ocupa de que, o bien el legislador quiso, de alguna forma, sancionar "el pecado" del cónyuge libertino, o que no quisiera se beneficiaran en la misma medida el hijo de uno solo que los del matrimonio; cual si hubieran de entrar en el mismo saco todos lo bienes habidos durante la convivencia conyugal.

c.- Mientras afirma el artículo 838: "No existiendo descendientes ni ascendientes el cónyuge tendrá derecho al usufructo de los dos tercios de la herencia", dispone el 944: "En defecto de ascendientes y descendientes, y antes que los colaterales, sucederá en todos los bienes del difunto el cónyuge sobreviviente".

Aunque no puede existir confusión alguna sobre tales artículos, no está de más puntualizar que el 838 ser refiere a sucesión testamentaria -y, en efecto, se ha testado- mientras que se incribe el 944 en la intestada.

\section{3.- Pago de la porción hereditaria en casos especiales.}

En su redacción anterior a 1981, la sección $8^{\mathrm{a}}$ del Capítulo II referido a la 
herencia, se inscribía bajo el título "De los derechos de los hijos ilegítimos", y comprendía desde el artículo 840 al 847 , inclusives.

Tras la reforma referida, el artículado quedaba vacío de contenido ante la equiparación, a todos los efectos de los, antaño, diferentes clases de hijos. ante ello la disyuntiva consistía en suprimirlos o encajar en su artículado una nueva normativa. Ésta fue la solución escogida, comenzando por variar el epígrafe, trasladar el artículo 840 a la sección anterior, y rellenar los siguientes, hasta el 847, con nuevas normas armónicamente justificadoras del estrenado encabezamiento de la sección.

Un resumen apresurado, y por tanto incompleto, de las líneas básicas reguladoras de la cuestión, podría exponerse en los puntos que siguen:

a.- Posibilidad de adjudicación, total o parcial, de los bienes hereditarios a alguno de los hijos o descendientes, quien deberá satisfacer, en metálico, su porción hereditaria a los demás legitimarios.

b.- El receptor de los bienes hereditarios, obligado a pagar en metálico la cuota legitimaria a sus hermanos, puede exigir su satisfacción en bienes hereditarios, en cuyo caso se observará lo dispuesto en los artículos 1058 a 1060 del Código.

c.- La partición de que se hace mérito en los dos párrafos anteriores, requiere aprobación judicial, salvo confirmación expresa de todos los legitimarios.

d.- la decisión del pago en metálico deberá ser comunicada a los interesados en el plazo de un año desde la apertura de la sucesión. El pago habrá de realizarse, salvo pacto en contrario, dentro de término de un año máş̧ Los perceptores gozarán de las garantías establecidas en favor del legatario de cantidad. Transcurrido el plazo sin haberse realizado el pago, se precederá al reparto de la herencia conforme a las disposiciones del Código sobre partición.

e.- La fijación del metálico a satisfacer se realizará atendiendo al valor que tengan los bienes al tiempo de la liquidación, habiendo cuenta de los frutos e intereses hasta entonces producidos. Desde la liquidación, devengará el crédito metálico el interés legal.

\section{4.- En torno a preterición.}

A.- Normativa anterior a 1981.

Por disposición del artículo 814 del Código, "la preterición de alguno o de todos los herederos forzosos en línea recta anulará la institución de heredero, pero valdrán las mandas y mejoras en cuanto no sean inoficiosas.

Lo que significaba que la preterición anulaba en todo caso la institución de heredero, de suerte que el instituido perdía totalmente su porción de la herencia. Sin embargo, subsistían mandas y mejoras en tanto no perjudicaran las legítimas.

Si el preterido era el cónyuge viudo, la institución de heredero no se anulaba, conservando el preterido su derecho a la cuota vidual.

Premuriendo al testador los herederos forzosos preteridos, surtía efecto la institución. Sin perjuicio del derecho de representación que, dudosamente, asistiría a los descendientes de los herederos forzosos preteridos; bien en razón de su propio derecho al amparo del artículo 807 del Código Civil en otro caso, o, finalmente al amparo del derecho de sustitución. De suerte que, ni aún en el caso de suponer la preteri- 
ción una desheredación encubierta, perderian sus derechos los hijos o descendientes del preterido respecto a la legítima, no sólo por las razones apuntadas, sino, principalmente, por aplicación del artículo 857 del Código.

\section{B.- Redacción por Ley 11/1981.}

Distingue en la actualidad el artículo 814 entre preterición instencional y no intencional.

a.- Intencional. La preterición no perjudica la legítima, que debe recibir incluso con su porción de mejora, si el tercio de ella no estaba destinada específicamente a beneficiario concreto.

Planteado así el tema, se satisfará la legítima del preterido reduciendo la institución de herederos, y si aún así no se cubriese, seguirán el proceso reductor los legados, las mejoras y las demás disposiciones testamentarias.

b.- No intencional. Formula el artículo 814 las siguientes hipótesis y consecuentes efectos:

$1^{\circ}$.- Preterición de todos los legitimarios; supuesto que anulará las disposiciones testamentarias de contenido patrimonial.

$2^{\circ}$.- Preterición de sólo alguno o algunos de los legitimarios, se sigue la solución clásica de anulación de la institución de herederos, pero valdrán las mandas y mejoras en cuanto no resulten inoficiosas. Sin embargo, la institución de heredero en favor del cónyuge sólo se anulará en cuanto perjudique a las legítimas.

Cuestión interesante es la suscitada por el párrafo 5 del artículo 814 al establecer: "Los descendientes de otro descendiente que no hubiese sido preterido, representan a éste en la herencia del ascendiente y no se consideran preteridos".

Apuntaba Castán (7) que la tradición romanista desarrolló la doctrina de la representación considerándola aplicable, exclusivamente, a la sucesión intestada. Tesis seguida en nuestro derecho sucesorio, siquiera hasta la reforma del Código en 1981.

No obstante, hacía Castán referencia a la existencia de parte de la doctrina mantenedora de tesis ampliatorias, pronunciándose por la aplicación de la figura tanto a la sucesión testada como a la intestada, basándose en argumentos del tenor de algunos de los que recogemos:

a.- El derecho de representación es de aplicación tanto a la sucesión testada como a la legítima, por tratarse de un principio general de la sucesión familiar, como lo prueba el hecho de que el artículo 925 hable de que la representación tendrá lugar en la línea recta descendente siempre; es decir, en cualquier tipo de sucesión.

b.- La posibilidad de representar a persona viva en caso de desheredación, a que se refiere el artículo 929, es también buena demostración de que tal derecho se da en la sucesión testada, pues en la intestada no tiene sentido la desheredación.

De entre los argumentos contrarios a las opiniones expuestas, de taca Castán, sobre todos, los que distinguen entre la sustitución del artículo 744 y la represetación del 924, propia la primera de la sucesión testada, y de la intestada la segunda; citando, algunos valedores de esta postura como Royo Martínez, Lacruz-Sancho, 
Puig Brutau, De la Cámara Álvarez, etc.; y algunas sentencias propiciatorias de la misma, como las de 22 de junio de 1931; 7 de julio de 1950; 7 de junio de 1952; 5 de octubre de 1966, etc.

Para Lacruz-Sancho, por virtud se esta regla introducida en el artículo 814, el derecho de representación se produce en la sucesión testada en favor de quien la tendría igualmente si no hubiera testamento. (8).

También Torres Lana (9) se decanta por considerar la consagración por el precepto de un auténtico derecho de representación aplicable a la sucesión testamentaria, aunque cuida, escrupulosamente, de marcar las diferencias con la represetación regulada en los artículos 924 y siguientes del Código, estableciendo los caracteres diferenciales siguientes:

a.- Mientras en la representación no testamentaria el derecho de representación se extiende a los colaterales (artículos 925, 2, y 927), en la testamentaria se concreta a los descendientes en línea recta, en tanto únicamente se puede preterir a los legitimarios.

b.- El párrafo 5 del artículo 814 se limita al caso de la premoriencia del descendiente no preterido, pues su desheredación e indignidad se da en el artículo 766 que, a su vez, remite a los artículos 761 y 857.

c.- Las consecuencias patrimoniales derivadas del supuesto en estudio son asaz ambíguas y confusas, siendo las únicas hipótesis posibles dada la premoriencia, las siguientes: $1^{\mathrm{a}}$. Que el descendiente premuerto hubiera recibido una atribución patrimonial igual o mayor a su legítima material, supuesto en el que la representación actuaría normalmente, es decir, los herederos del premuerto ocuparían su lugar en la herencia. $2^{\mathrm{a}}$. Que el premuerto hubiere sido mencionado en el testamento pero no hubiera recibido nada, $o$, en todo caso, menos de lo que por legítima de correspondería; hipótesis en la que se conjugarían las reglas de la representación legitimaria deducidas de los artículos 925, 1, y 807,1. Los descendientes del premuerto adquiririan por representación la condición de legitimarios que les permitiría ejercitar la acción del artículo 815 en reclamación del complemento de su legítima estricta. $3^{\mathbf{2}}$. Que el descendiente hubiere sido omitido en el testamento, sin que tal omisión constituyere preterición por haber fallecido con anterioridad al otorgamiento del testamento. No cabe hablar de preterición en tanto no era preterible el hijo omitido, de ello que la omisión de sus descendientes deba resolverse por las reglas generales de representación en la legítima, pero no por la vía del párrafo 5 del artículo 814 .

Precisa Albadalejo el sentido de la preterición manifestando: "Tratándose de haber sido preterido, omitido o silenciado, es decir, de no habérsele dado nada ni inter vivos ni mortis causa, ni habérsele mencionado en el testamento aunque hubiere sido para desheredarlo (incluso injustamente), el legitimario, en defecto de que el testador haya dispuesto algo que respetando las legítimas, regule el caso distintamente... tiene derecho, como regla a que se reduzca primero la institución de heredero, y si aún no suprimida del todo, puede cubrirse la legítima, que se reduzcan a prorrata los legados, mejoras y demás disposiciones testamentarias, hasta lo necesario para cubrirlas.

Tras analizar los distintos supuestos y consecuencias de la llamada preterición 
no intencional, pone Albaladejo el acento en el párrafo 5 del artículo 814, puntualizando que tal precepto da solución al caso en el que sin él resultarían preteridos los descendientes ulteriores del causante que viniesen a ser legitimarios de éste en el puesto de un intermediario que llegase a faltar después del testamento y antes de la muerte del testador, como si viviendo sus hijos, el padre los instituye herederos y premuriéndole luego uno, con lo que pasan a ser legitimarios sus propios hijos en su puesto (nietos del testador), resultaría que éstos, no instituidos en el testamento del abuelo, pero siendo legitimarios de él cuando muere, habrían sido preteridos. Lo que se evita con el precepto en estudio, que les concede, como representantes de su padre, lo dejado en testamento a éste, evitándose así la preterición. (10).

\section{5.- Innovaciones en sede de mejoras.}

A.- Normativa anterior a 1981.

Solamente dos artículos han merecido la atención del legislador de 1981 en tema que nos ocupa, el 823 y el 831 ; ligeramente retocado el primero y más profundamente afectado el segundo.

Disponían, respectivamente, en su redacción de antaño:

Artículo 823: "El padre o la madre podrán disponer a favor de alguno o algunos de sus hijos o descendientes de una de las dos terceras partes destinadas a legítima. Esta porción se llama mejora".

Artículo 831: "No obstante lo dispuesto en el artículo anterior, podrá válidamene pactarse, en capitulaciones matrimoniales, que muriendo intestado uno de los cónyuges, pueda el viudo o viuda que no haya contraido nuevas nupcias, distribuir a su prudente arbitrio, los bienes del difunto y mejorar en ellos a los hijos comunes, sin perjuicio de las legítimas y de las mejoras hechas en vida por el finado".

B.- Modificaciones introducidas por la Ley 11/1981.

a.- Relativamente al artículo 823 , lo más destacable de la reforma es la referencia a hijos o descendientes por naturaleza o adopción.

b.- Más enjundia tiene la modificación del artículo 831, resumible en las notas siguientes:

$1^{\text {a. }}$ - Mientras en la redacción anterior la posibilidad de distribución de los bienes del causante por el cónyuge supérstite se hallaba en fución del fallecimiento abintestato de aquél, en la actual hace expresa referencia a ordenarse por testamento.

$2^{\mathrm{a}}$ - - Si antaño cabía mejorar a los hijos comunes "sin perjuicio de las legítimas y de las mejoras hechas en vida por el finado", subsiste hogaño tal posibilidad, expresada del siguiente modo: "sin perjuicio de las legítimas y de las mejoras y demás disposiciones del causante".

3‥- Se añade al artículo el párrafo que sigue: "Si no se hubiese señalado plazo, el viudo o viuda tendrá el de un año, contado desde la apertura de la sucesión, $o$, en su caso, desde la emancipación de los hijos comunes". 


\section{DE LA SUCESION INTESTADA}

A.- Normativa anterior a la Ley de 13 de mayo de 1981.

1.- Disposiciones generales:

Artículo 912: "La sucesión intestada tiene lugar: $1^{2}$. Cuando uno muere sin testamento, o con testamento nulo, o que haya perdido después su validez..."

Artículo 913: "A falta de herederos testamentarios, la Ley defiere la herencia, según las reglas que se expresarán, a los parientes legítimos y naturales del difunto, al viudo o viuda y al Estado".

2.- Del orden de suceder según la deversidad de líneas:

a.- Sección $2^{\mathrm{a}}$. De la línea recta ascendente:

Dedica el Código a este menester los artículos 935 a 942, inclusive pero, en rigor, pueden ser resumidos en la forma siguiente:

$1^{\text {ạ }}$. El padre y la madre, si existieren, herederán por partes iguales. Si sólo existe uno de ellos, sucederá al hijo en la totalidad de la herencia.

$2^{\mathrm{a}}$.- En defecto de padre y madre sucederán al causante los acendientes más próximos en grado.

3a - Existiendo varios de igual grado y de la misma línea, dividirán la herencia por cabezas. Siendo de igual grado pero pertenecientes a líneas diferentes, corresponderá la mitad de la herencia a los ascendientes paternos y la otra mitad a los maternos, haciéndose, en cada línea, la división por cabezas.

4 ${ }^{a}$ - Para el artículo 938: "Lo dispuesto en los dos artículos anteriores se entiende sin perjuicio de lo ordenado en los artículos 811 y 812 , que es aplicable a la sucesión intestada y a la testamentaria".

Especial interés tenía, en su anterior redacción, el artículo 935, disponiendo: "A falta de hijos y descendientes legítimos del difunto, le heredarán sus ascendientes, con exclusión de los colaterales".

El inciso final era imprescindible para zanjar la acalorada discusión en torno a si habrían de ser preferentes los colaterales o los ascendientes en los derechos sucesorios a la herencia intestada, 0 , según otra postura, si se debía llamar en estos casos conjuntamente a hermanos y ascendientes, dando preferencia a éstos sobre los demás colaterales.

b.- Sección 3a. De los hijos naturales reconocidos.

Artículo 939: "A falta de descendientes y ascendientes legítimos sucederán al difunto en el todo de la herencia los hijos naturales legalmente reconocidos y los legitimados por concesión Real".

Artículo 940: "Si con los hijos naturales o legitimados concurrieren descendientes de otro hijo natural o legitimado que hubiere fallecido, los primeros sucederán por derecho propio y los segundos por representación.

Artículo 941: "Los derechos concedidos al hijo natural o legitimado en los dos anteriores artículos, se transmitirán por su muerte a sus descendientes, quienes heredarán por derechos de representación a su abuelo difunto".

Artículo 942: "En el caso de quedar descendientes o ascendientes legítimos, los 
naturales y legitimados sólo percibirán de la herencia la porción que se les concede en los artículos 840 y $841 "$.

Artículo 943: "El hijo natural y legitimado no tiene derecho a suceder abintestato, a los hijos y parientes legítimos del padre o madre que les haya reconocido, ni ellos al hijo natural ni al legitimado".

Artículo 944: "Si el hijo natural reconocido o legitimado muere sin dejar posteridad legítima reconocida por él, le sucederá por entero el padre o madre que le reconoció y, si los dos le reconociesen y viven, le heredarán por partes iguales".

Artículo 945: "A falta de ascendientes naturales, heredarán al hijo natural y al legitimado sus hermanos naturales, según las reglas establecidas por los hermanos legítimos".

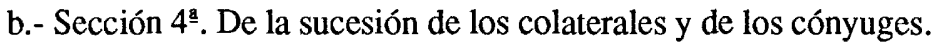

Artículo 946: "A falta de las personas comprendidas en las tres secciones que preceden (línea recta descendente; línea recta ascendente; hijos naturales reconocidos), heredarán los parientes colaterales y los cónyuges por el orden que se establece en los artículos siguientes".

No han sufrido alteración alguna los artículos 947 a 951 , ni los 954 y 955 . Fueron suprimidos por la Ley 11/1981, los artículos 952 y 953.

Aunque suprimido, como decimos, es curiosa la vicisitud sufrida por el artículo 952, hasta su definitiva desaparción, y así:

a.- Redacción originaria: "A falta de hermanos y sobrinos hijos de éstos, sean o no de doble vínculo, sucederá en todos los bienes del difunto el cónyuge sobreviviente que no estuviese separado por sentencia firme de divorcio".

b.- Redacción por Ley de 2 de abril de 1958: Es idéntica a la anterior, pero cambiando el inciso final "...que no estuviese separado por sentencia firme de divorcio", por "...que no estuviese separado por sentencia firme de separación personal".

c.- Supresión por la Ley de 13 de mayo de 1981, en cuenta entra en colisión frontal con ella.

B.-Estado de la cuestión tras la Ley 11/1981.

Sistemáticamente procede destacar:

a.- Modificación de la Sección $2^{\mathrm{a}}$ (de la línea recta ascendente), en lo siguiente:

$1^{\circ}$.- Eliminación de toda referencia a legitimidad del parentesco.

20.- Supresión, dada su superfluidad, del inciso final del artículo 935.

3․- Ordenación más sistemática de la materia.

b.- Inversión del orden en el epígrafe encabezador de la sección (antaño $4^{a}$ ), altamente significativo. En efecto, si antes era "De la sucesión de los colaterales y de los cónyuges", es ahora "De la sucesión del cónyuge y de los colaterales"..

c.- Regulación en la sección $3^{\text {a }}$ de la sucesión del cónyuge y de los colaterales, al desaparecer la regulación por aquélla de la sucesión intestada de los hijos naturales reconocidos.

d.- Inicio de la sección en el artículo 943, cuando la anterior partía del 946.

En definitiva, y relativamente a la sucesión abintestato del cónyuge viudo, dispone ahora el Código: 
Artículo 943: "A falta de las personas comprendidas en las dos secciones que preceden (línea recta descendente; línea recta ascendente), herederán el cóyuge y los parientes colaterales por el orden que se establece en los artículos siguientes".

Artículo 944: "En defecto de ascendientes y descendientes, y antes que los colaterales, sucederá en todos los bienes del difunto el cónyuge sobreviviente".

Artículo 945: "No tendrá lugar el llamamiento a que se refiere el artículo anterior si el cónyuge estuviera separado por sentencia firme, o separado de hecho por mutuo acuerdo que conste fehacientemente".

Evidentemente, de ocupar el décimo grado en el orden sucesorio abintestato hasta ponerse en cabeza, la progresión, el avance ha sido absolutamente radical. También es cierto que han debido transcurrir siglos y producirse mutaciones esenciales en la sociedad.

Más que nada a título de curiosidad, valdría la pena recordar una antañona polémica, resumiéndola en unas cuantas líneas.

¿Existe el susfructo vidual en la sucesión intestada? era el título con que Mucius Scaevola encabezaba un trabajo publicado en 1899 en la "Revista de los Tribunales".

Interrogación justificada, a la vista de la redacción originaria del artículo 953 del Código, que disponía: "En el caso de existir hermanos o hijos de hermanos, el viudo o viuda tendrá derecho a percibir en concurrencia con éstos, la parte de herencia en usufructo que le está señalada en el artículo 837". Ergo, y de la interpretación literal del artículo, se desprendía, inconcusa e inexorablemente, la inexistencia del derecho a la cuota vidual usufructuaria en la sucesión intestada, concurriendo con ascendientes y descendientes.

Obviamente, no todos los autores aceptaban la interpretación en su rigurosidad del artículo. Más he aquí que, hábilmente, vino a zanjar la cuestión la Ley de 24 de abril de 1958 con tan sólo añadir al controvertido artículo una simple frase: "la legítima que en todo caso corresponde al viudo o viuda en la sucesión intestada".

CONYUGE HEREDERO Y OBLIGACION DE RESERVAR.

Dos clases de reservas regula el Código, la lineal o troncal y la vidual o binupcial. A ambas nos referimos seguidamente.

A.- La reserva linal o troncal.

Por disposición del artículo 811 del Código Civil: "El ascendiente que heredare de su descendiente bienes que éste hubiese adquirido por título lucrativo de otro ascendiente, o de un hermano, se halla obligado a reservar los que hubiere adquirido por ministerio de la Ley en favor de los parientes que estén dentro del tércer grado y pertenezcan a la línea de donde los bienes proceden".

(Quizá convenga adelantar que nuestro propósito no es ahondar en el contenido del tan discutido y archiinterpretado precepto, sólo lo abordamos, de puntillas, en cuanto ha resultado afectado por la reforma llevada a cabo en sede de sucesiones por la Ley 11/1981).

Aclarado lo anterior, conviene destacar la opinión mantenida al respecto por distintos autores, y así: 
-Afirman Lacruz-Sancho: "A partir de la reforma de 1981, el cónyuge viudo, que tenía un lugar menos favorecido en el Código, pasa por delante de los hermanos del causante, lo cual no es muy justo cuando los bienes de éste son de procedencia familiar, y representa una contradicción con la reserva del artículo 811. ( $\mathrm{Si}$ el viudo hereda directamente nada tiene que reservar, mientras que si recibe los bienes del premuerto a través de un hijo que los heredó de aquél y se los transmite, se produce el supuesto de la reserva" (11).

En opinión de Torres Lana: "...la practicidad del precepto (811) va a verse notablemente reducida en la sucesión abintestato. En ésta, la nueva redacción del articulo 944 implica el sacrificio del principio de troncalidad a beneficio de una concepción nuclear de la familia...En consecuencia, el avance del cónyuge viudo en su posición sucesoria, a costa de los colaterales, disminuye ostensiblemente la frecuencia de la configuración del supuesto de hecho de la reserva troncal". (12).

Con fundamento en la tradición y en la esencia misma de la institución que estudiamos, escribe Albadalejo: "Después de la reforma del Código por la ley de 13 de mayo de 1981, la impresión parece que sería la de no haber duda de que actualmente la reserva del artículo 811 es aplicable cualquiera que sea la filiación matrimonial o no, de los parientes favorecidos de qué se trata... Sin embargo, no por discriminación de filiaciones, sino a base de las razones históricas por las que se introdujo la reserva y por la concepción de la troncalidad en que se funda, es también defendible la opinión de que, en principio, del beneficio del atículo 811 queda excluida aún hoy, la filiación no matrimonial..." (13).

Hace más de un siglo, escribía Alonso Martínez, en relación con los trabajos de la Comisión de Codificación, y concretamente en punto a reserva troncal: "Qué razones pudieron moverla (a la Comisión) a establecer la sucesión lineal, separándose del cauce secular?. Y seguía: "Lo diré en breves frases. Hay un caso, no del todo raro, que subleva el sentimiento de cuantos lo imaginan o lo ven: el hijo mayor de un magnate sucede a su padre en la mitad íntegra de pingües mayorazgos, tocando a sus hermanos un lote modestísimo en la división de la herencia paterna; aquél hijo se casa y fallece al poco tiempo dejando un tierno vástago; la viuda, todavía joven, contrae segundas bodas y tiene la desdicha de perder al hijo del primer matrimonio heredando toda su fortuna con exclusión de la madre y los hermanos de su primer marido. No hay para qué decir que, si hay descendientes del segundo matrimonio, a ellos se transmite en su día la herencia. Por donde resulta el irritante espectáculo de que los vástagos directos del magnate viven en la estrechez y tal vez en la miseria, mientras gozan de su rico patrimonio personas extrañas a su familia y que, por un orden natural, la son profundamente antipáticas. Esta hipótesis se puede realizar y se realiza, aunque por lo general en menor escala, antre propietarios, banqueros e industriales, labradores y comerciantes, sin necesidad de vinculaciones ni títulos nobiliarios". (14).

\section{B.- La reserva vidual.}

Tras la Ley de 13 de mayo de 1981, escasas modificaciones se advierten en los artículos 973 y 978 del Código; en el primero, la adición en el inciso final del párrafo segundo de la remisión -además de al artículo 857 , que ya hacía- al número $2^{\circ}$ del 
artículo 973. En lo que ser refiere al artículo 978, la alteración se reduce a excluir de su número $1^{\circ}$, la referencia a parafernales y dote.

Asimismo en esta línea de adecuación a las nuevas exigencias y realidades sociales, sufre alteración, en esta ocasión más amplia, el artículo 980 que en su redacción anterior a 1981 disponía: "La obligación de reservar impuesta en los anteriores artículos será aplicable al viudo o viuda que aunque no contraiga nuevo matrimonio, tenga en estado de viudez un hijo natural reconocido o declarado judicialmente como tal hijo. Dicha obligación surtirá efecto desde el día del nacimineto de éste.

Redacta la Ley de 1981 el artículo de referencia, de la forma que sigue: "La obligación de reservar impuesta en los anteriores artículos será también aplicable: $1^{\circ}$. Al viudo que durante el matrimonio haya tenido o en estado de vuidez tenga un hijo no matrimonial. $2^{\circ}$. Al viudo que adopte plenamente a otra persona. Se exceptúa el caso del consorte de quien descienden los que serían reservatarios. Dicha obligación de reservar surtirá efecto, respectivamente, desde el nacimiento o la dopción del hijo".

Evidentemente, si la reserva vidual se establece en favor de los hijos y descendientes del cóyuge fallecido, todos los bienes que hubiere recibido de éste o de los hijos de su finado matrimonio, por testamento, sucesión intestada, donación o cualquier otro título lucrativo, o de los parientes del difunto en consideración a éste, es claro que idéntico sentido subyace tanto en el hecho de contraer nuevas nupcias, como en el de tener un hijo en estado de viudez, o, constante matrimonio, de persona distinta del consorte, o en el de adoptar plenamente a una persona.

Evidencia confirmada por el propio artículo cuando, en el supuesto de adopción, no excluye de la reserva al adoptado, si éste fuere hijo del consorte de quien descienden los que serían reservatarios; y no lo excluye, precisamente, porque resulta que él mismo es reservatario.

Descuida el legislador cualquier clase de precisión al redactar los preceptos, así, en el caso que nos ocupa dice que la obligación de reservar surtirá efecto, respectivamente, desde el nacimiento o la adopción del hijo, ¿también desde el nacimiento del hijo no matrimonial habido en estado de casado?. La falta del mínimo de rigor que en ocasiones se aprecia en el legislador de nuestro tiempo conduce al terror pánico a los interpretes y comentaristas del derecho cuando a su conocimiento llega la inquietante noticia de la prevista, iniciada o proyectada corrección, modificación o elaboración de una Ley.

Puntualiza Torres Lana que la reforma no ha tenido en cuenta la concurrencia de dos elementos ajenos al origen y fundamento de la reserva, harto perturbadores. Son ellos: $1^{\circ}$. La existencia de hijos extramatrimoniales del cónyuge premuerto. $2^{\circ}$. La posibilidad de que las segundas nupcias hayan sido contraidas no por fallecimiento del cónyuge, sino como consecuencia de divorcio.

Con referencia al primer elemento señalado, la conclusión a obtener, interpretando en su literalidad el párrafo primero del artículo 108 del Código, sería la de la atribución del carácter de reservatarios única y exclusivamente a los hijos matrimoniales, empero la carga discriminatoria que ello parecería suponer. 
Más, por contra, sí podrían tener carácter de reservatarios los hijos extramatrimoniales de los hijos comunes del matrimonio.

La segunda de las hipótesis barajadas, es decir, que las nuevas nupcias hayan sido contraidas no por razón de fallecimiento sino por divorcio, parece no haber inquietado lo más mínimo al legislador de 1981, que no altera en la reforma ni una como sobre este punto. Despreocupación del legislador que coloca a Torres Lana en situación de plantear la disyuntiva siguiente: o el legislador de 1981 ha querido conservar los presupuestos del régimen anterior, manteniendo sólo para el viudo la obligación de reservar -lo que no le resulta lógico o no ha acometido su modificación por olvido o desconocimiento lamentables.

Ante tal shakesperiano dilema, se decanta Torres Lana -y probablemente acierte- por la segunda posibilidad apuntada. (15).

Opinan, también a este propósito Lacruz-Sancho: "...en la actualidad un evento que no pudo tener en cuenta el legislador de 1889 , el divorcio, disuelve igualmente el matrimonio, y por cierto sin dar lugar a la restitución de lo donado por un esposo al otro, y con mayor razón se impone en él la reserva si el divorciado vuelve a casarse o tiene otros hijos; el mismo conflicto de intereses debe tener la misma solución, que el legislador de 1889 no pudo formular expresamente". (16).

Se pregunta Albadalejo sobre la preponderancia de la reserva torncal a la de la binupcial, apuntando el decantamiento de la opinión más extendida en pro de aquélla, pero añadiendo: "De cualquier modo, a veces la equidad parecería pedir el triunfo de ésta". (17).

\section{De la colación y partición.}

\section{1.- Colación.}

Interesa de ella específicamente, el estudio del artículo 1045 en sus redacciones anterior y con ocasión de la Ley de 13 de mayo de 1981.

\section{A.- Redacción anterior a 1981.}

"No han de traerse a colación y partición las mismas cosas donadas o dadas en dote, sino el valor que tenían al tiempo de la donación o dote, sino el valor que tenían al tiempo de la donación o dote, aunque no se hubiese hecho entonces justiprecio. El aumento o deterioro posterior, y aun su pérdida total, causal o culpable, será a cargo y riesgo o beneficio del donatario".

B.- Redacción por Ley 11/1981.

"No han de traerse a colación y partición las mismas cosas donadas, sino su valor al tiempo en que se evalúen los bienes hereditarios. El aumento o deterioro físico posterior a la donación y aun se pérdida total, casual o culpalble, será a cargo y riesgo o beneficio del donatario".

El contejo de ambas redacciones resulta:

a.- Supresión de la referencia a la dote, régimen matrimonial económico suprimido del Código por la Ley de 1981.

b.- Relativamente al párrafo primero, en la redacción anterior al remitirse al valor de la cosa donada al tiempo de la donación -especialmente cuando hubiera 
transcurrido un largo periodo- constituía una más que posible discriminación que podría llegar a perjudicar gravemente los derechos de los restantes legitimarios; además de la dificultad de apreciación transcurridos, las más de las veces, varios años.

Más realista, la redacción actual permite una más adecuada apreciación y evita cualquier perjuicio, que, también hay que decirlo, pudiera en ocasiones repercutir en contra del donatario.

c.- En cuanto al segundo párrafo, la diferencia existente es la referencia concreta a deterioro físico del bien donado, siendo por lo demás, en ambas redacciones -en cuanto iguales- perfectamente ajustado a razón que revierta en beneficio del donatario el posible aumento del valor, en contrapartida del riesgo que ha de asumir de pérdida o deterioro.

\section{2.- Partición.}

Importante modificación es, sin duda, la efectuada por la Ley de 13 de mayo de 1981 en el artículo 1057 del Código.

Decía éste en su redacción anterior: "El testador pordrá encomendar por actos inter vivos o mortis causa para después de su muerte la simple facultad de hacer la partición a cualquier persona que no sea una de sus herederos. Lo dispuesto en este artículo y en el anterior se observará aunque entre los coherederos haya alguno menor de edad sujeto a tutela; pero el comisario deberá en este caso inventariar los bienes de la herencia, con citación de los coherederos, acreedores y legataios".

Dejándolos invariados en su redacción, incrusta la Ley 11/1981 entre los dos párrafos transcritos del artículo 1057, el siguiente: "No habiendo testamento, contador-partidor en él designado o vacante el cargo, el Juez, a petición de herederos y legararios que representen, al menos, el 50 por 100 del haber hereditario, y con citación de los demás interesados si su domicilio fuere conocido, podrá nombrar un contador-partidor dativo, según las reglas que la Ley de Enjuiciamiento Civil establece para la designación de peritos. La partición así realizada requerirá aprobación judicial, salvo confirmación expresa de todos lo herederos y legatarios".

Exige el párrafo en estudio una serie de reflexiones que podrían iniciarse por el desglose de cada uno de sus requisitos, y así:

$1^{\circ}$.- Inexistencia de testamento; aún existiendo que no se designe en él contador-partidor alguno; que, incluso habiéndose designado, el cargo estuviere vacante por no aceptación o imposibilidad del designado o por cualquier otra causa.

$2^{\mathrm{o}}$.- Que por un número de herederos y legatarios que representen, al menos, el 50 por 100 del haber hereditario, se solicite del Juez el nombramiento de contadorpartidor (llamado, para este caso, dativo).

3 .- Recibida por el Juez la petición, y previamente al nombramiento del solicitado contador-partidor, procederá a citar a los demás interesados si fuere conocido su domicilio.

¿Procederá, caso de no ser conocido el domicilio de alguno de los interesados, su citación, por edictos, como es práctica habitual? La contestación parece ser afir- 
mativa; la citación ha de llevarse a efecto, en cada caso, por el medio que la circunstancia determine.

4.- A tenor del artículo, no es menester más que la citación de los interesados no peticionarios, pues, comparezcan o no, el Juez procederá al nombramiento de contador-partidor, ateniéndose a las reglas que para la designación de peritos establece la Ley procesal civil.

A este propósito cabría apostillar: a) Tratándose de sucesiones la remisión podría entenderse a los artículos 1070, 1071 y 1073 de la Ley procesal. b) Sin embargo, del tenor del artículo 1057, la remisión no deja duda lo es a los artículos 610 y siguientes de dicha Ley. Pero, aceptada esa solución, tampoco es correcta la inteligencia de la aplicación de las reglas establecidas en meritados artículos, siendo de necesidad la exclusión de la mayoría de ellos por inaplicables, y sólo de utilidad los que encajen en las reflexiones que siguen:

a.- La mera petición dirigida al Juez faculta a éste, a tenor del artículo en cuestión, para designar contador-partidor a la persona que tenga por conveniente, sin necesidad de previa comparecencia ni intervención de las partes. Postura sostenible pero harto discutible, haciendo entrar en colisión el artículo 1057 y los relativos a comparecencia de las partes para insaculación de peritos.

b.- No parece quepa oposición al nombramiento del contador-partidor, por los no peticionarios citados, en tanto discutible la necesidad de la comparecencia prevista en el artículo 614 de la Ley procesal. Si bien podrán hacer uso posterior de su derecho.

c.- Por aplicación analógica del artículo 1070 -y pues que con relación a los peritos establece la Ley que estén en posesión de tales en la ciencia o arte a que pertenezca el punto sobre el que deben dictaminar- la persona designado por el Juez contador-partidor habrá de ser Letrado.

5.- Aceptado el cargo, el contador designado procederá a la redacción del cuaderno particional, que deberá ser aprobado por el Juez salvo confirmación expresa de todos los herederos y legatarios.

No resultaría aventurado opinar que el párrafo estudiado del artículo $1057 \mathrm{se}$ introdujo por el legislador como una posibilidad más de evitar el recurso al artículo 1059 por algún heredero.

De esta forma, prevista normativamente la partición hecha por el propio testador; la realizada por el contador-partidor designado por aquél; y la que directamente llevaran a efecto los propios herederos, solo quedaba un resquicio a la temeridad de algún heredero intransigente que, oponiendose a la opinión uniforme de los restantes, podía, sin embargo, entablar el juicio de testamentaría. Y este resquicio, este portillo, es el que pretende ocluir el párrafo comentado; introduciendo, además, una escrupulosa matización en respuesta al caso concreto, así: inexigencia de aprobación judicial cuando exista conformidad expresa de todos los herederos y legatarios; necesidad en otro caso, de dicha aprobación.

Escribe Torres Lana: "La intervención judicial supone sólo un control de la legalidad e imparcialidad del proceso que se inicia con el nombramiento del conta- 
dor-partidor y culmina con la adjudicación." y añade "...el contenido del cargo, en cuanto a sus funciones, deberes y plazo para desempeñarlo, parece ser idéntico al del contador-partidor testamentario". (18).

Para Lacruz-Sancho: "Será Juez competente para el nombramiento de contador dativo el que lo sea para la testamentaría. La arbitración no tiene valor definitivo, sino que requiere aprobación judicial: el artículo 1057 no limita los extremos a que puede extenderse, a tal efecto, el examen del Juez, quien, por tanto, podrá negar su refrendo, no sólo por falta de aplicación de alguna norma legal o por defectos formales, sino también por lesión de un partícipe, o inexacta valoración de un bien, etc. En cualquier caso tal aprobación no convierte a la partición en judicial". (19).

En opinión de Albadalejo: "Con este nuevo procedimiento no hay necesidad de promover alguno de los engorrosos juicios universales... para llegar en definitiva a una partición consentida por otros, ni de plantear un largo y costoso juicio declarativo ordinario para, si alguno se opone a tal partición, conseguir un reparto de los bienes hereditarios que vincule a los conformes y a los disconformes". (20).

Procede añadir a lo referido:

A.- A tenor del párrafo segundo del artículo 841, también el contadro-partidor dativo goza de la facultad de adjudicar todos los bienes herecitarios o parte de ellos a uno de los herederos, mandando se pague en matálico la porción correspondiente a los restantes herederos.

B.- Si bien no se habla de remuneración al contador-partidor dativo, prosperando la tesis de que éste haya de ser Abogado, es innegable la obligatoriedad de satisfacción de sus honorarios.

C.- Empero referidos a contador-partidor nombado por el testador, son de aplicación al dativo las sentencias del Tribunal Supremo siguiendo la doctrina marcada por la de 12 de diciembre de 1927, que establecía: "La partición hereditaria formalizada por el comisario nombrado causa estado y no puede ser impugnada en vía gubernativa y ha de producir, mientras los Tribunales no declaren lo contrario, los efectos y consecuencias que lógicamente se deriven de los términos en que se halle redactada, pero los herederos que se crean perjudicados por la interpretación dada a las cláusulas testamentarias, por la valoración del caudal relicto, o por cualquier otra circunstancia, pueden atacar la partición o solicitar su rescisión".

De la modificación del artículo 1060.

También objeto de la atención del legislador de 1981, disponía en su anterior redacción:

"Cuando los menores de edad estén sometidos a la patria potestad y representados en la partición por el padre o, en su caso, por la madre, no será necesario la intervención no la aprobación judicial".

Manifiesta en su redacción actual:

"Cuando los menores o incapacitados estén legalmente representados en la partición, no será necesaria la intervención ni la aprobación judicial".

En relación con la anterior redacción, es de destacar de la nueva:

$1^{\circ}$.- Referencia no sólo a menores sino también a incapacitados. 
$2^{\circ}$.- La representación legal, caso de patria potestad, corresponde en la actualidad, y conjuntamente, al padre y a la madre. Los incapacitados pueden estar sujetos a patria potestad prorrogada.

3o.- Menores e incapacitados pueden estar sujetos a tutela, siendo entonces el tutor su representante legal. (Tras la reforma de las instituciones tutelares en 1983, conviene reseñar lo siguiente: Artículo 271: "El tutor necesitará autorización judicial: ...4ํ.- Para realizar la partición de la herencia o la división de una cosa común, las cuales, una vez practicadas, requerirán, además, la aprobación judicial..." y el artículo 272: "También necesitará el tutor autorización judicial: 1ํ.- Para aceptar sin beneficio de inventario cualquier herencia o para repudiar ésta o las liberalidades...").

Se preguntaba Manresa: "¿Cuándo será necesaria y cuando no la aprobación judicial de las particiones de herencia, según el estado actual de nuestro derecho?, y continuaba:

Aun mediando menores o incapacitados o ausentes, no es exigible dicha aprobación en los casos siguientes:

$1^{\circ}$.- Cuando la partición hubiese sido practicada por el mismo testador.

$2^{\circ}$.- Cuando se haya hecho por persona a quien el testador hubiese encomendado esta facultad, siempre que no sea uno de los herederos e inventariando los bienes, con citación de dichos herederos, acreedores y legatarios.

$3^{\circ}$.- Cuando los menores de edad estén sometidos a la patria potestad y representados en la partición por su padre o su madre, siempre que éstos no tengan en la herencia interés en oposición con los del hijo menor.

$4^{\circ}$.- En las particiones de herencia practicadas antes de la Ley de Enjuiciamiento Civil de 1855.

5o.- Cuando tratándose de herederos voluntarios, el testador hubiera dispuesto que se hiciesen las particiones sin el requisito de la aprobación judicial.

Sigue Manresa: habría que añadir otro caso, el de tratarse de personas sujetas a tutela, por estimarse que en tal caso correspondería la aprobación al consejo de familia. Pero aún en este caso, tal aprobación debería sustituirse por la judicial cuando todos los individuos del consejo o la mayoría de ellos resultasen incompatibles..." (21).

En rigor el problema nace de la colisión entre el artículo 1060 del Código Civil y el 1049 de la Ley de Enjuiciamiento Civil, que establece: "Las liquidaciones y particiones de herencia hechas extrajudicialmente, aunque lo hayan sido por contadores nombrados por el testador, deberán presentarse a la aprobación judicial siempre que tenga interés en ellas como heredero o legarario de parte alícuota algún menor incapacitado o ausente cuyo paradero se ignore". Pero como el propio Manresa señala, el artículo 1049 de la Ley procesal se halla modificado en el Código por los artículos 1057 y 1060. (22). 


\section{ACLARACION FINAL}

Obviamente habrá advertido el lector la omisión de referencia a algunos de los artículos también afectados por la Ley de 13 de mayo de 1981, como, por ejemplo, los números $741,761,692,962,855,857$, etc., la razón de ello respondió al entendimiento de que las modificaciones introducidas consistieron en meros retoques adecuatorios en la mayoría de los casos, o supresión de algún matiz que, en general, no afectaba esencialmente a su contenido.

Y así, en ello como en cualquier otro punto que hubiera sido omitido en este trabajo, vino también a incidir el compromiso de enviarlo para su publicación en la Revista Anales de la Facultad de Derecho de esta Universidad, que, en consideración a mi persona que desde aquí agradezco sinceramente, amplió en algunos días el término de entrega de los originales.

\section{NOTAS BIBLIOGRAFICAS}

(1).- Volterra. (Anotado y puesto al día por Daza Martínez.- Pg. 779.- Madrid, 1988.

(2).- Edición facsimil del B.O.E.

(3).- Lacruz Berdejo-Sancho Rebullida.- Elementos de Derecho Civil. V.- Derecho de Sucesiones.- Barcelona, 1982. Pg. 561.

(4).- Díez-Picazo-Gullón Ballesteros.- Sistema de Derecho Civil. V.- Derecho de familia y sucesiones.- Pg. 641.- Madrid, 1982.

(5).- Lacruz-Sancho.- Ibid.

(6).- Torres Lana.- "Reforma de familia y sucesión mortis causa". en Documentación Jurídica.- Núms. 33 a 36. Enero-Diciembre. V.I., 1982.

(7).- Cf. Castán Tobeñas.- Derecho Civil español común y foral.- T. 6․- V. 3ำ .- Madrid, 1971.

(8).- Cf. Lacruz-Sancho.- Op. Cit. Pg. 562.

(9).- Cf. Torres Lana.- Op. Cit, Pgs. 335-336.

(10).- Df.- albaladejo.- Curso de Derecho Civil. V.- Derecho de Sucesiones.- Barcelona, 1982.- Pgs. 385 a 387 .-

(11).- Lacruz-Sancho.- Op. Cit. Pgs. 561-2.

(12).- Cf.- Torres Lana.- Op. Cit. Pg. 339.

(13).- Albaladejo.- Op. Cit. Pg. 398.

(14).- Alonso Marínez.- El Código Civil en sus relaciones con las legislaciones forales.Editorial Plus-Ultra. Madrid, 1949. Pgs. 185-186.

(15).- Cf. Torres Lana- Op. Cit. Pg. 339.

(16).- Lacruz-Sancho.- Op. Cit.- Pg. 572.

(17).- Albaladejo.- Op. Cit.- Pg. 397.

(18).- Torres Lana.- Op. Cit.- Pgs. 333-334

(19).- Lacruz-Sancho.- Op. Cit.- Pg. 147.

(20).- Albaladejo.- Op. Cit.- Edición, 1991.- Pg. 162.

(21).- Manresa Navarro.- Comentarios al Código Civil.- T.VII. Pgs. 739-740.

(22).- Manresa.- Op. Cit.- Pg. 735. 


\title{
LOS ENCLAVES PROVINCIALES EL CASO DEL CONDADO DE TREVIÑO
}

\author{
JOSÉ JUAN SERVER GALLEGO
}

\author{
SUMARIO \\ I. CONSIDERACIONES PREVIAS. \\ II. CLASIFICACION DE LOS ENCLAVES PROVINCIALES. \\ III. LA PROBLEMATICA DE LOS ENCLAVES. \\ IV. LAS VIAS LEGALES DE DESAPARICION DE ENCLAVES. \\ V. EL CASO DEL CONDADO DE TREVIÑO.
}

\section{CONSIDERACIONES PREVIAS.}

El presente trabajo gira en torno a una realidad poco conocida y que suele pasar totalmente desapercibida: los enclaves provinciales. El enclave provincial es la porción del territorio de una provincia separada de la misma y totalmente rodeada por el territorio de otra u otras provincias. El único enclave algo más conocido por el público en general es el Condado de Treviño, sin duda debido a la extensión de su territorio y al hecho de que, a diferencia de los demás, suele figurar en todos los mapas que incluyen la división provincial. Sin embargo, los enclaves son una realidad bastante extendida y, como luego veremos, pueden conllevar en ocasiones cierta problemática, circunstancia que aconseja prestarles alguna atención. El caso concreto del Condado de Treviño ha llegado incluso a ser objeto de una sentencia del Tribunal Constitucional (1), cuyo análisis es el origen y el objeto principal de este breve estudio.

Los enclaves son particularmente abundantes en la zona centro de la mitad septentrional de España y, concretamente, entre las Comunidades de Castilla-León, País Vasco y Cantabria, siendo muy escasos en la mitad meridional. Su origen, en opinión de Gómez Fernández (2), se sitúa en la época de la Reconquista y su evolución histórica corre paralela a las vicisitudes de la división territorial de nuestro país. De ahí que, seguidamente, hagamos un breve repaso de la historia de dicha división territorial, siguiendo en este punto a Martín-Retortillo (3).

Considera el citado autor que a lo largo del Antiguo Régimen no pudo alcanzarse una ordenación territorial única y con validez general y que el sistema de Intendencias del siglo XVIII no canceló globalmente la heterogénea multiplicidad de circunscripciones territoriales existentes en España. El primer intento de modificación global del mapa político-administrativo de Carlos III fue la división prefectoral establecida por José I mediante Decreto de 17 de abril de 1810, división que no se inspiraba en criterios históricos y que, por tanto, no contemplaba la existencia de enclaves. Por otra parte, en ejecución de lo dispuesto por la Constitución de Cádiz, el Decreto LIX de 22 de enero de 1822 de las Cortes extraordinarias, sancionó una 
división provincial, de carácter igualmente ahistórico, que suprimió radicalmente los enclaves. Pero el fin del Trienio Liberal supuso el retorno a las divisiones anteriores.

Posteriormente, por Decreto de 30 de noviembre de 1833, Javier de Burgos estableció la división provincial que ha perdurado hasta nuestros días. MartínRetortillo, siguiendo la opinión de Guaita, considera que este Decreto sí respetó al máximo las divisiones históricas, asumiendo en ocasiones límites que ya entonces tenían más de dos siglos de vigencia. La división provincial de Javier de Burgos sí respetó los tradicionales enclaves, que han perdurado así hasta nuestros días, incorporándose con sus respectivas provincias al actual mapa autonómico.

Conviene aclarar que los enclaves provinciales no constituyen el único tipo de enclave territorial existente. También existen enclaves municipales, entendiendo por enclave municipal la porción de un término municipal separada del mismo y totalmente rodeada por otro u otros términos municipales (4). Pero, como señala Larumbe Biurrun (5), dada su escasa problemática y su excepcionalidad, no requieren que se les preste mayor atención.

También existe un caso de lo que podríamos denominar "enclave internacional". Se trata de Llivia, municipio de la provincia de Gerona, situado al NE. de Puigcerdá, en la Cerdaña y enclavado en territorio francés, a dos Kilómetros de la frontera con España. Su origen data del tratado de los Pirineos de 7 de noviembre de 1659. Obviamente, este caso es sustancialmente distinto de los anteriores, habida cuenta de que aquí ya no se trata de una simple cuestión de límites provinciales, sino que entran en juego cuestiones tales como las fronteras internacionales y el ámbito de soberanía de los Estados, además de que su problemática también es distinta.

\section{CLASIFICACION DE LOS ENCLAVES PROVINCIALES.}

Como ya hemos dicho al principio, podemos entender por enclave provincial la porción del territorio de una provincia separada de la misma y totalmente rodeada por el territorio de otra u otras provincias.

A efectos meramente expositivos, y dada su distinta problemática, conviene distinguir dos tipos básicos de enclaves provinciales.

1.- Enclaves comunitarios: se trata del caso en que el enclave se encuentra separado del territorio de la Comunidad Autónoma a la que pertenece y totalmente rodeado por el territorio de otra u otras Comunidades Autónomas. Se subdividen en:

A) Intercomunitarios: rodeados por el territorio de más de una Comunidad Autónoma. Es el caso del Rincón de Ademuz, perteneciente a la provincia de Valencia y, por ende, a la Comunidad Valenciana, y situado entre las Comunidades de Castilla-La Mancha y Aragón (6). La causa de este singular enclave se remonta a la Reconquista, durante la cual Jaime I respetó los tratados con Castilla y Aragón por los cuales se consideraba a Santa Cruz de Moya, municipio castellano que separa al Rincón de Ademuz del territorio Valenciano, de gran importancia estratégica y geográfica, por ser camino obligatorio entre Aragón y Castilla. Ello determinó para el futuro el que el Rincón no esté unido al resto de su Comunidad (7). 
B) Enclaves intracomunitarios: rodeados por el territorio de una sóla Comunidad Autónoma. Es el caso de Villaverde de Trucios, perteneciente a Cantabria y encavado en Vizcaya; el Condado de Treviño, perteneciente a Burgos y enclavado en Alava; Petilla de Aragón, perteneciente a Navarra y enclavado en Zaragoza; Cezura y Lastrilla, pertenecientes a Palencia y enclavadas en Cantabria; Sajuela y Ternero, pertenecientes a Burgos y enclavados en La Rioja.

2.- Enclaves no comunitarios o provinciales en sentido estricto: se trata de aquellos enclaves que, aún estando separados de la provincia a la que pertenecen, no lo están totalmente de su Comunidad Autónoma. Se subdividen en:

A) Interprovinciales: rodeados por el territorio de más de una provincia. Es el caso de Berzosilla, perteneciente a Palencia y enclavada entre Cantabria y Burgos; Orduña, perteneciente a Vizcaya y enclavada entre Alava y Burgos; Quintanilla del Molar y Roales, pertenecientes a Valladolid y enclavados entre León y Zamora; Anchuras, perteneciente a Ciudad Real y enclavada entre Toledo y Badajoz.

B) Intraprovinciales: totalmente rodeados por el territorio de una sóla provincia. Es el caso de Villodrigo, perteneciente a Palencia y enclavado en Burgos.

\section{LA PROBLEMATICA DE LOS ENCLAVES.}

El único fundamento que puede tener hoy en día el mantenimiento de los enclaves es el respeto a la tradición histórica, que en algún caso podrá, además, estar acompañada de la voluntad favorable de los habitantes de dichos enclaves a mantener su statu quo. Por otro lado, dicho mantenimiento no deja de plantear dificultades. En efecto, al margen de las comprensibles "aspiraciones anexionistas" que puedan surgir en las provincias o Comunidades Autónomas en las que estén enclavados estos territorios, no puede ignorarse la existencia de otros problemas que sí son dignos de tener en consideración. Estos problemas son, básicamente, y dejando a un lado los casos puntuales, de dos órdenes:

1.- En primer lugar, la dependencia administrativa del enclave de una provincia de la que se encuentra totalmente separado supone ir en contra del principio de máxima proximidad de la Administración al administrado y puede ocasionar a sus habitantes la necesidad de desplazarse, para realizar determinados trámites, a poblaciones muy distantes de su lugar de residencia y distintas de aquéllas a las que, de hecho, se encuentran geográficamente vinculados y donde realizan la mayor parte de los actos de la vida diaria, tales como su actividad profesional, compras u ocio. Ello puede ocasionar el deseo, por parte de dichos habitantes, de pasar a depender de la provincia en la que están enclavados. Esto es lo que ha sucedido, por ejemplo, en el Condado de Treviño.

2.- En el caso de los enclaves intracomunitarios -es decir, aquellos que, estando separados de la Comunidad Autónoma a la que pertenecen, están rodeados por el territorio de una sóla Comunidad Autónoma- puede darse un segundo orden de problemas; se trata, concretamente, del caso en que una Comunidad pretenda llevar a cabo determinadas actuaciones en un área en el que se encuentre comprendido un enclave de otra Comunidad. Los ejemplos son múltiples, pero baste citar aquí algunos de ellos: construcción de carreteras o ferrocarriles cuyo itinerario se desarrolle 
íntegramente en el territorio de la Comunidad, ordenación del transporte desarrollado por estos medios o por cable, construcción de canales y regadíos, ordenación del turismo, vías pecuarias, ordenación del territorio y urbanismo. Particular interés tienen, a este respecto, las medidas de protección del medio ambiente, cuya eficacia requiere frecuentemente actuaciones homogéneas en áreas extensas.

En todos estos casos, la actuación prevista puede verse seriamente dificultada, cuando no imposibilitada, por la presencia de una porción aislada de territorio en la que la Comunidad no puede actuar, planteándose en todo caso la necesidad de llegar a acuerdos con otra Comunidad o, en su caso, con el Estado.

Ciertamente, este segundo orden de problemas no será frecuente en la práctica, habida cuenta del reducido tamaño que tienen la mayoría de los enclaves y del hecho de que suelen estar muy próximos al límite de la Comunidad a la que pertenecen. Pero, aunque sea de forma esporádica, pueden darse en algún caso. Prueba de ello es el conflicto positivo de competencias 616/87 promovido por el Consejo de Gobiemo de la Diputación Regional de Cantabria frente al Gobierno Vasco en relación con diferentes actuaciones que se imputan a éste último dentro del territorio de Villaverde de Trucios.

\section{LAS VIAS LEGALES DE DESAPARICION DE ENCLAVES.}

Analizada la problemática que conlleva el mantenimiento de los enclaves, parece oportuno estudiar ahora las posibles vías de supresión de los mismos.

La desaparición de los enclaves, con la nueva adscripción provincial de los respectivos territorios, plantea problemas diferentes según las circunstancias del caso concreto. Para empezar, está el problema de determinar la provincia a la cual incorporar el enclave en el caso de que éste sea interprovincial; en tal caso, un posible criterio a seguir es el de la voluntad de los habitantes del enclave.

En cuanto a los aspectos estrictamente jurídicos del proceso, analizaremos por separado el supuesto de los enclaves comunitarios y el de los no comunitarios o provinciales en sentido estricto. Previamente hay que señalar que, con carácter general, el artículo 141.1 de la Constitución establece que "cualquier alteración de los límites provinciales habrá de ser aprobada por las Cortes Generales mediante ley orgánica".

1.- En el caso de los enclaves no comunitarios o provinciales en sentido estricto, su desaparición como tales enclaves se regirá por las normas que regulan el cambio de límites provinciales; concretamente por el artículo 25.2 del Real Decreto Legislativo 781/1986 (8) que, según su Disposición Final séptima, letra a), tiene carácter de legislación básica. Este precepto se limita a repetir que cualquier alteración de los límites provinciales exigirá ley orgánica, sin establecer expresamente ningún otro trámite. Lo normal, en el caso que nos ocupa, será que el proceso se ponga en marcha por acuerdo adoptado por el Ayuntamiento o Ayuntamientos del enclave en cuestión. En cualquier caso será conveniente convocar un referéndum entre los habitantes del mismo para que éstos puedan manifestar democráticamente su parecer respecto al cambio de adscripción provincial.

En cuanto a la regulación de dicho referéndum, es necesario distinguir el supuesto de que sea celebrado por el propio Ayuntamiento o Ayuntamientos interesados, del supuesto de que sea celebrado por el Estado. 
En el primer caso, no será aplicable la Ley Orgánica Reguladora de las Distintas Modalidades de Referéndum (9), ya que su Disposición Adicional establece que las normas de dicha ley "...no alcanzan en su regulación a las consultas populares que puedan celebrarse por los Ayuntamientos, relativas a asuntos relevantes de índole municipal, en sus respectivos territorios, de acuerdo con la legislación del Régimen Local, y a salvo, en todo caso, la competencia exclusiva del Estado para su autorización". Sí será, en cambio, aplicable el artículo 71 de la Ley Reguladora de las Bases del Régimen Local, de modo que será necesario el previo acuerdo del Pleno municipal por mayoría absoluta y la autorización del Gobierno de la Nación, además del cumplimiento de los demás requisitos que, en su caso, establezca la legislación de las Comunidades Autónomas con competencias en la materia.

En el caso de que la consulta popular sea celebrada por el Estado, habrá que entender aplicables las normas de la ya mencionada Ley Orgánica Reguladora de las Distintas Modalidades de Referéndum. En este caso no jugará, obviamente, lo dispuesto en el artículo 71 de la Ley Reguladora de las Bases del Régimen Local.

2.- En el caso de los enclaves comunitarios, la desaparición del enclave conlleva una alteración en el ámbito territorial de dos Comunidades Autónomas. Ello nos obliga a prestar atención al régimen que regula dichas alteraciones y, por consiguiente, a lo que establezcan los respectivos Estatutos de Autonomía.

El artículo 147.2.b de la Constitución prescribe, como contenido necesario de los Estatutos de las Comunidades Autónomas, la "delimitación de su territorio". Ello ha dado lugar a normas estatutarias de contenido diverso. Como aclara el Tribunal Constitucional, en la ya mencionada Sentencia 99/86, fundamentos 4 y 5 , "en unos casos, el territorio de la Comunidad Autónoma es definido por relación al de los municipios integrados en la provincia o provincias que contribuyen a crear el nuevo Ente autónomo y acceden así a su autogobierno. ...Puede así decirse que en este modo de delimitar el territorio autonómico se actúa mediante normas cuyo objeto no es, en rigor, el territorio mismo, sino el ámbito espacial de aplicación de los actos y disposiciones jurídicas pertenecientes al subsistema normativo de cada Comunidad Autónoma". En estos casos, tanto la inclusión como la exclusión de municipios en las provincias que integran la Comunidad Autónoma y, por tanto, la incorporación o segregación de enclaves, no supondrán reforma del Estatuto de Autonomía y se regirán por lo ya expuesto para el caso de que no haya cambio de Comunidad Autónoma. En sentido contrario se pronuncia Rivero Ysern (10), pues considera necesario acudir, en todo caso, al procedimiento de reforma estatutaria.

Como sigue diciendo el Tribunal, "En otros casos, lo normado no es ya tan sólo el ámbito de aplicabilidad de las disposiciones autonómicas y de los actos de sus órganos, sino el territorio mismo como espacio natural. Se introduce así en el Estatuto una específica garantía territorial mediante la cual los límites geográficos con los que se constituyó al nacer la Comunidad Autónoma quedan consagrados en su norma institucional básica. Así, el Estatuto de Autonomía del País Vasco, con expresión análoga a las que se encuentra en otros Estatutos, se refiere, en su artículo 2.2, a los 'actuales límites' de los Territorios Históricos que integran esta 
Comunidad. Esta segunda forma de delimitación del territorio impide toda alteración del mismo que no se realice mediante el procedimiento establecido para la revisión del Estatuto...". Así pues, si una o ambas Comunidades Autónomas se encuentran en este segundo caso, además de los trámites anteriormente expuestos para la alteración de los límites provinciales, habrá que proceder a la reforma del Estatuto o Estatutos correspondientes. En este caso, la ley orgánica de reforma del Estatuto puede servir, al mismo tiempo, para satisfacer la exigencia del artículo 141.1 de la Constitución, opinión también sostenida por Luis María Diez-Picazo (11).

Ahora bien; puede ocurrir que los Estatutos de Autonomía establezcan procedimientos especiales de segregación o agregación de enclaves. En tal caso habrá que estar, obviamente, a lo establecido en dichos Estatutos. Sólo los Estatutos del País Vasco y Aragón (12) establecen procedimientos de incorporación de enclaves a su territorio y sólo el de Castilla-León establece un procedimiento de segregación.

\section{EL CASO DEL CONDADO DE TREVIÑO.}

El Condado de Treviño es un enclave intracomunitario situado al sur de la provincia de Alava y perteneciente a la de Burgos. Está integrado por los municipios de La Puebla de Arganzón y Treviño. Su extensión es mucho mayor que la normal de los enclaves y sólo pueden compararse a ella la del Rincón de Ademuz (Valencia) y la de Anchuras (Ciudad Real).

En cuanto al origen histórico de este enclave, el Condado de Treviño, región conocida en el medioevo como Ibida, lleva vida independiente de Alava desde hace, al menos, ocho siglos. En efecto, tras una guerra por el dominio de las tierras alavesas, Alfonso VIII de Castilla y Sancho el Sabio de Navarra firman la transacción de 1179, por la que Castilla cede a Navarra el territorio alavés, excepto Castellar y Treviño. Más tarde, Castilla fue invadida por León y Navarra, pero Alfonso VIII recuperó los territorios perdidos. Después del año 1200, en que Alfonso VIII conquista Alava e Ibida, completando el dominio de este último territorio con Treviño y Portilla mediante cambio, no se halla en las fuentes mención expresa de dependencia de Ibida respecto a Alava.

En 1332, la Cofradía de Alava decide someterse al señorío del Rey de Castilla, Alfonso XI; en este momento, el Condado de Treviño no formaba parte de dicha Cofradía. Ni siquiera hay noticia documental de que perteneciese en algún momento a la misma.

En 1366, Enrique II le da a su Adelantado mayor en Castilla, Don Pedro Manrique, la villa de Treviño con sus aldeas, instituyendo mayorazgo de varón. Hacia 1453 fue hecho Conde de Treviño don Diego Gómez Manrique. En 1482, los Reyes Católicos facultan a Don Pedro Manrique, Conde de Treviño, para incorporar Nájera a su antiguo mayorazgo, obteniendo, finalmente, el título de Duque de Nájera. En 1593, Felipe II concede al Duque de Nájera, a petición de éste, que concurra en la persona de su hijo mayor el título de Conde de Treviño, que afirmaba seguir conservando. 
En opinión de Gómez Fernández (13), el hecho de que los reyes de Castilla den su villa, con sus aldeas y términos, pone de manifiesto que aquellas tierras eran realengo y, por tanto, diferentes y separadas de Alava, que tenía un régimen especial hasta su sumisión al señorío real. Entre las villas realengas de aquella región estaban Vitoria, Treviño y Arganzón. Ello corrobora que el Condado de Treviño no tenia vida común con la Cofradía de Alava. Concluye el citado autor diciendo que la razón última de la adscripción de Treviño a Burgos radica, precisamente, en el hecho de haber sido realengo.

Finalmente, cabe señalar que el señorío concedido por el Rey de Castilla en el siglo XIV seguía vigente a principios del siglo XIX y que en el Diccionario Histórico-Geográfico de 1802 no figura el Condado como parte de Alava. Así las cosas, la división provincial de 1833 dio al mencionado Condado la configuración geográfica que tiene hoy día.

Como puede verse, la adscripción del Condado de Treviño a Castilla-León no carece de fundamento histórico. Sin embargo, está extendida la opinión de que resulta manifiesta la artificialidad y anacronismo que supone mantener esta situación, como lo pone de manifiesto el hecho de que los vecinos del Condado realicen su vida cotidiana en Vitoria. Los inconvenientes que viene originándoles esta anómala situación, básicamente derivados de hallarse a un centenar de kilómetros de Burgos y a una quincena de Vitoria, han dado lugar desde 1919 a tradicionales intentos de incorporación a Alava. Sin embargo, pese a lo anómalo de su situación y a las constantes muestras de voluntad incorporacionista por parte de los vecinos del Condado de Treviño, éste se ha mantenido como un enclave perteneciente a la provincia de Burgos, sin que ocurra lo mismo en el terreno eclesiástico, ya que desde el 15 de febrero de 1951 está incorporado a Alava.

El tema de los enclaves ha sido objeto de atención en los sucesivos Estatutos de Autonomía del País Vasco. El Proyecto de Estatuto de 1931 establecía un procedimiento basado en la simple solicitud de la mayoría de los habitantes del enclave. El artículo 8 del Proyecto de Estatuto de 1933 establecía tres requisitos: solicitud del Ayuntamiento o mayoría de los Ayuntamientos, aprobación del Parlamento Vasco y de las Cortes Generales, previa audiencia de la provincia o región a cuya jurisdicción perteneciera el enclave. El vigente Estatuto de Autonomía del País Vasco (14) ha regulado en su artículo 8, claramente inspirado en el del Proyecto de 1933, un procedimiento de incorporación de enclaves intracomunitarios situados en su territorio. Dicho artículo es del siguiente tenor literal: "Podrán agregarse a la Comunidad Autónoma de País Vasco otros territorios o municipios que estuvieran enclavados en su totalidad dentro del territorio de la misma, mediante el cumplimiento de los requisitos siguientes:

a) Que soliciten la incorporación el Ayuntamiento o la mayoría de los Ayuntamientos interesados, y que se oiga a la Comunidad o provincia a la que pertenezcan los territorios o municipios a agregar.

b) Que lo acuerden los habitantes de dicho municipio o territorio mediante referéndum expresamente convocado, previa la autorización competente al efecto y aprobado por mayoría de los votos válidos emitidos. 
c) Que lo aprueben el Parlamento del País Vasco y, posteriormente, las Cortes Generales del Estado, mediante ley orgánica.

Al amparo de este precepto del Estatuto y casi inmediatamente después de su aprobación, los Ayuntamientos de La Puebla de Arganzón y de Treviño adoptaron, con fechas 17 de octubre y 26 de enero de 1980, respectivamente, sendos acuerdos de incorporación a la provincia de Alava y a la Comunidad Autónoma del País Vasco. Posteriormente, acordaron dar audiencia, de conformidad con lo previsto en el apartado a) del citado artículo a la Comunidad o provincia a la que pertenecen, concediendo un plazo de 15 días al Consejo Regional de Castilla y León y a la Diputación Provincial de Burgos para que formularan las alegaciones que estimaren pertinentes. El 16 y 24 de enero de 1981, las Corporaciones municipales de La Puebla de Arganzón y de Treviño acordaron acumular los respectivos expedientes y elevar al Gobierno la documentación acreditativa del cumplimiento de los requisitos establecidos en el apartado a) del artículo 8 del Estatuto vasco, a fin de que autorizara la convocatoria de un referéndum en el que los habitantes de dichos municipios pudieran decidir democráticamente su incorporación a la provincia de Alava y a la Comunidad Autónoma del País Vasco, conforme determina el apartado b) del citado artículo, por ser de la competencia del Gobierno tal autorización. Con fecha de 10 de febrero de 1981, el Jefe de Secretaría del Presidente del Gobierno de la Nación acusó recibo del escrito y anexos dirigidos a éste y dio traslado de todo ello al Ministro de la Presidencia del Gobierno. Pero la autorización requerida no se tramitó, a pesar de las diversas gestiones llevadas a cabo en este sentido a todos los niveles, incluídas negociaciones del Presidente del Gobierno vasco con el Presidente del Gobierno de la Nación.

Así las cosas, en 1983 se aprobó el Estatuto de Autonomía de Castilla y León (15), cuya Disposición Transitoria 7, en su apartado 3, establece un procedimiento de segregación de enclaves. Dicho precepto es del siguiente tenor literal:

"Para que un territorio o municipio que constituya un enclave perteneciente a una provincia integrada en la Comunidad Autónoma de Castilla y León pueda segregarse de la misma e incorporarse a otra Comunidad Autónoma será necesario el cumplimiento de los siguientes requisitos:

a) Solicitud de segregación formulada por el Ayuntamiento o Ayuntamientos interesados, mediante acuerdo adoptado con el voto favorable de las dos terceras partes del número de hecho y, en todo caso, de la mayoría absoluta de los miembros de dicha o dichas Corporaciones.

b) Informe de la provincia a la que pertenezca el territorio o municipio a segregar y de la Comunidad Autónoma de Castilla y León, favorable a tal segregación, a la vista de las mayores vinculaciones históricas, sociales, culturales, y económicas con la Comunidad Autónoma a la que se solicite la incorporación. A tal efecto, la Comunidad Autónoma de Castilla y León podrá realizar encuestas y otras formas de consulta con objeto de llegar a una más motivada resolución.

c) Refrendo entre los habitantes del territorio o municipio que pretende la segregación, aprobado por mayoría de los votos válidos emitidos. 
d) Aprobación por las Cortes Generales, mediante Ley Orgánica.

En todo caso, el resultado de este proceso quedará pendiente del cumplimiento de los requisitos de agregación exigidos por el Estatuto de la Comunidad Autónoma a la que se pretende la incorporación".

A la vista de este precepto, el Gobierno y el Parlamento vascos presentaron recurso de inconstitucionalidad contra el mismo, habida cuenta de que exigía requisitos no pevistos por el artículo 8 del Estatuto vasco: la mayoría necesaria para adoptar el acuerdo inicial por los Ayuntamientos del enclave en cuestión y el informe favorable de la Comunidad Autónoma a la que pertenece el mismo.

El principal argumento que esgrimian era el de considerar que la mencionada Disposición Transitoria del Estatuto castellano-leonés era inconstitucional por antiestatutaria, al violar la rigidez formal de los Estatutos (en este caso del Estatuto vasco) consagrada en los artículos 147.3 y 152.2 de la Constitu-ción.

Sin embargo, el Tribunal Constitucional desestimó, en su ya mencionada Sentencia 99/86, las pretensiones del Gobierno y el Parlamento vascos, estableciendo que debía aplicarse los procedimientos de ambos Estatutos acumuladamente para el cambio de adscripción de los correspondientes enclaves.

En cuanto a los razonamientos jurídicos de dicha Sentencia, el Tribunal parte de la base de que "...el único parámetro para enjuiciar la validez constitucional de una disposición incluída en un Estatuto de Autonomía es la propia Constitución", no siendo admisible cotejar directamente preceptos estatutarios diversos.

El artículo 147.2. b) de la Constitución establece como contenido mínimo de los Estatutos la delimitación del territorio de la respectiva Comunidad. El Tribunal entiende que cabe incluir también aquí los procedimientos de alteración de dicho territorio y que, además, el hecho de que el artículo 147 establezca como contenido mínimo de los Estatutos ciertas materias es, al mismo tiempo, una garantía de que éstas no serán objeto de regulación fuera del correspondiente Estatuto, "pues ello entrañaría la mediatización de la directa infraordenación de los Estatutos a la Constitución, siendo así que, como hemos señalado anteriormente, ésta constituye el único límite que pesa sobre ellos. La predeterminación del contenido de unos Estatutos por otros en virtud, meramente, de la contingencia de su momento de aprobación, ampliaría los límites en que han de enmarcarse los contenidos estatutarios. ...De todo lo anterior se deduce que, contra lo que los recurrentes entienden, el Estatuto de una Comunidad Autónoma no puede regular de un modo 'completo y acabado' la segregación y correspondiente agregación de los enclaves ubicados en su territorio cuando éstos pertenecen al de otra Comunidad Autónoma. La regulación estatutaria no puede contener el procedimiento de modificación territorial que deberán seguir las dos Comunidades implicadas, sino tan sólo el proceso de formación y manifestación de la voluntad de cada una de ellas para perfeccionar -mediante actos distintos pero complementarios- el complejo procedimiento en que consiste la segregación de un enclave y su agregación a otra Comunidad". Por tanto, llega a la conclusión de que el Estatuto vasco sólo puede regular la agregación de los enclaves situados en territorio del País Vasco, mientras que la regulación de la segrega- 
ción queda reservada al Estatuto de la Comunidad a la que pertenecen dichos enclaves y, en el caso del Condado de Treviño, al Estatuto castellano-leonés.

El razonamiento del Tribunal es compartido, entre otros, por Martín Mateo (16), Ruipérez Alamillo (17) y Rivero Ysern (18).

El Magistrado Jesús Leguina Villa formuló un voto particular a esta Sentencia, discrepando del fallo de la misma. Entiende este Magistrado que el Tribunal debía haber declarado la inaplicabilidad de la disposición impugnada al caso del Condado de Treviño, al impedir los artículos 147.3 y 152.2 de la Constitución cualquier reforma de los Estatutos que no se ajuste al procedimiento establecido en los mismos: "Si a un mismo enclave -en el caso, el Condado de Treviño- se aplicara la Disposición transitoria séptima, 3, del Estatuto de Castilla-León, que regula de modo parcialmente contradictorio el camino a seguir para la integración de dicho enclave en el territorio del País Vasco, se estaría automáticamente inaplicando el citado artículo 8 del Estatuto vasco, lo que es tanto como decir que este precepto estatutario resultaría derogado o modificado, al menos parcialmente, por una vía distinta de la señalada en el artículo 152.2 de la Constitución y en el artículo 46 del propio Estatuto vasco. Como quiera que la Constitución prohibe cualquier modificación extra ordinem de los Estatutos, resulta forzoso concluir que la validez de la norma transitoria del Estatuto castellano-leonés sólo es posible si se entiende que queda fuera de su ámbito de aplicación el supuesto del enclave territorial contemplado y regulado por el artículo 8 del Estatuto vasco. Una conclusión distinta, como es la que se mantiene en la Sentencia mayoritaria, implica admitir la posibilidad de derogación o modificación de un Estatuto anterior por otro posterior, con inobservancia o desconocimiento del mandato constitucional antes dicho".

Este último razonamiento es defendido, entre otros, por Larumbe Biurrun (19) y Sánchez Blanco (20).

Luis María Díez-Picazo (21) considera correcto el fallo del Tribunal, aunque matiza algunos puntos de la argumentación recogida en la Sentencia. A diferencia de ésta, entiende que es perfectamente posible que un Estatuto -en este caso el vasco-regule de forma completa y acabada el procedimiento de incorporación de enclaves situados en su territorio. En cuanto a la eventual objeción de que tan sólo el Estatuto de Autonomía de Castilla y León estaba constitucionalmente habilitado para regular la segregación-agregación del Condado de Treviño y que la regulación efectuada por el Estatuto vasco significa una extralimitación y sería inaplicable porque el principio de territorialidad de las normas de Derecho Público le impediría desplegar su eficacia en territorio no vasco, Díez-Picazo replica anticipadamente con un argumento a todas luces acertado: "los Estatutos de Autonomía son leyes orgánicas dictadas por el Estado y, por ello, vinculan indiscriminadamente en todo el territorio nacional, según su fórmula de promulgación se ocupa de advertir".

El argumento básico en que se basa para no considerar correcto el razonamiento del Magistrado Leguina Villa es el de entender que las cláusulas de rigidez estatutaria no son aplicables entre los propios Estatutos de Autonomía. Entiende que "... la afirmación de la operatividad de las cláusulas de rigidez estatutaria frente a otros Estatutos lleva inevitablemente a sostener la jerarquización entre Estatutos de 
Autonomía. Y ello repugna también a la conciencia del jurista porque no tiene apoyo constitucional alguno, porque todos poseen la misma naturaleza, porque todos forman parte del bloque de la constitucionalidad y, sobre todo, por una razón aún más profunda, a saber: esa jerarquización estaría determinada por el mero hecho de que unos Estatutos se promulgaron antes que otros,... esta postura significa que también en materia de autonomía la antigüedad es un grado".

Curiosamente, el propio Diez-Picazo nos da la clave para descubrir la incorrección de su razonamiento al afirmar: "... hoy día es pacífico en la doctrina española, con el decisivo respaldo de la jurisprudencia constitucional, que no todo caso de rigidez -esto es, de especiales requisitos que dificultan la modificación o derogación de una norma, dotándola de una peculiar fuerza pasiva- es expresión de una diferencia de rango jerárquico. Valga por todos el ejemplo de las leyes orgánicas...". Y, en efecto, esto es lo que sucede en el caso del razonamiento del voto particular. Afirmar, como hacemos los que compartimos dicho razonamiento, que las cláusulas de rigidez estatutaria sí son aplicables entre los propios Estatutos no supone necesariamente partir de la premisa de que entre ellos hay diferencias jerárquicas. Cosa distinta es que una interpretación literal del artículo 147.3 de la Constitución conlleve el mismo resultado práctico que si se partiera de dicha premisa, al producirse el efecto que Díez-Picazo describe gráficamente al decir que "también en materia de autonomía la antigüedad es un grado". Pero el hecho de que este efecto no sea considerado conveniente desde un punto de vista de política legislativa no permite afirmar que las cláusulas de rigidez estatutaria no son aplicables entre Estatutos, porque ello supone sencillamente obviar la literalidad del artículo 147.3 de la Constitución, cuya interpretación no deja lugar a dudas. Por otra parte, habida cuenta de la naturaleza de los Estatutos, son muy escasos, en la práctica, los supuestos en los que pueden entrar en colisión entre sí.

En definitiva, la Constitución establece que los Estatutos de Autonomía son leyes orgánicas y, por tanto, tal es el rango que tienen. La rigidez estatutaria obedece al carácter paccionado de los Estatutos (22) pero ello no implica, desde el punto de vista formal, un mayor rango jerárquico (23).

En cuanto al argumento del Tribunal Constitucional según el cual los procedimientos de alteración del territorio de una Comunidad Autónoma forman parte del contenido mínimo de su Estatuto, no parece que sea acorde con la literalidad del artículo 147.2.b) de la Constitución, que sólo habla de delimitación del territorio. Prueba de ello es que, como hemos visto en el epígrafe anterior, muy pocos Estatutos han regulado de modo específico esta cuestión.

Para terminar, resulta oportuno recordar que, hasta el momento de aprobarse el Estatuto vasco, el Estado tenía plena disponibilidad en lo que se refiere a los enclaves intracomunitarios situados en la Comunidad Autónoma del País Vasco. Podría no haber admitido regulación alguna de esta materia en el Estatuto; por contra, también podría haber utilizado la Ley Orgánica que aprobó dicho Estatuto para adscribir directamente el Condado de Treviño a Alava. Y, en uso de esa plena disponibilidad, pactó con los representantes de los territorios vascos que accedían a su autonomía un procedimiento de incorporación que, dado ese carácter paccionado, queda 
protegido, al igual que el resto del Estatuto, por la rigidez formal consagrada en los artículos 147.3 y 152.2 de la Constitución. Cuando los castellano-leoneses accedieron a la autonomía ya no podían reivindicar su derecho a regular la segregación del Condado de Treviño, porque esa regulación ya había sido hecha tres años antes por quien tenia plena disponibilidad para hacerlo, quedando afectada por la rigidez estatutaria.

Lo cierto es que la Sentencia comentada volvió a dejar en vía muerta la cuestión del Condado de Treviño, dando al traste con un nuevo intento de incorporación a Alava.

Como conclusión final bien puede decirse, dado el escaso interés que, en general, despierta la cuestión de los enclaves, que el fin de éstos no se adivina ni siquiera a largo plazo.

NOTAS.

(1) Sentencia del Tribunal Constitucional 99/86 de 11 de julio. B.O.E. de 23 de julio de 1986.

(2) GOMEZ FERNANDEZ, L., "Apostillas históricas a la Sentencia del Tribunal Constitucional sobre la incorporación de Treviño al País Vasco", en Revista de Derecho Público, núms. 104-105, pág. 611.

(3) MARTIN-RETORNILLO, S., "En torno a la organización provincial", en Revista de Administración Pública, num. 93, págs. 17 y ss.

(4) Acerca del reconocimiento que el vigente Reglamento de Población y Demarcación (Real Decreto 1690/1986) hace de los enclaves municipales existentes, véase su art. 1.

(5) LARUMBE BIURRUN, P.M., El territorio de la Comunidad Autónoma: notas jurídicas, IVAP, Oñati, 1988, pág. 62.

(6) Sin embargo, no es infrecuente encontrar textos en los que se afirma que el Rincón de Ademuz es un enclave de la Comunidad Valenciana dentro de Aragón. La consulta de cualquier mapa demuestra lo incorrecto de tal afirmación.

(7) MATEU I LLOPIS, El País Valencià, Valencia,1933, pág 101.

(8) Real Decreto Legislativo 781/1986, de 18 de abril. B.O.E. núm. 96, de 22 de abril.

(9) Ley Orgánica 2/80, de 18 de enero. B.O.E. núm. 20, de 23 de enero de 1980.

(10) RIVERO YSERN Y OTROS, Comentarios al Estatuto de Autonomía de la Comunidad Autónoma de Castilla y León, IDEAL, Madrid, 1985, págs. 335 y 336.

(11) DIEZ-PICAZO, L.M., "Sobre la delimitación estatutaria del territorio de las Comunidades Autónomas y la rigidez estatutaria", en Revista Española de Derecho Constitucional, núm. 20, 1987, pág. 149.

(12) El artículo 10 del Estatuto de Autonomía de Aragón es del siguiente tenor literal:

"Podrán incorporarse a la Comunidad Autónoma de Aragón otros territorios o municipios, limítrofes o enclavados, mediante el cumplimiento de los requisitos siguientes, sin perjuicio de otros que puedan legítimamente exigirse:

a) Que soliciten la incorporación el Ayuntamiento o la mayoría de los Ayuntamientos interesados y que se oiga a la Comunidad o provincia a la que pertenezcan los territorios o municipios a agregar. 
b) Que lo acuerden los habitantes de dichos municipios o territorios, mediante consulta expresamente convocada al efecto y previa la autorización competente.

c) Que lo aprueben las Cortes de Aragón y, posteriormente, las Cortes Generales del Estado, mediante Ley Orgánica".

(13) GOMEZ FERNANDEZ, L., "Apostillas históricas...", cit., págs. 620 y 621.

(14) Ley Orgánica 3/79 de 18 de diciembre. B.O.E. de 22 de diciembre de 1979.

(15) Ley orgánica 4/83 de 25 de febrero. B.O.E. de 2 de marzo de 1983.

(16) MARTIN MATEO, R., Manual de Derecho Autonómico, Madrid, 1986, pág. 95.

(17) RUIPEREZ ALAMILlO, J., "Problemas en la determinación territorial de las Comunidades Autónomas", R.E.P., núm. 56, pág. 178.

(18) RIVERO YSERN Y OTROS, "Comentarios...", cit., págs. 335 y 336.

(19) LARUMBE BIURRUN, P.M., El territorio..., cit., pág. 80.

(20) SANCHEZ BLANCO, A., "Ajustes territoriales en las Comunidades Autónomas. Derechos institucionales y derecho de las comunidades sociales. La Sentencia del Tribunal Constitucional 99/1986 relativa al Condado de Treviño", en R.V.A.P., núm. 16, 1986, págs. 153 y 154.

(21) DIEZ-PICAZO, L.M., "Sobre la delimitación...", cit., págs. 166 y 167.

(22) Dicho carácter paccionado, ampliamente admitido en la doctrina, es rechazado a su vez por DIEZ-PICAZO, L.M., en "Sobre la delimitación...", cit., pág. 165.

(23) Puede verse en este sentido la explicación dada por TORRES DEL MORAL, A., Principios de Derecho Constitucional, Madrid, 1985, tomo 1, págs. 54 y 55. 



\section{RESÚMENES DE TESIS DOCTORALES}





\title{
EL BANCO DE ESPAÑA: ASPECTOS JURIDICO-FINANCIEROS
}

\author{
EVA ALIAGA AGULLO
}

Es innegable que uno de los hechos más importantes que han caracterizado la vida económica española de los últimos años, ha sido el creciente protagonismo asumido por el Banco de España en el funcionamiento de la economía nacional.

La promulgación en 1980 de la Ley de Organos Rectores, supuso el reconocimiento de un ámbito funcional específico de libre desenvolvimiento para el Banco de España, en orden a la consecución de un fin que la ley le atribuye como propio, cual es, el de salvaguardar el valor del dinero.

En tal sentido, el Banco de España al que se concede una indudable discrecionalidad técnica y operativa, se convierte en un ente público de perfiles difícilmente encajables en la ordenación positiva española, en marcha hacia una efectiva independiencia real respecto de la Administración del Estado garantizada por una autonomía orgánica, un ámbito propio funcional independiente en determinados aspectos del Gobierno, una misión institucional propia atribuida por la Ley y una indudable capacidad normativa. No obstante, la nueva configuración orgánica y funcional del Banco de España como consecuencia de la adaptación que, en su caso, habrá de efectuar al Estatuto de Banco Central Europeo, exigirá que el elgislador español modifique su actual Estatuto jurídico.

El análisis del Banco de España desde el mundo del Derecho Financiero a través de las relaciones que éste guarda con los principios propios de esta disciplina y con los institutos jurídicos de la que ella se ocupa, es lo que conforma el núcleo central de esta investigación.

En el estudio de los aspectos jurídico-financieros de la actividad del Banco de España abordamos, como tema fundamental, la delimitación de este instituto en base a la pluralidad de funciones desempeñadas por el mismo.

El análisis, desarrollo y sistematización jurídico-positiva de cada uno de los aspectos que componen el ámbito funcional del Banco de España, permite concluir que es un Instituto de carácter complejo que desempeña en su actividad funciones de diversa índole y naturaleza, dentro de las cuales y como parcela específica de las mismas, se pone de relieve la existencia de ciertas manifestaciones jurídico-financieras que responden, en definitiva, al desarrollo de las funciones de carácter financiero atribuidas por el ordenamiento jurídico al Banco de España.

En primer lugar, el Banco de España es un Instituto colaborador de la Hacienda. Al mismo tiempo, el Banco de España, ente con funciones financieras propias se convierte en un Instituto independiente, dotado de un ámbito financiero propio manifestado en la capacidad para ser titular de los derechos económicos resultantes 
de la aplicación de sus recursos propios, así como para asumir las necesidades públicas cuya satisfacción la encomienda el ordenamiento jurídico.

No obstante, el conjunto de funciones financieras que configuran jurídicamente la actividad financiera del Banco de España, son sólo un aspecto de su gestión pública. Junto a ellas y en la medida que es compatible con éstas aparece un interés recaudador, esto es la consideración del Banco de España como fuente productora de sus ingresos para el Tesoro Público.

Por ello, la Hacienda del Banco, configurada de modo autónomo, que responde a una idea organizadora distinta de la del Estado, es en definitiva, una Hacienda interna de la Hacienda del Estado porque los rendimientos de su actividad son derechos económicos de la Hacienda Estatal y constituyen una parte del haber de la misma.

Finalmente, hemos de poner de relieve que el Banco de España como Instituto financiero independiente deberá someterse a los principios materiales y formales que presiden el ejercicio de las funciones financieras públicas, así como a los mecanismos de control que respecto de la actividad financiera ha elaborado el Derecho Público.

La acomodación normativa a las exigencias planteadas en nuestra Tesis Doctoral, perfilan el futuro de una entidad cuyos aspectos jurídico-financieros hemos pretendido destacar en el presente trabajo. 


\section{ESTUDIOS JURIDICO-SOCIALES SOBRE LOS INDIOS GUAYMI}

\section{JOSE LUIS IGLESIAS SEQUEIROS}

El trabajo de investigación que se pretendió a través de este estudio fue profundizar sobre las razas autóctonas que habitaron el Itsmo de Panamá, tomando para ello dos fases, antes de la Conquista y después de la Conquista.

En la primera época, las etnias que estaban representadas, eran los Talamacas, Cunas, Teribes, Bri-Bri y Bokotas, de todas esas razas los estudios son más escasos, sólo a través de los arqueólogos descubrimos vestigios de su forma de vida y cultura, por los hallazgos arqueólogicos que se encontraron en las zonas que estuvieron habitadas.

Todas estas culturas, más tarde se irían fusionando entre sí quedando divididas en tres grupos:

Grupos indígenas de la Región Oriental.

Grupos indígenas de la Región Occidental.

Grupos indígenas de la Región Central.

En la actualidad de todas estas razas y extrayendo de ellas sus rasgos físicos característicos quedan las Guamíes, Cunas y Chocoes.

En el art. 116 de la Constitución Panameña, dice el Estado garantiza a estas reservas la tierra necesaria para que vivan dentro de sus dominios y conserven su cultura e idiosincrasia.

Debemos de reconocer que si bien al indígena no se le ataca directamente, socialmente no goza de las mismas oportunidades ni prestaciones sociales que se pretende, y en el art. 85, de la Constitución del año 1972, el Estado reconoce y respeta sus lenguas, cultura y forma de vida.

Esto sería un gran objetivo si se consiguiese en la práctica y fuese acompañado de campañas de salud, escolarización, vías de comunicación, y aportaciones, que respetando su forma de vida garantizase un contacto con el mundo occidental que de alguna manera les matiene marginados.

En los siglos XVII y XVIII, Panamá por su situación geográfica, goza de ser un puente entre dos oceános. Ello motivó a que fuese punto de mira de varios países que empezaron a meditar la construcción de un canal interoceánico. Ruben de Carles en su libro "220 años de período de Conquista" ya manifiesta el interés que desperto este país.

El comercio ya existía entre países colonizados, precisamente Panamá fue un enclave importante en la famosa ruta del oro, pues todos los galeones que pasaban a través del río Chagres que era navegable, por donde más tarde pasaría el Canal de 
Panamá, era paso obligado para el comercio desde Europa a los países de Ecuador, Perú y Chile, por todo ello despertó precisamente Panamá mucho interés al tratarse de ser un puente entre dos océanos.

Investigando los indio guamíes, nos encontramos que ya en la época de la Conquista, tenían un territorio enclavado en la provincia de Chiriquí ocupando además parte de Bocas del Toro que limita con Costa Rica, estos indios en la actualidad son la raza más numerosa y siguen ocupando la misma zona aunque han sido desplazados para la serranía. Las tierras fértiles que ocupaban han sido ocupadas por los Castelauros, así se denominaban los conquistadores.

No se respetó en lo más mínimo en estas invasiones las razas que allí vivían, sin ánimo de dramatizar a estos indios se les obligó, a dejar sus tierras haciéndoles huir de sus poblados apoderándose el conquistador de sus pertenencias sin respetar en lo más mínimo su forma de vida.

Actualmente se han celebrado conferencias, coloquios y existe una sensibilidad que intenta corregir los males pasados y concretamente en el año 1971, el General Torrijos, en el Consejo General del Bayano, ante la Cámara de representantes insta al Gobierno Panameño para que reconozca una realidad histórica de hecho y de derecho, se le dé a estas razas indígenas medios sanitarios, y de salud para su autogobierno, respetando normas y costumbres y por último el Gobierno Nacional respete su condición y autoridad regional dentro de la Administración Panameña.

Los guaimíes complen el Patrón de Asentamiento en aldeas debido a la región montañosa en que viven las viviendas son un jorón de paja en forma cónica y techo con rama de palma, el tipo de vivenda está condicionado porque habitan la región más lluviosa del país.

El estudio socio-económico de esta reserva se calcula que viven unos cincuenta y dos mil hombres, administrativamente se rigen por un Cacique, cada comarca tiene uno, dentro de la reserva existen tres regiones, cada región tiene un Cacique, que gobierna la región én que vive, y después el Cacique Supremo, que es la máxima jerarquía de toda la reserva.

El Cacique en la Jerarquía Administrativa y Judicial hace las funciones de Corregidor y se someten a su criterio las fricciones de los miembros de la reserva.

A nivel de la representación Política Nacional, en la Asamblea de Representantes de corregimientos después de la Constitución de 1927, los guaymíes han logrado estar representados por 32 curules. Incluso dentro del Consejo Nacional de Legislación obtuvieron una plaza por Bocas del Toro y otra por Chiriquí.

No existe en el pueblo guaymí derecho de propiedad, solamente se tiene la posesión vitalicia del trozo de tierra que se cultiva y la casa donde se vive. La figura del pater-familia está muy arraigada, se consideran mayores de edad cuando se emancipan los hijos de la familia por matrimonio y viven de forma independiente. La mujer nunca disfruta de derecho pleno, primero depende del padre y más tarde del marido, la forma de matrimonio es la poligamia, cada hombre tendrá el número de mujeres que pueda mantener, al matrimonio se llega de dos modalidades, o por contrato oral entre los padres de los desposados, o por medio de la balsería. 
La balsería es uno de los deportes de más arraigo dentro de la reserva, se reúnen los indios de diferentes reservas y el deporte consiste en un juego a manera de desafío que se reta al competidor con una estaca de aproximadamente cinco pies de largo, propinándole al contrario golpes en pantorrillas y tobillos, haciendo movimientos giratorios de forma rutinaria así hasta vencer al competidor.

Alrededor del juego se juntan espectadores que consumen comidas y bebidas como la chicha fuerte. La fiesta dura varios días, hasta que existe en el deporte un vencedor, si el motivo de la balsería ha sido para matrimonio este tiene derecho a elegir doncella entre las que se han presentado como casaderas. Después de la balsería comenzará la fiesta nupcial.

Otras fiestas de vital importancia en la reserva son las de la pubertad femenina, la pubertad masculina, de menos importancia que la anterior y los enterramientos que constituyen un acto social de relevancia en que se participa varios días y ya desde épocas ancestrales según la escala social del difunto se entierran o se embalsaman. Si se trata de un Cacique se embalsama y en huacas se guardan sus pertenencias. 


\title{
LAS CRISIS BANCARIAS. LOS PROBLEMAS JURIDICOS QUE PRODUCEN Y LAS SOLUCIONES DEL ORDENAMIENTO JURIDICO
}

\author{
FELIX MATEO MATEO
}

1. Estructura del trabajo: Se divide en cuatro partes y conclusiones.

2. En la primera parte, se examinan, además de las cuestiones introductorias, los antecedentes de la banca organizada, tanto privada como pública, los perfiles del sistema bancario modemo, su evolución y estado actual, los episodios de crisis bancarias, producidas en la historia financiera, con referencia especial al período más reciente, en el que la mitad de los bancos existentes en España, han visto comprometida su liquidez o solvencia, a finales de los años setenta. Se presta atención a la formación de la banca, dando noticia de los sistemas modemos comparados.

En el plano normativo son analizados los preceptos que regulan las crisis empresariales y especialmente, las reglas existentes sobre la quiebra de las sociedades mercantiles. Los bancos como sociedades mercantiles especiales cobran relevancia al hablar de la crisis, o al tratar la cuestión de las normas sobre suspensión de pagos o quiebra, destacando el escaso valor práctico de los procedimientos del ordenamiento jurídico español sobre quiebras, aplicados a la quiebra de un banco.

En esta parte, también se examinan los ordenamientos jurídicos comparados, especialmente de Alemania, Inglaterra, Italia, Francia y Estados Unidos, que son significativos de las soluciones dadas a las crisis bancarias, así como las Directivas del ordenamiento comunitario sobre la banca y entidades de crédito, dada la incidencia de las mismas sobre el ordenamiento español.

3. La segunda parte comprende el examen de los problemas jurídicos que plantean las crisis bancarias, en relación con los intereses de los depositantes, los acreedores, los accionistas, los trabajadores y el interés general del sistema financiero. En la misma se resalta el carácter primordial de los intereses afectados por la crisis; siendo a este propósito obligado destacar la relevancia del fenómeno en los intereses de los depositantes y de los accionistas o inversores.

4. La tercera parte comprende el examen de las medidas adoptadas desde la perspectiva jurídica, a veces medidas provisionales, tanto de carácter preventivo como corrector, en el ordenamiento jurídico español, como la creación del Fondo de Garantía de Depósitos y el reforzamiento de las funciones del Banco de España en relación con la banca privada, y en el ordenamiento comparado, destacando los instrumentos creados al efecto en los ordenamientos de Alemania, Italia, Francia, Inglaterra, así como las formas de corregir los problemas que produce la crisis de los bancos en el ordenamiento norteamericano. 
5. En la cuarta parte se hace una recapitulación del estado de la cuestión, incidiendo en la necesidad de reforma del Ordenamiento Jurídico; se postula la necesidad de un ordenamiento regulador del sector bancario, debido a que las medidas dictadas hasta el momento, han sido insuficientes, y dado que la especificidad de la actividad bancaria, hace obligada la intervención de las autoridades monetarias, es necesario regular nuevas normas sobre inspección y control de la actividad bancaria, y dictar normas sobre las responsabilidades por su ejercicio. En último término se hace una reflexión sobre la actividad bancaria y sus crisis, así como sus perspectivas futuras, y soluciones para evitar y prevenir las crisis de los bancos, en atención a la concentración bancaria, entidades más competitivas y de tamaño adecuado con vistas al mercado interior.

6. Por último, se elaboran unas conclusiones, que se dirigen a las siguientes cuestiones:

a) Insuficiencia de las medidas adoptadas hasta el momento por el legislador bancario, sobre todo, en relación con las disposiciones dictadas para tutelar intereses afectados o instrumentos jurídicos adoptados, insuficientes e incapaces para resolver de manera satisfactoria problemas de tutela efectiva de los derechos concernientes. Así, es necesario regular responsabilidades no solo contractuales como empresa, sino responsabilidades derivadas de actividades específicas como empresa bancaria y extracontractuales.

b) Se hace precisa una nueva ordenación sistemática de la actividad bancaria, para evitar la elaboración de disposiciones conyunturales con motivo de dificultades o crisis bancarias.

c) Especial regulación de estas empresas a fin de tutelar los intereses del accionista y del inversor, creación de instituciones de protección del inversor, con establecimiento de normas que regulen sistemas de responsabilidad específica, en atención a la especial actividad, se definan sanciones administrativas e incluso penales, para los infractores que actúen con abuso o fraude a los inversores, accionistas y depositantes.

d) Clarificación de normas sobre solvencia y garantía de bancos, a fin de prevenir situaciones de crisis, hacer frente a la excesiva concentración de riesgos que pongan en peligro el sistema financiero, propugnando la objetivación del derecho paraconcursal bancario.

e) Necesidad de reforma en profundidad de la legislación sobre crisis empresariales y en especial del derecho concursal bancario, dentro del esquema y marco de la reforma general emprendida en el derecho mercantil español. 


\title{
LA CONFESIONALIDAD, PIEZA CLAVE EN LA HISTORIA CONSTITUCIONAL ESPAÑOLA Y EN EL REGIMEN FRANQUISTA.
}

\author{
Pfra. NIEVES MONTESINOS I SANCHEZ
}

Los sistemas de relación Iglesia-Estado han sido muchos y cambiantes a lo largo de la historía, pudiéndose establecer una diferenciación básica que vendría dada por aquellos que se han asumido o han sido defendidos por la Iglesia, y aquellos otros que lo han sido por parte del Estado; pero hay un dato evidente, en la base de todos y cada uno de ellos subyace una determinada doctrina que lo sustenta y en consecuencia la evolución y desarrollo de las doctrinas y filosofías traerá siempre consigo un cambio sustancial en los sistemas de relación entre la Iglesia y el Estado, aunque no podemos olvidar que en ocasiones las tesis han sido elaboradas para intentar justificar los diferentes sistemas. Existirá pues siempre un sistema jurídicopolítico-religioso y una subyacente concepción filosófico teológica.

El trabajo tiene como objetivo fundamental adentrarnos en el complejo mundo de las relaciones Iglesia-Estado en nuestro país, utilizando para ello como hilo conductor del mismo los diferentes textos legales, en los que incluso con muy diferente rango normativo, se ha plasmado esta cuestión; decantándose en la mayoría de ellos por la formulación de un Estado confesional.

Si bien la intención inicial era en exclusiva el régimen franquista, la imposibilidad, pensamos, de abordar directamente su estudio hizo que este primer planteamiento se abriera para dar cabida a determinadas cuestiones que consideramos imprescindibles en aras a la elaboración de una base lo más sólida posible sobre la que apoyar y fundamentar nuestro trabajo.

Es por ello, por lo que la Tesis aparece sistemáticamente dividida en dos partes básicamente diferenciadàs pero no por ello carentes de relación hasta el punto de ser absolutamente independientes.

En la primera, que hemos considerado adecuado titular genéricamente: "Evolución histórica y conceptual", se abordan las siguientes cuestiones en los capítulos que la integran:

El capítulo primero, recoge el estado de la cuestión desde una perspectiva terminológica y conceptual, lo que nos obliga al análisis de los diversos sistemas de relación entre la Iglesia y el Estado y de las formas que adoptan los sistemas jurídico-político-religiosos; para detenernos en último lugar en las aportaciones e innovaciones que supuso la doctrina del Concilio Vaticano II.

El capítulo segundo, con el que se cierra la primera parte, lo hemos dedicado integramente a la historia del Derecho Constitucional español. La cuestión religiosa tuvo cabida en todos los textos constitucionales que vieron la luz, e incluso los que 
no la vieron, a lo largo del siglo XIX y principios del XX. Debates e instituciones eclesiásticas aparecen y desaparecen en consonancia con el paso por el poder de liberales, moderados o conservadores; haciendo caso omiso, en muchas ocasiones, de la fórmula que en lo concerniente a las relaciones Iglesia-Estado había quedado plasmada en el texto constitucional.

El régimen franquista ocupa la segunda parte. Habida cuenta de la amplitud temporal del periodo, el tratamiento del tema es eminentemente jurídico. La excepción, que no absoluta, la constituye el capítulo tercero, ya que era imprescindible examinar los pilares del nuevo Estado, si bien desde una optica precisa. Así, los origenes de las relaciones Iglesia-Estado y los orígenes de la configuración ideológicopolítica del régimen han sido los temas examinados.

A partir de estas consideraciones los capítulos siguientes se centran en la legislación, la cual hemos dividido en tres grupos de estudio, a saber: las Leyes Fundamentales, la legislación concordada y la legislación de desarrollo. Merece destacarse el hecho de que la confesionalidad que proclaman y defienden los principios fundamentales impregnará todas las estructuras e instituciones del Estado, dando también buena cuenta de las tensiones y conflictos siempre latentes entre ambos poderes.

La adecuación a los principios del Estado confesional del régimen franquista sufre una ruptura de importancia singular a raiz de las doctrinas del Vaticano II. Las reformas que fundamentadas en las mismas se introducen en la legislación, son mínimas. La razón, nos parece, no es otra que la inseparabilidad del binomio unidad espiritual-unidad nacional.

El régimen franquista se decantó, en suma, por una confesionalidad formal haciendo de ella una cuestión más política que social y jurídica. Las reformas no podían ir más allá, la unidad espiritual no podía verse amenazada ya que su resquebrajamiento podía dañar la unidad nacional.

Además, obviamente, de las conclusiones propias, se cierra el trabajo con un apéndice en el que se realiza una breve panorámica del estado de la cuestión en el Derecho Comparado. 


\title{
"ASPECTOS JURÍDICOS-FINANCIEROS DEL DÉFICIT PÚBLICO"
}

\author{
AMPARO NAVARRO FAURE
}

El núcleo de esta investigación es la reconducción del fenómeno del déficit público al mundo del Derecho Financiero a través de las relaciones que éste guarda con los institutos jurídicos del Presupuesto, los ingresos públicos y los gastos públicos, y los conceptos básicos de actividad financiera y de Hacienda Pública.

A partir del primer capítulo dedicado a sistematizar las aportaciones más relevantes en la Ciencia Económica con respecto al déficit, la tesis se estructura en tres capítulos: el déficit y el Presupuesto, el déficit y el ingreso público y el déficit y el gasto público.

A lo largo de estos cuatro capítulos y por medio de la investigación de las aportaciones doctrinales y de la legislación vigente, a modo de síntesis, se extraen las siguientes conclusiones.

El llamado déficit público, como fenómeno que se puede producir en el desarrollo de la actividad financiera de cualquier ente público, consiste en una determinada combinación de los recursos públicos, en donde el recurso al crédito concurre con el resto de los recursos en la financiación de los gastos públicos.

El déficit público participa del carácter político de las decisiones que integran la actividad financiera. Por lo tanto, el fenómeno estudiado no es un efecto automático de una determinada coyuntura económica, sino de la decisión política, y jurídicamente posible, de no financiar la totalidad de los gastos públicos a través de los recursos tributarios o patrimoniales.

El déficit que aparece en el Presupuesto surge de la comparación entre el estado de ingresos tributarios y la cuantía de los créditos presupuestarios. Esta comparación se realiza, por tanto, sólo en una de las fases o niveles de ambos institutos, que no da conocimiento del resultado de la actividad financiera. $Y$ ello no sólo porque el estado de ingresos puede no coincidir con lo efectivamente recaudado sino porque los créditos presupuestarios, a través de los suplementos de crédito, los créditos extraordinarios o los créditos ampliables convierte, también, a efectos del déficit, en previsibles las cifras del estado de gastos.

Los Presupuestos Generales del Estado son sólo un punto de referencia del déficit en la medida en que ponen de manifiesto la conexión jurídica anual entre derechos liquidables y obligaciones reconocibles.

No existe para el Estado en Derecho Financiero un principio de equilibrio presupuestario, en el sentido de que los ingresos tributarios deben ser suficientes para financiar los gastos públicos, desde el momento en que el Ordenamiento jurídico no recoge la división entre ingresos ordinarios y extraordinarios. El carácter histórica- 
mente cambiante de esta distinción arrastraría también a un concepto variable del equilibrio y del déficit.

En la fase de aprobación del Presupuesto, el único principio posible es el del equilibrio contable que, arrinconado por el principio de equilibrio económico, cumple una importante función informadora acerca de la combinación de los recursos con los que se pretende cubrir por un período determinado los gastos públicos autorizados para ese mismo período.

La utilización de la Deuda pública no ha de responder necesariamente a la existencia de una insuficiencia tributaria, sino a la política deliberada del poder público de no acudir a otros recursos más gravosos políticamente.

La habitualidad en la utilización de la Deuda pública, unida a la intervención del Estado a través de este recurso en el mercado de capitales, ha propiciado una regulación más flexible de la Deuda pública que se manifiesta, principalmente, en la ausencia de un destino específico para el producto de la Deuda y una mayor competencia del Ejecutivo en la regulación de este recurso.

El crecimiento del gasto público o incluso el mismo nivel de gasto no tiene que ser financiado, como el déficit demuestra, exclusivamente por recursos tributarios. Ni una interpretación más amplia de la capacidad contributiva ni, en consecuencia, una mayor recaudación por vía tributaria tienen por qué reducir el déficit, ya que mayores recursos permiten satisfacer nuevas necesidades que, a su vez, pueden redundar en una mayor capacidad contributiva de los particulares. Sólo una limitación constitucional que obligara a financiar todo el gasto público a través de los recursos tributarios convertiría a la capacidad contributiva en el límite del gasto público y del déficit.

Es desde el prisma de la justicia financiera como se debe analizar y valorar la superación deliberada del límite de los recursos disponibles. El déficit público sólo puede ser jurídicamente censurable cuando no se estén destinando los recursos públicos a la satisfacción de las necesidades públicas, o cuando la decisión respecto a la satisfacción de dichas necesidades no se adecúe a la voluntad mayoritaria.

El artículo 31.2 de la Constitución proporciona no sólo los criterios a los que debe responder la regulación del gasto público sino, por lo que hace al tema de la tesis, unos elementos de juicio que permiten pronunciarse acerca de la idoneidad del déficit público al fin de la actividad financiera del Estado. 


\title{
ANALISIS DE LAS AGRAVANTES ESPECIFICAS DEL HURTO Y DEL ROBO CON FUERZA EN LAS COSAS
}

\author{
JOSÉ RAMON SORIANO SORIANO
}

El tema central o nuclear de este trabajo de investigación lo constituye el estudio pormenorizado de todas y cada una de las agravatorias previstas en los arts. 506 y 516 del Código Penal. De rechazo se analizan también los arts. 508 y 501, párrafo final. El primero de ellos por constituir el concepto auténtico de la circunstancia locativa de casa habitada (art. 506-2), y el último, por imponerse una delimitación con la circunstancia hermana de uso de armas, frente al simple porte.

Antes que nada, fue preciso partir de la naturaleza jurídica de las circunstancias epecíficas, para obtener las pertinentes consecuencias en el plano penológico. Mas, lo que pudo haber sido un simple dato de partida, se convirtió en una especie de Parte General de la Tesis, en la que se realizaba un somero estudio de las circunstancias en general para terminar encuadrando en una determinada, dirección, las que eran objeto de análisis y las demás que merecieran la calificación de específicas. Tal extensión analítica la imponía la contradictoria conceptuación de las circunstancias específicas, fruto de las respectivas tesis doctorales de dos monografistas destacados, que mantenían posturas encontradas. De haber coincidido en tal cuestión, no hubiera merecido ninguna atención el problema. Nos referimos a los profesores Mercedes Alonso Alamo y José Luis González Cussac. Al criterio de la primera, que reputaba auténticas circunstancias a las específicas, se contraponia el del segundo, que las consideraba como complementos típicos, originadores de figuras delictivas cualificadas.

Nuestro estudio concluye en una posición ecléctica, más próxima a los criterios sostenidos por el segundo. En favor del primer posicionamiento, se estima que, aunque la función normativa o valor legislativo de la agravatoria es la de complementar el tipo (tipos complementados, subtipos agravados), tal integración se producía por medio de una circunstancia, calificada así, únicamente, desde el punto de vista dogmático-material. Esto es, sólo afectaban, de modo secundario, a los elementos conmensurantes del delito: antijuridicidad y culpabilidad. Consecuencia de ello es que, en los casos especiales, que por imprevisión legislativa, resultaran inoperantes las circunstancias específicas, pudieran funcionar con valor y eficacia de genéricas, respecto al delito que agravaban.

Ya dentro del particularizado análisis de las agravaciones, se examinan individualmente, haciendo especial hincapié en la jurisprudencia que las interpreta.

Resumidamente, podemos espigar algún rasgo o característica llamativa de su estudio. En orden al porte de armas, se delimita su campo de acción, deslindándolo 
del uso de armas previsto para el robo violento, del delito de tenencia ilícita y de la agravante genérica, consistente en ejecutar el hecho en la morada del ofendido (art. 10-16 ${ }^{a}$ C.P.). A la hora de precisar el alcance del término arma, se realiza un estudio comparativo con el Reglamento de armas, para concluir que la noción legal es de carácter vulgar, aunque dicho texto normativo, constituya un valioso instrumento interpretativo. Dentro de los objetos peligrosos, que se equiparan a las armas, resulta interesante señalar el límite mínimo de dicho concepto (¿lo serán los palos, piedras, etc?).

Sobre la agravación de casa habitada, se intenta perfilar el concepto auténtico (art. 508), recuciendo la amplitud que el Tribunal Supremo otorga a dicha noción. En contra del mismo se excluyen las viviendas de fines de semana o vacaciones, salvo que el robo se cometa en esos períodos. También se reduce, contrariando posiciones del Tribunal Supremo, el contenido y alcance del concepto de dependencia de casa habitada, que la entendemos como dependencia de la vivienda y no del edificio (habrán de excluirse los portales, pasillos y demás dependencias comunes).

Respecto a la agravatoria de asalto a tren, buque, aeronave, automóvil u otro vehículo, dada su naturaleza, sólo cabría apreciarla en el robo violento, y no en el cometido con fuerza en las cosas, para el que especialmente está previsto. Su escasa incidencia nos hizo aconsejar al legislador su supresión.

Otro tanto cabe decir de la cuarta de las agravaciones, en su segundo miembro (asalto a la persona que custodia o tansporta caudales), exclusivamente estimable en el robo violento e intimidatorio. Sólo tendría el escaso juego que pudiera otorgarle la remisión que hace el inciso final del 105 del art. 501 del C. Penal. En el afán de establecer contornos conceptuales, en relación al primer miembro de la agravación, se detecta como nota esencial, la primordial dedicación del establecimiento a la conservación o custodia de caudales.

En la siguiente circunstancia (cometer el robo en edificio público y sus dependencias), cuya razón de agravar estriba en una especie de "desacato local", se trata de poner límites al concepto de edificio de titularidad pública, destacando la innecesariedad de que se halle abierto al público.

Dentro de las agravantes comunes con el hurto, en la de recaer sobre cosas destinadas al servicio público, con grave perturbación del mismo, o de cosas de primera necesidad, con grave desabastecimiento, se analiza la problemática que origina la relatividad del concepto; por otra parte, difícilmente captable por el dolo del autor. Es examinada y criticada la colisión que provoca con la figura delictiva de los desórdenes públicos, de análogas características (art. 249-2 C.P.).

La circunstancia caracterizada por el objeto de la sustracción (cosas de valor histórico, artístico o cultural) plantea, como principal cuestión, y que la tesis trata de dilucidar con argumentos, si la conceptuación de los objetos de arte debe hacerse con criterios formales o materiales (cosa de arte es la catalogada como tal por la Administración, o la que realmente lo sea, conforme a una noción material).

Una de las más originales circunstancias es la de "cuantía de notoria importancia", que constituye una esperada innovación en el seno de nuestro derecho positivo, 
al arrumbar con los criterios de castigo de los delitos patrimoniales, a través de los escalonamientos cuánticos. El peligro de la misma estribaría en el excesivo arbitrio judicial otorgado. En principio, podría atenuarse con la unificación de criterios, operada por el Tibunal Supremo. Mas, a partir de la Ley Orgánica de 28 de Diciembre de 1988, con la creación de los Juzgados de lo Penal, la diversidad de criterios resolutivos ha de ser la nota dominante.

$\mathrm{Y}$ por fin, la última de las circunstancias, integrada por el ocasionamiento de una grave situación económica a la víctima o a su familia, además de su carácter igualmente relativo, porpugnamos la fusión con la precedente. La última parte de la agravación (abuso de superioridad), se considera inoperante y abogamos por su desaparición de lo que pueda ser el nuevo Código Penal.

Como capítulo aparte y después de estudiar las circunstancias una por una, se examina la incidencia de éstas, en algunos de los aspectos más destacados de la vida jurídica del delito, y de la pena (repercusión en autores, cómplices, y encubridores, comunicabilidad a los copartícipes, la posibilidad de la continuidad delictiva, entre las diversas cualificaciones, etc.). 
